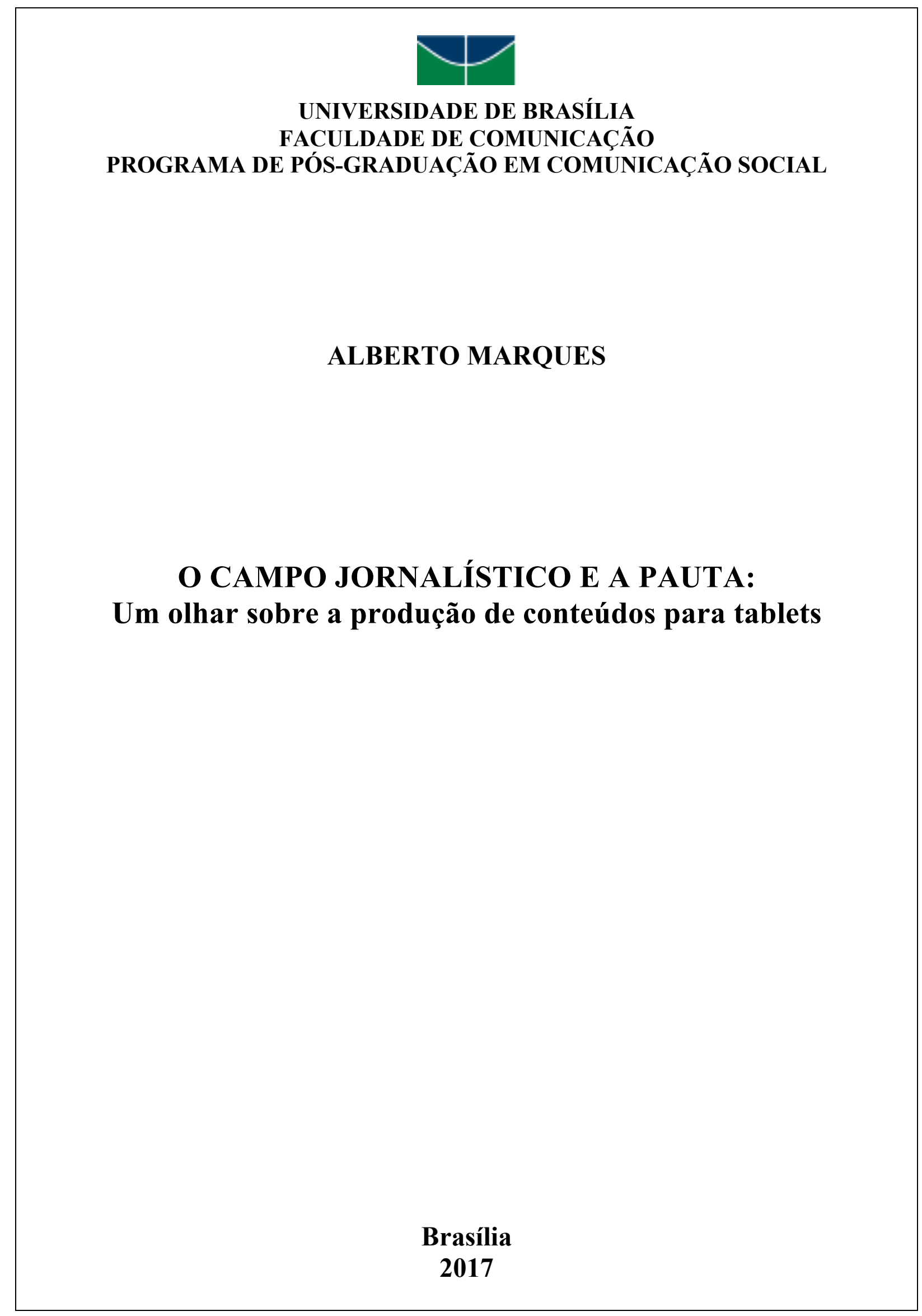




\section{ALBERTO MARQUES}

\section{O CAMPO JORNALÍSTICO E A PAUTA: Um olhar sobre a produção de conteúdos para tablets}

Tese apresentada ao Programa de Pós-Graduação em Comunicação Social da Faculdade de Comunicação da Universidade de Brasília como requisito parcial para a obtenção do título de Doutor em Comunicação.

Orientadora: Prof $^{a}$. Dr ${ }^{a}$. Thaís de Mendonça Jorge

Brasília

2017 
Marques, Alberto

MAL334 O campo jornalístico e a pauta: um olhar sobre a produção de conteúdos para tablets / Alberto Marques; orientadora Thais de Mendonça Jorge. -- Brasília, 2017.

$290 \mathrm{p}$.

Tese (Doutorado - Doutorado em Comunicação) -Universidade de Brasília, 2017.

1. Pauta. 2. Tablets. 3. Rotinas produtivas. 4. Tabletjornalismo. I. Jorge, Thais de Mendonça, orient. II. Título. 


\title{
O CAMPO JORNALÍSTICO E A PAUTA: Um olhar sobre a produção de conteúdos para tablets
}

Tese apresentada ao Programa de Pós-Graduação em Comunicação Social da Faculdade de Comunicação da Universidade de Brasília como requisito parcial para a obtenção do título de Doutor em Comunicação.

Brasília, 03 de fevereiro de 2017.

\section{BANCA EXAMINADORA}

\author{
Prof $^{\mathrm{a}}$. Dr ${ }^{\mathrm{a}}$. ThAis DE MENDONÇA JORGE (Presidente) \\ Programa de Pós-Graduação em Comunicação Social - UnB \\ $\operatorname{Prof}^{\mathrm{a}}$. Dr ${ }^{\mathrm{a}}$. CARLA ANDREA SCHWINGEL (Examinadora externa) \\ Prof $^{a}$. Dr ${ }^{\mathrm{a}}$. SOFIA CAVALCANTI ZANFORLIN (Examinadora externa) \\ Programa de Pós-Graduação em Comunicação Social - UCB \\ Prof $^{\mathrm{a}}$. Dr ${ }^{\mathrm{a}}$. ANA CAROLINA KALUME MARANHÃo (Examinadora) \\ Faculdade de Comunicação - UnB
}

Prof. Dr. TIAGo QuiRoga (Examinador)

Programa de Pós-Graduação em Comunicação Social - UnB

Prof $^{\mathrm{a}}$. Dr ${ }^{\mathrm{a}}$. JANARA SOUSA (Suplente)

Programa de Pós-Graduação em Comunicação Social - UnB 
Um dia, quem sabe, ela, que também gostava de bichos,

apareça

numa alameda do zôo, sorridente,

tal como agora está no retrato sobre a mesa. Ela é tão bela, que, por certo, hão de ressuscitá-la.

Vosso Trigésimo Século ultrapassará o exame de mil nadas, que dilaceravam o coração. Então, de todo amor não terminado seremos pagos em inumeráveis noites de estrelas. Ressuscita-me, nem que seja só porque te esperava como um poeta, repelindo o absurdo quotidiano! Ressuscita-me, nem que seja só por isso! Ressuscita-me!

Quero viver até o fim o que me cabe! Para que o amor não seja mais escravo de casamentos, concupiscência, salários.

Para que, maldizendo os leitos, saltando dos coxins, o amor se vá pelo universo inteiro.

Para que o dia, que o sofrimento degrada, não vos seja chorado, mendigado.

E que, ao primeiro apelo:

- Camaradas!

Atenta se volte a terra inteira.

Para viver

livre dos nichos das casas.

Para que doravante a família seja o pai,

pelo menos o Universo, a mãe, pelo menos a Terra.

Vladimir Maiakovski (1893-1930) 


\section{AGRADECIMENTOS}

A vida é cheia de caminhos e, durante este percurso, deparamo-nos com diversos momentos que serão reflexos de escolhas. Das nossas, dos nossos entes, das pessoas que estão a nossa volta. Conscientes ou não, esses caminhos nos possibilitam chegar a locais em que nos encontramos.

O meu local de fala é de um estudante de doutorado que teve a sorte de encontrar com pessoas que remediaram o agora. A ordem desses encontros certamente é reflexo dessas escolhas emaranhadas, mas não diminui o grau de importância, nem dá significação diferente ao agora.

Primeiro a minha esposa, Fabíola Araújo, por lidar com parcimônia, companheirismo, colaboração e compreensão em um momento tão árduo da vida. Falar dela é também falar do nosso filho Gabriel, que veio ao mundo justamente na etapa final da tese. A vocês, ao meu lado, dias mais afetuosos e cheios de amor.

A minha orientadora, Thais de Mendonça Jorge, que foi generosa e compreensiva, e contribuiu de forma decisiva para que o trabalho avançasse e chegasse ao final. As limitações deste trabalho certamente são de responsabilidade minha, durante o processo de construção desta tese.

Ao Programa de Pós-graduação em Comunicação Social da Universidade de Brasília, que me acolheu e me ofereceu ensinamentos valiosos na minha jornada. Desejo que este modelo de instituição perdure por muitos anos e que outros estudantes, cidadãos como eu, tenham a oportunidade de ocupar o mesmo espaço.

À Capes, pela bolsa de estudos e pela possibilidade de fazer o doutoramento sanduíche. Há sem dúvida uma dívida e um ganho incomensurável nesse processo: o conhecimento adquirido, bem como o sentimento de gratidão ao Estado. Sem esse apoio certamente a conclusão desse processo seria mais difícil.

Aos meus pais: Zilná Marques Silva e José Alberto Xavier O. Silva (in memoriam). O tempo nos mostra o quanto aprendemos com eles e o quanto eles são fundamentais no processo de formação.

Aos meus sogros, Dalci Souza Araújo e José Gerardo Araújo, por me acolherem e ajudarem neste momento difícil. São exemplos de abnegação e bem-querer para muitos seres, dedicando sempre o seu melhor. 
E, por fim, aos meus amigos e familiares. Cada um com suas particulares e cheios de significados a acrescentarem ao meu viver e, consequentemente, ao trabalho. Vocês também são fundamentais na minha vida. Aprendi e aprendo incontestavelmente com vocês. 
MARQUES, Alberto. O campo jornalístico e a pauta: um olhar sobre a produção de conteúdos para tablets. 290 f. 2017. Tese (Doutorado) - Faculdade de Comunicação, Universidade de Brasília, Brasília, 2017.

\section{RESUMO}

O jornalismo digital, aliado à convergência jornalística e ao desenvolvimento de versões jornalísticas para tablets, chamado nessa tese de tabletjornalismo, tem gerado inúmeras transformações nas rotinas produtivas dos jornalistas. Historicamente, desde que o jornalismo virou uma atividade comercial, a pauta tem sido elemento importante nas práticas de construção de edições jornalísticas. É ela que condiciona o que circulará nos jornais, ou seja, aquilo a que a audiência terá acesso. O problema de pesquisa gira em torno das transformações provocadas no processo de produção jornalística para tablets no âmbito da convergência jornalística. Com isso, partimos da hipótese balizadora de que a inserção das versões para tablets nas redações proporciona transformações na produção da pauta, com repercussão nos processos de produção, edição e distribuição dos conteúdos É neste cenário de transformações que esta tese busca investigar quais dos elementos que compõem a pauta de uma edição jornalística são alterados quando feitos para tablets. Como método de pesquisa, utilizamos algumas estratégias; primeiro a proposta bourdieusiana estruturalistaconstrutivista. É com esse olhar que adotamos a proposta do Grupo de Pesquisa em Jornalismo Online (GJOL) como estratégia de pesquisa. Aplicamos no nosso corpus de pesquisa, Zero Hora Noite, Diário do Nordeste Plus e O Globo A Mais, observações participantes e entrevistas com membros da redação. Embasados nos resultados alcançados, confirmamos nossa hipótese: a pauta pensada para tablets sofre alterações, embora a mudança em suas características dependa do formato organizativo das redações.

Palavras-chave: Pauta; tablets; rotinas produtivas; tabletjornalismo. 
MARQUES, Alberto. The journalistic field and the assignment: a look at the production of contents for tablets. 290 pp. 2017. Tesis (PhD.) - University of Brasília Social Comunication School, Brasília, 2017.

\begin{abstract}
Digital journalism, coupled with journalistic convergence and the development of journalistic versions for tablets, referred to in this thesis as tabletjournalism, has generated numerous transformations in the productive routines of journalists. Historically, since journalism has become a commercial activity, the task assignment has been an important element in the construction of journalistic issues. The assignment decisions condition what themes circulate in the newspapers, that is, what the audience will have access to. The research problem revolves around the transformations provoked in the process of journalistic production for tablets within the scope of journalistic convergence. With this, we start from the hypothesis that the insertion of tablet editions in the newsrooms provides transformations in the assignments, with repercussion in the processes of production, edition and distribution of the contents. It is in this scenario of transformations that this thesis seeks to investigate which of the elements that compose the guidelines of a journalistic edition changed when made for tablets. As a research method, we use some strategies; first, the structuralist-constructivist bourdieusian proposal. It is with this look that we adopted the proposal of the Group of Research in Online Journalism (GJOL) as a research strategy. We applied participative observations and interviews with members of the editorial staff to our research corpus, Zero Hora Noite, Diário do Nordeste Plus and O Globo A Mais. Based on the results achieved, we confirm our hypothesis: the guidelines for tablet editions undergoes through changes, although the variance in their characteristics depends on the organizational format of the newsrooms.
\end{abstract}

Keywords: task assignment; tablets; production routines; tabletjournalism. 


\section{LISTA DE ILUSTRAÇÕES}

TABELA 1 - Aplicativos de jornais divididos por região (produção nossa) 72

TABELA 2 - Aplicativos de jornais divididos por região (produção nossa) 74

TABELA 3 - Entrevistas feitas nas redações (produção nossa) 99

GRÁFICO 1 - Modelo de White sobre gatekeeper. (MCQUAIL, WINDAHL, 1993, p. 166) ...37

GRÁFICO 2 - Modelo organizacional proposto por Westley e Maclean (1957, p. 35) 39

GRÁFICO 3 - O modelo de fluxo de informações internacionais (MCNELLY, 1959, p. 25) .. 40

GRÁFICO 4 - Coletores e processadores de noíticias: indivíduos mais importantes no processo de gatekeeping (BASS, 1969, p. 62)

GRÁFICO 5 - O processo interno ou a descrição da microssocilogia do newsmaking. Fonte: (ERICSON, BARANEK, CHAN 1987, p. 98) …........................................... 53

GRÁFICO 6 - Modelo Macrossociológico (TUCHMAN, 2002, p. 80) …................................ 58

GRÁFICO 7 - A pauta está no centro do processo de produção (produção nossa) ................... 75

GRÁFICO 8 - Tipos de pautas e suas divisões (produção nossa) .............................................. 88

GRÁFICO 9 - Passos dados para produção do O Globo A Mais (produção nossa) ................... 107

GRÁFICO 10 - Fluxo de produção circular do Globo A Mais (produção nossa) ..................... 115

GRÁFICO 11 - Fluxo de produção circular do Zero Hora (produção nossa) ............................. 129

GRÁFICO 12 - Fluxo de produção circular do Diário do Nordeste (produção nossa) ............... 133

GRÁFICO 13 - Fluxo de produção do Diário do Nordeste Plus (produção nossa) .................... 138

GRÁFICO 14 - Quatro níveis de seleção da informação no processo de produção (produção nossa) 


\section{LISTA DE IMAGENS}

IMAGEM 1 - Mesa central da redação do Zero Hora (produção nossa) 


\section{Capítulo I - O ESTRUTURALISMO CONSTRUTIVISTA E O CAMPO

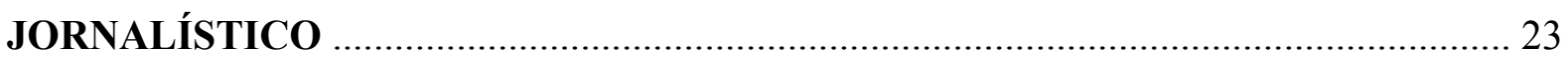

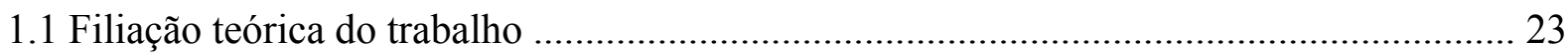

Capítulo II - A FORMAÇÃO DO CAMPO JORNALÍSTICO: DO GATEKEEPER AO

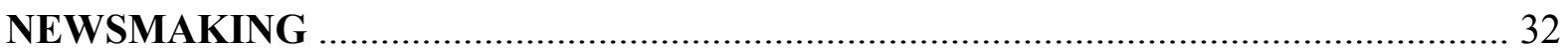

2.1 A expansão da imprensa e a consolidação das rotinas jornalísticas ................................ 32

2.2 Do gatekeeping ao newsmaking: desenvolvimento das teorias ...................................... 36

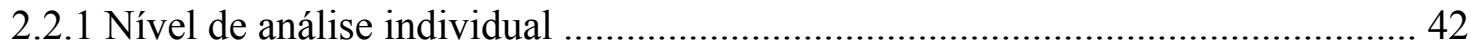

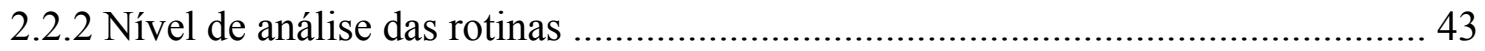

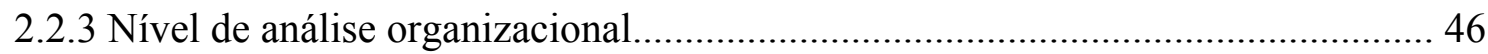

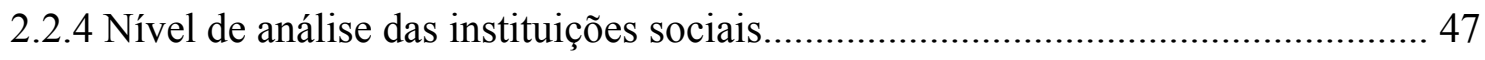

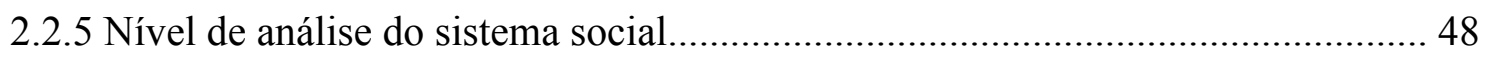

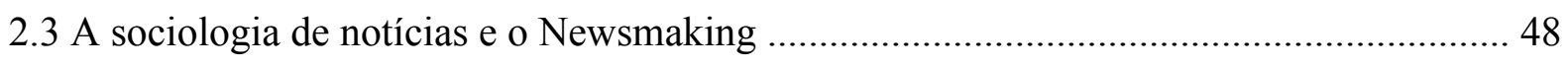

Capítulo III - CONVERGÊNCIA JORNALÍSTICA E AS TRANSFORMAÇÕES DE

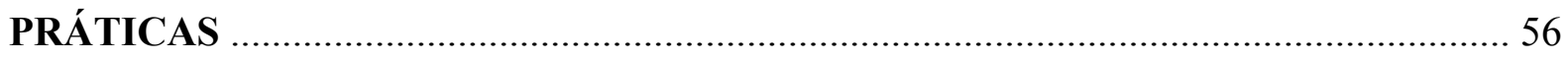

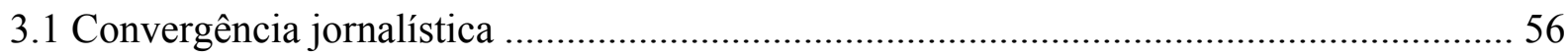

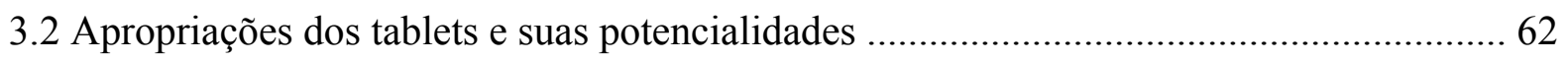

3.2.1 Mapeando a realidade brasileira: da expansão ao declínio .................................6 64

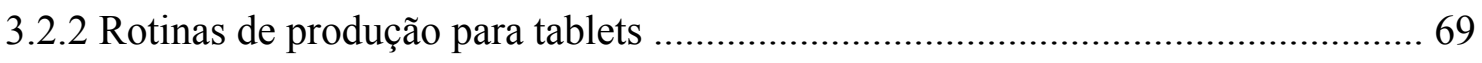

Capítulo IV - A EVOLUÇÃO DA PAUTA E SEUS ASPECTOS ................................. 74

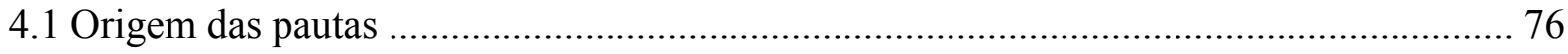

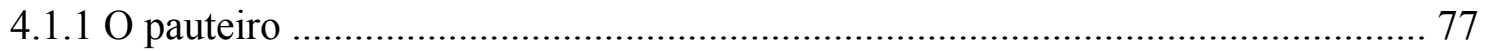

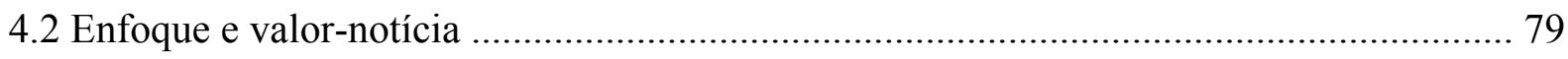

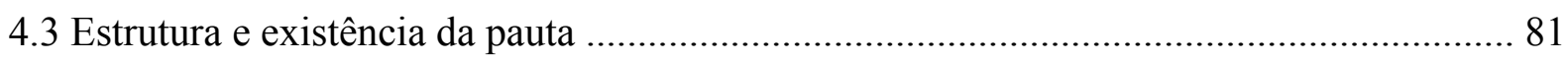

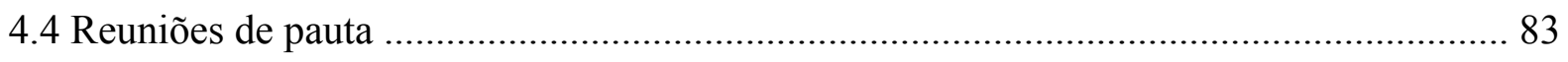

4.4.1 Cruzamento de culturas profisssionais: da pauta à circulação ............................ 86

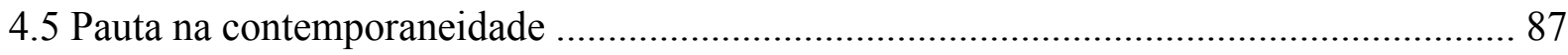




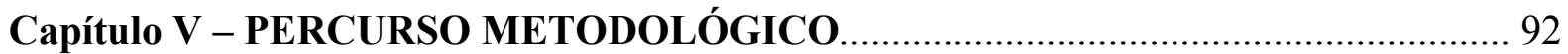

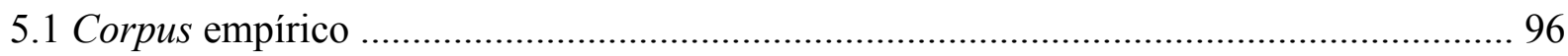

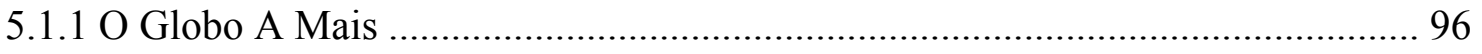

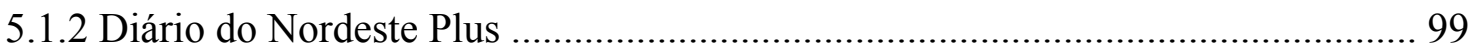

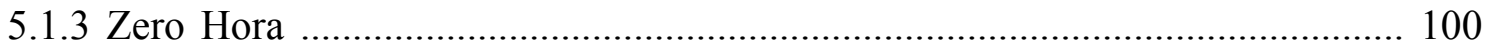

\section{Capítulo VI - A CONVERGÊNCIA JORNALÍSTICA: UM OLHAR SOBRE A PAUTA} COM FOCO NA INTRODUÇÃO DOS TABLETS NAS REDAÇÕES DIGITAIS .... 102

6.1 Rotinas produtivas para tablets: a experiência de O Globo A Mais ............................... 102

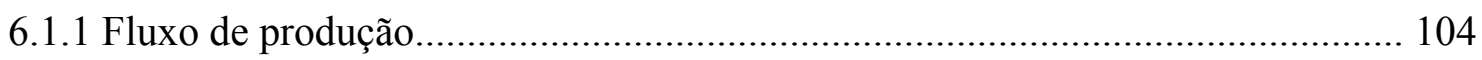

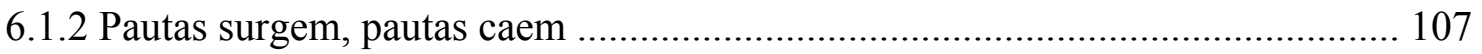

6.1.3 A produção multimídia para tablets ................................................................. 109

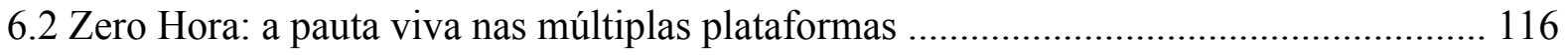

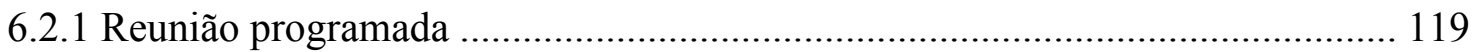

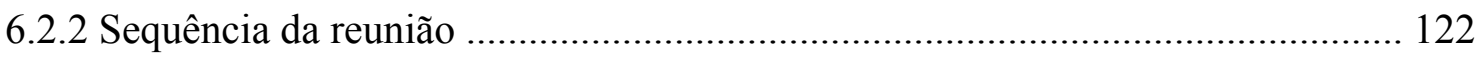

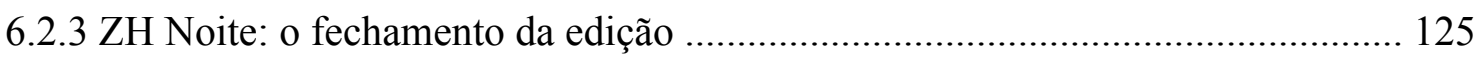

6.2.4 A terceira reunião: o fechamento e a preparação do próximo dia ...................... 127

6.3 Diário Do Nordeste: a pauta e os processos produtivos .............................................. 130

6.3.1 Diário Do Nordeste Plus: de aplicativo a página web ....................................... 134

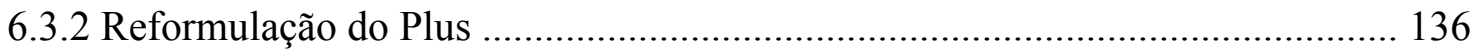

6.4 Os portões nos meios de comunicação e a importância da pauta ..................................... 140

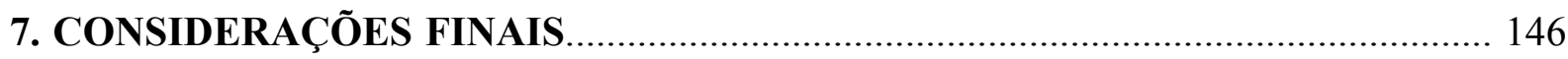

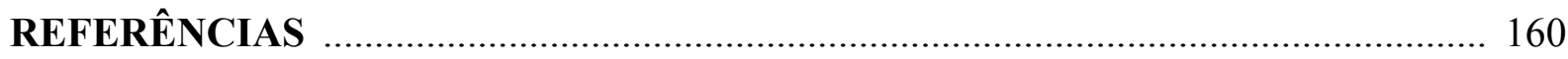

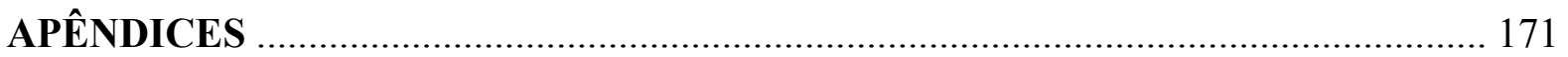

Apêndice A - Formulário de entrevista com os editores de O Globo A Mais ...................... 172

Apêndice B - Formulário de entrevista com os repórteres de Globo A Mais .................... 175

Apêndice C - Formulário de entrevista com o editor de multimídia de O Globo A Mais ... 177

Apêndice D - Entrevista com Repórter 1 de O Globo A Mais ............................................. 178

Apêndice E - Entrevista com Repórter 2 de O Globo A Mais .............................................. 181

Apêndice F - Entrevista com Repórter 3 de O Globo A Mais .............................................. 187 
Apêndice G - Entrevista com Repórter 4 de O Globo A Mais .............................................. 192

Apêndice H - Entrevista com Repórter 5 de O Globo A Mais ............................................ 196

Apêndice I - Entrevista com Repórter 6 de O Globo A Mais ........................................... 202

Apêndice J - Editor 1 de O Globo A Mais ...................................................................... 205

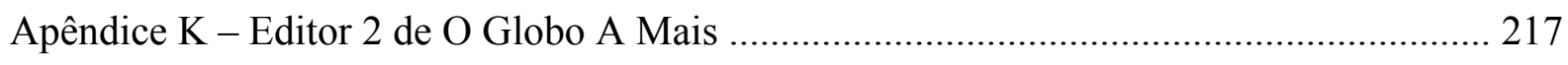

Apêndice L - Editor 3 de O Globo A Mais ......................................................................... 226

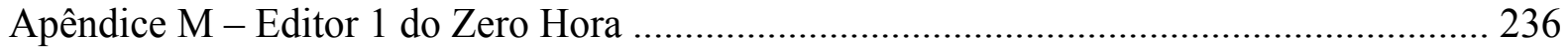

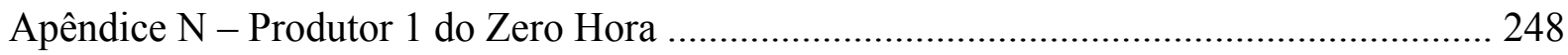

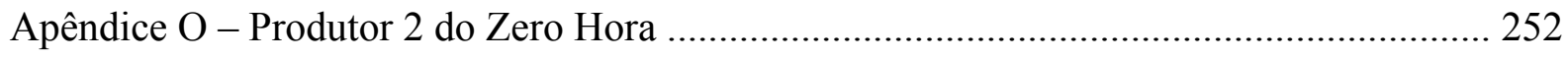

Apêndice P - Repórter 1 do Zero Hora Noite ....................................................................... 258

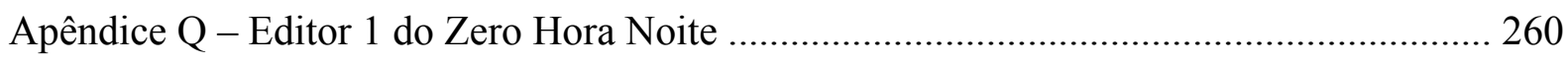

Apêndice R - Programador do Zero Hora ...................................................................... 263

Apêndice S - Editor-Geral do Diário do Nordeste Plus ................................................... 264

Apêndice T - Editora Executiva Digital do Diário do Nordeste .......................................... 266

Apêndice U - Editor Executivo do Diário do Nordeste ........................................................ 268

Apêndice V - Editor do Diário do Nordeste Plus ............................................................. 270

Apêndice W - Repórter do Diário do Nordeste Plus ........................................................... 273

Apêndice X - Editor do Diário do Nordeste Plus - entrevista feita em 23/03/2015 - antes das

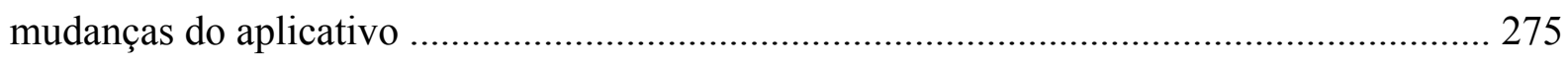

Apêndice Y - Repórter do Diário do Nordeste Plus - entrevista feita em 23/03/2015 - antes

das mudanças do aplicativo

Apêndice Z - Editora Assistente do Diário do Nordeste Plus - entrevista feita em 23/03/2015

- antes das mudanças do aplicativo 


\section{INTRODUÇÃO}

A pauta jornalística é o elemento central no processo de produção desde que a profissão virou atividade econômica e passou a ganhar reconhecimento social. Seu desenvolvimento se dá no âmbito das transformações dos séculos XIX e XX como períodos que provocaram mudanças profundas e deram forma ao jornalismo moderno (ROSHCO, 1975; GENRO FILHO, 1987; CHALABY, 1996; TRAQUINA, 2002; SCHUDSON, 2010). Essas alterações aconteceram, principalmente, no Estados Unidos e, em menor grau, na Inglaterra (CHALABY, 1996, p. 304) e são marcadas pelas "interferências" econômicas, sociais e tecnológicas da época. O Brasil passou a signatário desse modelo anglo-americano.

A partir desses processos, a elaboração da pauta transforma-se em um elemento comum nos diversos meios de comunicação jornalísticos. Sua criação dá ordem ao caos no mundo dos fatos e possibilita que esses episódios recebam tratamento jornalístico de forma sistemática (BERNARDES, 2003). É importante destacar que a pauta é introduzida ao mesmo tempo em que despontam as novas técnicas de redação, a programação gráfica das páginas e os procedimentos gerenciais que deram feição à imprensa moderna (LAGE, 2001).

É justamente com a sistematização das práticas e consolidação das empresas jornalísticas que se criou um grupo profissional assalariado, que buscava sua remuneração a partir da originalidade das informações. Essa originalidade perpassa indubitavelmente pela pauta. Um racionalização que "reforça uma habilidade profissional à base de técnicas, de capacidade de investigação, de uma escrita normatizada[...]” (NEVEU, 2006, p. 26).

Como foco principal, esta tese se debruça sobre a pauta como elemento central no processo de produção jornalística para tablets. Como conceito operacional deste trabalho, partimos da compreensão da pauta como roteiro ou agenda - oral ou escrita - dos principais assuntos a serem abordados na edição de um meio de comunicação noticioso (LUZ, 2005b) e que perpassa todo o processo produtivo. Com isso, afirmamos que ela não é uma etapa estanque do processo de produção. Ela permeia todas as etapas de produção e edição de notícias e vai evoluindo durante todo o desenrolar do trabalho de uma equipe jornalística, até desembocar na circulação do produto final.

A opção pelo estudo da pauta nesta pesquisa se dá principalmente pelo escasso volume de pesquisa sobre a temática. Em julho de 2015, empreendemos uma busca nos repositórios dos programas de pós-graduação em comunicação filiados à Compós (Associação 
Nacional dos Programas de Pós-Graduação em Comunicação) e somente encontramos uma tese de doutorado (LUZ, 2005a) e uma dissertação de mestrado (OBLIZINER, 1997).

“O lugar da pauta é tão definidor no processo de produção da notícia que causa estranheza não encontrarmos reflexões a respeito do assunto.” (LUZ, 2005b, p.99). Passados 12 anos da afirmação da pesquisadora, destacamos que a carência ainda persiste e que são raros os trabalhos acadêmicos sobre o tema, sejam teses, dissertações, monografias, artigos em periódicos e congressos.

Há uma inquietação que subjaz todo esse questionamento: a pauta ainda é um documento importante nas rotinas produtivas de uma redação convergente, em especial na redação de informativos para tablets? O questionamento nasce justamente a partir de diversas transformações que a profissão tem passado. A digitalização da informação e o desenvolvimento da microinformática e da internet estão entre os fatores preponderantes dessa transformação.

Nos anos 1980, Gomes (2009) previa que a rápida expansão do uso dos computadores, a par da proliferação de diversos tipos de bases de dados eletrônicos, transformaria consideravelmente a forma como os jornalistas recolheriam os dados e formulariam a notícia. "Todas as etapas, incluindo a coleta, o processamento e a transmissão de conteúdos informativos passaram por uma reformulação [...]”. Esse processo está diluído em diversos instantes na história da comunicação (JORGE, 2007, p. 61). Todas essas transformações exigem do jornalismo novas formas de organização (DEUZE e WITSCHGE, 2015; SATUF, 2016).

$\mathrm{Na}$ contemporaneidade, há quem defenda que o jornalismo está saindo da fase industrial, narrada no começo dessa introdução e melhor desenvolvida no capítulo II desta tese, para um momento conhecido como jornalismo pós-industrial (ANDERSON, BELL, SHIRKY, 2013). A proposta é nova e está em construção. Um dos aspectos deflagradores desse processo é a multiplicação de canais de produção noticiosa e informativa (ADGHIRNI; JORGE, 2011), antes restrita apenas a um pequeno conjunto de atores (ANDERSON, BELL, SHIRKY, 2013). É em um cenário de crise (ROBINSON, 2011), deflagrado também por essas transformações mencionadas neste ponto, que as empresas de mídia buscam incessantemente por inovações, capazes de conferir menores custos de produção e mais celeridade, com foco em aumentar a rentabilidade e a competitividade dos grupos de comunicação.

Atentos aos processos em transformação, buscamos aporte teórico em algumas corretes de estudo. A primeiro está no âmbito do jornalismo digital. Essa prática jornalística 
privilegia os meios tecnológicos utilizados na instância da produção ou na de disseminação de informações (MIELNICZUK, 2003, p. 24). A tecnologia digital nesse tipo de método é utilizada para todo e qualquer procedimento que implica no tratamento de dados em forma de bits. Como frisamos no capítulo III, na contemporaneidade, praticamente todo jornalismo é digital.

Uma das características mais marcantes do jornalismo digital é o fenômeno de convergência jornalística, que se traduz na criação de novos formatos de narrativas e integração de redações. A convergência jornalística (DOMINGO et al, 2007; SALAVERRÍA, GARCÍA AVILÉS et al, 2007; GARCÍA AVILÉS, MASIP, 2008, 2010; SALAVERRÍA, NEGREDO, 2008) é entendida como um processo de junção das redações, que afeta as esferas Tecnológica, Profissional, Empresarial e Editorial/Conteúdo dos meios de comunicação. Este processo desencadeia a junção de ferramentas, espaços, rotinas de trabalho e linguagens. Há, neste contexto, uma produção de conteúdos para que sejam distribuídos mediante múltiplas plataformas, por meio das linguagens próprias a cada uma delas.

É o momento também em que são empregados bases de dados, algoritmos, linguagens de programação, metadados semânticos, softwares, técnicas de visualização, entre outros no jornalismo. Trata-se de um ambiente midiático múltiplo. Nele estão inseridos os dispositivos móveis, como smartphones e tablets. Neste fenômeno existe uma atuação conjunta e integrada entre os meios (SALAVERRÍA e NEGREDO, 2008), com distintos fluxos de produção, edição e distribuição de conteúdo. Esses aspectos vão caracterizar o continuum multimídia de cariz dinâmico (BARBOSA, 2009a). Este aporte delimita um estágio pelo qual o jornalismo digital passa.

Essa lógica também pode ser compreendida pela perspectiva da medialidade, proposta por Grusin (2010, p. 6). Nessa dialética, a produção jornalística seria realizada por profissionais que se utilizam de tecnologias digitais em todos os processos de produção jornalística nas redações, e também pela horizontalidade de produção e conteúdo. O ponto principal desse conceito é que não há mais oposição entre novos e velhos meios. Complementando a ideia de convergência, a ideia do 'novo' é rompida, bem como a ideia de concorrência entre os meios que integram um mesmo grupo jornalístico (BARBOSA, 2013).

Sobre os tablets, objeto também desta pesquisa, seu marco da inserção no mercado é o mês de abril de 2010 quando a Apple lançou o iPad (CANAVILHAS; DE SANTANA, 2011). Apesar de não serem novidade no mercado da tecnologia, o lançamento de Steve Jobs representou o boom de vendas e aceitação do aparelho no mercado mundial. A prática jornalística é anterior ao lançamento da Apple, com o 'tablet newspaper' há 17 anos, em 
1997. O professor e diretor do programa Digital Publishing Donald W. Reynolds Journalism, da Universidade do Missouri (EUA), Roger Fidler, é o idealizador do dispositivo (BARBOSA, SEIXAS, 2013).

O jornalismo feito para esse tipo de plataforma também pode ser chamado de tabletjornalismo (CUNHA e FREIRE, 2017, NO PRELO). A proposta dos autores é interessante, contudo, limitadora. Os pesquisadores acreditam que o termo é designado somente para os produtos autóctones ${ }^{1}$. Contudo, apesar de compreendermos que se trata de um modelo ideal, entendemos que outras apropriações do suporte devem ser chamadas dessa forma, principalmente porque seria restritivo impor um padrão de apropriação. A proposta segue a mesma lógica do webjornalismo, telejornalismo ou radiojornalismo.

Para a realização da pesquisa e exploração de uma temática que entrelaça o antigo com o novo, direcionamos a pesquisa a três estudos de caso (YIN, 2005) empíricos - Globo A Mais, Zero Hora Noite e Diário do Nordeste Plus. Fizemos observações diretas in loco e na recuperação das experiências como o trabalho se constitui e quais aspectos incidem sobre a produção jornalística considerando dois conceitos-base: convergência e mobilidade. Logo, a perspectiva multiplataforma é levada em consideração na exploração desse corpus e o atravessa. Entrevistas estruturadas e semiestruturadas também foram realizadas.

Para efeitos de delimitação do termo jornalismo, nesta tese, quando nos referimos à palavra, estamos falando sobre o conjunto ou a globalidade de um fenômeno, que abarca o jornalismo como instituição e como atividade prática. "A 'instituição jornalística' está relacionada ao aspecto coletivo e organizacional do jornalismo, [...], que aglutina, organiza e dá unidade a normas de ação e valores culturais institucionalizados". Com isso, estamos dizendo que a atividade jornalística está relacionada ao conjunto das práticas, normas, valores e conhecimentos que orientam os jornalistas em seu dia a dia. (FRANCISCATO, 2003, p. 22).

Apesar de integrarem o corpo coletivo, são os jornalistas, os agentes do campo (BOURDIEU, 1998), que possibilitam que a atividade seja um conjunto dinâmico de conhecimentos. Essas práticas são recriadas durante o exercício da profissão (FRANCISCATO, 2003). E é esse conjunto que possibilita a maneira de perceber, julgar e valorizar o mundo. É ele que aperfeiçoa a nossa forma de agir no dia a dia e que vai condicionar nosso princípio de ação, permitindo a observação das práticas classificáveis a partir de estruturas mentais. Trata-se de algo que se constrói e se modifica historicamente, e que, na essência, é um produto da interiorização das práticas sociais (BOURDIEU, 1998),

\footnotetext{
${ }^{1}$ Versões autóctones nascem exclusivamente para o suporte, possuem equipe própria e uma produção exclusiva.
} 
vinculadas a um tempo e espaço social específico, possibilitando a incorporação dos atores sociais (agentes) às regras do campo.

Com essas explicações, achamos apropriada para o nosso trabalho a proposta teóricametodológica de Bourdieu (1998) chamada de "estruturalista construtivista" (structuralist constructivism) ou "estruturalismo genético", explicada no primeiro capítulo dessa tese. Essa corrente de pesquisa propõe a existência de estruturas objetivas, independentes da consciência e da vontade dos agentes e sustenta que elas são produto de uma gênese social dos esquemas de percepção, de pensamento e de ação. Existe, nesse contexto, um contínuo na construção das estruturas, das representações e das práticas (THIRY-CHERQUES, 2006).

O pensamento de Bourdieu (1998) vai se diferenciar por conferir grande importância à observação da prática dos agentes, bem como o interesse pelos diversos fenômenos sociais, não se restringindo somente às relações de coerção que esses agentes impõem. $\mathrm{O}$ autor refuta também o determinismo e a estabilidade das estruturas e entende que as ações, mesmo as mais pessoais, não pertencem ao sujeito e sim "[...] ao sistema completo de relações nas quais e pelas quais elas se realizam” (THIRY-CHERQUES, 2006, p. 29). Contudo, isso não quer dizer que as práticas individuais não sejam importante.

Isso é importante ao refletirmos sobre as rotinas produtivas e nos ajudou nas observações in loco. Uma pesquisa que considere os critérios da teoria estabelecida por Bourdieu (1998) tem por objetivo identificar as estruturas, tanto as que regem as relações de um determinado segmento social (estruturantes do campo) quanto as que são estabelecidas por estas relações sociais (estruturadas, portanto).

Mais um ponto teórico que utilizamos em nossa tese é o processo do gatekeeper ${ }^{2}$, uma das mais antigas teorias a ter como objeto de pesquisa o jornalismo (ALSINA, 2009). Seu desenvolvimento se dá a partir do estudo seminal de White (1950) e se aprimora com outros pesquisadores (MCNELLY, 1959; BASS, 1969; CHIBNALL, 1977; GANDY, 1982) que acrescentaram novos elementos à teoria.

Gatekeeping é entendido neste trabalho como o processo de seleção e processamento de vários pedaços de informação em mensagens que chegam aos receptores (SHOEMAKER, VOS, 2011). Destacamos que o processo determina não somente qual informação será escolhida, mas também qual será o conteúdo (fontes, angulação e hierarquização) e a natureza

\footnotetext{
${ }^{2} \mathrm{O}$ termo é utilizado tanto para definir o selecionador, quem seleciona a informação que cruza os portões dos meios de comunicação, como pode ser usado para se referir a teoria, hoje entendida como mais ampla que a seleção.
} 
(gênero e formato) das mensagens. Pontos que estão em conformidade com a pauta jornalística, o principal aspecto das rotinas produtivas, foco deste trabalho.

Para o nosso trabalho, interessa-nos a tipologia desenvolvida por Pamela Shoemaker (1991) e seu trabalho em parceria com Reese (1996), que propõem uma visão abrangente do gatekeeping, mostrando que, por trás do processo, existe também um sistema social, um controle ideológico e cultural, o que nos aproxima mais do debate teórico-metodológico proposto no primeiro capítulo de Bourdieu (1998).

Utilizamos os cinco níveis para o estudo do gatekeeping em contextos contemporâneos para compreender a construção da pauta: o dos profissionais da comunicação individuais; o das rotinas ou práticas do trabalho em comunicação; o nível organizacional; o nível de análise sócio-institucional; e o nível do sistema social (SHOEMAKER , 1991; SHOEMAKER e MAYFIELD, 1987; SHOEMAKER e REESE, 1996, SHOEMAKER e VOS 2011). Esses pontos são explicados no capítulo II da tese. Acreditamos, apesar de não ser o seu objetivo, que os agentes que produzem e participam do processo de produção do item jornalístico, submetem-se aos níveis propostos pelos autores.

Como se trata de um trabalho sobre rotinas produtivas, gatekeeping e newsmaking são teorias que estão atreladas ao nosso trabalho. Compreendemos que os estudos do gatekeeper são consolidadores de uma corrente mais ampla de pesquisa: o newsmaking. $\mathrm{O}$ que estamos propondo no trabalho é que o newsmaking e as investigações de gatekeeping estão inclusos nos estudos da sociologia dos emissores ou sociologia da produção de notícias (ROSCHO, 1975; VASQUÉS, 2003). Os exames desta perspectiva buscam identificar processos e práticas sociais, macrossociológicas e microssociológicas (GANS, 1979; TUCHMAN, 2002; SATUF, 2016), relacionados à produção das mensagens informativas feitas pelos jornalistas no contexto dos meios noticiosos. O sociólogo de notícias tem a preocupação com a gênese da notícia e não com suas consequências.

Depois dessa exposição de teorias que fazem parte da nossa tese, explicamos que proposta desta pesquisa nasce da análise empírica: ao observar as rotinas produtivas do Globo A Mais (MARQUES, 2015), identificamos que existiam transformações no processo de produção da pauta. A partir deste olhar, passamos a fazer uma revisão bibliográfica sobre o tema. Apesar de a pauta, no processo de produção da informação jornalística ter papel central e definidor dos temas tratados nas edições, nas pesquisas de jornalismo este é um assunto pouco abordado - como já frisamos. 
É neste cenário complexo que elaboramos nossas hipóteses. Elas nascem ao longo do trabalho, por meio da problematização da pesquisa, da observação preliminar do objeto pesquisado, da revisão de literatura e das reflexões em torno do tema. Nossas hipóteses são:

- Hipótese 1 - A inserção das versões para tablets nas redações proporciona transformações na produção da pauta, com repercussão nos processos de produção, edição e distribuição dos conteúdos;

- Hipótese 2 - A integração das redações transformam a pauta em um organismo vivo, em que seu conteúdo vai sendo adequado de acordo com as necessidades de cada suporte;

Vinculados às hipóteses estão nossos objetivos. Como objetivo geral, esta tese busca analisar e refletir sobre quais são e como os elementos que compõem a pauta de uma edição jornalística para tablets são transformados.

Como objetivos específicos, buscamos:

- Mapear, debater e refletir sobre o estado da arte do jornalismo feito para tablets no Brasil;

- Estruturar e identificar o processo de produção de uma edição para tablets;

- Elencar e analisar no contexto de uma redação convergente, quais elementos são levados em consideração para a construção de uma pauta;

- Refletir e especificar quais são os portões que a informação cruza para se tornar produto jornalístico para tablet.

Como organização do trabalho, no primeiro capítulo apresentamos a proposta metodológica de noção estruturalista construtivista (structuralist constructivism) de Pierre Bourdieu (1989, 2004, 1990, 1987). A ideia do ponto é dar suporte às estratégias metodológicas utilizadas no trabalho. Neste aspecto apresentamos conceitos operacionais do autor como campo, habitus, agentes, doxa e poder simbólico. Além das obras do pesquisador, Thiry-Cherques (2006), Vandenberghe (1999), Quiroga (2009) e Dortier (2002) foram fundamentais para a construção do capítulo.

O segundo capítulo apresenta a formação do jornalismo moderno, exibindo aspectos que marcaram a formação do campos jornalísticos e suas práticas (habitus). Nesse primeiro ponto, muitos autores (ROSHCO, 1975; GENRO FILHO, 1987; CHALABY, 1996; TRAQUINA, 2002; FRANCISCATO, 2003; SCHUDSON, 2010) foram fundamentais para construção do tópico. Com isso, debatemos o desenvolvimento da teorias inseridas na sociologia dos emissores ou, como alguns autores chamam, das notícias. Expomos também a 
pesquisa seminal (WHITE, 1950) do gatekeeper na comunicação até os primeiros estudos de newsmaking, como os de Warren Breed (1955) no segundo capítulo.

O terceiro capítulo teórico é sobre as tangentes entre a convergência (DOMINGO et al, 2007; SALAVERRÍA, GARCÍA AVILÉS et al, 2007; GARCÍA AVILÉS, MASIP, 2008, 2010; SALAVERRÍA, NEGREDO, 2008) e o continuum multimídia (BARBOSA, 2009a). Apresentamos também as potencialidades dos tablets e o jornalismo praticado para o veículo. Neste ponto também fazemos um mapeamento da situação dos aplicativos e o processo de transformação que esta modalidade de jornalismo sofreu ao logo da tese. Mostramos neste capítulo da ascensão à queda do dispositivo nos jornais brasileiros.

Por fim, e não menos importante, apresentamos o capítulo sobre pauta. A pauta cumpre duas funções principais (LAGE, 2001): uma função macro, organizando toda a edição, e uma função micro, organizando somente um assunto que será tratado na edição. Neste trabalho, nomeamos, respectivamente, pauta da edição (macro) e pauta de conteúdo (micro). Com isso, propomos que, para finns operacionais, a pauta de edição ou Pauta Macro seja dividida em convergente, geral e por editoria. O que chamamos Pauta Micro se refere a um único conteúdo.

Nossos resultados indicam que há alterações em curso no processo de produção de pauta para tablets, seja num cenário de uma redação convergente ou não. O ritmo frenético de produção para multiplataformas possibilita a transformação da pauta em um organismo vivo, reticular, que só é concretizada quando ela é transformada em um produto jornalístico e passa a circular para a audiência. 


\section{CAPÍTULO I}

\section{O ESTRUTURALISMO CONSTRUTIVISTA E O CAMPO JORNALÍSTICO}

Este capítulo apresentará os conceitos operacionais iniciais deste trabalho. Buscamos introduzir a proposta estruturalista construtivista do sociólogo Pierre Bourdieu como forma de nos trazer subsídios para a construção teórica e empírica do objeto de pesquisa desta tese. Procuramos, dessa forma, apresentar os conceitos da teoria que nos ajudarão no processo de construção metodológica do estudo, e servirão de orientação para a parte empírica. Como estamos nos debruçando sobre um dos aspectos do campo jornalístico, o aporte teórico forjará um olhar mais amplo à prática dos profissionais.

\subsection{FILIAÇÃO TEÓRICA DO TRABALHO}

Para a construção de nossa tese, apropriamo-nos da proposta teórica-metodológica chamada de "estruturalista construtivista" (structuralist constructivism) ou "estruturalismo genético" de Pierre Bourdieu (1998). Essa corrente de pesquisa propõe a existência de estruturas objetivas, independentes da consciência e da vontade dos agentes e sustenta que elas são produto de uma gênese social dos esquemas de percepção, de pensamento e de ação. Existe, nesse contexto, um contínuo na construção das estruturas, das representações e das práticas (THIRY-CHERQUES, 2006).

O estruturalismo bourdieusiano apresenta particularidades. Com o termo, o sociólogo quer dizer que existem no mundo social, e não apenas nos sistemas simbólicos (linguagem, mito, etc.), estruturas objetivas: os agentes são “[...] capazes de orientar ou coagir suas práticas e representações" (BOURDIEU, 1998, p. 149), o que não quer dizer que essas práticas e representações sejam sempre conscientes.

O pensamento de Bourdieu vai se diferenciar de outros pela importância que ele confere à observância da prática dos agentes e ao interesse pelos diversos fenômenos sociais, não se restringindo somente às relações de coerção que esses agentes impõem. Bourdieu prescinde do conceito de sujeito, ao empregar a ideia de agente. Para ele, à medida que atuam 
e que sabem, os indivíduos se tornam agentes, dotados de senso prático e de um sistema de preferências, classificações, e percepção que é adquirido (THIRY-CHERQUES, 2006).

$\mathrm{O}$ autor refuta também o determinismo e a estabilidade das estruturas e entende que as ações, sejam as mais pessoais, não pertencem ao sujeito e sim "[...] ao sistema completo de relações nas quais e pelas quais elas se realizam" (THIRY-CHERQUES, 2006, p. 29). Por meio dessa concepção, a posição de Bourdieu se distancia tanto do subjetivismo, o qual não considera que as condutas individuais também possuem uma origem social, quanto do estruturalismo, que refuta os aspectos relacionados aos indivíduos .

Por construtivismo, o sociólogo diz que existe de um lado uma gênese social dos esquemas de percepção, pensamento e ação que são constitutivos e forjam as estruturas objetivas e independentes referidas acima. Ele vai chamar esse ponto de habitus ${ }^{3}$. Destaca também que existe um outro lado, que são as estruturas sociais, chamados por ele de campo. Esses dois pontos, habitus e campo, são centrais na teoria bourdieusiana. São constituídos também por uma sólida relação de interdependência. O habitus é estruturado pelo campo, o campo é constituído pelo habitus. A estrutura social, internalizada e incorporada, forma o habitus, ao passo que o campo é habitus exteriorizado e objetivado (VANDENBERGHE, 1999, p. 49).

A concepção do autor é voltada a um olhar crítico e ao descortinar de uma articulação social, pois a partir de um construtivismo fenomenológico "busca na interação entre os agentes (indivíduos e grupos) e as instituições encontrar uma estrutura historicizada que se impõe sobre os pensamentos e ações" (THIRY-CHERQUES, 2006, p. 30). Tal entendimento está em consonância com a nossa proposta de estudo, ao considerar que o "estruturalismo construtivista" defende que as mais variadas ideias são tributárias à observância da condição de produção.

Destacamos que a aplicação empírica da teoria bourdieusiana mostra-se sistemática, tendo em vista que "a teoria científica apresenta-se como um programa de percepção e de acção só revelado no trabalho empírico em que se realiza" (BOURDIEU, 1998, p. 59). Sua proposta parte da ideia de que a dinâmica social acontece no interior de um campo em que os agentes e grupos possuem disposições específicas (habitus).

Juntas, a teoria dos campos e a teoria do habitus (com sua parafernália teórica: illusio, capital, etc.), que são internamente relacionados de tal maneira que uma parece ser ou um meio prático (modus operandi) ou uma

\footnotetext{
${ }^{3} \mathrm{O}$ conceito de habitus não nasce com Bourdieu e tem uma vasta história nas ciências humanas. Apesar disso, por não ser nosso objetivo de pesquisa, deixamos claro que só nos interessa nos alongar na explicação histórica.
} 
consequência (opus operatum) do outro, formam o "núcleo duro" do programa de pesquisa progressista de Bourdieu. (VANDENBERGHE, 1999, p. 61$)^{4}$

A maneira de perceber, julgar e valorizar o mundo constitui o habitus. É ele que aperfeiçoa a nossa forma de agir no dia a dia e que vai condicionar nosso princípio de ação, possibilitando ainda a observação das práticas classificáveis a partir de estruturas mentais. Trata-se de algo que se constrói e se modifica historicamente, e que, na essência, é um produto da interiorização das práticas sociais (BOURDIEU, 1998), vinculadas a um tempo e espaço social específico, possibilitando a incorporação dos atores sociais às regras do campo.

O habitus é ao mesmo tempo um sistema de esquemas de produção de práticas e um sistema de esquemas de percepção e apreciação de práticas. E, nos dois casos, suas operações exprimem a prática social em que foi construído. Em consequência, o habitus produz práticas e representações que estão disponíveis para classificação, que são objetivamente diferenciadas; mas elas só são imediatamente percebidas enquanto tal por agentes que possuem o código, os esquemas classificatórios necessários para compreender-lhes o sentido social (BOURDIEU, 1990, p. 158).

Por se tratar de algo adquirido ao longo do tempo, por meio das experiências vividas individualmente e de forma coletiva, o habitus é incorporado por aprendizagem explícita ou implícita. E por ser uma ideia em movimento, a interação entre essas duas experiências (individual e coletiva) também é mesclada e ressignificada continuamente. O conceito de habitus é um instrumento teórico que ajuda a refletir sobre a mediação entre a subjetividade dos indivíduos e os condicionamentos exteriores assimilados socialmente (SETTON, 2002). Com isso, podemos afirmar que o habitus é coletivo e individual, sendo o ponto unificador que vai gerar a coletividade, permitindo ainda a identificação de posições e estilo de vida unitário (THIRY-CHERQUES, 2006). Ao empregar a categoria habitus para refletir sobre a relação entre o indivíduo e a sociedade, supõe-se a existência de uma orquestração social simultânea das dimensões individual, pessoal e subjetiva, socialmente construídas. O habitus seria a socialização da subjetividade (SETTON, 2002).

O habitus deve ser pensado como um sistema flexível, em construção e constante mutação e não apenas como o resultado que se sedimenta pelo conjunto de experiências vivenciadas no âmbito de instituições sociais tradicionais. É, portanto, adaptável aos diferentes estímulos do mundo. O habitus é a trajetória que relaciona o passado e o presente; é

\footnotetext{
${ }^{4}$ Tradução livre para: "Together the theory of fields and the theory of the habitus (with their theoretical paraphernalia: illusio, capital, etc.), which are internally related in such a way that the one appears either as a practical medium (modus operandi) or as the consequence (opus operatum) of the other, form the "hard core" of Bourdieu's progressive research program."
} 
a história enquanto ela se faz; e é a expressão de uma "identidade social em construção" (SETTON, 2002, p. 67). Por não ser sinônimo da memória sedimentada e fixa, o habitus é um sistema de disposição aberto e em contínua construção, podendo ser alterado por novas experiências. É possível compreendê-lo como um repositório das disposições incorporadas, que são colocadas em prática pelos estímulos oferecidos pela conjuntura de um campo (SETTON, 2002).

Ao desenvolver o conceito, Bourdieu afasta a noção de habitus de certas alternativas da ciência social, como a da consciência ${ }^{5}$ e do inconsciente, a do finalismo e do mecanicismo, e ressalta a insuficiência da palavra hábito para expressar essa concepção. O conceito de habitus implica um rompimento com interpretações deterministas e unidimensionais das práticas sociais, buscando recuperar a noção dos indivíduos como agentes que são produto da história do seu campo social e de suas experiências acumuladas ao longo da experiência pessoal (SETTON, 2002). Por meio do termo habitus, o autor "desejava pôr em evidência as capacidades 'criadoras', activas, inventivas, do habitus e do agente (que a palavra hábito não diz), embora chamando a atenção para a ideia de que este poder gerador não o é o de um espírito universal, de uma natureza ou de uma razão humana" (BOURDIEU, 1998, p. 61). Na verdade, trata-se do poder de um agente em ação, podendo indicar "um conhecimento adquirido e também um haver, um capital (de um sujeito transcendental na tradição idealista)" (BOURDIEU, 1998, p. 61). O habitus não se trata, portanto, da expressão de uma ordem social baseada numa lógica puramente de reprodução e conservação; mas de uma ordem social constituída por estratégias e práticas por meio das quais os agentes atuam, adaptam-se e ajudam a produzir a história (SETTON, 2002).

O outro ponto central no estruturalismo construtivista de Bourdieu é o campo. Todas as ações que acontecem na vida social, nas sociedades modernas, reproduzem-se em campos que funcionam com relativa independência, constituindo-se em locais da prática social. Apesar dessa certa autonomia, os campos se relacionam entre si e atuam ao mesmo tempo combinados. A teoria nos mostra que a interação entre os campos provoca transformações e impacta o outro campo. É o caso do jornalismo, como se pode observar, por exemplo, com a mudança que o telégrafo provocou no modo de produção de notícias nos Estados Unidos, sendo uma das situações citadas por Marques (2005) de interferência de um campo no outro.

\footnotetext{
${ }^{5} \mathrm{O}$ autor destaca que sua intenção teórica, ao resgatar a palavra habitus residia em "sair da filosofia da consciência sem anular o agente na sua verdade de operador prático de construções de objecto" (BOURDIEU, 1998, p. 62).
} 
O campo social de Bourdieu, segundo relata Quiroga (2009), surge como uma terceira opção as duas grandes tradições teóricas da sociologia das ciências: a externalista ou externa e a internalista ou interna que se ligam, respectivamente, ao contexto e ao texto. A primeira delas, ao ressaltar os aspectos sociais e econômicos, "tem como pressuposto fundamental a ideia de que toda produção teórica é sempre o resultado de determinadas condições sociais" (QUIROGA, 2009, p. 59). Já a tradição internalista, baseada no fetichismo do texto automatizado, qualifica-se "pela crença no único e exclusivo contato com as obras, isto é, com as diferentes produções do espírito humano, como suficiente para se realizar determinado relato com pretensões científicas" (QUIROGA, 2009, p. 59-60).

Situando-se entre esses dois polos, surge a noção de campo que refuta a exclusividade da análise da obra (texto) ou mesmo do contexto, consistindo em "um universo intermediário, um espaço composto por agentes e instituições, entendido como campo, responsável, por exemplo, por 'produzir, reproduzir e difundir a arte, a literatura e a ciência'" (QUIROGA, 2009, p. 60). Quiroga (2009) ressalta que o conceito bourdieusiano de campo rechaça, portanto, de um lado, a noção de ciência pura - desvinculada do contexto social -, e a de uma suposta ciência vinculada a todo e qualquer aspecto político-econômico.

“A partir da lógica de cada campo é que sabemos quais as disposições importantes em cada um deles; há uma força arbitrária no princípio de todos os campos, com cada um possuindo sua lei fundamental" (GROHMANN, 2008, p. 2664). Eles "são microcosmos autônomos no interior do mundo social. Todo campo se caracteriza por agentes dotados de um mesmo habitus" (THIRY-CHERQUES, 2006), e sua estrutura decorre das relações objetivas entre as instituições e os agentes, de quem depende sua sobrevivência. Em cada um desses campos sociais, criados, encontram-se relações de poder, de lucros, monopólios, estratégias e interesses específicos (QUIROGA, 2009).

Todos os campos possuem propriedades universais, que são comuns a outros, e características próprias. Além do habitus próprio, fazem parte a estrutura dos campos, a doxa - a opinião consensual ou o senso comum - e as leis que o regem e que regulam a luta pela dominação do campo. Bourdieu utiliza, nesse contexto, o conceito de capital ${ }^{6}$, no sentido dos bens econômicos, culturais, sociais, simbólicos, entre outros. Dessa forma, entende o autor

\footnotetext{
${ }^{6}$ Bourdieu amplia a concepção marxista, compreendendo que não se trata somente o acúmulo de bens e riquezas econômicas, mas todo recurso ou poder que se manifesta em uma atividade social. "[...] Refere-se a um capital simbólico (aquilo que chamamos prestígio ou honra e que permite identificar os agentes no espaço social)”. Disponível em: http://revistacult.uol.com.br/home/2010/03/pequeno-glossario-da-teoria-debourdieu/
} 
que, assim como ocorre nos confrontos políticos ou econômicos, os agentes necessitam de um montante de capital para ingressarem no campo.

[...] a importância de cada agente (indivíduo ou instituição) na estrutura do campo é definida pela distribuição e posse do vulto de capital que cada um adquire ou conquista, em relação ao outro, em determinado momento. Estaria, então, precisamente na magnitude e no calibre desse capital adquirido e distribuído o elemento que introduz a diferença e os lugares ocupados entre agentes e instituições num determinado campo de forças (QUIROGA, 2009, p. 61).

Cabe frisar ainda que existem conflitos entre os agentes dentro de cada campo. De fato, há uma espécie de monopolização de capitais específicos pelos agentes que acumularam mais capital, possuindo maior poder pela via da violência simbólica (autoridade) contra os agentes com pretensão à dominação, os desfavorecidos. Não se trata de uma luta aberta, no modelo "classe dominante" contra a "classe dominada", mas de uma violência simbólica sutil, em que a dominação nem sempre é evidente ou explícita. A violência faz parte do sistema e é legitimada por cada campo, em que as práticas e instituições dotam os agentes dominantes com os ganhos advindos de todos os tipos de capital. A dominação é efeito de um conjunto de ações, complexamente engendrado, que escapa à consciência de cada um dos agentes e do comportamento das instituições dominantes sobre os demais. As classes sociais dominantes são aquelas capazes de transformar a modalidade de capital que detém como princípio hierarquizante do campo. Existe a tentativa de transformar as estruturas dos campos e subcampos, que se dá por meio da luta das classes sociais, no empreendimento de perverter o princípio econômico, cultural e simbólico que hierarquiza as posições internas do campo. $\mathrm{O}$ campo político é apenas uma das esferas em que esta batalha é travada, não a única, uma batalha constante pelo poder que é, no mais das vezes, inconsciente aos seus agentes (THIRYCHERQUES, 2006).

Conforme explica Bourdieu (1997), o campo jornalístico, assim como o literário ou artístico, possui uma lógica própria, cultural, que se incute aos profissionais da área por meio de restrições e controles cruzados. Estes controles, os jornalistas os impõem uns aos outros, interpretados nesse caso como princípios deontológicos, inclusive como princípio basilar da reputação de honorabilidade profissional. Ao mesmo tempo que é um "campo de forças", uma estrutura que impõe restrições a seus agentes, o campo é também um "campo de lutas", em que os agentes atuam segundo suas posições relativas, mantendo ou modificando a estrutura deste campo (THIRY-CHERQUES, 2006). 
Além do capital econômico, os capitais específicos podem ser interpretados como capital cultural, capital social e capital simbólico. O primeiro deles refere-se às habilidades, ao conhecimento e às informações, sendo classificado como o conjunto de qualificações intelectuais produzidas e transmitidas pela família, e pelas instituições escolares (THIRYCHERQUES, 2006). O capital cultural é considerado por alguns autores como composto por dois aspectos distintos, mas conectados. Existe um aspecto "incorporado", das capacidades culturais que são específicas e transmitidas pela socialização primária de uma geração a outra e há também o "institucionalizado" das credenciais conferidas institucionalmente como títulos e diplomas (SILVA, 1995).

O capital cultural não é somente uma subcultura de cada classe e de cada um dos setores que a compõem, mas serve para caracterizar estas subculturas. Por sua dimensão utilitária e pelo poder que ele é capaz de conferir, dá-se o nome de capital cultural a determinados conhecimentos, preferências e atividades desempenhadas culturalmente. Ele é um recurso de poder alternativo, sobretudo aos recursos econômicos, sendo capaz de também fornecer distinção e relevância especiais àqueles que o detém (SILVA, 1995). Há um sentido estratégico na concepção do capital cultural, conforme concebido por Bourdieu, funcionando ainda como um mecanismo que atua na manutenção e reprodução das condições sociais que o produziram, reiterando e reforçando suas conexões com as outras modalidades assumidas pelo capital, o simbólico, o social e o econômico. Entretanto, Bourdieu oferece vislumbres de que a cultura pode sim ser um veículo de transformação e trânsito social num campo em que cada grupo ou agente parece adotar uma estratégia baseada nas suas capacidades próprias de manejar e administrar os diferentes capitais disponíveis (SILVA, 1995, p. 27-28).

O conceito bourdieusiano de capital cultural ou capital informacional apresenta múltiplas dimensões e áreas de atuação, que o dotam de complexidade e abrangência e podem torná-lo de difícil manejo tanto teórico quanto empírico. Entretanto, são essas mesmas complexidade e abrangência que permitem compreender e destacar as formas como os elementos culturais vêm a constituir uma fonte de poder (SILVA, 1995). Já o capital social está imbricado com os relacionamentos e com a rede de contatos. Há um reforço mútuo que opera entre o capital cultural e o capital social, pois a delimitação dos contatos sociais do agente permite a exclusividade de uma cultura, e esta base cultural, por sua vez, possibilita justamente que os contatos sociais se formem e perdurem no tempo (SILVA, 1995).

Por fim, o capital simbólico correspondente ao conjunto de rituais de reconhecimento social, que compreende o prestígio, a honra, etc, e se constitui como uma síntese dos demais (cultural, econômico e social). Todos eles são reversíveis uns nos outros, podendo 
transformar-se nos diferentes tipos de capital que compõem um campo. Em cada campo existe um conflito permanente, pois os capitais não se distribuem igualmente entre os agentes. Aqueles indivíduos e grupos dominantes no campo procuram preservar seus privilégios, em oposição aos demais grupos e indivíduos, que buscarão a redistribuição dos capitais (THIRYCHERQUES, 2006).

As lutas perpetradas por novos grupos ou grupos em declínio, bem como os esforços individuais daqueles que buscam se prevenir contra o ocaso da classe a que pertencem fazem parte daquilo que Bourdieu chama de "trajetória social de grupos" e "trajetórias indivíduais". As estratégias empregadas individualmente podem resultar na mobilidade de agentes no espaço social, permitindo um deslocamento social. Bourdieu trata, portanto, de "deslocamentos verticais" como, por exemplo, as mudanças que ocorrem a um indivíduo ao longo de sua trajetória profissional de ascensão numa carreira (de professor primário a docente universitário) e "deslocamentos transversais", as mudanças na atuação profisssional do indivíduo que produzam ganho social (de professor primário a industrial). Conforme cada indivíduo os possua, os diferentes tipos de capital são solicitados e reconvertidos nestas estratégias, sobretudo o capital cultural (SILVA, 1995).

Uma pesquisa que considere os critérios da teoria estabelecida por Bourdieu tem por objetivo identificar as estruturas, tanto as que regem as relações de um determinado segmento social (estruturantes do campo) quanto as que são estabelecidas por estas relações sociais (estruturadas, portanto). Para tanto, aplica-se uma metodologia que consiste no emprego dos conceitos pré-formatados que jogarão luz sobre o conjunto das relações internas que explicam a lógica de um campo - os objetos sociais (THIRY-CHERQUES, 2006). Na perspectiva deste trabalho, pretendemos analisar as mudanças ocorridas na pauta jornalística relacionada à produção de conteúdo para tablets no âmbito da convergência.

É preciso proceder a determinados enfrentamentos quando se deseja tratar da Teoria do Jornalismo, para dar sentido ao investimento neste trabalho epistêmico, que é tanto conceitual quanto metodológico e teórico. O primeiro desafio é o rompimento com certo espontaneísmo, atrelado a uma visão restrita à expressão material deste objeto de estudo, que é a prática jornalística. É preciso transpor esse obstáculo epistemológico para alcançar o afastamento desejável para a contemplação do campo jornalístico como objeto de estudo. Uma mirada restrita à prática afasta-se da possibilidade de crítica ao fenômeno, realizando apenas a descrição das rotinas produtivas e seus produtos ou a análise histórica das instituições do campo: "associações, revistas científicas, programas de pós-graduação, linhas de pesquisa, produção em congressos" (SILVA, 2009). Há um risco ao se fundamentar as 
pesquisas sobre o Jornalismo em suas práticas: por um lado, um enfoque sobre as transformações nas tecnologias empregadas pode subverter os estudos do campo, como se o objeto de estudo se resumisse às mutações tecnológicas; por outro, debruçar-se sobre a tradição histórica resulta em estudos normativos, do Jornalismo como dever ser, reproduzindo um conjunto de normas textuais, de gêneros, procedimentos éticos (como verdade e imparcialidade) e princípios de conduta (como objetividade e atualidade). Nos estudos conduzidos sobre o campo jornalístico, o enfoque dado à prática profissional oculta a dimensão simbólica do fenômeno, dificultando uma efetiva episteme do Jornalismo (SILVA, 2009).

O próximo capítulo tem como objetivo apresentar o desenvolvimento da profissão jornalística, criando assim o campo e o habitus da profissão. Para isso, selecionamos os séculos XIX e XX e apresentamos alguns pontos importantes no processo de construção das empresas e práticas jornalísticas. Nosso intuito não é esgotar a temática, mas pontuar alguns aspectos importantes para a consolidação das rotinas produtivas. Feito isso, apresentamos a evolução das pesquisas sobre Gatekeeper até chegar ao Newsmaking. São mais dois pontos fundamentais que dão sustentação ao nosso olhar para o desenvolvimento e a execução da pauta. 


\section{CAPÍTULO II}

\section{A FORMAÇÃO DO CAMPO JORNALÍSTICO: DO GATEKEEPER AO NEWSMAKING}

\subsection{A EXPANSÃO DA IMPRENSA E A CONSOLIDAÇÃO DAS ROTINAS JORNALÍSTICAS}

É importante destacar, antes de apresentarmos mais elementos para o desenvolvimento e a profissionalização do jornalismo, que, geralmente, a abordagem desse tema é feita a partir de um comparativo entre os modelos anglo-americano e francês. Como o Brasil adotou o modelo americano, enfatizando a produção de um jornalismo informativo, em detrimento do modelo interpretativo francês, privilegiamos o primeiro deles na construção deste tópico. Não pretendemos com isso fazer uma cronologia linear e sim destacar pontos importantes no processo de desenvolvimento da indústria jornalísticas. Também gostaríamos de deixar claro que não buscamos apresentar os modos como o jornalismo era produzido no passado (características, tensões, valores, princípios normativos, formas de produção, entre outros). Como esse percurso histórico está fora dos objetivos desta tese, cabe frisar que nos debruçaremos apenas sobre alguns desses elementos.

Ainda, apenas para delimitar os conceitos operacionais deste trabalho, quando utilizamos o termo 'jornalismo', estamos nos referindo ao conjunto ou à globalidade de um fenômeno, que vai abarcar o jornalismo como instituição e como atividade prática. "Estas duas dimensões são manifestações interligadas do mesmo fenômeno" (FRANCISCATO, 2003, p. 22). “A ‘instituição jornalística' está relacionada ao aspecto coletivo e organizacional do jornalismo, [...], que aglutina, organiza e dá unidade a normas de ação e valores culturais institucionalizados". Esse processo transformou o individualismo em uma atividade realizada em coletivo e organizacional. “A instituição jornalística é, ao mesmo tempo, um 'corpo', uma forma social e uma estrutura operacional de produção". Estamos falando, nesse caso, do jornalismo como campo que possui o seu habitus.

A atividade jornalística está relacionada ao conjunto das práticas, normas, valores e conhecimentos que assentem, orientam e direcionam os jornalistas. Apesar de integrarem o corpo coletivo, são os jornalistas que possibilitam que a atividade seja um conjunto dinâmico 
de conhecimentos. Essas práticas são recriadas diuturnamente em seu exercício (FRANCISCATO, 2003). Essa atuação consistiria no habitus que os agentes desenvolvem, no sentido dado por Bourdieu (1998), ao fazerem parte de um campo, tema sobre o qual nos debruçamos no primeiro capítulo desta tese.

Os séculos XIX e XX são considerados por muitos autores (ROSHCO, 1975; GENRO FILHO, 1987; CHALABY, 1996; TRAQUINA, 2002; SCHUDSON, 2010) como períodos que provocaram transformações profundas e marcaram o jornalismo moderno. São marcos de criação e aperfeiçoamento da profíssão, momento que passa a ganhar reconhecimento social. As etapas anteriores fazem parte da "pré-história" do jornalismo informativo (GENRO FILHO, 1987) ou período pré-jornalístico (SOUZA, 2008).

As mudanças no jornalismo aconteceram, principalmente, nos Estados Unidos e, em menor grau, na Inglaterra (CHALABY, 1996, p. 304) e são marcadas por "interferências" econômicas, sociais e tecnológicas da época. É relevante destacar que o desenvolvimento da economia de mercado, aliada à revolução industrial, construiu um terreno propício ao surgimento das empresas de comunicação nos moldes que conhecemos na contemporaneidade (OLIVEIRA, 2005). "O crescimento do aspecto industrial e comercial do jornalismo, aliandose às inovações tecnológicas, afetou os modos iniciais como o jornalismo era produzido durante a maior parte do século XIX" (FRANCISCATO, 2002, p. 25).

Schudson (2010) debate essas mudanças a partir de alguns de seus aspectos desencadeadores. Ele propõe que o jornalismo e a imprensa passaram por inovações e três elementos dão sustentação aos seus argumentos: o tecnológico, o da alfabetização e o da história natural. O primeiro, o tecnológico, aponta para os avanços de impressão, locomoção e comunicação. A impressora a vapor, as ferrovias, os canais de navegação e o telégrafo são alguns dos exemplos citados pelo pesquisador como impulsionadores desse progresso. A tecnologia disponível e a estrutura social vigente (ROSHCO, 1975) influenciaram o modo de produção da imprensa, constituindo os dois fatores que vão garantir também a atualidade e a visibilidade das notícias produzidas na época. Outro ponto que teria desencadeado essas mudanças é a alfabetização da população (TRAQUINA, 2002). Entretanto, Schudson (2010) questiona, apesar de muitos (CHALABY, 1996; FRANCISCATO, 2002; SOUZA, 2008) afirmarem ser esse um dos pontos alavancadores do desenvolvimento do jornalismo, qual foi esse tipo de alfabetização que cresceu no século XIX, tendo em vista que a instrução recebida na sociedade da época era mais direcionada ao comércio. Por conta disso, afirma que era pouco provável que esses indivíduos alfabetizados se tornassem um grande público leitor. Em relação ao terceiro elemento, a história natural, compara-se a história da população com a do 
jornal. As mudanças da vida moderna são vistas por Schudson (2010) como condutoras da modernização dos impressos, demonstrando caminhos iguais também na ligação entre o aumento do público leitor e o aumento da população.

Esses três pontos estão entrelaçados à dinâmica social da época. De fato, o “desenvolvimento [do jornalismo] está diretamente relacionado a certos fenômenos observados nesse estágio das sociedades industriais capitalistas, como o crescimento da população urbana" (OLIVEIRA, 2005, p. 2). Os jornais tornam-se importantes produtos de consumo nas cidades urbanizadas (GENRO FILHO, 1987) e é a partir dessa necessidade e do avanço tecnológico que os periódicos passam a ter maiores tiragens.

Outro ponto explicativo está inserido no campo político. A ampliação de governos democráticos e a conquista pela sociedade de direitos fundamentais, como a liberdade de expressão, instigaram a população a ter mais participação e interesse por assuntos políticos e factuais e lançaram as bases para o delineamento do papel do jornalismo na sociedade (TRAQUINA, 2002; OLIVEIRA, 2005). É nessa nuance, com inspiração nos ideais iluministas, que surgem os debates sobre jornalismo e quarto poder.

Há quem acredite que "[...] na sua origem há um esforço intelectual artesanal que resulta de avaliação pessoal, de técnica e de organização" (BAHIA, 1990, p. 10). Por isso, o autor afirma que o desenvolvimento do jornalismo não se dá por uma base econômica, mas sim social. Bahia ignora, todavia, o desenvolvimento das empresas como um fator impulsionador do jornalismo. Florescem, nesse cenário, dois tipos de atuação no jornalismo: um mais engajado, inspirado nos ideais democráticos iluministas, que lida com a produção da notícia a partir de um ideal de serviço público, e outro comercial, que busca no sensacionalismo uma alternativa para aumentar as vendas das edições, ou seja, o jornalismo visto como negócio. Traquina (2005a) chama o primeiro deles de polo ideológico e o outro de polo econômico.

Apesar de parecem pontos opostos, eles possuem elementos em comum. Neveu (2006) elenca cinco aspectos que caracterizam o jornalismo anglo-americano e que estão presentes nos dois modelos de jornalismo citados acima.

O primeiro ponto é a coleta de informação (news-gathering). "O jornalista americano se definiu antes de qualquer coisa como um profissional da busca por notícia". Durante a Guerra da Secessão, são utilizadas, pela primeira vez, as técnicas da reportagem e da entrevista. (TRAQUINA, 2002). Surge então a figura do repórter, que enviava relatos do conflito. "Em meados do século XIX, já podemos falar em meios de comunicação de massas", diz Alsina (2009, p. 123). O autor explica que os cidadãos passam a utilizar a 
imprensa como a principal fonte de transmissão de acontecimentos. A postura da imprensa torna-se mais ativa: "agora não se trata de receber a informação e comentá-la, mas de descobrir o acontecimento." A fórmula dos jornais estava baseada em dois princípios: baixo preço dos periódicos e a divulgação de histórias que despertariam o interesse humano (ROSHCO, 1975). Esse movimento ficaria conhecido como penny press (TRAQUINA, 2002).

O segundo aspecto citado por Neveu é a predominância do discurso da objetividade. Essa defesa floresce principalmente da necessidade de separar a informação do comentário. Uma das estratégias dos jornais e dos jornalistas para conseguir isso foi a adoção da pirâmide invertida, ou técnica do $\operatorname{lide}^{7}$. O terceiro aspecto seria o atendimento às necessidades práticas e cotidianas como um traço da imprensa anglo-americana: "a busca por leitores se traduz também na multiplicação das editorias de serviço, que vão de receitas de cozinha às crônicas religiosas", comenta Neveu (2006, p. 24). Um quarto aspecto é o status da imprensa como atividade empresarial. Os proprietários dos meios de comunicação passam a ser conhecidos como mercadores de notícias ou barões da imprensa. Foi o desenvolvimento da publicidade e o aumento das vendas dos periódicos que possibilitaram o descolamento da dependência econômica dos políticos dos governos déspotas (TRAQUINA, 2002) para a transformação em negócio. "A lógica empresarial contribui assim para uma profissionalização forçada" (NEVEU, 2006, p. 25).

A última característica do jornalismo anglo-americano é a formação de um grupo profissional assalariado, que busca sua remuneração a partir da originalidade de suas informações. "Essa racionalização reforça uma habilidade profissional à base de técnicas, de capacidade de investigação, de uma escrita normatizada, que demanda no fim do século passado, cursos de jornalismo nas universidades" (NEVEU, 2006, p. 26).

Além do florescimento das escolas de jornalismo, o processo de consolidação do jornalismo provocou também algum desenvolvimento dos estudos voltados ao jornalismo. Inicialmente, apesar de ter sido colocado em segundo plano, principalmente "[...] por influência da guerra fria e do crescente interesse por outras práticas midiáticas [...]” (MEDITSCH, SHWAAB, 2014), o papel do jornalismo na democracia motivou debates filosóficos sobre a imprensa.

\footnotetext{
${ }^{7}$ Não existe consenso sobre o surgimento da técnica. Alguns autores (TRAQUINA, 2002; NEVEU, 2006) defendem que ela aparece inicialmente no século XIX, outros (SOUSA, 2008; JORGE, 2003) mostram que, desde a antiguidade, a pirâmide invertida já era usada como estrutura da narração. O lide, primeiro parágrafo do texto, busca responder a seis perguntas básicas: o que, quem, quando, por que, como e onde.
} 


\subsection{DO GATEKEEPING AO NEWSMAKING: DESENVOLVIMENTO DAS TEORIAS}

No campo das pesquisas de comunicação de massa (Mass Communicatin Research) a teoria do gatekeeping é frequentemente mencionada (MCQUAIL, WINDAHL, 1993) como uma das mais antigas a ter como objeto de pesquisa o jornalismo (ALSINA, 2009). “Gatekeeping é o processo de seleção e transformação de vários pequenos pedaços de informação na quantidade limitada de mensagens que chegam às pessoas diariamente [...]" (SHOEMAKER, VOS, 2011, p. 11). Destacamos que o processo determina não somente qual informação será escolhida, mas também qual será o conteúdo (fontes, angulação e hierarquização) e a natureza (gênero e formato) das mensagens.

[...] A entrada nos canais de notícias é controlada pelos gatekeepers, que determinam quais eventos têm acesso e passam por muitos gates pelo caminho. As forças na frente e por trás dos gates constrangem ou facilitam o movimento das informações sobre um evento por diversas seções nos canais. Há muitas forças que influenciam nas notícias, como foi mostrado no modelo hierárquico desenvolvido por Shoemaker e Reese (1996). (SHOEMAKER et al, 2010, p. 60)

As investigações sobre os processos de seleção das informações que circulariam na imprensa possuíam um determinado enfoque teórico até Kurt Lewin (1947) fornecer aos estudos da comunicação a metáfora do gatekeeper no manuscrito Frontiers in group dynamics II. Channels of group life; social planning and action reseach. Embora sua pesquisa não tenha sido originalmente aplicada ao estudo da comunicação, Lewin mostra como "itens" são selecionados ou rejeitados através de "canais" e afirma que essa fórmula poderia ser aplicada ao fluxo de notícias (SHOEMAKER et al, 2001).

David Manning White (1950) foi um investigador pioneiro a aplicar a ideia de Kurt na comunicação. "A metáfora do gatekeeper ofereceu aos primeiros pesquisadores de comunicação um modelo para avaliar a maneira como ocorre a seleção e a razão pela qual alguns itens são escolhidos e outros são rejeitados" (SHOEMAKER, VOS, 2011, p. 23). A teoria também forneceu possibilidade de investigações sobre a forma como o conteúdo é modelado, estruturado, posicionado e cronometrado. White (1950) fez seu estudo num jornal de uma pequena cidade (non-metropolitan). Ele convenceu um editor, a quem chamou de $\mathrm{Mr}$. Gates, a armazenar todos os textos que recebia das agências Associated Press, United Press e International News Service durante uma semana, em fevereiro de 1949. Em sequência, Mr. 
Gates também forneceu suas razões para escolher ou rejeitar cada um dos itens das agências. Esses motivos complementaram a análise do pesquisador, que pôde verificar o material utilizado e rejeitado.

É apenas quando estudamos as razões dadas por Mr. Gates para ter rejeitado quase $90 \%$ da conteúdo recebido (em sua busca pelos $10 \%$ para os quais ele tinha espaço) que começamos a entender o quanto as atitudes e a comunicação das notícias são subjetivas e dependentes dos julgamentos de valor baseados no próprio conjunto de experiências do gatekeeper [...] (WHITE, 1950, p. 386, tradução nossa) ${ }^{8}$.

A figura 1 abaixo é uma proposta de visualização (MCQUAIL, WINDAHL, 1993, p. 166) da teoria do gatekeeper. No modelo conceitual de White, as fontes de notícias (N) enviam itens noticiáveis para os gatekeepers, os quais podem rejeitar algumas informações N1 e N4 são exemplos de rejeição - e outras são transformados em notícias a serem enviadas ao público (M). Vemos nesse caso que as diversas fontes, como ministérios, universidades, autarquias e empresas privadas, por exemplo, mandam informações para os jornalistas, que podem aceitar ou não publicar. As que passam no processo de seleção recebem tratamento jornalístico e são enviadas aos receptores.

Conceptual Model

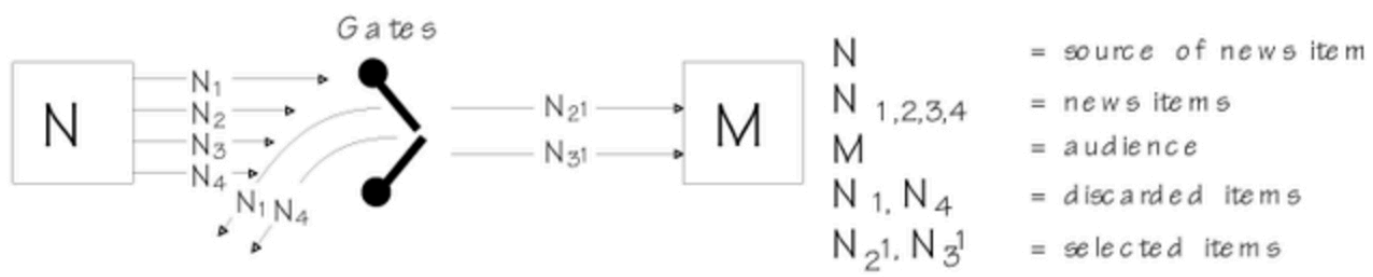

GRÁFICO 1: Modelo de White sobre gatekeeper (MCQUAIL, WINDAHL, 1993, p. 166)

O modelo de White foi ampliado e criticado em trabalhos posteriores (MCQUAIL, WINDAHL, 2011). Ele serviu de base para diversas pesquisas futuras (GIBER, 1956; WESTLEY, MACLEAN, 1957; MCNELLY, 1959; BASS, 1969; SHOEMAKER, 1991) que indicaram novos caminhos e descobertas sobre por que determinados acontecimentos viram notícia e outros são ignorados. Mostraram também que a escolha tem sido apenas uma parte do processo de gatekeeping.

Giber (1956) foi um dos primeiros pesquisadores que apresentaram conclusões antagônicas às de White. O estudioso pesquisou como era feita a seleção de notícias de

\footnotetext{
${ }^{8}$ It is only when we study reasons given Mr. Gates for rejecting almost nine-tenths of the wire copy (in his search for the one-tenth for which he has space) that we begin to understand how highly subjective how reliant upon value-judgments based on the "gate keeper's" own set of experiences, attitudes and the communication of "news" really is $[\ldots]$
} 
agências por 16 editores de jornais impressos. Diferentemente de White (1950), que identificou que os valores pessoais de Mr. Gates influenciavam nas escolhas, Giber (1956, p. 432 , tradução nossa $)^{9}$ diz que “o editor do periódico descrito nesse estudo está preso em uma camisa de força de detalhes mecânicos". O pesquisador destaca ainda que "seus valores de notícia são elementares e amplamente estruturados". Entre as característas das escolhas relatada no artigo, a mais citada foi a proximidade com a comunidade. Contudo, outros elementos se mostraram fundamentais: disponibilidade de verba, número de informações disponíveis, pressão do tempo e adequabilidade do conteúdo à política editorial da empresa também influenciaram na hora da escolha da informação. Giber (1956) afirma que o processo de seleção é mecânico e que os editores são passivos. Ele conclui que a organização e suas rotinas são mais importantes que as características individuais do selecionador. Nesse modelo, o que importam são as restrições impostas pela indústria ao gatekeeper.

O modelo de Westley e Maclean (1957), bem como o de Giber (1956), compreendem a organização midiática como algo homogêneo, com regras rígidas. Nesses estudos, os trabalhadores da mídia atuam como gatekeepers de forma idêntica. Diferentemente do primeiro estudo de White (1950), que estava direcionado a decisões de uma pessoa e suas escolhas pessoais, aqui as organizações e suas regras possuem um peso grande nas seleção dos trabalhadores midiáticos.

Ao combinar a ideia de gatekeeper como uma atividade organizacional com o modelo psicológico de comunicação interpessoal de Newcomb (1953), Westley e Maclean (1957) inovam. Trata-se do padrão mais popular de comunicação de massa (SHOEMAKER, VOS, 2011, p. 30), que, no seu modelo mais simples, “[...] envolve a pessoa A que envia a informação sobre um objeto X para uma pessoa B”. Os autores perceberam que o modelo $\mathrm{ABX}$ poderia ser modificado para estudar a comunicação de massa e incluiram um $\mathrm{C}$ e um $\mathrm{F}$. Com isso, propuseram que a mensagem $\mathrm{X}$ pode sair de emissores $\mathrm{A}$ ou $\mathrm{B}$, passando ou não pelo canal de mídia $(C)^{10}$. O retorno (f) pode ser enviado da audiência para os emissores, assim como da mídia para os emissores. O modelo aponta também que algumas mensagens podem ser rejeitas ou simplesmente modificadas pelos meios de comunicação.

"Claramente, em uma situação de comunicação de massa, um grande número de Cs recebe de um grande número de As e transmite para um número bem maior de Bs, que

\footnotetext{
9 "the telegraph editor described in this study is caught in a strait jacket of mechanical details". [...] "his news values are elementary and broadly structured".

${ }^{10}$ Nesse caso a organização é o gatekeerper.
} 
simultaneamente recebe de outros Cs" (WESTLEY, MACLEAN, 1957, p. 35, tradução nossa $)^{11}$.

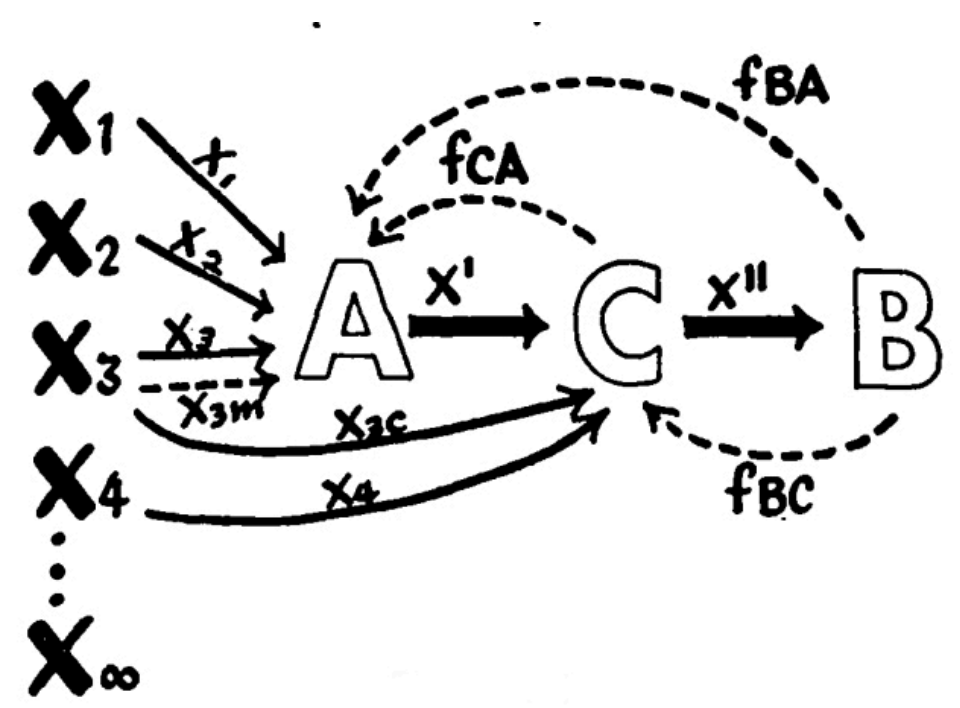

GRÁFICO 2: Modelo organizacional proposto por Westley e Maclean para a comunicação de massa (1957, p. 35).

A pesquisa de McNelly (1959), em seguida, voltou a aproveitar a ideia de indivíduos atuando como gatekeepers. O pesquisador estava preocupado com o fluxo de produção de notícias internacionais e acabou desenvolvendo uma representação esquemática (FIGURA 3) que mostra o passo-a-passo do fluxo no qual as informações passam por uma série de porteiros, comunicadores e intermediários.

Um evento $(E)$ chama a atenção de um correspondente estrangeiro $\left(C_{1}\right)$, que escreve uma história sobre ele (S). Ele envia a história a uma agência regional, na qual um editor ou um repórter do escritório (rewriteman) $\left(\mathrm{C}_{2}\right)$ pode editar a história $\left(\mathrm{S}^{\prime}\right)$ para enviá-la ao escritório central da agência de notícias. Lá um editor de texto (deskman) $\left(\mathrm{C}_{3}\right)$ pode combinála com uma história relacionada $\left(\mathrm{S}_{\mathrm{II}}\right)$ de outro país. A história resultante ( $\mathrm{S}$ ') vai para um escritório estadual ou nacional onde outro deskman $\left(\mathrm{C}_{4}\right)$ pode alterar a versão ( $\mathrm{S}$ ',') e transmiti-la para o editor de um jornal ou para um editor de notícias de rádio ou televisão $\left(\mathrm{C}_{5}\right)$, que também podem alterar o conteúdo $\left(\mathrm{S}_{\mathrm{III}}\right)$ e passá-lo para o leitor ou ouvinte $(\mathrm{R})$.

\footnotetext{
11 "Clearly, in the mass communication situation, a large number of Cs receive from a very large number of As
} and transmit to a vastly larger number of Bs, who simultaneously receive from other Cs" 


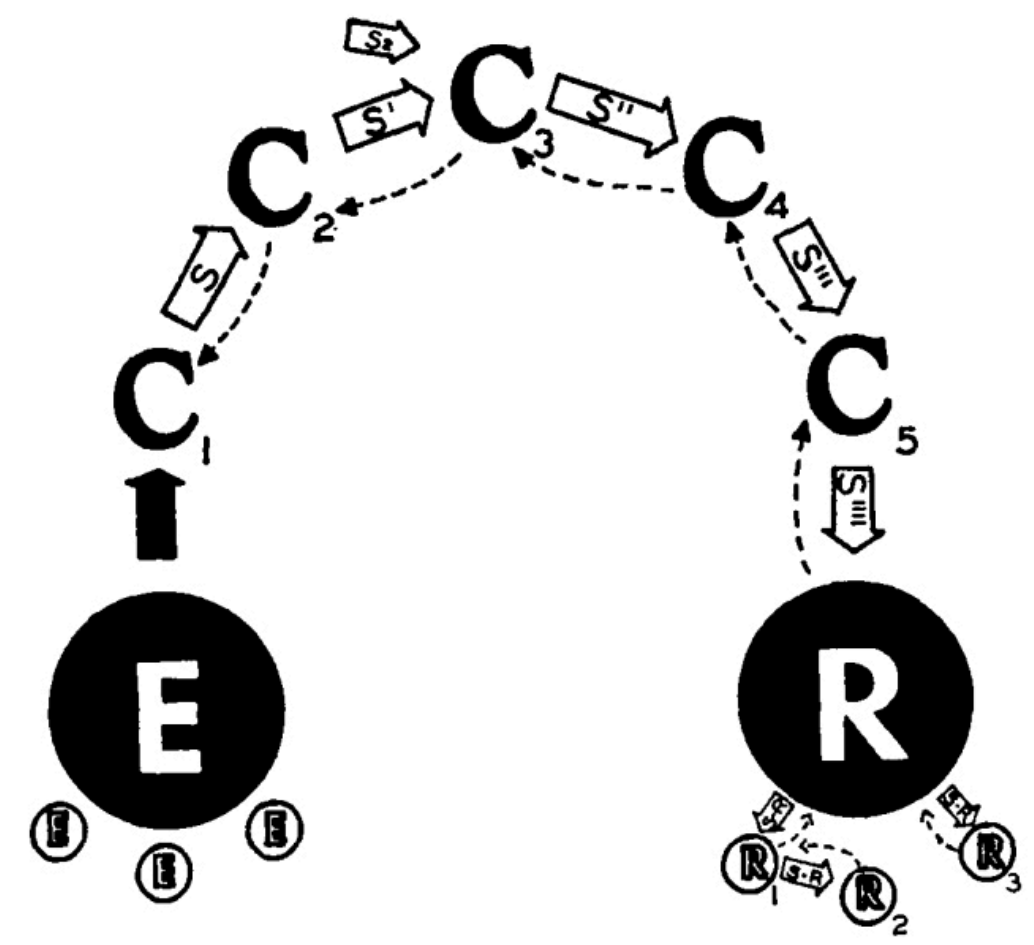

GRÁFICO 3: O modelo de fluxo de informações internacionais indica que a informação deve passar por múltiplos gatekeerps (MCNELLY, 1959, p. 25).

Explicando a figura acima, Shoemaker e Vos (2014, p. 32) relatam que se trata de "uma história $(\mathrm{H})$ [que] é escrita sobre um evento (E). A história passa de um gatekeeper (C) para outro, cada um dos quais pode cortar, reorganizar ou fundir a história com uma outra antes que ela chegue ao receptor (R) final'. Por fim, no modelo proposto, as setas representam o retorno (feedback), que pode chegar em diferentes gatekeepers.

Vale notar que, nesse estudo, há diversos selecionadores, como correspondentes, editores de agências de notícias e dos meios de comunicação e revisores. Eles são peças centrais no processo de seleção e construção das versões noticiosas que chegarão ao público. A análise de McNelly (1959) já apresentava a complexidade e o caráter circular na produção noticiosa. Pela primeira vez um estudo vai detalhar com mais clareza o percurso que uma informação percorre para que seja publicada no jornal, passando da fonte de notícias até chegar à audiência. A novidade na proposta está justamente em mostrar os múltiplos portões que a informação cruza para alcançar o p, não focando apenas no editor, como Giber (1956) fez. Mcnelly (1959) deixa claro também que, apesar do peso do editor no processo de seleção, outros profissionais também são responsáveis pelo procedimento de triagem e pelo formato em que os conteúdos chegarão ao consumidor final. 
Seguindo a evolução dos estudos sobre gatekeeper, interessa-nos também o trabalho proposto por Bass (1969), que observou os indivíduos dentro da organização midiática. Para o autor, "o processo de fluxo de notícias deve ser dividido por suas funções em segmentos de coleta e processamento de notícias. A atenção das pesquisas deve cair sobre o coletor de notícias, pois é ele que toma as decisões importantes. " (BASS, 1969, p. 62, tradução nossa) ${ }^{12}$.

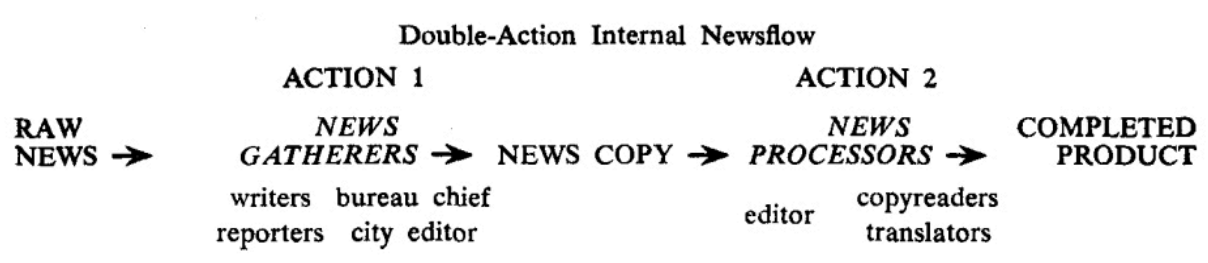

GRÁFICO 4: Coletores e processadores de noíticias são os dois indivíduos mais importantes no processo de gatekeeping (BASS, 1969, p. 62).

O modelo de Bass (1969) apresenta o fluxo de notícias de dupla ação em o que interessa é o indivíduo inserido no contexto da organização. As informações chegam cruas (raw news) por vários canais aos coletores de notícias (News Gatherers) que as transformam em notícias (news copy). Como exemplo de coletores, o autor cita redatores, repórteres, chefe de redação e editor de cidade. Este seria o primeiro tipo de gatekeeper. O segundo tipo de gatekeeper (processadores de notícias - news processors) modifica e prepara o material para ser distribuído ao público. São citados como exemplos editores, tradutores e revisores. Essa segunda espécie é quem dá a palavra final no processo de produção. Bass (1969) aplica o olhar de McNelly (1959) no seu estudo, ampliando a noção de White (1950), ou seja, buscou compreender o papel dos selecionadores individuais, chegando até a ideia dos múltiplos selecionadores. O que diferencia as duas visões é a classificação de Bass, que propõe os dois tipos distintos de selecionadores.

A partir desses trabalhos, outros pesquisadores (CHIBNALL, 1977; GANDY, 1982) progrediram e acrescentaram alguns elementos à teoria. Contudo, interessa-nos o trabalho ampliado por Pamela Shoemaker (1991) e Shoemaker e Reese (1996), que propõem uma visão abrangente do gatekeeping, mostrando que, por trás do processo, existe também um sistema social, um controle ideológico e cultural, o que nos aproxima mais do debate teóricometodológico proposto no primeiro capítulo de Bourdieu.

Dentro dessa perspectiva, Mcquail e Windahl (1993, p. 126) explicam que:

\footnotetext{
12 "the news flow process should be divided by functions into news gathering and news processing segments.
} Research attention should be focused on the news gatherer, for it is he who makes the significant decisions" 
Ela chama atenção para os fatores sociais e institucionais no ofício (incluindo fontes, mercados anunciantes, grupos de interesse e governo). Para ela, gatekeeping frequentemente envolve mais de uma organização comunicacional [...] e múltiplos atos de gatekeeping que acontecem em uma organização de mídia. (MCQUAIL, WINDAHL, 1993, p. 126, tradução nossa $)^{13}$.

Segundo Shoemaker (1991), o fenômeno de seleção das informações pode ser verificado em outros níveis que vão além do individual, como, por exemplo, nas rotinas organizacionais. A pesquisadora diz que se um evento requer muita despesa e/ou tecnologia para produzir a história, isso pode surtir um efeito contrário na escolha da notícia. Se o acontecimento vira notícia, depende da intensidade relativa destas duas forças, juntamente com outras forças que ainda serão identificadas. (SHOEMAKER, 2001, p.234, tradução nossa)

Tais forças vão influenciar a escolha das notícias. Aquela autora, em parceria com Voz (2011), propõe cinco níveis para o estudo do gatekeeping em contextos contemporâneos, a saber: 1) o dos profissionais da comunicação individuais (suas atitudes políticas, por exemplo); 2) o das rotinas ou práticas do trabalho em comunicação (a pirâmide invertida, por exemplo); 3) o nível organizacional (a análise de variáveis como parâmetros de participação de propriedade na mídia, por exemplo); 4) o nível de análise sócio-institucional, incluindo as influências do governo e grupos de interesse; e, 5) o nível do sistema social, com a análise de variáveis (ideologia e cultura, por exemplo) (SHOEMAKER; REESE, 1996).

\subsubsection{Nível de análise individual}

O primeiro envolve o background, bem como os antecedentes pessoais, do profissional. Trata-se do nível individual. A individualidade do agente, que trabalha com a racionalidade no campo jornalístico, é apresentada como algo importante na sua atuação. Antes do lado profissional, os processos comportamentais do indivíduo são observados. As questões pessoais também são fundamentais na escolha.

\footnotetext{
${ }^{13}$ She also draws attention to the social and institutional factors at work (including sources, advertisers' markets, interest groups and government). In her account, gatekeeping often involves more than one communication organization [...] and multiple acts of gatekeeping take place within a media organization.
} 
Para explicar o processo de tomada de decisões, têm-se teorias da Psicologia utilizadas por Shoemaker e Vos (2011), quais sejam: 1) Associacionismo; 2) Gestaltismo; e, 3) Processo de informação. Os pesquisadores procuram elementos que expliquem os modos de raciocínio de um gatekeeper.

A teoria do Associacionismo aponta que é através das relações lineares e diretas que o indivíduo faz racionalmente suas escolhas. As ideias evocam outras ideias ou se conectam a diferentes imagens, concebidas ou lembradas. Esta encontra-se associada essencialmente à Psicologia Behaviorista, que defende o estímulo-resposta. A partir daí, é possível inferir que a memória, a atualização e a capacidade de correlacionar fatos são aspectos fundamentais no processo de atuação.

É possível afirmar que quando existe uma reforço em uma associação positiva, com base nas relações estímulo-resposta, ela ganha mais força. Efeito igual acontecerá aos negativos; ou seja, quanto maior são as associações de eventos pretéritos, mais força terá e é provável tal informação se torne notícia; cruze o portão. Os gatekeepers têm a disposição de categorizar os acontecimentos e, quando da existência de muitos eventos, eles tendem a fazer uso do processo em questão para a execução de seu trabalho. Neste sentido, tem-se como ponto fraco da teoria em questão - um tanto mecânica (SHOEMAKER; VOS, 2011).

O Gestaltismo é a segunda teoria. Ela trata do método de raciocínio de modo holístico, uma vez que defende que os pensamentos não são somente a soma de juízos individuais. Aqui, os artifícios psicológicos podem ser mais bem compreendidos quando analisados como diversos, elaborados e estruturados. Logo, o raciocínio é visto de modo amplo. Tem-se a identificação de dois tipos de estruturas, a saber: 1) o raciocínio produtivo - que explora as informações antigas, aplicando-as; e, 2) o raciocínio produtivo - que insere a imaginação e o uso de novas informações, configurando-se em algo contínuo, não focado em cadeias e associações de ideias.

A terceira teoria - o processo de informação - gesta a resolução de dificuldades a partir de uma cadeia de caminhos lógicos, com rasgos lineares do Associacionismo, mas sem a suposição de que as associações ou as relações entre os estímulos reforçadas de modo positivo ou negativo. Tal processamento de informação, sem dúvida, reduzirá as tarefas do juízo.

\subsubsection{Nível de análise das rotinas}


O nível das práticas padronizadas e das rotinas de produção está acima do nível pessoal do jornalista. Neste sentido, Shoemaker e Vos (2011) observam que a informação que passa pelo gatekeeper é transformada em diferentes pontos no processo de produção.

Nas redações, Ericson, Baranek e Chan (1987, p. 125) ${ }^{14}$ observaram que o repórter deve aprender a se organizar de tal modo que suas atividades se tornem hábitos, ou seja, o habitus de Bourdieu (1998): "A habitualização diminui as escolhas e torna a ação rotineira possível. A própria instituição jornalística, evidentemente, é estruturada para produzir habitualização, canalizando a curiosidade do repórter para as trilhas da ocupação." Roshco (1975, p. 105), por sua vez, apontou que o consenso no processo de seleção de notícias (news judgement) minimiza a necessidade de discussão e acelera o papel-desempenho rotineiro: “As rotinas diárias, pressionadas pelo tempo, de coleta e produção de notícias podem ser conduzidas somente porque a maioria dos julgamentos de notícias, se revisados, seria concordado por pares e superiores" $" 15$.

Nos estudos de Shoemaker e Vos (2011), dentro da construção analítica dos modelos de rotina, considera-se, primeiramente, o campo da audiência e sua influência, pois, embora se tenha apenas uma ideia abstrata da mídia sobre o que o público aprecia ou despreza, os receptores possuem seu papel no processo de seleção de notícias. Na contemporaneidade, com a internet e as métricas de acesso, tal cenário começa a se ampliar. Considerar o público como uma grande massa foi se tornando retrógrado na medida em que evoluíram os meios. Assim, o surgimento de estudos que procuraram dividir a audiência em contextos e grupos específicos contribuiu significativamente para o avanço das ideias de seleção. "A era organizacional demandou dois princípios: primeiro, que a principal preocupação de uma organização era a sua sobrevivência; e segundo, que as organizações existem para agradar seus constituintes" (ALLEN, 2005, p. 379). ${ }^{16}$

Com as novas especificidades, o selecionador das informações tem como aliado, junto aos seus métodos, as reflexões acerca dos desejos do público, que sabia, depois de pesquisas de mercado, por exemplo, alguns dos assuntos mais aptos a passarem pelo portão, conforme os interesses midiáticos de atração de receptores.

\footnotetext{
14 "Habitualization narrows choices and makes routine action possible. Of course the news organization itself is structured to produce habitualization, canalizing the reporter's curiosity into the grooves of the occupation".

15 "The essence of news judgement is that it is consensual. Consensus minimizes the need for discussion and speeds routine role-performance. The daily, time-pressured routines of news-gathering and production can be conducted only because most news judgements, if reviewed, would be concurred in by peers and superiors".

16 "The organizational era had commanded two principles: first, that an organization's first concern is survival; and second, that organizations exist at the pleasure of their constituents."
} 
O uso das fontes jornalísticas também constitui grande parte do conteúdo que passa pelos portões - o que serviu para a descoberta da intensidade de aparições de fontes oficiais, moldando os pensamentos de modo contundente.

\begin{abstract}
A dependência rotineira de fontes oficiais por parte da mídia pode modelar o noticiário de diversas formas - ela privilegia aqueles que estão no poder (Bennett, 1996), reduz a diversidade de pontos de vista (Hallin, 1989; Liebler, 1993; Schiffer, 2006) e reforça estereótipos de gênero (Armstrong e Nelson, 2005). Por exemplo, Zoch e Turk (1998) mostraram que as fontes de notícias ainda são predominantemente masculinas, construindo, assim, um mundo no qual os homens têm mais autoridade do que as mulheres. Dito de um modo simples, o conteúdo é desenvolvido de maneira previsível porque os gatekeepers compartilham rotinas de coleta e processamento de informações. (SHOEMAKER e VOS, 2011, p. 82).
\end{abstract}

Outras técnicas estão atreladas ao uso de fontes/personagens, como, por exemplo, a construção e angulação das temáticas na notícia e ao formato e linguagem noticiosas em termos de precisão e factualidade. Historicamente, as noções de objetividade, equilíbrio e equidade incorporam a suposição de que os jornalistas são agentes neutros e imparciais, onde suas decisões se dão de modo técnico e uniforme. Tuchman (1972) denomina tal ação de ritual estratégico, que inclui a negativa da influência do viés pessoal, separando o fato da opinião, bem como a inserção de diferentes visões.

“As fontes são pessoas, são grupos, são instituições sociais ou são vestígios - falas, documentos, dados - por aqueles preparados, construídos, deixados" (PINTO, 2000, p. 278). Pinto (2000) observa que as fontes direcionam suas falas para posições e relações sociais, para interesses e pontos de vista, para quadros espaço-temporalmente situados. As fontes utilizadas pelos jornalistas, espontâneas ou não, estarão sempre interessadas, desenvolvendo sua atividade a partir de estratégias e com tácticas bem delimitadas.

As noções supramencionadas são construídas com o intuito de melhorar a qualidade dos processos das organizações. As rotinas estratégicas visam proteger os jornalistas de acusações e buscam cumprir os papéis esperados pelos comunicadores. Sobre a questão, Tuchman (1972) quantificou quatro estratégias, a saber: 1) oferecer ao público dois lados dos eventos de opiniões conflitantes; 2) inserir fatos tidos como verdadeiros por todos; 3) usar aspas de um entrevistado para dar uma posição do jornalista, sem assumir a responsabilidade pela citação; e, 4) organizar hierarquicamente as informações mais importantes do texto, no formato da pirâmide invertida.

Ainda foi possível encontrar e destacar os estudos de nível rotineiro que “especificam nove características de um evento de notícias que determinam as chances deste 
atravessar vários portões midiáticos" (SHOEMAKER; VOS, 2011, p. 85). Galtung e Ruge (1965), ao debater o gatekeeping, apontam que vários valores-notícia se sobrepõem à individualidade dos jornalistas no processo de seleção de informações que cruzarão o portão. Tal análise pressupõe que o evento deve dialogar com o cronograma do veículo, possuir grande magnitude ou intensidade, contar com clareza, relevância cultural, ser consoante com as expectativas ou inesperados, ter continuidade com eventos passados, além de encaixar-se na composição do dia a dia do veículo, observando o fato de que "os valores do gatekeeper e de sua sociedade influenciam a seleção, muito mais do que os outros oito fatores" (SHOEMAKER; VOS, 2011, p. 85). Os encaminhamentos transmitidos dos jornalistas mais experientes para os mais novos, bem como os manuais de estilo, deixam o processo de escolha mais padronizado e tradicional.

Em geral, os jornalistas zombavam da impraticabilidade dos manuais referentes à coleta de informações ou ao estilo no qual elas devem ser apresentadas. $\mathrm{O}$ aprendizado do ofício não envolve a consulta de tais textos de autoridade. Ele vem da consulta de notícias, do escrutínio dos editores, conversas com colegas mais experientes, e de fazer o trabalho (ERICSON; BARANEK; CHAN, 1987, p. 132). ${ }^{17}$

A exploração das rotinas, de modo comercial, evidencia a relevância desse nível para melhorias em diversos setores dos veículos, barateando alguns custos e diminuindo erros. Mas, ainda existem forças atuando no processo de gatekeeping, que deixam o sistema mais complexo, forçando o portão, de forma positiva e negativa.

\subsubsection{Nível de análise organizacional}

O nível de análise organizacional explora o sistema social delimitado dos locais que servem como objeto do presente estudo. Cada um desses locais, em suas rotinas, possuem características próprias (ADGHIRNI, 2012). Existem nesses espaços códigos de escolha e pré-seleção. Há nesses espaços um tipo de orientação coletiva, de grupo.

\footnotetext{
17 "In general, journalists scoffed at the impracticality of rule books pertaining to the search for information or the style in which it is presented. Learning the craft does not involve consultation of such authoritative texts. It comes from consulting news texts, being scrutinized by editors, talking to more experienced colleagues, and doing the work".
} 
Essas orientações são decisivas quando se observa o que aquele meio busca lograr. Aquelas que visam o lucro apontaram a existência de uma redução de itens sobre questões públicas e governamentais, e um aumento de itens sobre as questões concernentes à vida privada, à autoajuda, aos esportes e ao entretenimento.

Esse processos pode não ser identificados em pesquisas, alerta Shoemaker e Vos (2011). Principalmente por não estarem documentados. Os autores alertam que eles são de relevância fundamental para o compreensão dos níveis de análises.

\subsubsection{Nível de análise das instituições sociais}

Para identificar as influencias que gatekeepers recebem não basta uma completa análise dos indivíduos e de suas organizações. Assim, é preciso observar a questão de modo institucional, que é orientada via mercado, governo, audiência e outros aspectos.

A capacidade da audiência de alterar as decisões do gatekeeping possui influências contestadas e diversificadas. Na contemporaneidade, com as métricas oferecidas pelos acessos via web, há uma maior influencia da audiência.

É preciso destacar os efeitos gerados pelos anunciantes é citado por Shoemaker e Vos (2011) como determinantes no ritmo que a imprensa estabelece no processo de publicação de conteúdos. Demissão de profissionais e retiradas de conteúdos são citados como possíveis ações deflagradas pelos anunciantes quando seus interesses não são seguidos.

Dessa forma, a ideia de público acaba misturando-se com os interesses dos anunciantes. Isso pode confundir alguns gatekeepers, que podem ignorar as aspirações da audiência em detrimento do interesse dos anunciantes.

Em geral, a visão transmitida pelos jornalistas não vem de suas próprias experiências, já que as versões são extraídas das fontes. Um outro grupo que tende a influenciar o processo de escolha são os relações públicas. Esses profissionais defende os interesses dos seus assessorados. Sobre os tipos de fonte, que envolvem os diversos pontos elencados nesse tópico, Sigal (1973) assim classifica tais canais de informação: 1) canais de rotina; 2) canais informais; e, 3) canais empreendedores.

O eventos que não são espontâneos geralmente são produzidos pelos canais de rotina. São ocorrências criadas para chamar atenção midiática. Setores específicos para tratar 
com a impressa em empresas públicas ou privadas são criadas. Geralmente esse tipo de serviço, ou setor, são criados ou contratados por pessoas físicas e públicas.

É comum assessores de comunicação, políticos e pessoas que acupam espaços de poder, manter relações com jornalistas e acabam por abastecê-los de dados de bastidor. São a partir dessas relações que informações de bastidores são circuladas de forma extraoficial e, em geral, atende ao interesse de quem a repassa.

Tal postura da fonte é denominada por Molotch e Lester (1974) de promotores de notícias (news promoters) - classificação que visa demonstrar a intencionalidade de transformar fatos em notícias, fazendo uso de processos jornalísticos, a fim de facilitar que os acontecimentos atravessem os portões midiáticos. Os canais empreendedores se referem a eventos espontâneos e estão relacionados àquilo que nasce da conversa do jornalista com outrem. Um elemento destacado por aqueles autores é a reflexão neste processo. Aqui, a atitude deixa de ser da fonte e parte do profissional da informação. O jornalista necessita se portar criticamente perante a sua fonte, a fim de alcançar a informação, extraindo-a a partir do diálogo estabelecido.

\subsubsection{Nível de análise do sistema social}

Este ponto vai defender que é impossível compreender a publicação de conteúdos da mídia sem antes compreender diversos elementos da estrutura social que ela está inserida. São exemplos disso o sistema politico partidário e as características do Estado, o jogo de relações entre a sociedade civil e os interesses políticos e econômicos dominantes, entre outros.

O gatekeepers agem, segundo este ponto, de acordo com os seus ambientes culturais, ofertando uma ampla perspectiva dentro de tal abordagem, mas restringindo o conhecimento de fora dos ambientes parecidos. Assim, são perceptíveis as alterações contextuais na passagem pelo portão, como preconizam Shoemaker e Vos (2011), quando colocam que as mudanças podem alterar variados setores produtivos das organizações.

\subsection{A SOCIOLOGIA DE NOTÍCIAS E O NEWSMAKING}


Os estudos predominantes no início das pesquisas da Mass Communication Research abordavam o chamado selecionador (gatekeeper $^{18}$ ) (ALSINA, 2009) e foram praticamente os primeiros trabalhos de newsmaking (ZELIZER, 2004). É justamente por isso que a década de 50 é considera o marco inicial dos estudos sociológicos sobre o jornalismo nos Estados Unidos e na Inglaterra. Essas pesquisas buscavam detalhar o processo de produção da notícia, especificamente sobre as rotinas do trabalho dos jornalistas (FRANCISCATO, 2003; ZELIZER, 2004).

Apesar de Franciscato (2003) demarcar a década de 50 como o marco inicial das pesquisas dessas corrente nos Estados Unidos, a consolidação dos estudos está amplamente relacionada à concepção e delineamento social e industrial do jornalismo dentro do que seria o processo de produção da notícia. Grandi (1985) qualifica esse momento como "metáfora industrial, pois "estaríamos então diante do que vem sendo conhecido como a produção da notícia (news making)" (ALSINA, 2009, p. 213).

É importante enfatizar que os estudos do gatekeeper, em nossa compreensão, são percursores da consolidação de uma corrente mais ampla de pesquisa: o newsmaking. É possível propor e olhar para o newsmaking como uma teoria que abrigaria as investigações realizadas com auxílio do gatekeeping. Ambas estariam inclusas na corrente teórica chamada de sociologia dos emissores ou sociologia da produção de notícias (ROSCHO, 1975; VASQUÉS, 2003). Os exames desta perspectiva buscam identificar processos e práticas sociais relacionados à produção das mensagens informativas feitas pelos jornalistas no contexto dos meios noticiosos. O sociólogo de notícias tem a preocupação com a gênese da notícia e não com suas consequências. O resultado disso, segundo o pesquisador, é que surgiram críticas mal direcionadas em fazer essa distinção. "Ao chamar atenção para eles, se estabelece uma fundação para a moldura conceitual com a qual o conteúdo de notícias pela imprensa diária pode ser estudado como um fenômeno social” (ROSCHO, 1975, p. 6, tradução nossa) ${ }^{19}$.

Roshco (1975, p. 18, tradução nossa) ${ }^{20}$ diz que "uma preocupação fundamental da sociologia de notícias é por que determinados indivíduos, instituições e eventos - e não outros - são rotineiramente observados pela imprensa enquanto o resto é normalmente

\footnotetext{
${ }^{18}$ É preciso deixar claro também que nem todos os estudos sobre gatekeeper têm o jornalismo como objeto. Alguns estudos (CANTOR, 1980; HIRCH, 1977) utilizam a metáfora do gatekeeper para investigar a seleção de conteúdos para entretenimento, por exemplo.

${ }^{19}$ Misdirected criticisms of the press have resulted from a failure to make these distinctions. Drawing attention to them lays a foundation for the conceptual framework within which the news content of the daily press can be studied as a social phenomenon

${ }^{20}$ a fundamental concern of the sociology of news is why particular individuals, institutions, and events - rather than others - are routinely observed by the press while the rest are usually overlooked.
} 
desconsiderado." Essas investigações buscam detalhar o processo de produção da notícia, especificamente sobre as rotinas do trabalho dos jornalistas. Os constrangimentos e as condicionantes da estrutura organizacional das empresas também são examinados (FRANCISCATO, 2003).

$\mathrm{O}$ início das pesquisas nessa área é marcado pelo legado funcionalista ${ }^{21}$. O abandono, ou enfraquecimento, dessa tradição acontece entre o final dos anos 1960 e durante a década de 1970. As posições alternativas a essa visão estão justamente na ênfase na noção de "produção" - a notícia é feita, não encontrada. Condizente ao pensamento de Shoemaker e Vos (2011), Tuchman (2002, p. 80 e 81) afirma que não é a atitude ou "preconceito" dos jornalistas individuais, mas seu contexto social e organizacional que determina principalmente como as notícias são feitas. Este denominador comum foi apontado nos títulos de toda uma lista de estudos influentes sobre o fazimento (making), criação (creating), manufatura (manufacturing) e decisão (deciding) do que é notícia. ${ }^{22}$

$\mathrm{Na}$ contemporaneidade, essas pesquisas sobre produção de notícias podem ser interpretadas também como uma reação aos modelos funcionalistas dos meios de comunicação de massa, que foram dominantes em meados do século XX, particularmente nos EUA, como também em outros países, como o Brasil, que adotaram a cultura dominante americana.

Como em grande parte das ciências sociais, a pesquisa inicial sobre as notícias foi, frequentemente, qualitativa, explorando o lugar deste gênero estratégico na vida política e social. Max Weber (1958a [1918]) concluíra que a imprensa era um conjunto de organizações políticas e não retransmissores neutros de informação ou escândalo, e que jornalistas eram 'políticos profissionais'. Robert E. Park (1922) examinou o papel dos jornais na construção da coesão social na heterogênea nação Americana. Por volta dos anos 1950, entretanto, novos estudos se juntaram à emergente ortodoxia científico-social com metodologias quantitativas associadas a terias funcionalistas. (TUCHMAN, 2002, p. 79) ${ }^{23}$

O newsmaking seguiria três vertentes: a cultura profissional dos jornalistas; a organização do trabalho; a organização dos processos produtivos. A socióloga defende que cada notícia tem uma realidade interna e, portanto, o jornalista encarregado de transformar a

\footnotetext{
${ }^{21}$ Nesta correte de pesquisa observa-se o objeto de estudo perguntando-se sobre suas funções.

${ }^{22}$ This common denominator was signaled in the titles of a whole list of influential studies on 'making,' 'creating,' 'manufacturing,' and 'deciding' what is news."

${ }^{23}$ Like much social science, early research on news had often been qualitative, exploring the place of this strategic genre in political and other social life. Max Weber (1958a [1918]) had found that the press was a set of political organizations rather than being neutral relayers of information or scandal, and that journalists were 'professional politicians.' Robert E. Park (1922) had examined the role of newspapers in building social cohesion in the heterogeneous American nation. By the 1950s, however, news studies were joining the emerging social-scientific orthodoxy of quantitative methodologies coupled with functionalist theories.
} 
informação em notícia, deve prezar pela realidade e evitar a submissão às rotinas produtivas e aos critérios de noticiabilidade e aquilo que transforma um fato corriqueiro em notícia, os valores-notícia.

Alsina (2009) vai defender que nessa corrente de pesquisa, existem duas vertentes de estudo: de um lado, as organizações formais e a estrutura administrativa dos meios jornalísticos, principalmente no que tange à introdução de aparatos tecnológicos no processo produtivo da notícia; e, por outro, o jornalista como arquiteto da notícia inserido no contexto de construção da realidade social. A evolução da pesquisa, com o consequente descolamento das pesquisas funcionalistas, abre caminhos de pesquisa para compreensão da macro (macrossociológica) e micro (microssociologia) das rotinas de produção dos jornalistas (TUCHMAN, 2002). Na perspectiva macrossociológica, a informação jornalística é o resultado de uma extensa cadeia operacional no interior da qual os jornalistas promovem negociações entre si para manufaturar um produto final a ser disponibilizado para o públicoconsumidor. 
The news-production process

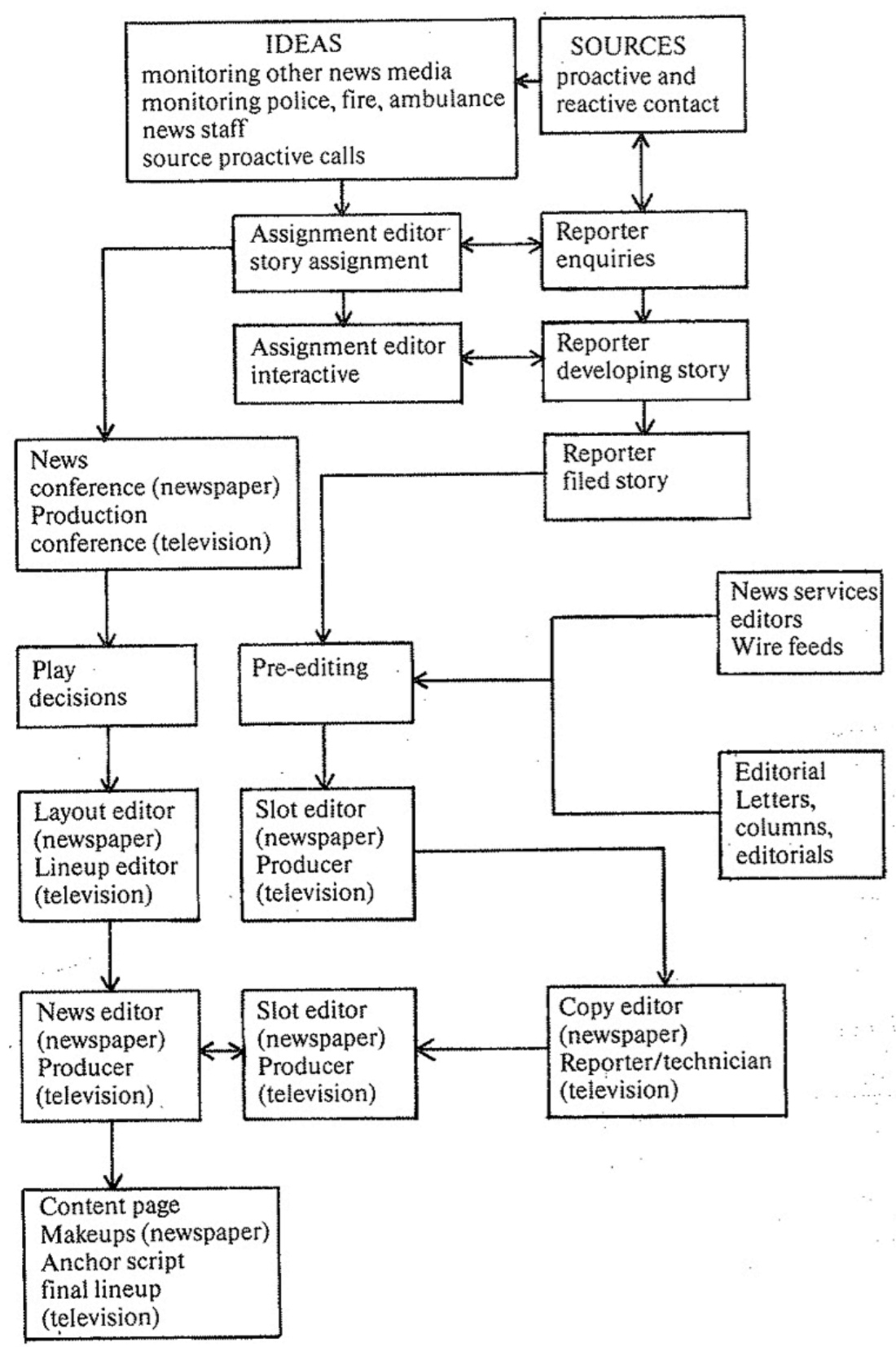

GRÁFICO 5 - O processo interno ou a descrição da microssocilogia do newsmaking (ERICSON, BARANEK E CHAN 1987, p. 98).

Nesta perceptiva macrossociológica, Gans (1979) vai mostrar que existem linhas de montagem nas organizações noticiosas. Para que o produto final chegue a ser concretizado, os agentes que trabalham nessas instituições precisam atuar em unicidade para manufaturar um produto contra um deadline. E é neste ponto que a formação do habitus garante o funcionamento de lógica fabril e uma certa estabilidade na produção. 


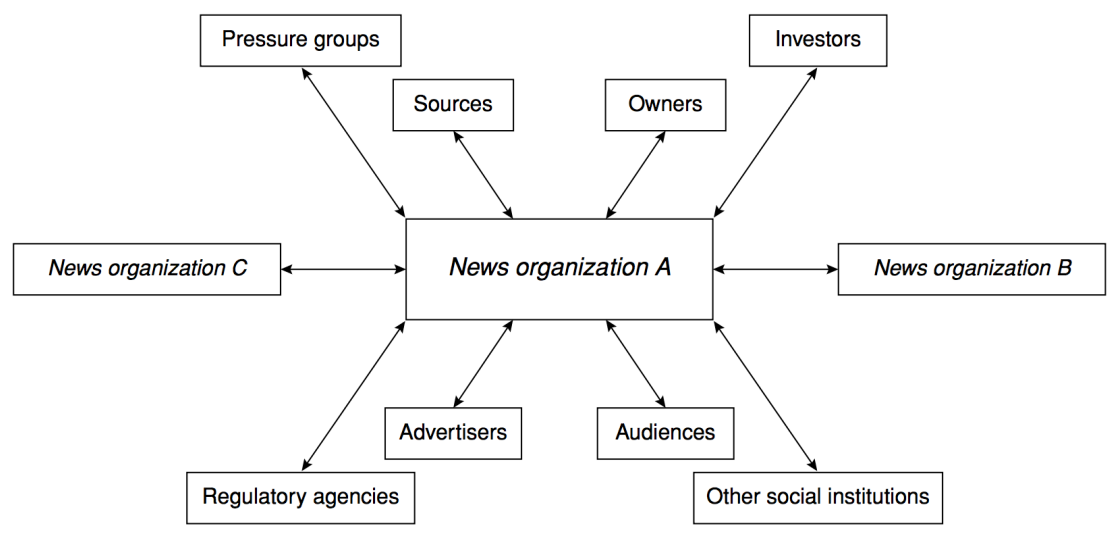

GRÁFICO 6 - Modelo Macrossociológico (TUCHMAN, 2002, p. 80).

Já a macrossociológica, afirma Stunf (2006), apresenta a informação jornalística como o produto resultante de um embate de forças sociais externas, sejam elas institucionais ou não, frequentemente conflitantes e entre determinadas organizações jornalísticas. Essas forças compreendem pelo menos quatro tipos: agentes econômicos, políticos, de origem e de audiência.

Os agentes econômicos, que são os proprietários e investidores, terão como objetivo políticas e procedimentos direcionadas ao produto jornalístico que garantam um lucro, no curto ou longo prazo. "Ao fazê-lo, eles respondem aos interesses do público e do anunciante. Ao mesmo tempo, cada organização de notícias deve se voltar para seus concorrentes, que operam no mesmo ou em um campo de força relacionado" (TUCHMAN, 2002, p. 80, tradução nossa $\left.{ }^{24}\right)$.

Os agentes políticos, que são entidades legais e outras entidades reguladoras, estabelecem o quadro geral em que operam as organizações de notícias. Historicamente, tanto no Brasil como em outros países, o financiamento público das empresas de comunicação representa uma alternativa ou um complemento substancial à publicidade.

Haveria também os agentes de origem, as fontes, que "representam linhas de informação necessárias alimentando notícias e, portanto, são cultivadas para assegurar cobertura contínua de setores sociais chave.” E são também, "tanto as fontes políticas oficiais

\footnotetext{
${ }^{24}$ In doing so, they respond to both audience and advertiser interests. At the same time, each news organization must orient itself toward its competitors, which operate in the same or a related force field.
} 
como as organizações de interesse $a d$ hoc constituem grupos de pressão que buscam uma voz nas notícias" (TUCHMAN, 2002, p. 80, tradução nossa ${ }^{25}$ ).

Por último, ficam os agentes de audiência. Os meios de comunicação estão sempre atentos ao mercado consumidor, tentando entender, em um sentido mais amplo, os "públicos" de uma organização de notícias, compreendido também como um conjunto heterogêneo de instituições, como outros meios de comunicação jornalístico.

Ao apreender e buscar equalizar essas forças externas, uma organização de notícias concebe internamente práticas e procedimentos para realizar seu trabalho diário de notícias. Todas essas forças exercem impacto nas notícias em diferentes momentos (TUCHMAN, 2002). Os dois âmbitos mantêm em comum as premissas conceituais de que as notícias são entendidas como reconstruções simbólicas da realidade e elaboradas a partir de processos sociais complexos; a ideia dos meios noticiosos como organização burocrática, derivada da sociologia das profissões e das organizações; e a convicção de que a empresa jornalística é, antes de qualquer coisa, uma empresa (VASQUÉS, 2003).

A construção da notícia aparece então como um processo de três fases: produção, circulação e consumo (ALSINA, 2009). Wolf (2003) também defende três etapas: coleta, seleção e edição/apresentação no jornalismo. Apesar de terem nomes diferentes usados pelos autores, entendemos que as etapas são as mesmas e que são aplicáveis ao nosso trabalho. Apesar de aqui defendermos que essas rotinas são divididas em três fases, deixamos claro que o processo informativo se compõe de etapas que variam segundo a organização do trabalho de cada redação e de cada meio de comunicação (ADGHIRNI, 2012).

As rotinas são importantes porque "diante da variedade e imprevisibilidade dos acontecimentos, as empresas jornalísticas precisaram se organizar no tempo e espaço, unificando as práticas e estabelecendo rotinas para a produção da notícia" (AGNEZ, 2011, p. 65). São práticas organizativas e estruturantes da profissão. Sousa (2002) entende os processos e rotinas como técnicas convencionais e de certa forma mecanicistas de produção de alguma coisa que pareça obedecer essencialmente a fatores sócio-organizacionais. Isso sem excluir o fato de que determinadas pessoas têm rotinas próprias ou de que a cultura e o meio social afetam essa produção.

Defendemos que a execução da pauta perpassa essas três etapas de produção jornalística. Como são momentos circulares não-lineares, entendemos que a pauta é

\footnotetext{
25 "represent necessary lines of information feeding into news, and hence are cultivated to ensure continuous coverage of key social sectors. [...] both official political sources and ad hoc interest organizations amount to pressure groups seeking a voice in the news".
} 
consolidada na circulação ou no consumo do produto jornalístico, que é a/na instância de recepção. Apesar de poder soar estranho afirmar que a pauta perpassa a instância de recepção, acreditamos que as expectativas do receptor também são levados em conta no momento em que o conteúdo é proposto. Na edição, os conteúdos também são alterados e podem ganhar novas nuances, levando em consideração todos os aspectos elencados por Shoemaker e Vos (2014). Com isso, entendemos que a pauta é central na rotina produtiva (explicamos melhor no capítulo IV).

No próximo capítulo apresentamos uma nova etapa de desenvolvimento da profissão: o jornalismo pós-industrial. Para isso, delineamos um cenário e a partir de uma perspectiva da inovação no jornalismo, discutimos uma quinta geração do jornalismo digital, o Continuum Multimídia (BARBOSA, 2009a). Esses conceitos nos darão subsídios para apresentar e debater o jornalismo praticado para tablets, suas características e rotinas de produção. 


\section{Capítulo III}

\section{CONVERGÊNCIA JORNALÍSTICA E AS TRANSFORMAÇÕES DE PRÁTICAS}

A monenclatura jornalismo digital é empregada de forma variada por diversos autores, contudo, há um certo consenso de que é o termo mais amplo (PRIMO, 2010). Como mencionamos anteriormente, essa terminologia tem uma influência forte dos norteamericanos e, de início, estava muito atrelada ao jornalismo feito para a web. Contudo, para este trabalho, o termo jornalismo digital abarca as múltiplas formas de produção e disseminação de conteúdo, abrangendo as plataformas móveis e todas os outros meios de comunicação convencionais.

A tecnologia digital, nesse tipo de prática, é utilizada para todo e qualquer procedimento que implica no tratamento de dados em forma de bits. Na contemporaneidade, praticamente todo jornalismo é digital. Com isso, estamos afirmando que esse tipo de jornalismo "privilegia os meios tecnológicos, através dos quais as informações são trabalhadas, como fator determinante para elaborar a denominação do tipo de prática jornalística, seja na instância da produção ou na da disseminação de informações jornalísticas” (MIELNICZUK, 2003, p. 24).

\subsection{CONVERGÊNCIA JORNALÍSTICA}

Uma das características marcantes do jornalismo digital é o fenômeno de convergência jornalística, que se traduz na integração de mídias, meios e redações e na criação de novos formatos de narrativa. É importante deixar claro que, embora existam diversos estudos sobre convergência, percebe-se que não há consenso sobre o termo (SALAVERRÍA; GARCIA AVILÉS; MASIP, 2007; BARBOSA, 2009b; CANAVILHAS, 2012). Em diversos âmbitos da comunicação, desde a década de 1970, o fenômeno da convergência vem sendo debatido sob diferentes angulações (cultural, tecnológica, empresarial, legal/regulatória, produtiva, da narrativa e/ou dos conteúdos, dos usuários) (BARBOSA, 2009a).

Um dos autores a captar com mais precisão as transformações em curso no seio da sociedade e do mercado comunicacional na contemporaneidade foi Henry Jenkins (2009). Ao 
falar da cultura da convergência, o pesquisador descreve a cooperação entre múltiplos mercados midiáticos e o comportamento nômade dos públicos dos meios de comunicação. A convergência altera as relações entre os mercados, indústrias, gêneros midiáticos, audiências e o consumo dos meios de comunicação. $\mathrm{O}$ olhar do pesquisador não tem um viés somente tecnológico, ele busca compreender o fenômeno cultural (no próximo tópico explanaremos melhor a convergência, mais detidamente a convergência jornalística).

Apesar de não fazer uma relação direta com o jornalismo pós-industrial, o entendimento de Barbosa (2009) tem proximidade com o novo momento por que passa o jornalismo. "É na década de 2000 que ela [a convergência] desponta como força e vai originar variados estudos acadêmicos que têm sistematizado uma teoria da convergência jornalística". Nessa época, eclodem também estudos mais comerciais, ligados a consultorias que buscavam "atender à demanda das empresas informativas na implementação da integração de redações, dos novos fluxos de produção e de rotinas de trabalho convergentes" (BARBOSA, 2013, p. $35)$.

Como conceito operacional, a convergência jornalística é entendida neste trabalho como:

[...] um processo multidimensional que, facilitado pela implantação generalizada das tecnologias digitais de telecomunicação, afeta o âmbito tecnológico, empresarial, profissional e editorial dos meios de comunicação, propiciando uma integração de ferramentas, espaços, métodos de trabalho e linguagens anteriormente separadas, permitindo que os jornalistas elaborem conteúdos para serem distribuídos através de múltiplas plataformas, mediante as linguagens próprias de cada uma. (SALAVERRÍA, GARCÍA AVILÉS, MASIP, 2010, p. 59, tradução nossa ${ }^{26}$ )

Com isso, estamos dizendo que a convergência é entendida como um processo e junção das redações, que afeta as esferas Tecnológica, Profissional, Empresarial e Editorial/Conteúdo dos meios de comunicação, levando-as a passar por profundas transformações, e desencadeia a junção de ferramentas, espaços, rotinas de trabalho e linguagens. Há, neste contexto, uma produção de conteúdos para que sejam distribuídos mediante múltiplas plataformas, por meio das linguagens próprias a cada uma delas. (DOMINGO et al, 2007; SALAVERRÍA, GARCÍA AVILÉS et al, 2007 GARCÍA AVILÉS, MASIP, 2008, 2010; SALAVERRÍA, NEGREDO, 2008).

\footnotetext{
${ }^{26}[\ldots]$ “.un proceso multidimensional que, facilitado por la implantación generalizada de las tecnologías digitales de telecomunicación, afecta al ámbito tecnológico, empresarial, profesional y editorial de los médios de comunicación, propiciando una integración de herramientas, espacios, métodos de trabajo y lenguajes anteriormente disgregados, de forma que los periodistas elaboran contenidos que se distribuyen a través de múltiplas plataformas, mediante los lenguajes propios de cada una"
} 
A seara Tecnológica está relacionada à infraestrutura técnica, como computadores, câmeras, gravadores, servidores e sistemas de gestão de conteúdo “[...]para garantir a produção (redação integrada), a difusão cross-media e a recepção" (BARBOSA, 2009b, p. 4262). A tecnologia permitiu a criação de conteúdo em suportes digitais, é pelo viés tecnicista que se permitiu englobar várias mídias em um único suporte.

$\mathrm{Na}$ área Profissional, existe uma sinergia na elaboração de conteúdos para mais de um meio. Ela ocorre quando uma redação é unificada, ou redações independentes trabalham em sinergia na produção de conteúdo para diferentes plataformas. "Abarca, portanto, produção integrada, jornalistas polivalentes e distribuição multiplataforma" (BARBOSA, 2009b, p. 4262). São nestes casos que são elaboradas reuniões de pautas convergentes. Neste caso, há uma aceleração na produção, ampliação das responsabilidades e atuação em múltiplas áreas temáticas, executando tarefas diversificadas.

Já em relação à Empresarial, esta está totalmente relacionada à origem e à composição dos capitais que controlam os grupos midiáticos, sejam eles multinacionais, nacionais, regionais ou locais, e às alianças, fusões, participações societárias cruzadas, absorções ou novas empresas que resultam dessas composições. A última, a de Conteúdos, está voltada à criação de peças informativas mais inovadoras, explorando novas linguagens e narrativas, e ao uso de linguagem multimídia. Nesse ponto, há uma hibridização de gêneros jornalísticos.

Compreendemos que esses quatro âmbitos impulsionam transformações no processo de produção jornalística. "A tecnologia digital tem proporcionado a integração de funções no processo de produção informativa em distintos meios." (GARCÍA AVILÉS, 2006, p.36 ${ }^{27}$ ). Com isso, jornalistas têm assumido cada vez mais tarefas que antes eram separadas, feitas por funções distintas.

Estes pontos estão em consonância com a proposta de Barbosa (2009), do continuum multimídia, que nasce do artigo "The Convergence Continuum ${ }^{28}$ : A Model for Studying Collaboration Between Media Newsrooms”, de Dailey, Demo e Spillman, (2005). Os autores afirmam que a ausência de consenso sobre o conceito de convergência não impediu que a indústria midiática desenvolvesse equipes multimídias para produzir o que eles chamam de

\footnotetext{
${ }^{27}$ La tecnología digital ha propiciado la integración de funciones en el proceso de producción informativa en los distintos medios.

${ }^{28}$ Barbosa (2009) chama de "quinta-geração do jornalismo em rede". Por não concordarmos, não colocamos no texto. A ideia de quinta geração é desenvolvida a partir de sua tese de doutorado que delimitava o jornalismo feito na web [sendo a terceira geração proposta por Mielniczuk (2003), também conhecida como geração do webjornalismo, e quarta o Jornalismo Digital em Base de Dados, desenvolvida na tese]. Ao falar da quinta geração, centrando o desenvolvimento do jornalismo a partir da web, Barbosa ignora um ambiente mais complexo, convergente, ou dá a impressão de que as estratégias estão centralizadas no jornalismo feito na web.
} 
conteúdo convergente ou que as universidades modificassem seus currículos para incluir o treinamento de convergência.

\begin{abstract}
A convergência se caracteriza por um certo grau de interação e cooperação entre os parceiros cross-media, quer uma única empresa ou mais de uma possuam os meios. Posteriormente, propusemos um padrão comum de classificação - o modelo do continuum de convergência - e oferecemos definições de diversos níveis. Acompanhando pesquisadores como Tuchman (1978), este modelo se concentra na convergência à medida que esta se relaciona às rotinas das redações que determinam quais e como as histórias alcançarão o público. Tratamos a convergência de propriedade e a convergência tecnológica como forças distintas que, embora importantes, estão separadas das rotinas das redações. (DAILEY, DEMO e SPILLMAN, 2005 , p. 152$)^{29}$
\end{abstract}

O modelo de convergência proposto por Dailey, Demo e Spillman (2005) é dinâmico e foi dividido em cinco atividades de empresas de mídias. São propostas que podem variar de empresa para empresa. Também entendemos que, apesar de ser mais ampla, essa tipologia não exclui os quatro âmbitos da convergência propostos por Salaverría, García Avilés e Masip (2010).

O primeiro é a promoção cruzada (cross-promotion). Este é o modelo mais simples que uma redação pode adotar. Este padrão representa o uso de palavras ou elementos visuais para promover conteúdos produzidos por outros meios, sejam eles do mesmo grupo ou não. É comum encontrar nos noticiários da Rede Globo um apresentador que, ao finalizar uma matéria, informa que há mais informações no site do grupo. Não há a criação de uma nova informação e sim uma promoção do outro meio, buscando transpor a audiência de um espaço para o outro.

Clonagem de conteúdos é outra estratégia listada de convergência. Trata-se de um modelo bastante simples também, em que o conteúdo produzido por um meio é copiado em outro diferente. No Brasil, as versões de jornais na web nascem de transposição de conteúdos dos impressos (MIELNICZUK, 2003), numa clara estratégia de clonagem. $\mathrm{Na}$ contemporaneidade, a estratégia continua, mas "a seleção de informações é mais esmerada, e, sobretudo, se procura reciclar peças multimídia geradas por outras redações" (BARBOSA, 2009a, p. 8). Aqui também não há alterações do conteúdo do outro meio, apenas uma

\footnotetext{
${ }^{29}$ We start this article with the assumption that convergence is characterized by some degree of interaction and cooperation among cross-media partners, whether common or separate companies own the media. We further propose a common standard of classification - the convergence continuum model—and offer operational definitions of the various levels. Following such researchers as Tuchman (1978), this model focuses on convergence as it relates to newsroom routines that determine which and how new stories reach the audience. It treats ownership convergence and technological convergence as separate forces that, although important, are separate from newsroom routines.
} 
utilização. É o caso do portal G1, das organizações Globo, que utiliza vídeos feitos pelas várias edições do telejornal da emissora.

A terceira estratégia é a Coopetição (coopetition). Este tipo de estratégia funciona quando dois meios cooperam para compartilhar informação ou outros aspectos do negócio, ainda que sigam competindo ou, ao menos, produzam materiais originais próprios. Esta tática é adotada pelos meios para suportes nos quais não possuam nicho de mercado. Em grande eventos, como eleições, olimpíadas e desastres, é comum encontrar empresas midiáticas que competem unindo esforços para cooperar compartilhando informações ou outros aspectos do negócio. Para Barbosa (2009), "trata-se de um modelo mais evoluído que a promoção cruzada, na medida em que o redator convidado elabora uma peça para um meio que não é o seu".

A quarta estratégia é a distribuição multiplataforma. Aqui existe a exploração de conteúdos através de várias plataformas explorando as características de cada uma delas. É o chamado cross-media.

O quarto estágio deste modelo é o compartilhamento de conteúdo, ponto no qual um meio de comunicação regularmente (mas não sempre) compartilha informação coletada por seu parceiro cross-media e o publica após ter sido reformatado pelos membros da equipe desta organização. Os parceiros podem também compartilhar orçamentos de mídia e comparecer a reuniões de pauta um do outro. Colaboração em uma cobertura especial, investigativa ou empresarial é possível. Em geral, entretanto, as organizações de notícias produzem suas próprias histórias sem ajudar umas às outras (DAILEY, DEMO e SPILLMAN, 2005, p. 154)

Por fim, a integração completa, que seriam redações integradas (full convergence). O destaque desse modelo está em utilizar os pontos fortes de cada meio de comunicação para produção de conteúdos de forma eficaz: “Os times híbridos de jornalistas das organizações parceiras trabalham em conjunto para planejar, relatar e produzir as histórias, decidindo ao longo do trabalho quais partes serão contadas de modo mais efetivo no impresso, na TV e nas formas digitais" (DAILEY, DEMO e SPILLMAN, 2005, p. 154) ${ }^{31}$. As redações que

\footnotetext{
${ }^{30}$ The fourth stop on the model is content sharing, the stage at which a media outlet regularly (but not always) shares information gathered by its cross-media partner and publishes it after it has been repackaged by the organization's staff members. The partners also might share news budgets or attend the other partner's planning sessions. Collaboration on a special, investigative, or enterprise piece is possible. In general, however, the news organizations produce their own stories without helping each other.

31 "Under full convergence, hybrid teams of journalists from the partnering organizations work together to plan, report, and produce a story, deciding along the way which parts of the story are told most effectively in print, broadcast, and digital forms".
} 
trabalhavam de forma independente aqui passam a incorporar as estruturas de produção das empresas, passando a ter salas integradas, com coordenação editorial.

Esta fórmula está majoritariamente ligada à ideia de convergência e pode ser encontrada em diferentes graus em meios de comunicação. São níveis diferentes de convergência que podem evoluir ou não até a integração plena. Todas fazem parte do continuum multimídia, que é constituída pela medialidade (GRUSIN, 2010, p. 6). Nessa lógica, a produção jornalística é realizada por profissionais que se utilizam de tecnologias digitais em todos os processos de produção jornalística nas redações, também pela horizontalidade de produção e conteúdo. O ponto principal desse conceito é que não há mais oposição entre novos e velhos meios. Complementando a ideia de convergência, a ideia do 'novo' é rompida, bem como a ideia de concorrência entre os meios que integram um mesmo grupo jornalístico (BARBOSA, 2013).

A delimitação da medialidade perpassa pelo conceito de remediation (BOLTER, GRUSIN, 2000), que reconhece a influência de meio anterior para a construção de novos meios. Segundo os pesquisadores, uma nova mídia renova as formas de uma mídia anterior. Nesse processo, as "velhas mídias" (old media) são representadas e, em alguns momentos, destacadas pelas novas mídias, recebendo uma nova finalidade, uma nova forma e um novo tipo de acesso.

Os novos ambientes digitais não promovem mais uma oposição de meios como outrora mas, ao contrário, desenvolvem uma complementaridade e uma integração entre eles. A convergência exige uma nova linguagem que integre os meios anteriores, para que haja uma ação conjunta e organize processos e produtos, fora determinar a horizontalidade no processo de criação de conteúdo, o que resulta em um continuum multimídia de cariz dinâmico (BARBOSA, 2013).

Os processos de produção são agregados a fim de que se produza material para os diferentes tipos de plataformas, cada um com sua linguagem específica, os grupos de comunicação são reorganizados e surgem novas atribuições profissionais para que o jornalista, por fim, incorpore tecnologia e conteúdo (CANAVILHAS, 2012). O cenário proposto pela convergência não contempla mais a competitividade, mas a atuação conjunta para atrair mais leitores e reforçar a imagem da empresa.

Neste quadro, o surgimento de mídias móveis se mostrou de grande potencial para a exploração da prática jornalística. Os produtos informativos próprios levam à criação de aplicativos de conteúdo para tablets e smartphones e demandam uma nova prática de produção e consumo. Seu desenvolvimento é baseado em affordances específicas dos 
dispositivos móveis como a tactilidade e o lean-back (capacidade de captar a atenção por períodos maiores de tempo). A emergência desses produtos, obrigou a uma reorganização do processo produtivo nas redações, posto que exige uma narrativa diferenciada de outros meios.

Com esses vários canais possíveis de distribuição de notícias, parece estar se tornando uma tendência que as redações se integrem, assim como que as equipes se fundam em um mesmo espaço para facilitar a criação de conteúdo de forma cooperativa e amigável. Entretanto, o processo de integração ainda não é uma realidade em muitos veículos, de modo

que o espaço físico pode ser o mesmo, mas o fluxo de produção sofre percalços. Como se trata de uma novidade, a integração das redações é o ponto mais criticado na convergência das mídias, visto que requisita mudanças importantes na cultura jornalística e organizacional.

As redações integradas devem suprir os canais de um veículo com informações. Como cada meio exige um determinado tipo de narrativa, a equipe deve se adaptar para contar a notícia de diferentes formas. Esse processo é considerado como a futura realidade dos ambientes jornalísticos, dessa forma "as redações integradas estão sintonizadas com os fluxos multiplataformas das organizações jornalísticas no cenário de integração que se identifica como corrente nos modelos de negócios levando à redefinição da cultura da produção" (FIRMINO, 2013).

As organizações jornalísticas podem manter vários tipos de meios noticiosos vinculados a ela, quando estamos falando de convergência. Podem ser da mesma marca ou marcas diferentes. Como frisamos anteriormente, redações de veículos impressos, televisivos, radiofônicos, móveis e de web podem trabalhar em colaboração, sendo suas redações unificadas ou não.

\subsection{APROPRIAÇÕES DOS TABLETS E SUAS POTENCIALIDADES}

As apropriações e usos dos dispositivos móveis no cenário comunicacional são muito variados. São feitos em suportes digitais para leitura e escrita (eReader), como também em netbooks, telefones móveis e tablets (GÜERE E NEVES, 2012). É possível inserir, neste cenário de inovações, aplicativos, softwares e páginas web desenhadas especificamente para esses suportes. A partir de crescente interesse, as pesquisas sobre jornalismo e os dispositivos móveis emergem no século XXI com a propagação de conexões sem fio e tecnologias móveis mais avançadas - celulares, tablets, notebooks, entre outros (SILVA, 2008). 
O marco da inserção dos tablets no mercado é o mês de abril de 2010 quando a Apple lançou o iPad (CANAVILHAS; DE SANTANA, 2011). Os suportes não eram novidade no mercado da tecnologia, porém o lançamento de Steve Jobs representou um boom de vendas, atestando a grande aceitação do aparelho no mercado mundial. Já a utilização do suporte para a prática jornalística é anterior ao lançamento da Apple, com o 'tablet newspaper' há 17 anos, em 1997. O professor e diretor do programa Digital Publishing Donald W. Reynolds Journalism, da Universidade do Missouri (EUA), Roger Fidler, é o idealizador do dispositivo (BARBOSA, SEIXAS, 2013).

Projetos jornalísticos foram lançados, marcando a exploração dos recursos nativos das novas plataformas: o norte-americano The Daily, o italiano La Repubblica Sera, o belga Le Soir e o espanhol El Mundo de La Tarde. No Brasil, O Globo a Mais, de O Globo, e Estadão Noite, de $O$ Estado de S. Paulo, são destaques. O jornalismo feito para esse tipo de plataforma é chamado de tabletjornalismo (DA CUNHA e FREIRE, 2017, no prelo) e segue a mesma lógica do webjornalismo, telejornalismo ou radiojornalismo. Assim, todo trabalho feito para ser publicado nos tablets é chamado de tabletjornalismo. Compreendemos que este tipo de jornalismo privilegia o suporte para o qual as informações são trabalhadas e por isso temos ressalvas em utilizar o termo. Os tablets fazem parte da estratégia das industrias jornalísticas e foram vistos pelas empresas como um novo suporte para a produção de conteúdo e uma alternativa comercial a ser explorada (VALENTINI, 2012).

"No campo do jornalismo e das práticas de comunicação contemporâneas, observa-se que o jornalismo cada vez mais se alimenta de plataformas móveis, tanto para a produção, quanto para a difusão de conteúdo digital” (RUBLESCKI; BARICHELLO; DUTRA, 2013, p. 129). Empresas jornalísticas têm desenvolvido aplicativos, mas a web também tem sido utilizada, com apoio de uma linguagem chamada de HTML5, como suporte de produção desse formato.

Barbosa e Seixas (2013, p. 62) acreditam que as aplicações tablet-based media seguem a mesma tendência das primeiras versões de sites jornalísticos para a web. As pesquisadoras afirmam que vivemos um "estágio de transposição pura e simples, que emula as edições impressas de jornais e também de revistas". Porém, essas transposições no cenário midiático são mais complexas e provenientes de diferentes suportes. Elas mostram que são agregados "conteúdos multimídia dos respectivos sites para os novos dispositivos tablets como iPad, Xoom, HP touchPad ou aqueles que rodam o sistema android da Google."

É nitidamente perceptível que os "processos visuais, sonoros e textuais que permeavam os meios tradicionais de comunicação são gradualmente incorporados aos 
dispositivos móveis, inclusive para fins noticiosos-jornalísticos”, observaram Rublescki, Barichello e Dutra (2013, p. 121). Nos aplicativos para tablet, a criação de hipertextos passa a acontecer em um ambiente fechado; ao usar links externos, o jornalista leva o usuário a um ambiente externo. Certamente essa decisão pesa na hora da escolha por uma linguagem hipermidiática.

\subsubsection{Mapeando a realidade brasileira: da expansão ao declínio}

Os dispositivos móveis, como celular e tablet, foram adotados pelos jornais como uma das alternativas de rentabilização em meio à crise empresarial em que estão inseridos. Quando comparados a outros suportes, sua rentabilização é mais plausível (AGUADO, CASTELLET, 2013), principalmente por serem, na maioria dos casos, uma plataforma fechada ${ }^{32}$, sem livre circulação de conteúdo na rede. Também pelo diminuição na produção de conteúdo, que passa a ser cross-media, pelas novas formas de interação com os usuários e a fidelização das audiências mais jovens. "Em termos jornalísticos, as palavras de ordem são reinventar o formato das notícias e diferenciar o conteúdo, além de personalizar a experiência de leitura em mobilidade" (RUBLESCKI, BARICHELLO, DUTRA, 2013, p. 129)

Palacios e Cunha (2012) acreditam que a crise pela qual passa a indústria jornalística pode ter efeitos alternativos e opostos quanto ao ritmo de incorporação dos novos recursos dos tablets, que seriam:

a) criar um maior retardamento, por falta de investimentos disponíveis, para pesquisa e experimentação, ou; b) provocar uma aceleração, através da busca de novos modelos de negócios e formas novas de tornar lucrativas as empresas de comunicação, com utilização de plataformas e formas de apresentação de informação renovadas e tecnologicamente arrojadas, com o fito de atrair usuários dispostos a pagar por produtos e serviços jornalísticos diferenciados (PALACIOS e CUNHA, 2012, p 682).

Uma outra possível explicação para o desenvolvimento inicial dos aplicativos jornalísticos está nos dados da expansão do mercado de vendas e consumo, que vinham crescendo a cada ano. Dados da ComScore ${ }^{33}$ mostram que a proporção de acessos realizados

\footnotetext{
${ }^{32}$ As versões de informativos para tablets que possuem aplicativos precisam descarregar a versão do jornal para ser acessadas. Esse acesso se dá por meio de assinatura ou compra avulsa da edição.

${ }^{33}$ Informação disponível em: < http://m.folha.uol.com.br/tec/2012/08/1137021-participacao-de-tablet-e-celularna-internet-brasileira-quadruplica-em-um-ano.shtml $>$
} 
por dispositivos móveis, como celulares e tablets, teve crescimento de $300 \%$ entre maio de 2011 (quando era de $0,6 \%$ do tráfego total) e maio de 2012 (2,4\%) no Brasil. Somente nos três primeiros meses de 2012, 493 mil tablets foram vendidos no Brasil. No primeiro trimestre de 2013, a venda cresceu 164\% em comparação com o mesmo período do ano anterior, alcançando 1,3 milhão de aparelhos vendidos

No mundo, a retração mundial começou a dar sinal em 2014. O número foi pequeno: 2\%, o que representa cerca de 9,3 milhões de unidades, certificou a IDC Brasil. Contudo, em 2015, a venda dos aparelhos caiu 12,6\% no terceiro trimestre, segundo estimativas do IDC. Este ano é o marco indicado pelo instituto como um mercado "em transição", que enfrenta o sucesso dos smartphones com tela maior (os phablets ${ }^{34}$ ).

Em julho de 2013, utilizando a observação livre (TRIVIÑOS, 2011), registramos que existiam no Brasil 141 veículos com versões para tablets (Associação Nacional de Jornais/ANJ, $2013^{35}$ ). Feito esse primeiro levantamento, ancorado no trabalho de Güere e Neves (2012), e identificadas algumas apropriações distintas, desenvolvemos uma tipologia e passamos a categorizar as versões para dispositivos em:

a) Transpositivos: disponibilizam o PDF do impresso, transpondo o conteúdo original.

b) Transpositivos híbridos: transpõem conteúdos dos diversos meios do grupo de comunicação. Além disso, esses dispositivos podem apresentar versões do impresso, potencializando-o com recursos interativos, multimidiáticos e hipertextuais, como links e QR Codes $^{36}$.

c) Autóctones: nascem exclusivamente para o suporte e possuem uma produção exclusiva.

Um outro aspecto que precisa ser deixado claro é que nosso foco e busca, neste levantamento, era por aplicativos direcionados à produção de conteúdos jornalísticos noticiosos. Frisamos isso porque as empresas jornalísticas têm criado aplicativos

\footnotetext{
${ }^{34}$ São celulares inteligentes com telas maiores, entre 5,5 e 7 polegadas. Os aparelhos reúnem tanto os recursos de um smartphone quanto de um tablet.

${ }^{35}$ Para construir a metodologia desta pesquisa, escolhemos visitar as páginas da internet dos associados buscando descobrir quais possuíam versões para tablets. A procura foi realizada na página principal de forma visual e utilizando as seguintes palavras-chave na busca: tablet, ipad e móvel. Essas palavras foram escolhidas a partir de uma observação inicial para a identificação das mais usadas. Além disso, de forma complementar, fomos à loja virtual da Apple e utilizamos o nome do veículo para encontrar o aplicativo. Essa busca foi feita no mês de junho de 2013.

${ }^{36}$ A sigla significa resposta rápida (Quick Response). Trata-se de um código de barras, criado em 1994, que possibilita ser interpretado por sistemas para dar acesso a novas informações.
} 
diversificados, como para entretenimento (infoTabment), prestação de serviço e outros puramente jornalísticos. Com isso, é possível encontrar em meios de comunicação mais de um aplicativo. Outro ponto que destacamos é que há aplicativos feitos em lojas específicas de apps, como a da Apple, bem como versões para o dispositivo desenvolvidas na web.

Além disso, para identificar os aplicativos que possuíam produção específica para o suporte, analisamos a primeira capa das versões com a página web. Esses dados foram levantados de 9 a 15 de junho de 2013, totalizando uma semana de observação. Nossos dados mostram que, na região Sudeste, dos 66 jornais sócios da ANJ, 18 possuem suas versões em aplicativos para tablets. Desses, 16 possuem aplicativos próprios e dois vendem versões impressas no aplicativo O Jornaleiro. Usando nossa tipologia, é possível afirmar que existem 12 aplicativos transpositivos, dois transpositivos híbridos e dois autóctones. Apenas um dos jornais tem uma versão para tablet na web, que é a Folha de S. Paulo, e também tem aplicativo nas lojas. Todos os dispositivos apresentam modelos de assinatura variados.

Somente o jornal $O$ Globo, em um dos suas aplicativos, o $O$ Globo A Mais, possui conteúdo produzido exclusivamente para o suporte. $\mathrm{O}$ aplicativo Estadão Noite foi desenvolvido para o suporte, mas absorve boa parte do conteúdo de outros meios do grupo. Os dois seriam dispositivos autóctones. Além disso, o jornal Lancer oferece uma versão do seu jornal impresso com potencializações, como o leitor de QR Code. Além disso, a Folha de S. Paulo oferece recursos utilizados na web. Nesse caso, além de ter conteúdo autóctone, ele também pode ser considerado um transpositivo híbrido.

Conforme Tabela 1, na região Sul, dos 28 jornais associados, dez possuem aplicativo na Appstore, sendo todos eles transpositivos. Desses, dois jornais, do mesmo grupo empresarial, utilizam um mesmo aplicativo. Dos 15 jornais da região Norte, apenas dois têm aplicativos. São modelos transpositivos e também adotam o formato pago. Para ter acesso ao PDF da versão impressa, o usuário precisa assinar um plano.

Na região Nordeste, dos 23 jornais, apenas quatro possuem aplicativos. Um deles, o Jornal da Paraíba, tem aplicativo para diferentes plataformas e dá acesso via web também. No período de nossa pesquisa, o Estado do Maranhão apresentou erro: ao clicar na chamada de capa do site, não foi possível abrir o aplicativo; tampouco foi encontrado na loja. O Diário do Nordeste, com seu aplicativo Diário do Nordeste Plus, é autóctone, sendo o único fora da região Sudoeste. A versão também mostrou sucessivos erros.

Já na região Centro-Oeste, são nove jornais associados. Desses, apenas dois possuem aplicativos. O Correio Braziliense tem um transpositivo híbrido. O jornal O Popular, uma 
versão transpositiva. Além desses dois, o Jornal de Brasília oferece apenas suas versões do impresso em PDF no aplicativo O Jornaleiro.

\begin{tabular}{c|c|c|c|c|c} 
& Sudeste & Sul & Norte & Nordeste & $\begin{array}{c}\text { Centro- } \\
\text { Oeste }\end{array}$ \\
\hline Transpositivos & 12 & 10 & 2 & 3 & 2 \\
\hline Transpositivos híbridos & 2 & 0 & 0 & 0 & 1 \\
\hline $\begin{array}{c}\text { Autóctones } \\
\text { Total de Jornais com } \\
\text { aplicativos }\end{array}$ & 16 & 10 & 2 & 4 & 3
\end{tabular}

TABELA 1 - Aplicativos de jornais divididos por região (produção nossa).

Apesar de ainda serem tímidas as apropriações e o desenvolvimento de versões jornalísticas nativas (MARQUES, 2014a) há, de alguma forma, uma ascensão desse tipo de apropriação quando olhamos para os dados coletados. Como mostramos acima, esse crescimento era justificado também pelas pesquisas de mercado, que apontavam que o número de acesso por esses dispositivos aumentava a cada ano. Nos Estados Unidos, os números também chamavam atenção. Das pessoas que possuem tablets no país, $64 \%$ usavam o dispositivo para ler notícias, revelou a Pew Research Center's Project for Excellence in Journalism (PEJ) ${ }^{37}$.

Com intuito de atualizar os dados sobre desenvolvimento de aplicativos para tablets de nossa pesquisa e testar uma possível diminuição do investimento em aplicativos, voltamos a fazer a análise no período de 09 a 17 de dezembro de 2016 (ANJ, 2016). Ao total foram 120 veículos avaliados, o que já representa uma queda de 20 associados, quando comparado à observação anterior. Todas as páginas dos associados da ANJ foram visitadas com o intuito de apurar se os veículos possuíam versões para tablets. Além disso, utilizamos a ferramenta de busca na loja da Apple e procuramos o nome do meio de comunicação para encontrar o aplicativo.

\footnotetext{
${ }^{37}$ Dados disponíveis em: <http://www.journalism.org/2012/10/01/future-mobile-news/>
} 
Conforme Tabela 2, fizemos a separação dos veículos por região, contabilizando 13 jornais na região Norte, 21 jornais no Nordeste, sete no Centro-Oeste, 54 no Sudeste e 25 na região Sul. Feita a separação por região, contabilizamos por Estado: Amazonas (4), Alagoas (1), Amapá (1), Bahia (3), Ceará (2), Distrito Federal (2), Espírito Santo (4), Goiás (1), Maranhão (2), Mato Grosso (1), Mato Grosso do Sul (3), Minas Gerais (7), Pará (4), Paraíba (2), Paraná (9), Pernambuco (4), Piauí (2), Rio de Janeiro (11), Rio Grande do Norte (2), Rio Grande do Sul (11), Rondônia (2), Roraima (1), Santa Catarina (5), São Paulo (32), Sergipe (3) e Tocantins (1).

Após a concretização dessas duas etapas, foi feita a verificação individualizada de cada veículo de comunicação. Nossos dados mostram que na região Norte, dos 13 jornais sócios da $\mathrm{ANJ}$, cinco possuem suas versões em aplicativos para tablets e oito, não. Desses oito, dois jornais já disponibilizaram esse recurso no passado, porém, ele foi descontinuado são o Diário Dez Minutos e o Diário do Amazonas. Os seis restantes jornais são transpositivos.

Na região Nordeste, dos 21 jornais, 13 possuem aplicativos. Um deles, o Jornal da Paraíba, encerrou as atividades na versão impressa em 10 de abril de 2016 e teve prosseguimento com conteúdo digital e com o aplicativo para tablet. Dos dispositivos, 12 são transpositivos. O Centro-Oeste conta com apenas sete jornais associados; desses, quatro possuem aplicativos. O Correio Braziliense tem um transpositivo híbrido; os demais são apenas transpositivos.

Na região Sudeste, dos 54 veículos associados à ANJ, 28 possuem suas versões em aplicativo para tablets. Um dos associados, o jornal O Debate, sugere a Nuvem do Jornaleiro como aplicativo, que funciona como uma banca digital. A Folha de S. Paulo é considerada um transpositivo híbrido, pois oferece recursos utilizados na web e apresenta modelos variados de assinaturas. Já os outros aplicativos são considerados transpositivos, totalizando 21. Na região Sul, dos 25 jornais associados, 17 possuem aplicativo na AppStore. O jornal Zero Hora é considerado um transpositivo híbrido, pois oferece recursos variados ao usuário, além do conteúdo em PDF. Ao todo, 12 são considerados transpositivos. 


\begin{tabular}{c|c|c|c|c|c} 
& Sudeste & Sul & Norte & Nordeste & $\begin{array}{c}\text { Centro- } \\
\text { Oeste }\end{array}$ \\
\hline Transpositivos & 21 & 12 & 7 & 12 & 3 \\
\hline Transpositivos híbridos & 1 & 1 & 0 & 0 & 1 \\
\hline Autóctones & 0 & 0 & 0 & 0 & 0 \\
\hline $\begin{array}{c}\text { Total de Jornais com } \\
\text { aplicativos }\end{array}$ & 22 & 13 & 7 & 12 & 4
\end{tabular}

TABELA 2 - Aplicativos de jornais divididos por região (produção nossa).

Como a convergência jornalística é um processo em evolução contínua, de cariz complexo, o desenvolvimento de pesquisas que estudem casos distintos, de regiões diferentes, para conhecer as rotinas de produção em redações integradas, permitirá esclarecer as formas da convergência jornalística no Brasil, seus modelos, como é o desenvolvimento e implantação das ações relativas às distintas áreas da convergência jornalística e o grau de convergência existente (BARBOSA, 2009a, p. 51).

Ao contrário de outros meios digitais, os equipamentos utilizados diferenciam e definem as características de acesso a notícias, como computadores de mesa ou dispositivos móveis como tablets e smartphones. Apesar de existirem diversas usos, interessam-nos as apropriações nativas para o suporte tablet. Mais especificamente, lançamos um olhar sobre os vespertinos brasileiros: O Globo A Mais, Diário do Nordeste Plus e Zero Hora. Principalmente para averiguar se as especificações dessas versões impactam o processo de produção da pauta jornalística.

\subsubsection{Rotinas de Produção para Tablets}

Antes de começarmos a elencar as rotinas no contexto dos tablets, listamos algumas características que precisam ser levadas em conta para a produção da informação. A primeira diferença dos outros suportes tradicionais é a mobilidade, que estende ao espaço público o consumo das notícias e a forma de produção de conteúdo, criando o que Lemos (2007) chama de territórios informacionais. Os usuários passam a dispor das informações em telas, nos 
metrôs, ônibus, em estado de deslocamento. Essa característica pode influir na leitura dos textos e nos formatos que são buscados.

Um segundo ponto, que está imbricado com o primeiro, é a portabilidade, que modifica as condições de leitura, voltando a aproximar-se do manuseio do impresso, e alterando, com isso, a produção e formatação do conteúdo. Outra característica tem relação com a forma de manusear com os dedos a interface do dispositivo, funcionalidade conhecida como touch. Apesar de outros dispositivos apresentarem essa características, é o tablet o primeiro a consolidar a leitura de notícia com tal função.

O conteúdo estar hospedado em um aplicativo também é um diferencial. Muitas edições e serviços jornalísticos para tablets são desenvolvidos em programação eletrônica. Esse desenvolvimento abre novas perspectivas de modelo de negócio para os meios de comunicação e gera renovadas demandas no processo produtivo de informações. Há empresas midiáticas que têm desenvolvido produtos jornalísticos não somente em aplicativos. A web também tem sido utilizada, com apoio de uma linguem HTML5, como suporte de produção desse formato.

Esse desenvolvimento herda do webjornalismo caraterísticas passíveis de uso, como hipertextualidade, multimidialidade, personalização (BARDOEL; DEUZE, 2002), atualização contínua/instantaneidade e memória (PALACIOS, 2003). É neste ponto que florescem debates teóricos acerca do tema. Neste ponto, observaremos como essas apropriações estão sendo usadas. Com o uso dos tablets e telefones celulares, Palacios e Cunha (2013) propõem o surgimento de uma nova característica desse jornalismo: a tactilidade. Há também que se destacar que os aplicativos jornalísticos têm utilizado imagens em alta definição (high definition). Os vídeos também possuem em sua grande maioria alta qualidade. (MARQUES, 2014b). De alguma forma isso acaba impactando na geração de conteúdo para o suporte.

Apresentadas algumas das características, passamos a adentrar as rotinas produtivas. De acordo com Wolf (2003), a coleta é proporcional aos recursos disponíveis. Disponibilidade de recursos humanos e materiais fazem parte do rol de necessidades para produção da informação jornalística nesta etapa. O primeiro passo da coleta se dá na escolha dos temas que serão abordados. É o momento em que se inicia a pesquisa ampla dos temas e acontecimentos possíveis do dia para depois o jornalista avaliar a viabilidade das peças. É no emaranhado de fatos que os editores buscam as temáticas que serão manchetadas no dia. Nasce, a partir desse ponto, a pauta que será debatida em reunião.

Selecionado o tema que será destaque na edição do dia, a construção da pauta passa a ser um elemento central na primeira etapa. Pauta pode ser descrita como uma agenda ou 
roteiro dos assuntos abordados. Para Rabaça e Barbosa (2001, p.556), pode ser também uma "súmula de matérias a serem feitas em determinadas edições" ou um planejamento esquematizado de angulações a serem usadas em um texto jornalístico. No caso do jornalismo digital, quando a produção é multimidiática, a pauta, além de ser um roteiro e um recurso interpretativo mental, é uma ferramenta para composição da narrativa (SCHWINGEL, 2012). Certamente essa dinâmica também funciona nos tablets.

No cenário de uma redação convergente, a apuração começa nos primeiros meios dos grupos escolhidos para divulgar a informação: rádio, televisão, portais e os perfis nos sites formadores de redes sociais on-line. A decisão quanto ao conteúdo que circulará no tablet acontece durante a reunião de pauta. Contudo, nem todas as redações são integradas, é o caso do extinto O Globo A Mais (MARQUES, 2015). No caso desse vespertino do jornal O Globo, as reuniões de pauta aconteciam em dias específicos e os editores davam a palavra final.

Em $O$ Globo, que edita $O$ Globo a Mais, por exemplo, a primeira reunião de pauta, que é de meio, acontece às $8 \mathrm{~h}$ da manhã e dessa reunião nasceria o conteúdo a ser publicado ou é inicialmente pautado. Este é um trabalho circular, que está integrado aos valores-notícia e aos canais/ fontes da informação (MARQUES, 2015). "Os dois processos procedem quase simultaneamente, visto que a coleta ocorre sobretudo por meio de fontes estáveis, que tendem a fornecer material informativo já facilmente inserível nos procedimentos produtivos normais da redação" (WOLF, 2003, p. 230). Contudo, eles podem surgir também de fontes não estabilizadas, como acontecimentos do dia a dia. Acreditamos serem esses os primeiros fatores para estabelecer a viabilidade daquilo que se torna um produto jornalístico.

A decisão sobre quais assuntos entrarão no dia hoje perpassa as métricas geradas por softwares da $w^{3} b^{38}$ e a repercussão gerada pela propagação das informações. Essa escolha deve ser tomada não só pelos critérios tradicionais, como o valor-notícia. Compartilhamento em redes sociais na web, sistemas de mensuração de palavras-chave e número de acessos dos meios digitais são outros índices que passaram a influenciar a publicação. A seleção das notícias ganha assim um novo critério sócio-métrico, e isso é essencial para o conteúdo de um vespertino. As informações que têm circulado nos vespertinos são fatos que ganharam destaque durante o dia. Por isso, a apuração ocupa boa parte da jornada dos profissionais, que devem trazer novas angulações e informações ainda não abordadas.

Passado o momento da reunião de pauta, o jornalista passa a coletar informações que serão usadas na redação do material e, mais tarde, na edição. As entrevistas são feitas em

\footnotetext{
${ }^{38}$ Google Analytics e Chartbeat
} 
equipamentos digitais para que, na hora da edição, o repórter escolha o formato que usará. Com isso, quando a presença física é permitida, os vídeos são privilegiados. Geralmente, as imagens são capturadas com máquinas profissionais (MARQUES, 2015). Há, nas versões autóctones, espaços para galerias de imagens e elas são usadas em todas as matérias. Em trabalho anterior (MARQUES, 2015), observamos que a maioria dos arquivos utilizados são de agências noticiosas e de assessorias de imprensa. Apesar de não fazer parte da lógica dos vespertinos ainda, acreditamos que os dispositivos móveis acrescentam novos critérios de noticiabilidade, como localismo e instantaneidade intensiva (SILVA, 2007).

Silva (2008, p. 2) explica que a ideia de geolocalização via GPS nas notícias reforça a ideia de localismo, do hiperlocal, ou visualização espacial da notícia. "Este é um elemento novo no jornalismo que acrescenta novas informações à matéria numa construção que une instantaneidade e localização geográfica". Apesar de existir essa potencialidade, nas versões vespertinas não se faz uso sistemático da geolocalização para customização da informação. Notícias são produzidas, como já frisamos, na "lógica do a mais", com informações aprofundadas, análises, mas não houve o emprego de geolocalização para enriquecer a experiência do leitor.

Há de se ressaltar que as plataformas feitas para tablets aportam ferramentas oriundas de outros meios de comunicação e que demandam um conhecimento amplo de diversos suportes. Há uma tendência no mundo, por exemplo, de coberturas ao vivo, via streaming, em muitos jornais. Na fase de edição, as funções inseridas nas matérias são testadas. Recursos interativos e multimídia são repassadas pelo editor. São checados também os conteúdos, e todo o processo de apuração é conferido, além de ser feita uma leitura do texto e uma possível padronização com o manual da empresa.

A última etapa, de circulação, os designers se colocam como os responsáveis. Além das informações essenciais ao conteúdo noticioso, como nome do repórter, editor, data, prazo de entrega, assunto, histórico/assunto, enfoque do texto, desdobramento e fontes, abre-se atualmente a necessidade de se pensar nos formatos utilizados e no fluxograma do texto. Schwingel (2012) acredita que é possível também inserir elementos interativos no texto.

Até o momento, as experiências jornalísticas no mundo e no Brasil são tímidas e regrediram bastante com a substituição do aparelho por outras versões. A explicação está, inicialmente, no fato de ser uma nova plataforma. Barbosa e Seixas (2013) afirmam que vivenciamos uma nova fase transpositiva dessas versões, seguindo a mesma tendência das primeiras edições de sites jornalísticos para a web. Em 2014, surgiram plataformas com 
produção exclusivas contudo, o que encontramos em 2016 é pura transposição do imprenso, com uma rara exceção do Zero Hora Noite, que é um híbrido. 


\section{CAPÍTULO IV}

\section{A EVOLUÇÃO DA PAUTA E SEUS ASPECTOS}

A elaboração da pauta é um processo comum nos meios de comunicação, seja na imprensa escrita, no rádio, na televisão, na internet, seja nos dispositivos móveis. Sua adoção nas redações jornalísticas tem início no período de transformação dos jornais em empresas, como discutido no capítulo II. Desde princípios do século XX, a revista Time, por exemplo, já produzia pautas e realizava reuniões para apresentação delas (LAGE, 2001; JORGE, 2008a).

No Brasil, a pauta começou a ser utilizada nos jornais diários com a reforma gráfica, feita pela Última Hora e pelo Diário Carioca, no Rio de Janeiro, na década 1950 (LAGE, 2001). Em termos de estruturação, os padrões que mais se aproximariam do modelo usado nas redações da contemporaneidade foram inicialmente adotados no Jornal do Brasil.

Apesar de destacar que a utilização da pauta começa no Rio de Janeiro, Lage (2001) afirma que esse processo somente vai se generalizar com a modernização do jornalismo brasileiro, que ocorre a partir de São Paulo, na década de 1970. Então, “a pauta foi introduzida por toda parte, junto com as técnicas de redação, a programação gráfica das páginas e os procedimentos gerenciais que caracterizam a imprensa industrial moderna" (LAGE, 2001, p. 32).

A pauta nasce principalmente como uma estratégia empresarial e segue a mesma lógica evolutiva de desenvolvimento e consolidação do jornalismo e de suas rotinas (ver tópico 3.2). "A pauta, no jornalismo, é o primeiro processo que estabelece uma organização para o caos dos fatos do mundo", reconhece Bernardes (2003, p. 3). Ela é adotada ao mesmo tempo em que despontam as novas técnicas de redação - como a introdução do lide e de normas de escrita jornalística -, a programação gráfica das páginas e os procedimentos gerenciais que deram feição à imprensa moderna (LAGE, 2001).

Antes de a utilização da pauta ser uma regra, apenas os principais conteúdos, que eram de interesse da direção do jornal, eram programados de forma sistemática. Para os jornalistas, a pauta também representou o primeiro passo de uma ordenação mais concisa de suas próprias práticas e dos padrões de produção textual. Ela pode ser considerada como um dos trabalhos mais importantes do processo de produção das edições jornalísticas (GREENE- 
GONZÁLEZ, LECAROS-MENÉNDEZ, 2015), justamente por essa sua função de organizar e sistematizar os trabalhos.

Enquanto conceito operacional deste trabalho, partimos da compreensão da pauta como roteiro ou agenda - oral ou escrita - dos principais assuntos a serem abordados na edição de um meio de comunicação noticioso (LUZ, 2005b) e que perpassa todo o processo produtivo. Com isso, afirmamos que ela não é uma etapa estanque do processo de produção. É um objeto vivo que permeia todas as etapas de produção e edição de notícias e vai evoluindo durante todo o desenrolar do trabalho de uma equipe jornalística, até desembocar na circulação do produto final.

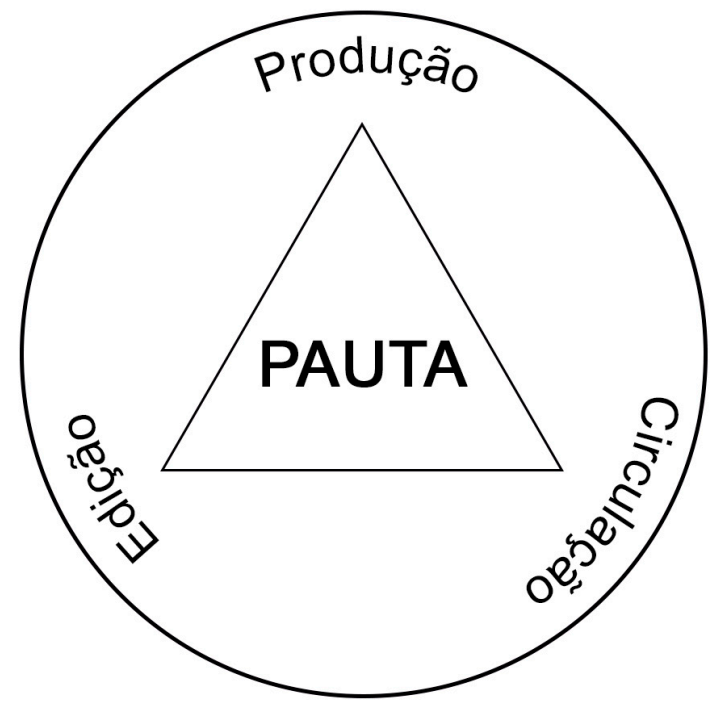

GRÁFICO 7 - A pauta está no centro do processo de produção (produção nossa).

A pauta constitui primeiramente o ponto de partida do processo de produção jornalística. "Muitas vezes, a pauta é simples ordem de serviço: cobrir um acontecimento, entrevistar alguém" (O GLOBO, 2001, p. 13). Muitos manuais (FOLHA DE S. PAULO, 2001; O GLOBO, 2001) também indicam que ela jamais deve ser uma camisa-de-força, inibidora de novos enfoques e olhares à temática a ser coberta. Por isso, ao propormos nosso conceito operacional, afirmamos que a pauta só será concretizada depois que o conteúdo é produzido e circula.

Vamos tratar a seguir de alguns aspectos fundamentais para a compreensão da pauta como elemento fundamental das rotinas produtivas no jornalismo. Abordaremos tópicos importantes como a origem das pautas, sua destinação e motivo, o enfoque e a estrutura. 


\subsection{ORIGEM DAS PAUTAS}

A pauta não é um produto de ficção. Ela é originada de um olhar atento ao mundo. O trabalho com as fontes de informação, a leitura diária de publicações impressas e eletrônicas dão origem a possíveis pautas (FOLHA DE S. PAULO, 2001). O Manual de redação da Folha de S. Paulo (2001) afirma que as pautas são desenvolvidas pela observação da vida na cidade, pela reflexão sobre os acontecimentos, sejam eles nacionais, sejam internacionais. São fruto também de uma constante capacidade de o jornalista se manter inteirado e curioso, bem como da suspeição permanente em relação a tudo que seja consensual ou habitual. Nasce ainda da capacidade de interpretar e cruzar dados. Por fim, ao utilizar todos esses aspectos elencados, uma ideia de pauta floresce a partir da percepção do que seja interessante, útil ou válido para a informação e o entendimento do leitor.

Nesse regime de proposituras, cada meio de comunicação estabelecerá suas hierarquias para selecionar os assuntos. Na Folha de S. Paulo (2001), a título exemplificativo, assuntos "incontestáveis" e notícias de utilidade pública ocupam o topo da hierarquia. Temas que podem alterar estruturas econômicas, políticas e culturais de uma cidade são exemplos de matérias "incontestáveis", já as que afetam o cotidiano são de utilidade pública. Independentemente do raciocínio assumido pelos meios, "o critério que deve imperar no momento de ordenar a pauta é o de considerar não apenas a origem da informação, mas também o alcance de suas repercussões e sua relação com o restante das notícias que a acompanham" (DE FONTCUBERTA, 2014, p. 5 e 6, tradução nossa) ${ }^{39}$.

Para a maioria dos veículos de comunicação, a pauta pode começar a ser feita no fechamento da edição anterior ou no começo do dia e sofre diversas alterações durante o processo de produção até a circulação. São as periodicidades dos veículos de comunicação que vão delinear o momento de criação de novas pautas. Em alguns veículos, como o Correio Braziliense e $\mathrm{O}$ Estado de $\mathrm{S}$. Paulo, existe a pré-pauta, que dá início à rotina de trabalho do jornal, mas isso se aplica também a meios televisivos e de rádio. A pré-pauta é uma lista de pontos enumerados e exige uma "pesquisa inicial para virar pauta" (JORGE, 2008a; PINTO,

\footnotetext{
39 “el criterio que debe imperar a la hora de ordenar la pauta es el de considerar, no sólo el origen donde se produce la información, sino el alcance de sus repercusiones y su relación com el resto de las noticias que la acompañan."
} 
2008, p. 67). A estruturação e o conteúdo concreto, com fontes indicadas, diferenciam a prépauta de uma pauta consolidada.

Não levamos em consideração a pré-pauta neste trabalho porque sempre será difícil delimitar o nível de apuração, enquadramento, fontes utilizadas, hipóteses, perguntas a serem respondidas para considerar uma pauta consolidada. Por isso, para a nossa pesquisa, não diferenciaremos pauta de pré-pauta. Entendemos, na verdade, que a pauta funciona de forma dinâmica e que vai se desenvolvendo ao longo do trabalho do jornalista. Ela só se consolida no final da edição, no caso de jornais impressos, televisivos e radiofônicos, quando esta começa a circular para a audiência em formato de matéria jornalística.

Para os meios instantâneos, que trabalham em tempo real, ela torna-se mais fluida porque matérias são publicadas e atualizadas constantemente. O que há, muitas vezes, é uma programação mínima de cobertura e a partir disso, com o desenrolar do dia, notícias vão sendo inseridas no sistema e controladas pelo editor que fica na redação do periódico. Isso ocorre porque a pauta é, em muitos casos, modificada ao longo de todo o processo de produção jornalística. Interessa-nos, portanto, observar os desdobramentos da pauta até sua consolidação final.

\subsubsection{O pauteiro}

As pautas não surgem do nada e os diversos profissionais que fazem parte da redação podem sugerir a pauta. O repórter, durante o seu dia a dia, ou mesmo em uma cobertura, pode descobrir algo novo ou cruzar com outras informações para sugerir temas e enfoques. Os editores também propõem pautas, que podem surgir de desdobramentos de temas, com uma nova abordagem sobre um fato. Os pauteiros, por muitos anos, tiveram exclusividade nessa função; contudo, na maioria das redações nacionais essa função, se não desapareceu, encontra-se em processo de extinção. O pauteiro é o responsável por novos temas ou por abordagens diferenciadas de uma informação que os meios de comunicação vinham cobrindo ou não. "O pauteiro generalista sempre oferecia uma visão mais abrangente, facilitando a compreensibilidade das matérias por parte de um público extremamente heterogêneo" (LUZ, 2005b, p. 101).

O cronograma dos eventos que seriam cobertos no dia é de responsabilidade desse profissional. Ele atribuía pautas aos repórteres e mantém contato com eles durante o dia para 
checar a apuração. Ele servia também como uma nova perspectiva quanto a abordagens e apurações. Ele trabalhava mais próximo de um repórter se o repórter é menos experiente, se está trabalhando em uma pauta controversa ou se a pauta tiver vindo de altos escalões do veículo. (ERICSON, BARANEK, CHAN, 1987, p.97)

Ao pauteiro cabia ler tudo que chegava às suas mãos, sempre na expectativa de encontrar ou pensar em uma boa matéria jornalística. "Quantas reportagens não se inspiraram em modestíssimos anúncios classificados, que o anônimo leitor deixa no balcão e manda publicar, mediante o pagamento de poucos cruzeiros?" (ERBOLATO, 1991, p. 177).

A função de pauteiro, todavia, apesar de pouco existir como um cargo específico, permanece sendo exercida pelos diversos profissionais que a executam no dia-a-dia. “Atualmente repórteres, editores, repórteres-fotográficos passaram a realizar essas funções nas reuniões de pauta. [O pauteiro] é o criador, inventor de sugestões para as próximas edições" (RABAÇA, BARBOSA, 2001, p. 556).

$\mathrm{Na}$ atualidade, em muitas redações integradas, pauteiros recebem o nome de produtores. Os departamentos de produção foram criados na busca de os meios jornalísticos trazerem uma cobertura mais atraente e diversificada. A ideia principal era não ficar refém das fontes estabelecidas. Esse setor ficou encarregado de propor novas reportagens, formular pesquisas, apresentar indagações e novas angulações, agendar entrevistas, sempre com o intuito de criar um noticiário atraente ao público (ERBOLATO, 1991). Com o passar dos anos, meios televisivos e redações integradas passaram a utilizar produtores, que recebem menos atribuições em relação às citadas acima e passam a funcionar mais como pauteiros. Além deles, todos os membros da redação podem sugerir pautas, como diagramadores, programadores, repórteres fotográficos, entre outros

As sugestões de pauta são provenientes não só de membros da redação. Fontes também costumam sugerir matérias às redações. Mais do que isso, a participação mais ativa da audiência é a grande novidade (capítulo III). As pessoas ligam para a redação, deixam comentários nas páginas, mandam mensagens por comunicadores, produzem textos em mídias sociais e compartilham conteúdo com os profissionais da redação.

Erbolato (1991) esclarece não ser difícil preencher diariamente as páginas dos jornais. Ele cita o funcionamento ininterrupto de uma tecnologia da época, o telex, para a transmissão e a captação das informações. Atualmente, o processo ganhou mais velocidade através de e-mails e mensagem instantânea, por exemplo. O material que chega às redações, através das assessorias de imprensa seria o bastante para fechar a edição inteira de um jornal, mas o deixaria menos atraente aos leitores. Pinto (2009) alerta que se deve olhar para os 
press-releases produzidos pelas assessorias sempre com desconfiança. A proposta dele é usálas como fonte, não como pauta em si.

\subsection{ENFOQUE E VALOR-NOTÍCIA}

O importante ao desenvolver a pauta, proveniente de um release ou não, é pensar na angulação do tema. Angular um tema em uma pauta é escolher o enfoque, indicar pontos de um assunto para abordar. De forma hipotética e ilustrativa, usamos como exemplo um release divulgado pelo Ministério do Meio Ambiente (MMA) sobre o desmatamento na Amazônia Legal. Ao ler o texto, quem desenvolve a pauta percebe que a região que possui a maior área desmatada, equivalente a mais de $80 \%$ dos dados, é uma terra com demarcação indígena. Por experiência e conhecimento pessoal, o repórter sabe que a etnia que ocupa a região tradicionalmente derruba árvores como ritual de renascimento e como oferenda à Mãe Terra. Como informação circula do MMA para imprensa, ter uma angulação diferente da divulgada garante, pelo menos em tese, uma nova perspectiva à informação na pauta.

O pauteiro, ou qualquer outro profissional que vai trabalhar na pauta, poderá buscar, a partir dessa percepção, apurar, por exemplo, se a tradição contribui para o desmatamento, resgatando quais espécies de árvores existem na região e como isso evoluiu durante os anos, se há plantação de outras árvores subjacentes, qual a relação dos índios com o desmatamento e como o estado se posiciona em relação à tradição. São perguntas que poderiam ser feitas para traçar caminhos e alcançar possíveis respostas.

As respostas às perguntas feitas no parágrafo anterior chegarão com a apuração a partir de diferentes fontes, que contribuirão para o desenvolvimento do enfoque ou apresentarão novas possibilidades de abordagem. Esse trabalho não possui exatamente uma ordem. É importante explicitar que uma série de forças atua e entra em jogo para defender suas posições. No caso hipotético, Funai, Ibama, índios e pesquisadores de diversas áreas, como antropólogos e cientistas sociais, são possíveis fontes. Personagens também compõem essa narrativa e trazem um novo olhar ao conteúdo. Todos eles apresentarão visões que podem ser parecidas ou distintas. Cabe ao repórter levantar todas essas posições e buscar pluralidade de opiniões para a construção do conteúdo.

Essa apuração e escolha de fontes acontecerá durante todo o processo de produção, considerado por muitos autores (ALSINA, 2003, WOLF, 1998) como a primeira etapa da 
rotina jornalística. Isso não quer dizer que em outras etapas, como na edição, o repórter não seja demandado a complementar informações, retornando mais uma vez ao ponto inicial da pauta. Isso acaba reforçando nossa ideia de reticularidade da pauta, bem como de elemento central do processo de produção.

Outro aspecto a se destacar na angulação está nas escolhas relacionadas à etapa de edição: escrita de título, sutiãs (antetítulo ou linha de apoio), legendas, formato de lide, músicas que irão compor a narrativa, tipo de imagens que serão usadas e áudios que poderão ser inseridos são elementos que integram o ângulo do conteúdo produzido e que podem ser previstos na pauta. Por exemplo, uma canção sugerida para ilustrar uma matéria jornalística com determinada temática pode alterar a percepção da audiência em relação ao conteúdo.

Neste aspecto, os valores-notícia também são utilizados para fazer escolhas. A noticiabilidade de um fato são fatores éticos e circunstâncias históricas, políticas, econômicas e sociais que viabilizarão a transformação do fato em informação jornalística. Integram a noticiabilidade elementos como as características do fato, o julgamento do jornalista, a cultura profissional, as condições da empresa, a disponibilidade do material e a relação com as fontes e com o público. Wolf (2001) assim define noticiabilidade (newsworthiness):

A noticiabilidade é constituída pelo conjunto de requisitos que se exigem dos acontecimentos - do ponto de vista da estrutura do trabalho nos órgãos de informação e do ponto de vista do profissionalismo dos jornalistas - para adquirirem a existência pública de notícias. (WOLF, 2001, p. 83)

Aliadas aos pontos citados no parágrafo anterior, colocamos o ineditismo, improbabilidade, utilidade, apelo, empatia, conflito, proeminência e oportunidade como características (PINTO, 2009) necessárias num fato para que ele se torne noticiável. Na maioria dos casos, a pauta possuirá nomes e fontes para a cobertura, informações básicas sobre o assunto, angulações, possíveis hipóteses, perguntas às quais deverá responder, memória do fato e de informações correlatas, telefones, contatos, sugestão de quem pode escrever a matéria e deadlines (JORGE, 2010).

Também a perspectiva-da-notícia (newsperspective) (ALTHEIDE, 1976) está atrelada ao conceito de noticiabilidade. Ela é a resposta que o veículo de comunicação dá a um dos pontos da atividade de escolha dos fatos em detrimento de outros: quais informações diárias são importantes? Para essa corrente de pensamento, transformam-se em produto jornalístico informações que são validadas pela cultura profissional dos jornalistas e são capazes de ser trabalhadas pelo órgão de imprensa sem provocar distorções à ordem estabelecida na ciclo produtivo cotidiano. É importante destacar que, em caso de 
acontecimentos excepcionais, como o incêndio na Boate $\mathrm{Kiss}^{40}$ ou o acidente aéreo que matou o presidenciável Eduardo Campos e seus assessores ${ }^{41}$, o meio de comunicação tem a flexibilidade necessária para adaptar os seus procedimentos à contingência da situação.

\subsection{ESTRUTURA E EXISTÊNCIA DA PAUTA}

Para que a pauta seja executada, segundo Henn (1996), é necessário existir consenso entre os profissionais, como também organização hierarquizada, estando os editores à frente desse procedimento. Apesar disso, não é possível falar que existe um modelo universal de pauta. Nos diferentes meios de comunicação, as pautas terão formatos variados, adotando linguagens particulares de cada um deles. Em termos estruturais, elas são divididas em dois aspectos: culturais, por estarem relacionadas à cultura da redação e da profissão, e de suporte, por estarem ligadas ao veículo que a produz.

A perspectiva cultural é comum a todos os meios e está imbricada no jornalismo, independentemente do suporte em que a informação é produzida. Sugestões de fontes, resgate de memória, possíveis angulações e gênero utilizado são inerentes ao jornalismo. Nesses aspectos, diversos campos estarão influenciando a produção.

As pautas relacionadas ao suporte, de veículo, ligam-se aos equipamentos utilizados, aos formatos que serão usados para a construção da narrativa e à arquitetura da informação. Esse aspecto estará mais vinculado aos produtos jornalísticos digitais. Para o nosso trabalho, conhecer e mapear essas perspectivas é essencial. Defendemos que essas concepções influenciarão os aspectos culturais e a exploração do potencial do suporte sempre dependerá das competências da recepção, ou seja, da audiência.

A pauta usada no telejornalismo é parecida com a do dia-a-dia do jornal impresso, com a diferença de conter a preocupação de captar imagens, áudio e movimento (JORGE, 2010). Como geralmente trabalha mais de um profissional nas equipes de jornalismo da TV, há diversos aspectos que precisam ser levados em conta na hora da produção da pauta. Geralmente o produtor, ou quem elabora a pauta, precisa marcar as entrevistas e saber em

\footnotetext{
${ }^{40} \mathrm{O}$ incêndio na boate Kiss, ocorrido na madrugada de 27 de janeiro de 2013, foi uma tragédia que matou 242 pessoas e feriu 680 outras numa casa de shows da cidade de Santa Maria, no Rio Grande do Sul.

${ }^{41} \mathrm{O}$ ex-candidato do PSB à Presidência da República, Eduardo Campos, morreu em 13 de agosto de 2014 em um acidente aéreo em Santos (SP). O jato em que estava o político caiu em Santos, São Paulo.
} 
quais ambientes as imagens e os áudios serão gerados. Isso garante que a captação do som e das imagens não sofra interferência.

Nos suportes mais instantâneos, como no webjornalismo, "o fluxo contínuo e acelerado de notícias está provocando o desaparecimento da pauta como a etapa formal que inicia todo o processo jornalístico" (LUZ, 2005b, p. 97). O que suspeitamos é que a autora se refere mais especificamente à reunião de pauta ou mesmo à pauta como elemento organizativo. Nesse caso os editores acompanham via contatos telefônicos e via sistema de publicação de conteúdo a produção do repórter.

O que está desaparecendo, na verdade, é a reunião de pauta no âmbito da redação, principalmente para o hard news ${ }^{42}$. A pauta passa a nascer do dia-a-dia e vai sendo trabalhada à medida que o fato vai se desenvolvendo. Os jornalistas viram "escravos" dos acontecimentos e começam a ser mais tensionados pela concorrência. "A descrição mais reiterada da pauta digital é que o editor online ou coordenador se reúne várias vezes ao dia com cada jornalista” (GREENE-GONZÁLEZ, LECAROS-MENÉNDEZ, 2015, p. 604 ) ${ }^{43}$.

Essas circunstâncias estão mais relacionadas aos temas factuais, sendo que esse tipo de efeito está acontecendo em todos os suportes que possuem maior agilidade, como o rádio. Isso não quer dizer que a pauta tenha desaparecido nesses suportes. Escolher formatos midiáticos, definir as lexias ${ }^{44}$ das reportagens, sugerir tipos de ilustração, infográficos, imagens 360 graus e games são algumas das possibilidades deliberadas nesses suportes digitais.

Para Jorge (2010, p. 52), a pauta de internet é um roteiro direto e objetivo. Ordena, mais do que sugere, alinha, mais do que motiva, e obriga, mais do que solicita, aos redatores dos sites o cumprimento de ações para chegar às matérias. Contudo, essa ordem nem sempre funcionará em todos os meios da internet e para todos os formatos. As matérias mais trabalhadas, as long form $^{45}$, por exemplo, exigem um planejamento e detalhamento maior.

Schwingel (2012, p. 51) explica que, independente de qualquer técnica e tecnologia utilizada, "o mais importante é a composição dos conteúdos em termos de hipertextualidade e dos recursos multimidiáticos, além da estruturação de uma narrativa interativa multimídia com níveis de informação e desdobramentos contextuais": "De maneira geral podemos

\footnotetext{
${ }^{42}$ Segundo a Folha (2001), hard news "é o relato objetivo de fatos relevantes para a vida política, econômica e cotidiana $[\ldots] "$ ".

43 "La descripción más reiterada de la pauta digital es que el editor online o coordinador se reúne varias veces al día con cada periodista

${ }^{44} \mathrm{O}$ termo é criado pelo lingüista francês Bernard Pottier e é usado para representar qualquer unidade lexemática, sendo sua menor unidade a palavra. No hipertexto, a palavra é utilizada para se referir a páginas ligadas por links, que formam o hipertexto.

${ }^{45}$ São narrativas longas com formato multimídia.
} 
desenvolver a sugestão de pauta como roteiro para narrativas interativas multimídia, estruturando-a no papel mediante a integração da arquitetura da informação" (SCHWINGEL, 2012, p. 47).

\subsection{REUNIÕES DE PAUTA}

Apresentados os elementos culturais e de veículo (suporte), passamos para um dos pontos cruciais da rotina produtiva nas redações: as reuniões de pauta. Este momento proporcionará um olhar mais abrangente aos temas propostos. A reunião de pauta é, na verdade, uma das etapas na seleção de conteúdos pelos veículos. No sentido da teoria do gatekeeping, representa um novo portão (gate) que a informação precisará cruzar para ser publicada, depois de ter sido apontada pelo repórter, passado pelo crivo do editor e materializada em forma de sugestão de pauta. Cada meio de comunicação estipulará os horários, os profissionais que participarão e as formas como acontecerão esses importantes encontros na rotina diária das redações, as reuniões de pauta. Neste trabalho, classificamos as reuniões de pauta em a) integrada; b) de meio e c) por editoria.

a) As reuniões integradas, feitas com editores de mais de uma plataforma, quer pertençam, quer não a um mesmo grupo de comunicação, servem para o planejamento de coberturas ou das edições diárias, possibilitando que os conteúdos sejam harmônicos e que esforços sejam poupados. Geralmente acontecem três vezes ao dia nos que possuem redação convergente: no começo do dia, para listar os fatos que serão cobertos e avaliar as edições dos dias anteriores; no meio do expediente, para acompanhar o desenvolvimento dos assuntos do dia e cobertura dos meios; e no fechamento, para elencar matérias que serão destaque nos impressos e nos jornais que são vespertinos ou noturnos. São encontros circulares porque enviam e recebem informações. É uma tradição que tem nascedouro nos jornais impressos e que agora faz parte também dos jornais on-line como alternativa de organização das informações diárias.

b) As reuniões de meio agruparão os editores das seções para combinar, planejar ou fechar a edição. Antes, em cada editoria (como veremos a seguir), são mostradas sugestões de fatos que se transformarão em matérias ao longo do dia. Dependendo dos assuntos e periodicidade da edição, algumas pautas poderão ser publicadas imediatamente nas plataformas on-line ou serão trabalhadas por mais tempo para edições especiais. Em todos os 
tipos de reunião de pauta podem ser apresentados a angulação (enfoque) da matéria e os possíveis destaques para cada suporte, sendo este momento o primeiro filtro editorial do meio. Neste ponto do trabalho dos jornalistas, é possível que as matérias sugeridas pelos repórteres saiam já com uma angulação ou ganhem uma nova. Quando os desdobramentos da pauta estão menos desenvolvidos, ou quando a pauta ainda é uma ideia, o repórter precisa ampliar as informações e mergulhar mais no processo de apuração a fim de trazer fatos concretos que justifiquem o interesse pelo assunto. É a partir daí que o editor leva sua lista de matérias para a reunião de editores ou passa para o editor geral a listagem de matérias que será objeto da reunião integrada.

O formato organizacional da empresa vai diferenciar esses dois tipos de reunião de pauta (a e b). A integrada, como o nome já diz, busca utilizar a mão de obra dos jornalistas e as tecnologias dos diferentes suportes unificando as redações em um único espaço. É uma junção de forças para a produção. Muitas das mudanças que ocorrem hoje nas rotinas produtivas são resultantes do enxugamento das redações gerando, consequentemente, acúmulo de trabalho para os profissionais envolvidos. Como mudam os formatos produzidos para a circulação da informação, pode acontecer que diferentes angulações e tipos de fontes sejam usadas para cada plataforma, como alternativa para diferenciar a cobertura, e isso muda a pauta.

Enfim, a reunião de pauta de veículo continua sendo a tradicional reunião de pauta com os editores de um só meio. Todos os editores se reúnem em volta de uma mesa, sob a coordenação do editor-chefe ou editor-executivo, para debater os assuntos que serão abordados na edição do dia. Aqui também é um momento de aprofundamento e problematização dos temas que serão trabalhados.

c) A terceira espécie de reunião de pauta, que classificamos como reunião de editoria, é realizada com a equipe que trabalha numa determinada temática, e que historicamente são os jornalistas ${ }^{46}$. Participam do encontro repórteres e editores. Aqui os repórteres (que assumem também a função de pauteiros de si e dos colegas, já que sugerem matérias para outros fazerem), bem como os editores, apresentam pautas com ideias de conteúdo a ser desenvolvido. A reunião de editoria possui periodicidade e formato diferente em cada redação, bem como em cada editoria, variando de acordo com os editores. Há possibilidade de pautas serem indicadas de forma verbal e escrita. "Em todas as reuniões de

\footnotetext{
${ }^{46}$ Com o desenvolvimento da sociedade e o crescimento dos centros urbanos, novas demandas de consumo de informação surgiram e com elas editorias foram criadas para atender essas necessidades. A partir disso, jornalistas passaram a se especializar em temáticas.
} 
pauta, os participantes são instados a falar e devem contribuir com novos assuntos, com novas visões pessoais, com informações enriquecedoras. Apesar de, no geral, quem sugere um assunto ser o indicado para realizar a matéria" (JORGE, 2010, p. 42).

Os editores, titulares de cada editoria, repassam o cronograma de sua editoria aos outros durante a reunião integrada ou reunião do veículo, destacam as pautas mais importantes e às vezes pede destaque no jornal e/ou mais espaço para uma matéria (ERICSON, BARANEK, CHAN, 1987). Ao apresentar o cronograma das editorias, todos os presentes colaboram com a construção e debate dos assuntos que serão cobertos, para finalmente conformar uma prévia da pauta. Quando isso acontece, o documento fica disponível, on-line ou não, para os editores acompanharem sua evolução, seus desdobramentos. É importante frisar que cada editor deve apresentar a composição de todos os conteúdos sob sua responsabilidade, não somente das reportagens especiais.

Ao final desse encontro, as propostas ainda podem sofrer alterações tanto do editor geral, como também durante o fechamento da edição pelo editor do caderno ou seção. Os motivos para a mudança são os mais diversos, e podem acontecer, por exemplo, a partir de um dado apurado de forma errônea ou de um novo acontecimento que surja e faça com que a proposta anterior perca força para ser publicada. A depender da importância do conteúdo, essa modificação será comunicada ao editor geral, sendo então substituída por outra matéria. Essas transformações vão compor a edição final e garantir o equilíbrio dos conteúdos abordados.

Nesse processo, o editor geral seria o gatekeeper principal, já que ele daria a palavra final sobre os conteúdos que circularão na edição. Esta afirmação é confirmada pelos estudos de Puente et al. (2014), que concluem que a inserção das tecnologias nas redações e as novas estratégias adotadas estão reforçando a figura do editor como o principal selecionador, sendo assim uma figura central na hora de decidir as pautas. "A importância do editor na pauta e o que ela contém fica clara nas entrevistas: sugere focos, entrevistados, faz mudanças ao longo do dia e determina se algo vai ser reportado e o quê. Define quais temas incluir e quais excluir” (GREENE-GONZÁLEZ, LECAROS-MENÉNDEZ, 2015, p. 21$)^{47}$.

É possível que, nesse debate, novos aspectos sejam pensados, sugeridos e, com isso, outros elementos sejam acrescentados à cobertura de algum assunto. Antecedentes históricos, angulações já feitas pela concorrência e diferenças com relação à pretendida pela pauta, perguntas a que o conteúdo pretende responder, tipos e quais fontes serão usadas, formatos

\footnotetext{
${ }^{47} \mathrm{La}$ importancia del editor en la pauta y lo que incluye queda clara en las entrevistas: sugiere focos, entrevistados, hace cambios a lo largo del día y determina si se reportea y qué. Define qué temas incluir y cuáles excluir
} 
que serão usados, possível arquitetura da informação são alguns dos elementos necessários para a apresentação de uma ideia. Isso varia a depender do suporte e da redação em que ela será apresentada.

Em algumas redações, como no extinto O Globo A Mais, muitas dessas reuniões eram feitas on-line, através de comunicadores digitais de serviços públicos, como o do Google, ou por comunicadores da própria empresa (MARQUES, 2015). As reuniões deixavam de ser únicas para ser descentralizadas, acontecendo de forma ininterrupta. Nesse caso, os contatos com os repórteres, que podem tanto partir deles como do editor, são feitos por telefone ou por rádio comunicador. "A presença do editor é mais contínua e permanente graças a estas tecnologias do que era antes, quando o jornalista deveria resolver sozinho as tomadas de decisões sobre o problema" (GREENE-GONZÁLEZ, LECAROS-MENÉNDEZ, 2015, p. 8).

\subsubsection{Cruzamento de culturas profissionais: da pauta à circulação}

Por muitos anos, somente jornalistas participavam da reunião de pauta nos jornais. $\mathrm{O}$ desenvolvimento de tecnologias digitais, a criação de novas narrativas jornalísticas e a adoção de novas estratégias empresariais, como a convergência das redações e a apropriação da internet para produção jornalística, profissionais pertencentes a outros campos passaram a atuar também nessas reuniões.

Em trabalho anterior (MARQUES, 2015, p. 227), citamos o caso das reuniões do aplicativo para tablets o $O$ Globo A Mais, nas quais designers debatiam as pautas e tinham até poder de veto: "Há nesse sentido uma redefinição da função dos diagramadores, que passam a participar de forma ativa nas etapas de produção e ganham novas responsabilidades e competências no jornalismo".

Estudos clássicos, como o de Breed (1955), indicavam que o controle social na produção e publicação de conteúdos nas redações envolvia negociações apenas entre os staffers - repórteres, redatores e revisores - e os executivos - jornalistas no cargo de editor e os proprietários das empresas jornalísticas. O trabalho de Breed (1955) estudou as redações tradicionais, com estrutura verticalizada, nas quais há uma intensa negociação entre os jornalistas para decidir os assuntos que serão abordados e produzidos. Outros estudos seminais (GANS, 1979; TUCHMAN, 1978), ancorados na teoria do newsmaking, continuam 
apontando para o papel central do jornalista no processo de produção, edição e circulação dos conteúdos.

Hoje percebemos que a introdução de novos atores nessas instâncias de deliberação indica que transformações estão acontecendo nas rotinas de produção jornalística. Contudo, é preciso ressaltar que, dentro das redações, há tensões entre os agentes - profissionais que fazem parte de diferentes campos e atuam no mesmo espaço. Assim aconteceu e acontece com os jornalistas e os diagramadores que negociavam a publicação dos textos, bem como tem acontecido com os profissionais que trabalham nas versões para dispositivos móveis. Jornalistas têm estabelecido novas negociações com agentes diferentes, denominados “tecnoatores" (CANAVILHAS et al, 2014; CANAVILHAS et al, 2016):

\begin{abstract}
A atual presença de tecnoatores nas redações apresenta potencial para alterar esta estrutura básica. Desde um ponto de vista instrumental, são eles que possuem profundo domínio técnico sobre linguagens de programação e softwares de edição que agem sobre o trabalho jornalístico, influenciando simultaneamente os procedimentos e os produtos. Designers e programadores conquistam proeminência diante da carência ou completa falta de expertise dos jornalistas em um momento de acelerada mudança nas tecnologias. E não se trata de uma questão meramente instrumental, pois poderemos estar perante um intenso choque entre culturas profissionais. (CANAVILHAS et al, 2016).
\end{abstract}

Em todas as instâncias de produção, é possível encontrar novos profissionais atuando. Há casos, como no El País, em que bibliotecários foram contratados para criar etiquetas de classificação de conteúdos produzidos pelos jornalistas. Algo semelhante à atuação de técnicos que trabalham com estratégias de Otimização de Motores de busca no jornal $\mathrm{O}$ Estado de $\mathrm{S}$. Paulo. Esses novos profissionais incorporados às rotinas produtivas das redações participam das reuniões de pauta com o objetivo de agregar e enriquecer o conteúdo a ser disponibilizado aos leitores.

\title{
4.5 PAUTA NA CONTEMPORANEIDADE
}

Quanto à forma, as pautas podem ser compreendidas, nas redações atuais, sob duas perspectivas: a primeira está relacionada a uma listagem de temas que serão tratados em uma edição de uma plataforma e a segunda, a um produto ou gênero jornalístico. Com isso, a pauta cumpre duas funções principais (LAGE, 2001): uma função macro, organizando toda a 
edição, e uma função micro, organizando somente um assunto que será tratado na edição. Neste trabalho, nomeamos, respectivamente, pauta da edição (macro) e pauta de conteúdo (micro).

A pauta de edição e a pauta de conteúdo têm caráter organizativo. A primeira é desenvolvida e controlada por editores e dá uma visão geral dos temas que serão tratados na edição. A segunda é feita por qualquer membro da redação e é referente a somente um assunto tratado. Com a constante alteração dos modelos de negócio e mudanças nas estratégias comerciais, como apresentamos no capítulo III, existem diferentes tipos de organização das redações e formas de desenvolver o trabalho jornalístico. Com isso, propomos que, para fins operacionais (Gráfico 8), a pauta de edição ou Pauta Macro seja dividida em convergente, geral e por editoria. O que chamamos Pauta Micro se refere a um único conteúdo.
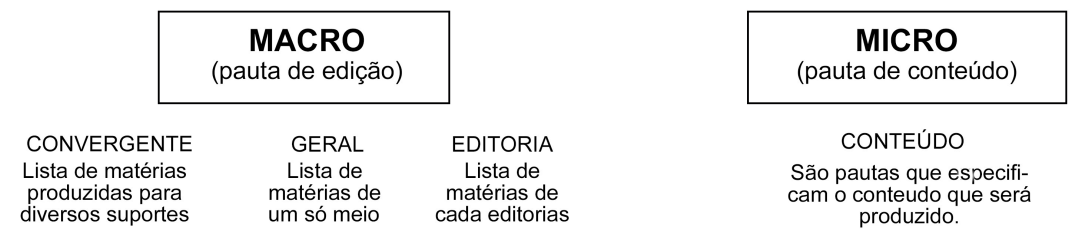

GRÁFICO 8: Tipos de pautas e suas divisões (produção nossa).

A pauta convergente estará presente em caso de grupos de comunicação que possuem redação integrada em seus quatro âmbitos (empresarial, profissional, editorial e tecnológico). Esse tipo de pauta organiza quais repórteres cobrirão determinada temática e como os arquivos serão adaptados a cada suporte ou replicados para cada plataforma (rádio, impresso, televisão, web, tablets ou telefones móveis), bem como quais equipamentos serão utilizados para produção do material.

Jornalistas que atuam nesse tipo de redação tendem a cumprir múltiplas tarefas e esta pauta, de natureza mais complexa, tem que gerenciar diferentes recursos humanos e técnicos, bem como espaços e horários em que os conteúdos serão publicados nos distintos meios. Algumas redações possuem software para controlar esses fluxos, como é o caso do Globo, e outros utilizam serviços da web para armazenamento e compartilhamento de informações, como Google Docs. Com isso, é gerada uma lista de temas que serão cobertos e comporão o conteúdo final de cada edição, informando inclusive o horário de publicação de cada suporte. 
Esta é a forma como o editor de convergência gerencia a cobertura dos meios envolvidos. As reuniões são controlados pelos editores gerais ou pelos convergentes, que também se encarregam de consolidar a pauta (MARQUES, 2015).

O que chamamos pauta geral - parte da Pauta Macro (de edição), em nossa categorização - está relacionada somente a uma plataforma e é resultado da consolidação de matérias jornalísticas de todas as editorias. A pauta geral consiste em uma listagem de assuntos que farão parte de uma edição. É muito parecida com a primeira (pauta convergente?), com a diferença de que é feita pensando somente num veículo, levando em consideração apenas as características de $u m$ suporte. Quem controla e desenvolve esse tipo de pauta é o editor geral. Qualquer alteração é comunicada pelos chefes das editorias e ela serve de balizadora do fechamento da edição. Matérias que ganharão destaque, e que são apostas do dia ${ }^{48}$, também são realçadas nesse tipo de pauta. Como exemplo podemos citar a pauta completa em uso pelo jornal Correio Brasiliense, que se constitui numa listagem diária dos temas que farão parte da próxima edição. Ela serve de controle principalmente para o editor geral e para o fechamento do periódico.

Ambas, tanto a primeira como a segunda, podem ser alteradas à medida que os repórteres vão fazendo suas coberturas, bem como no momento em que o editor vai editar o conteúdo para publicação, identificando, principalmente, problemas de apuração.

A chegada do espelho da edição, geralmente chega às $15 \mathrm{~h}$ em jornais diários, indicando os espaços que os jornalistas terão que dividir com a publicidade, pode mudar também a cobertura do impresso ou dos veículos que utilizam o padrão impresso, como o Zero Hora Noite. Há uma tencionamento forte tanto na redação como no setor comercial para ter mais espaço. Para uma boa rentabilidade, no Zero Hora, o ideial é que o jornal atinja 30\% das suas páginas impressas. Novos acontecimentos durante o dia tendem a alterar seu conteúdo também, por derrubarem matérias com menos força. Ao escolher qual assunto derrubar, os eventos factuais sempre terão maior força pelo sua perenidade. O que não é tão importante pode "morrer" também. Isso vai acontecer também com a pauta anterior (a convergente), que é susceptível a estes eventos.

O último modelo das Pautas Macros é a pauta de editoria. Elaborada pelo editor encarregado do tema, é a lista de matérias que farão parte de um dos cadernos, editoria ou seção, no caso dos impressos, mas também na web e em dispositivos móveis, ou a lista de quadros de um telejornal ou radiojornal. É por meio dela que o editor se reporta ao editor

\footnotetext{
${ }^{48}$ Apostas do dia são as matérias mais trabalhadas e que possivelmente ganharão capa do jornal.
} 
geral, sendo também a forma como este consegue ter uma visão global do conteúdo que será produzido.

A Pauta Micro, de conteúdo, trata somente de um assunto específico. Busca apresentar antecedentes do assunto, contextualizando inclusive o estado em que se encontra o tema e como os concorrentes o trataram. Essas pautas também explicam e direcionam qual angulação a matéria deve conter, indicam possíveis fontes e personagens, apresentam perguntas que se pretende responder, podem ter hipóteses a ser confirmadas ou refutadas, indicam qual repórter deve fazer a cobertura, quais formatos midiáticos deve abordar, quais são as exigências da cobertura e o deadline.

Os quatro modelos são complementares e podem ser consolidados no fechamento da edição. Estamos dizendo com isso que, apesar de ser raro, um grupo ou um meio de comunicação pode manter todos os modelos de pauta, dependendo do seu sistema organizacional de funcionamento. Todas essas subdivisões, de forma ascendente, provocam impacto uma na outra no momento em que são alteradas. É importante destacar também que os veículos web e alguns veículos móveis que trabalham em tempo real têm maior limitação organizativa e isso provoca uma aproximação maior do editor ao repórter, que passa a controlar suas publicações via sistema de publicação do site, portal ou aplicativo.

A diferença central entre elas, apenas para enfatizar o que já afirmamos, é que as pautas convergente, geral e de editoria - subdivisões da pauta de edição - estão mais relacionadas a uma listagem de fatos a serem cobertos pelo noticiário; e a pauta de conteúdo está focada na temática de um fato que receberá tratamento jornalístico. Elas são organizadas de acordo com uma hierarquia de importância de cada assunto, indicando o posicionamento dos conteúdos na edição - as que receberão mais destaque que as outras.

$\mathrm{Na}$ contemporaneidade a pauta continua sendo protagonista na organização das edições, desempenhando funções de:

1. planejamento de uma edição ou de parte da edição: listagem dos fatos a serem cobertos no noticiário e dos assuntos a serem abordados em reportagens;

2. controle interno: para manutenção da linha editorial. Aqui poderão entrar temáticas, ângulo de interesse e fontes utilizadas;

3. recursos internos: com indicações logísticas para execução da matéria e técnicas como equipamentos e profissionais envolvidos, contatos, e dimensão pretendida da matéria, demanda de recursos para execução do trabalho, equipamentos que serão usados e profissionais que estarão envolvidos; 
4. questões estruturais da narrativa: como arquitetura da informação e formatos de mídia sugeridos.

Ao trilhar a construção do produto jornalístico, o repórter passa a fazer escolhas a partir de julgamentos internalizados no habitus do seu campo (BOURDIEU, 1998). Mesmo que não seja intencional, a linha editorial, o público a que se destina o conteúdo, a capacidade coletiva de avaliar os temas que farão parte do conjunto do noticiário, e a capacidade individual de interpretar o tema, por parte de quem elabora o produto jornalístico, vão influenciar esse trabalho. Fica claro para nós que os cinco níveis que Shoemaker e Vos (2011) propõem, expostos no capítulo II, estão implicados nesse processo.

Como estamos utilizando o gatekeeping como uma das teorias que dão sustentação ao nosso trabalho, empregamos os cinco níveis para o estudo do gatekeeping em contextos contemporâneos proposto por Shoemaker e Vos (2011) para observarmos o desenvolvimento de pauta: o dos profissionais da comunicação individuais, por exemplo, suas atitudes políticas; o das rotinas ou práticas do trabalho em comunicação, como a pirâmide invertida; o nível organizacional, como a análise de variáveis como parâmetros de participação de propriedade na mídia; o nível de análise socioinstitucional, que inclui influencias do governo e grupos de interesse; e o nível do sistema social, que estão a analise de variáveis como ideologia e cultura (SHOEMAKER e MAYFIELD, 1987; SHOEMAKER e REESE, 1996). Acreditamos que esses pontos nos auxiliarão na observação participante, quando lançaremos um olhar à construção da pauta e a todo o seu desenvolvimento.

No próximo capítulo apresentaremos os resultados da nossa observação participante nas redações do $O$ Globo A Mais, Diário do Nordeste Plus e Zero Hora Noite. 


\section{CAPÍTULO V}

\section{PERCURSO METODOLÓGICO}

Este tópico delimitará e descreverá os procedimentos e caminhos adotados por este trabalho. Para identificar e refletir sobre a construção da pauta em edições para tablets, num contexto de convergência dos meios, é necessário utilizar uma metodologia que abarque as diversas nuances que envolvem o processo de construção da notícia. Como expomos no tópico 2.1, esta pesquisa está filiada à corrente de estudo "estruturalista construtivista" (structuralist constructivism) ou "estruturalismo genético" de Pierre Bourdieu (1998). Com isso, estamos dizendo que, ao fazer nossa análise, levamos em conta a existência de estruturas objetivas, que são independentes da consciência e da vontade dos agentes.

Também temos claro que essas estruturas são produto de uma gênese social dos esquemas de percepção, de pensamento e de ação e que os arcabouços, as representações e as práticas que as constituem são constituídas continuamente (BOURDIEU, 1999). O ponto central do método é que as ideias são tributárias da sua condição de produção. Trata-se de uma pesquisa no âmbito do jornalismo digital que utilizará métodos de pesquisa quantitativa e qualitativa de forma complementar (MACHADO, PALACIOS, 2010). O trabalho está em harmonia com as investigações desenvolvidas na Linha de Pesquisa Jornalismo e Sociedade do Programa de Pós-Graduação em Comunicação da Universidade de Brasília (UnB).

Em conformidade com o pensamento exposto, consideramos como apropriada para o nosso trabalho o sistema de pesquisa desenvolvida e adotada pelo Grupo de Pesquisa em Jornalismo Online (GJOL) da Universidade Federal da Bahia (UFBA). De acordo com Machado e Palacios (2010), trata-se de uma "metodologia híbrida", marcada pela discussão conceitual, complementada pela incorporação de estudo de casos de organizações relacionadas ao objeto da pesquisa, possibilitando, assim, que a produção conceitual seja testada.

O método adotado pelo GJOL é marcado pela combinação de metodologias aplicadas a estudos de casos múltiplos (YIN, 2005), com o objetivo de ampliar a descrição, a explicação e a compreensão do objeto. Um estudo de caso é uma pesquisa empírica que investiga um fenômeno dentro do seu contexto de vida real, especialmente quando os limites entre o fenômeno e o contexto não estão claramente definidos (YIN, 2005, p32). Yin (2005) 
diz que o estudo de caso é adequado quando os pesquisadores colocam questões do tipo "como" e "por que", quando o pesquisador tem pouco controle sobre os acontecimentos e/ou quando o foco se encontra em fenômenos contemporâneos inseridos em algum contexto da vida real. Como afirma Yin (2005), um estudo de caso possui pelo menos duas fontes de evidência: a observação direta dos acontecimentos que estão sendo estudados e as entrevistas com as pessoas envolvidas.

Cinco principais instrumentos metodológicos foram utilizados para a realização da pesquisa: 1) revisão da literatura; 2) observação preliminar exploratória dos versões para tablets; 3) aplicação de formulários de observação; 4) realização de entrevistas; 5) e observação direta na meios.

Inicialmente percorremos uma das etapas aconselhadas pelo método proposto pelo GJOL: revisão bibliográfica e a exploração das organizações relacionadas ao objeto de estudo. A primeira dessas etapas aconselhadas pela metodologia nos auxiliou na exploração inicial do objeto e durante toda a pesquisa. Sendo assim, a revisão bibliográfica foi o primeiro passo desta pesquisa. Esse primeiro momento, que seguiu até a conclusão do trabalho, buscou identificar, localizar e obter bibliografia pertinente ao assunto estudado.

Num sentido restrito, [revisão bibliográfica] é um conjunto de procedimentos que visa identificar informações bibliográficas, selecionar documentos pertinentes ao tema estudado e proceder à respectiva anotação, fichamento das referências ou dados dos documentos para que sejam posteriormente utilizados na elaboração de um trabalho acadêmico (STUMPF, 2011, p 51). Todos os trabalhos lidos foram fichados para garantir a exatidão das referências bibliográficas. Conhecer a literatura existente sobre o assunto aproblema específico.

O segundo momento foi a exploração inicial do fenômeno. Isso nos permitiu ter uma visão sobre o tema, especialmente por ele ainda ser pouco explorado. Para isso, mapeamos quais meios de comunicação jornalísticos possuíam versão para tablet. Para não fazer uma busca sem critérios, escolhemos identificar as empresas que eram sócias da Associação Nacional de Jornais (ANJ). Ao total, em junho de 2013, eram 141 associados. Chegamos a fazer uma ligação telefônica para a ANJ, com o intuito de saber se eles tinham esse levantamento de quais empresas possuíam versão para tablet. Identificado que não existiam as informações na Associação, passamos a visitar as páginas da internet dos associados buscando descobrir quais possuíam versões.

A procura foi realizada nos sites e portais dos jornais de forma visual e utilizando as palavras-chave na busca: tablet, ipad e móvel. Essas palavras foram escolhidas a partir de uma 
observação inicial para a identificação das mais usadas. Além disso, de forma complementar, fomos na loja da Apple e utilizamos o nome meio de comunicação para encontrar o aplicativo. Os resultados desta busca são apresentados na capítulo III.

De posse dos dados sobre os veículos brasileiros que possuem versões para tablets, passamos a fazer uma observação do conteúdo e classificar os aplicativos. É através de uma leitura flutuante do conteúdo encontrado que se desenvolve uma visão mais geral sobre o tema, de cunho aproximativo, considerando que "muitas vezes as pesquisas exploratórias constituem a primeira etapa de uma investigação mais ampla" (GIL, 2010, p. 27). Com o intuito de atualizar esses dados sobre desenvolvimento de aplicativos para tablets e verificar as pistas dadas pelas informações do mercado, que indicavam uma redução nas vendas desses dispositivos móveis (referência) e uma possível diminuição do investimento em aplicativos jornalísticos, voltamos a fazer a pesquisa no período de 09 a 17 de dezembro de 2016.

\begin{tabular}{|c|c|c|c|}
\hline Cargo & Meio de comunicação & Ano & apêndice \\
\hline Repórter 1 & O Globo A Mais & 2014 & $\mathrm{D}$ \\
\hline Repórter 2 & O Globo A Mais & 2014 & $\mathrm{E}$ \\
\hline Repórter 3 & O Globo A Mais & 2014 & $\mathrm{~F}$ \\
\hline Repórter 4 & O Globo A Mais & 2014 & $\mathrm{G}$ \\
\hline Repórter 5 & O Globo A Mais & 2014 & $\mathrm{H}$ \\
\hline Repórter 6 & O Globo A Mais & 2014 & $\mathrm{I}$ \\
\hline Editor 1 & O Globo A Mais & 2014 & $\mathrm{~J}$ \\
\hline Editor 2 & O Globo A Mais & 2014 & $\mathrm{~K}$ \\
\hline Editor 3 & O Globo A Mais & 2014 & $\mathrm{~L}$ \\
\hline Editor 1 & Zero Hora & 2016 & $\mathrm{M}$ \\
\hline Produtor 1 & Zero Hora & 2016 & $\mathrm{~N}$ \\
\hline Produtor 2 & Zero Hora & 2016 & $\mathrm{O}$ \\
\hline Repórter 1 & Zero Hora Plus & 2016 & $\mathrm{P}$ \\
\hline Editor 1 & Zero Hora Plus & 2016 & Q \\
\hline Programador & Zero Hora & 2016 & $\mathrm{R}$ \\
\hline Editor-geral & Diário do Nordeste & 2016 & $\mathrm{~S}$ \\
\hline Diretora executiva digital & Diário do Nordeste & 2016 & $\mathrm{~T}$ \\
\hline Editor Executivo & Diário do Nordeste & 2016 & $\mathrm{U}$ \\
\hline Editor & Diário do Nordeste Plus & 2016 & $\mathrm{~V}$ \\
\hline Repórter 1 & Diário do Nordeste Plus & 2016 & $\mathrm{~W}$ \\
\hline Repórter 2 & Diário do Nordeste Plus & 2015 & $\mathrm{X}$ \\
\hline Repórter 3 & Diário do Nordeste Plus & 2015 & $\mathrm{Y}$ \\
\hline Editor-assistente & Diário do Nordeste & & Z \\
\hline
\end{tabular}

TABELA 3 - entrevistas feitas nas redações que fazem parte do corpus (produção nossa).

Na redação de $O$ Globo $A$ Mais, edição vespertina das organizações Globo, buscamos, entre os dias 16 e 18 de outubro de 2014, identificar as rotinas e estratégias utilizadas pelos profissionais envolvidos no processo de construção e desenvolvimento das edições exclusivas para tablets . Como metodologia de trabalho, adotamos a observação artificial (GIL, 2010) . Acompanhamos o fechamento de edições do vespertino. Além disso, 
para obtenção de mais dados, fizemos entrevistas estruturadas e semiestruturadas com todos os jornalistas da redação, o que incluiu seis repórteres (APENDICES D, E, F, G H, I), um editor, um editor-adjunto, e uma subeditora do periódico (APENDICES J, K, L) ${ }^{49}$. Diante da ausência de análises sobre rotinas de produção para esse suporte, a visita nos permitiu delinear e conhecer melhor o estado da arte das rotinas de produção das versões para tablets e possibilitou a construção e a delimitação mais clara de nossa pesquisa.

Para isso, relacionamos o fluxo de produção do periódico com as três fases propostas por Wolf (2003) e Alsina (2009): i) coleta, ii) seleção, e iii) edição/apresentação/circulação. Apesar de termos escolhido a divisão em três fases, vimos que o processo informativo pode ser composto por outras fases que variam segundo a organização do trabalho de cada redação e de cada meio de comunicação (ADGHIRNI, 2012).

Segundo Machado e Palacios ( 2010, p. 204), “os critérios básicos para a definição dos objetos do estudo de casos são: 1) originalidade; 2) representatividade e 3) diversidade". Selecionamos então O Globo, Diário do Nordeste Plus e Zero Hora Noite, depois de definir as hipóteses, que seriam: (1) a inserção das versões para tablets nas redações proporciona transformações na produção da pauta, com repercussão nos processos de produção, edição e distribuição dos conteúdos; (2) A integração das redações transformam a pauta em um organismo vivo, em que seu conteúdo vai sendo adequado de acordo com as necessidades de cada suporte.

As observações no jornal Zero Hora foram feitas durante os dias 3 a 7 de outubro de 2016, durante os dois turnos de trabalho. Foi possível acompanhar o desenvolvimento da pauta, ou seja, da produção até a circulação de cinco edições. Entrevistas semiestruturadas foram realizadas também.

Em 2015 chegamos a fazer uma visita exploratória ao Diário do Nordeste Plus. Com isso, acompanhamos um dia de produção e fizemos algumas entrevistas estruturadas com os membros da redação. Em 2016, a observação aconteceu durante a semana de 10 a 12 de outubro de 2016, ou seja, só podemos acompanhar dois dias de produção. Não foi permitido participar das reuniões de pautas gerais, somente a do Diário do Nordeste Plus, que é feita uma vez por semana.

$\mathrm{Na}$ segunda visita foram feitas entrevistas semiestruturadas com repórteres e editores do jornal. A intenção da entrevista, como afirma Duarte (2011), é explorar os assuntos, aprofundar-se mais, descrever os processos, compreender o passado, apontar perspectivas, e, a

\footnotetext{
${ }^{49}$ No tópico 4.1 apresentamos os resultados da visita ao Globo a Mais. Para preservar a identidade dos entrevistados, numeraremos os repórteres e trataremos todos os outros profissionais como editores.
} 
partir disso, analisar as informações e apresentá-las de forma estruturada. Em nosso trabalho, fizemos entrevistas presenciais. Todas as entrevistas realizadas constam dos Apêndices (do D ao Z).

\subsection{CORPUS EMPÍRICO}

Os três periódicos que fazem parte do corpus desta pesquisa são conhecidos no país por serem as referências quando se fala em prática jornalística para o tablet. O Globo A Mais e o Diário do Nordeste Plus, principalmente, por serem autóctones: terem equipe própria produzindo conteúdo e aproveitarem ao máximo as pontecialidades oferecidas pelo suporte. $\mathrm{O}$ Zero Hora Noite é atualmente o único que deu continuidade ao seu projeto e é um híbrido. Por isso, os três foram escolhidos e fazem parte desta pesquisa.

\subsubsection{O Globo A Mais}

O Globo A Mais nasceu com a missão de experimentar o jornalismo para tablets, mais precisamente para iPads. $\mathrm{O}$ aplicativo surgiu incentivado pelo expressivo crescimento no número de vendas dos aparelhos e como uma possibilidade testada pelo veículo de comunicação de levar conteúdo para o leitor de uma maneira diferenciada. Foi a primeira iniciativa brasileira com esse formato. A primeira edição saiu em 30 de janeiro de 2012. Era publicada de segunda a sexta, às $18 \mathrm{~h}$, por ser o horário que o leitor tinha mais acessos nos tablets e para não chocar com o horário de publicação do impresso, que é pela manhã.

Nos primeiros anos, o $O$ Globo a Mais era oferecido no mesmo aplicativo do jornal O Globo, que também reunia uma edição idêntica a do jornal impresso e o site, com a finalidade de integrar um pacote digital único, que permitisse ao assinante ter acesso a todo o conteúdo disponibilizado. Mais tarde, desvinculou-se dos demais produtos e passou a ser oferecido como um aplicativo próprio dentro da banca de revistas do iPad. Com a mudança de plataforma, O Globo a Mais também passou a estar disponível em dispositivos com Androide, para o Kindle e smartphones com iOS e Android (CUNHA, 2015). 
O produto seguia o formato de uma revista, para proporcionar ao seu leitor a acompanhar as notícias em formato digital sem perder a dinâmica da leitura do jornal impresso. O projeto gráfico foi desenvolvimento pelo escritório Cases i Associats, da Catalunha e tinha esse objetivo do dinamismo impresso, mas com fotos, vídeos em alta definição e uma forma facilitada de acompanhar o conteúdo. As publicações traziam reportagens exclusivas, somadas a textos opinativos de colunistas e conteúdos multimídias. Apesar do $O$ Globo a Mais seguir os mesmos princípios editorias do Globo, mas ele não seguia o noticiário do jornal, obtinha conteúdos exclusivos e diferenciados. Foi desenvolvido para ser um produto complementar. Seu redação não era integrada aos outros veículos.

O conteúdo principal era a Reportagem do Dia. Havia também colunistas que escreviam para o jornal e, alguns optam por fazer vídeo-colunas. Existiam seções fixas como Giro, um painel de notas com o resumo do que aconteceu durante o dia; galeria de imagens; indicações de filmes, livros, sites, programas, produtos de consumo, entre outros, quase sempre acompanhadas de conteúdo multimídia, como produções de mini-documentários, vídeos para acompanhar o trabalho dos fotógrafos entre outros. Mas para oferecer todo esse conteúdo, o grupo do O Globo utilizou de uma equipe de 14 profissionais para se dedicarem exclusivamente para $\mathrm{O}$ Globo a Mais, entre editoria, sub, repórteres, trainee e designers, sem deixar de integrar o trabalho com a redação do próprio impresso, contando com a participação de colunistas já importantes do veículo como, Mirian Leitão, Ancelmo Gois, Artur Xexéo e Merval Pereira.

Com poucos mais de três anos de existência o O Globo a Mais ganhou o prêmio Esso (que é a premiação mais importante do jornalismo brasileiro que existe desde a década de 1950) de melhor contribuição à imprensa, na ocasião a comissão julgadora justificou o resultado como um importante investimento da empresa no aperfeiçoamento da difusão de informação por meio de um novo formato.

Apesar da importância do aplicativo e da iniciativa inovadora, em 15 de maio de 2015, O Globo anunciou o fim da revista dos tablets O Globo A Mais. No artigo publicado no Observatório da Imprensa na edição 857, foi possível observar que o número de leitores do app não era pequeno - 35 mil downloads/mês, tendo chegado a 45 mil em janeiro 2015.

Apesar de não fazer parte da redação integrada, foi em setembro de 2008 que o grupo anunciou ao mercado a convergência, integração das redações, em O Globo. A campanha publicitária "Muito além do papel de um jornal" aprofundou um processo que foi iniciado em 1999 e estava em evolução desde então. Inicialmente existia uma sinergia de produção dos jornais, explica Barbosa (2009). 
"Desde Setembro de 2007, os editores do site passaram a participar das reuniões do Globo impresso, organizando o trabalho de forma que não haja desperdício de energia e que as duas mídias sejam de fato complementares" (BARBOSA, 2009, p. 4271).

Em março de 2014, o grupo volta a anunciar mudanças. O jornal passou a priorizar o digital. $\mathrm{O}$ expediente para alguns editores passou a começar às $8 \mathrm{~h}$ da manhã, com uma reunião de pauta (convergente) com todos os editores dos meios, que têm enfoque nas plataformas digitais (O GLOBO, 2014).

Apesar de fazer parte fisicamente da redação convergente do grupo multiplataforma, os editores do Globo A Mais não participam dessa reunião matinal. O produto é visto como premium pelos diretores e tem independência para produzir conteúdos diferenciados e exclusivos.

Para o Globo A Mais, a principal mudança nesta nova fase foi que deixaram de publicar conteúdos produzidos e veiculados no jornal impresso. O aplicativo tinha a primazia dos textos, publicando primeiro no tablet, para depois circular em outras plataformas. Com isso, o vespertino passou a contar somente com os textos produzidos pela redação do Globo a Mais.

A decisão é mercadológica e estratégica para o grupo. Os dirigentes acreditam que o tablet é uma ótima alternativa para gerar receitas. Para isso, os profissionais relatam que perseguem a conquista do leitor, buscando fidelizá-lo, apresentando novos conteúdos e com formatos diferenciados.

Por não fazerem parte do fluxo de produção integrada, os profissionais do Globo A Mais não trabalham com o sistema de controle de fluxo das edições, o News Gate. Há uma nítida resistência ao sistema entre os profissionais. Contudo, esse sistema serve, conforme o editor 1, em alguns casos, para acompanhar o que está sendo produzido e quais são os enfoques que são dados aos conteúdos. O site e o jornal também são consultados (MARQUES, 2015).

Vale ressaltar que o veículo O Globo, jornal que existe desde 1925 no Brasil começou seu investimento em meio digital em 1996 quando lançou sua primeira página na internet com a cópia do jornal impresso. Após esse período a empresa de comunicação investiu no meio digital e buscou entender o comportamento do seu leitor, paralelo à tradição do impresso. De olho no futuro, foi adotado o modelo Digital First, e apostou no modelo digital de se fazer jornalismo no qual aos poucos modificou sua forma de fazer jornal. No lugar da atenção voltada para o impresso, o jornal dedica-se às diferentes plataformas, sites, 
blogs, aplicativos, buscadores e passa a modificar suas rotinas de redação e principalmente as prioridades de trabalho.

\subsubsection{Diário do Nordeste Plus}

Com uma edição de segunda a sexta, publicada às $18 \mathrm{~h}$, o Diário do Nordeste Plus surgiu em 18 de janeiro de 2013. A ideia do produto foi posicionar a marca do jornal no segmento tablet e consolidar a presença dos meios digitais da empresa como um todo. A publicação digital contava conta com material exclusivo, com um resumo do que ocorreu de mais relevante durante o dia, vídeos produzidos pela TV DN, possibilita espaço para newsgames, dicas culturais com vídeos e áudios e reportagens especiais, tomadas como destaque na capa de cada edição.

A equipe inicialmente foi composta por um editor, uma editora, que também atua como repórter, uma repórter e duas designers. O conteúdo é pelos jornalistas da redação, inclusive o editor. Também colaboram colunistas da versão em papel.

O Diário do Nordeste é um diário da cidade de Fortaleza, fundado em 1981, por Edson Queiroz. Com uma tiragem média de 32 mil exemplares em 2013, está entre os maiores da região Nordeste. Foi o primeiro e até então o único de seus concorrentes regionais a investir numa edição exclusiva para tablets (CUNHA, 2015).

Muito dos materiais publicados por determinado repórter, sob regime de exclusividade para a edição digital, foram aproveitados também pelo Diário do Nordeste. Apesar de ter a redação integrada, inicialmente as equipes (editorias) só atuavam no online e no impresso. A produção do DN Plus era exclusiva para o suporte, contudo, os conteúdos poderiam circular em outras plataformas.

A parceria com a TV DN, plataforma multimídia do site do jornal, permite alimentar o DN Plus com vídeos. O conteúdo audiovisual, seja oriundo de fonte própria ou de outras fontes, precisa passar antes pela TV DN para que posteriormente seja publicado em qualquer plataforma. A decisão sobre o que deve ser publicado na edição do dia é tomada em discussão entre o editor do tablete, o editor do caderno que pretende publicar a matéria no impresso e o diretor de redação. Cada edição conta também com uma galeria de fotos (com até seis fotografias), com material produzido pelos fotógrafos do próprio jornal ou por agências. 
O desenvolvimento do design do DN Plus foi iniciado com dois meses de antecedência, sob responsabilidade de Eduardo Freire e Lincoln Souza, que tiveram de aprender do zero sobre as possibilidades interativas do tablet. Foi imposto o mesmo sistema de publicação já utilizado no site, o Digital Pages, que foi motivo de reclamação em função de seus recursos limitados e constantes problemas técnicos. Na sua implantação, cogitava-se alterar o sistema, mas até hoje continuam a utilizá-lo. A falta de experiência dos integrantes da equipe foi um empecilho para que pudessem entrar no ritmo de publicação e conseguir atingir sempre uma nova edição sempre às $18 \mathrm{~h}$ (CUNHA, 2016).

Em outrubro de 2015 o projeto é descontinuado e uma nova proposta do Diário do Nordeste Plus é lançado. De olho no mercado de celulares, o DN Plus passa a ser disponibilizado numa página web. Sua edição passou a ter apenas uma reportagem semanal.

\subsubsection{Zero Hora}

O ZH Noite foi lançado em 2015 como parte de sua estratégia em ambientes digitais. Publicado de segunda a sexta-feira, às $19 \mathrm{hrs}$, horário estratégico para que o leitor pudesse acompanhar os assuntos que foram notícia durante o dia, os últimos acontecimentos da noite e preparando as informações para o dia seguinte. Nele, é possível encontrar as mesmas seções do jornal diário. Através do aplicativo, o conteúdo pode ser acessado no computador, smartphones e no tablet. A modalidade também é produzida de forma alinhada com o impresso. Trabalham atualmente no verpestino dois jornalistas e o conteúdo é empacotado por esses profisisonais.

O jornal Zero Hora, também conhecido por ZH, foi fundado em 1964 na cidade de Porto Alegre no Rio Grande do Sul. Faz parte do conglomerado de mídia brasileiro RBS. Desde o ano de seu nascimento o jornal passou por modificações, seja no layout ou formulações de conteúdo. No ano de 1996, a edição e produção do jornal passa a ser totalmente digital.

Em 2007, entrou no ar o site ZeroHora.com, que apresenta notícias atualizadas 24 horas por dia e sete dias por semana. Em 2012, o jornal passou a cobrar pela versão digital do seu conteúdo impresso. No ano de 2014, o Zero Hora fez uma profunda reformulação editorial, gráfica e de marca. Tanto no papel quanto no online, em tablets e nos celulares as mudanças deram início a um ciclo de reposicionamento e transformação. Novos colunistas, 
cadernos reformulados, mudança de paleta de cores, tipografia, espaço para arte, ilustração e infografia, além de foco em vídeos.

Ainda em 2009, o jornal gaúcho já tinha seus cadernos fixos publicados no Kindle. Foi o segundo veículo brasileiro a ter espaço no suporte. Em 2011 foi disponibilizado para iPad, ainda com a interface do seu webjornal. Com o novo o site, desenvolvido em HTML5, o endereço passou a ser adaptável para navegação em celulares. Anos mais tarde o grupo lança o aplicativo.

Assim, como diversos grupos midiáticos, esse também passou pelo processo de transição do impresso para o digital até chegar à rotina de multiplataformas e multitarefas profissionais. No primeiro momento vivenciou procedimentos de repetição, utilizando assim os mesmos textos, chamadas e artes do impresso no digital, copiando e dividindo o conteúdo em ambos os formatos. $\mathrm{O}$ jornal atualmente adapta seus conteúdos às plataformas.

No Zero Hora, entende-se que a redação trabalha de forma integrada para o jornal impresso e online. Escrever para diferentes plataformas virou uma atividade rotineira para os jornalistas da redação. Esse trabalho de colaboração utilizado na produção integrada fez com que a atividade da Chefe de Redação do jornal passasse a ser de coordenação dessas divisões dos conteúdos, fazendo assim todos os profissionais da redação se tornassem multiplataformas. 


\title{
CAPÍTULO VI
}

\section{A CONVERGÊNCIA JORNALÍSTICA: UM OLHAR SOBRE A PAUTA COM FOCO NA INTRODUÇÃO DOS TABLETS NAS REDAÇÕES DIGITAIS}

\author{
6.1 ROTINAS PRODUTIVAS PARA TABLETS: A EXPERIÊNCIA DE O GLOBO A \\ MAIS
}

Publicado somente em dias úteis, O Globo A Mais nasceu em janeiro de 2012, como um produto jornalístico autóctone vespertino. Assim como todo produto dessa natureza, $O$ Globo A Mais possuía conteúdo específico e tratamento diferenciado para suas informações (BARBOSA et al, 2013). Os vespertinos criados na lógica do "a mais" deveriam buscar olhar o factual com uma nova angulação ou trabalhar temas diferentes, publicados no final da tarde. A ideia era fazer análises mais aprofundadas dos assuntos de que tratam. Para ter acesso aos conteúdos do periódico, que seguiria o padrão de uma revista, o usuário precisava comprar uma edição avulsa ou ser assinante mensal.

Apesar de fazer parte da mesma estrutura física da redação de $O$ Globo, G1 e da televisão Globo, a equipe do $O$ Globo A Mais não tinha sua produção integrada ao fluxo do Grupo. Trabalhavam no Globo A Mais seis repórteres, um editor, um editor-adjunto, uma subeditora, três designers e um estagiário. O horário de trabalho dos profissionais era de $11 \mathrm{~h}$ às $19 \mathrm{~h}$, podendo variar de acordo com a necessidade. O editor de fotografia multimídia, apesar de constar no expediente do aplicativo, não trabalhava lotado naquela redação, já que essa função atendia a todos os meios do Grupo. Quando eles precisavam de um vídeo mais elaborado ou de fotografias para alguma pauta, era necessário solicitar ao setor responsável um profissional para acompanhar o repórter ${ }^{50}$.

O vespertino era composto pelas seções Giro, Reportagem, Imagens do Dia, Colunas, Dicas a Mais e Imagem a Mais. Em todos esses espaços, apenas os colunistas eram fixos na produção do conteúdo e possuíam dias definidos para publicar nesses espaços. As outras matérias eram feitas por diferentes repórteres da equipe, em sistema de rodízio. Editores também podiam trabalhar na execução dessas tarefas, principalmente porque existia

\footnotetext{
${ }^{50}$ Em partes a convergência tecnológica era instalada. Contudo, nem todos os sistemas da redação eram usados pelos profissionais, como explicaremos no capítulo.
} 
um clima de colaboração na redação para o fechamento das edições.

A cada dia, um repórter ficava responsável pela seção Giro, que tinha formato de coluna com notas, gráficos, imagens e fotos randômicas. Considerada na redação como o trabalho mais "árduo", era o único espaço com natureza factual. Quem recebia a tarefa fica responsável somente por isso durante o dia. Procedia-se, como o próprio nome já diz, a um 'giro' entre os acontecimentos do dia. As informações eram retiradas, em sua maioria, de outras publicações na rede, e também as imagens eram coletadas de outros jornais da Infoglobo - "a empresa da mídia jornal do maior grupo brasileiro de comunicação, as Organizações Globo" (BARBOSA, 2009, p. 4270), principalmente de O Globo ou de agências de notícias. Os gráficos eram elaborados pelos designers do vespertino. Como se tratava de um conteúdo mais factual, aqui era o repórter que escolhia a informação, sendo revisada somente pelo editor.

A reportagem também era feita por diferentes repórteres. Geralmente eram pautas propostas pelos próprios profissionais, mas que podiam partir de qualquer membro da redação. Para a repórter 1 do O Globo A Mais (2014), o maior desafio de trabalhar no vespertino era escrever sobre qualquer temática. Como uma vantagem por trabalhar no meio, a repórter 1 cita a possibilidade de ousar nas propostas, fugindo dos assuntos corriqueiros do dia-a-dia, por meio de diferentes angulações. Os responsáveis pela reportagem deveriam também avaliar quais seriam as demandas a serem solicitadas: carros para externa, fotografias, vídeos e gráficos. Algumas informações e arquivos eram colhidos pelos profissionais na rede ou com as próprias fontes. Isso acontecia a partir da definição do deadline da matéria, depois da reunião de pauta de meio.

A seção Imagens do Dia era uma seleção de fotos feita por repórteres fotográficos de $O$ Globo, via de regra, a partir de agências. Na redação do O Globo A Mais, os jornalistas editavam as legendas e, algumas vezes, traduziam-nas. A explicação para as imagens serem de agências foi justificada pelo fato de os repórteres do periódico saírem com pautas específicas e por serem imagens que, esteticamente, se diferenciavam daquelas do dia-a-dia. Por isso, não haveria como serem produzidas pela equipe do vespertino ${ }^{51}$. Era implícita a necessidade de uma alta resolução e uma qualidade estética superior para que a foto seja publicada nos espaços.

Existiam colunistas fixos de $O$ Globo A Mais e também do grupo O Globo. Os formatos das colunas eram variados e algumas delas multimidiáticas. Por dia, eram publicadas

\footnotetext{
${ }^{51}$ Isso não quer dizer que os repórteres não possam fazer alguma imagem, inclusive no celular
} 
três ou quatro colunas. As abordagens eram livres e muitas vezes estavam inseridas somente no suporte. Dicas a Mais eram produzidas pelos repórteres e estavam relacionadas a atrações culturais. Elas surgiam de conversas entre os membros da redação e das navegações dos repórteres na rede. Cada um ia formando sua cadeia de fontes e compartilhando novas dicas. A última seção era Imagem a Mais, produzida com a memória de $O$ Globo. Geralmente um profissional ficava responsável por recuperar imagens do arquivo. Buscava-se também correlacionar, na medida do possível, a imagem escolhida aos fatos do dia ou à pauta proposta na edição.

Como a área de fotografia se tratava de um departamento que atendia a todos os meios do grupo, gerava-se certa 'tensão', em alguns momentos, entre o setor e a equipe de repórteres do Globo A Mais em virtude das necessidades do vespertino. Durante nossa observação, presenciamos uma discussão entre uma profissional do setor multimídia, uma repórter e um editor do Globo A Mais. Havia uma demanda da redação para a edição de um vídeo; a representante do setor multimídia afirmava que os arquivos não possuíam entrevistas (sonoras), por isso o material não poderia ser considerado um vídeo para o setor. Com isso, ela defendia a não edição do arquivo. A repórter argumentava que as imagens do vídeo continham elementos que as fotos não tinham e por isso ela gostaria de utilizar o vídeo com outro formato. Entre as possibilidades, ela sugeriu que poderia ter legendas. A responsável pelo setor de vídeo disse que eles estavam cheios de demandas e que solicitaria ao superior dela autorização para a edição do vídeo. Todavia, segundo a avaliação dela, o vídeo não valeria a pena: não tinha elementos e qualidade suficientes para publicação.

\subsubsection{Fluxo de produção}

O planejamento das edições semanais do Globo A Mais acontecia às terças-feiras, às 11h. É o dia em que nascia o que denominamos neste trabalho a Pauta Macro (ver mais no capítulo IV), uma pauta geral, para organizar os temas que serão abordados durante os próximos cinco dias da semana. Essa listagem era enviada para o editor-chefe do grupo ${ }^{52}$. O jornal possuía sua reunião própria porque não fazia parte da integração da redação. Apesar de ocuparem o mesmo espaço físico, as pautas não eram produzidas em colaboração com os

\footnotetext{
${ }^{52}$ Todas as edições possuíam independência de publicação. Não precisavam de aprovação para circulação.
} 
outros meios do grupo porque suas reuniões eram separadas. O desenvolvimento e produção dessas pautas era reticular, e as etapas de produção aconteciam de forma fragmentada e eram trabalhadas de modo não-linear.

Algumas pautas, devido à sua complexidade, recebiam um prazo maior para execução. De acordo com a editora 3 (2014), o alargamento do prazo muitas vezes era motivado pela apuração das informações e pela complexidade envolvida na produção de um conteúdo multimídia. Cada membro da redação podia e devia propor sugestões de temas diários. Não havia uma editoria definida para as pautas de cada dia, podendo-se tratar de temas variados em cada edição. Cada um escolhia a temática e apresentava o assunto. Geralmente quem apresentava, executava a pauta. Contudo, havia pautas mais trabalhadas, que demandavam mais de um repórter. $\mathrm{O}$ que os editores buscavam era um equilíbrio na escolha dos temas a serem publicados para não repetir assuntos.

A escolha dos temas ocorria por critérios tradicionais e novos. Atualidade, pertinência e relevância da informação eram observadas para se propor algo. Contudo, surgiam novos elementos que caracterizarão a noticiabilidade da informação: assuntos com potencial interativo e multimidiático tinham mais chances de inclusão no Globo A Mais, assim como a perenidade do conteúdo era observada. Ao escolher uma angulação, o fato de direcionar o foco para assuntos que pudessem ser lidos durante o final de semana era uma estratégia importante, como alertava o editor 3 (2014). Como se tratava de uma revista para dispositivo móvel, podemos dividir as abordagens de assuntos em dois tipos: 1) as que tratavam de temas mais factuais e 2) as que trabalhavam matérias frias. Em ambos os casos, a busca seria por uma abordagem diferenciada, com mais aprofundamento e detalhamento, feita por especialistas que analisavam os temas e dados sobre os fatos. A busca era por diferenciarse do que já era feito por outros meios de comunicação. Este era também um ponto singular.

Durante nossa observação, vimos que os repórteres não procuravam necessariamente o furo jornalístico, mas ele podia existir. O editor 1 (2014) acreditava que as fontes ainda consideravam os suportes digitais periféricos e isso dificultava conseguir informações exclusivas para a publicação. Isso não queria dizer que não pudesse acontecer, mas havia alguma resistência por boa parte das fontes. Antes da reunião de pauta, os repórteres já estavam buscando possíveis sugestões de temas. Os profissionais saem em busca de suas fontes para consolidar a proposta. A partir disso, davam início ao processo. Eles usavam os seus conhecimentos individuais, o conhecimento organizacional para escolher o que e como cruzar esse primeiro portão. 
Participavam da reunião de pauta meio repórteres, editores e um representante dos designers. Há, nesse sentido, uma redefinição da função dos diagramadores, que passavam a participar de forma ativa nas etapas de produção e ganhavam novas responsabilidades e competências no jornalismo. Não eram diagramadores que atuavam na redação, eram designers. Na palavra do editor 1 (2014), os designers ganhavam até poder de veto nas pautas. Nessas discussões, eles também tinham um papel de pensar nas possibilidades interativas do tema, sugerir novos e debatê-los, bem como, em parceria com os jornalistas, pensar na navegação da informação.

Para a editor 3 (2014), a pauta só existia se fosse multimídia. Ao olhar para uma informação - e ao propô-la como pauta -, o repórter precisava imaginar como pode ser apresentado o conteúdo. O enriquecimento, termo usado na redação para as matérias que exploravam as potencialidades do suporte, era uma condição central para aprovação de um tema de pauta. Nas palavras do editor 1 (2014), "enriquecer ${ }^{53}$ é adequar a matéria à ferramenta".

Depois dos temas aprovados, a pauta geral era criada em um arquivo no Google Docs, o que permitia que repórteres acompanhassem suas pautas. Alterações nesse arquivo eram feitas somente pelos editores. Era também no Google Docs, em um documento diferente, que o fluxo de cada edição, da produção diária, era acompanhado. A reunião de pauta, portanto, dava início ao fluxo de produção das edições. A partir dela, cinco etapas eram percorridas para a finalização de uma publicação, segundo o vocabulário da redação de $O$ Globo a Mais: a) pastas; b) diagramado; c) editado; d) liberado; e e) iPhone. Eram etapas que envolviam as fases de produção, edição e circulação da informação jornalística (WOLF, 2003) e consistiam em momentos formais para a produção de $O$ Globo a Mais, não do trabalho do jornalista. Dentro de cada uma delas, existiam diferentes etapas jornalísticas.

Alguns percursos abarcavam situações mais complexas, outros, ocorrências mais simples. Todos eram controlados numa tabela e possuíam um fluxo reticular (GRÁFICO 7). Quando uma célula era marcada, e não possuía nenhum aviso textual, era sinal de que aquela fase havia sido executada e os profissionais poderiam passar para um novo momento.

\footnotetext{
${ }^{53}$ Os jornalistas têm usado nas redações o termo enriquecimento para se referenciar a inserção de formas interativas, sejam de navegação ou mesmo de recursos para interagir com o usuário. A inserção de vários formatos midiáticos também é uma forma de enriquecimento.
} 


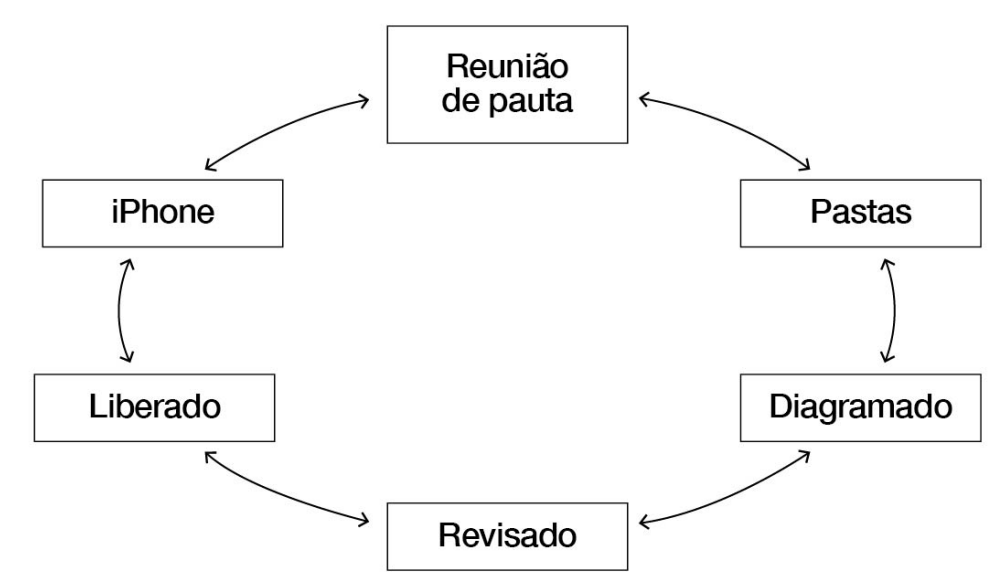

GRÁFICO 9 - Passos dados para produção de O Globo A Mais (produção própria).

Todos esses pontos eram feitos, na maioria das vezes, de forma silenciosa. Os profissionais ficavam conectados à tabela e dividiam, em muitos casos, a responsabilidade do fluxo, diferentemente das antigas e barulhentas redações. Como evidência do silêncio que imperava nesse processo, considerando que não tínhamos acesso à tabela, no primeiro dia de observação, não conseguimos perceber que a edição já estava publicada.

A primeira etapa da tabela era relativamente simples: pastas. Elas eram criadas por qualquer membro da redação, que abria as pastas para dar continuidade à produção. Era nelas que os repórteres iam salvando os arquivos de cada edição e, apesar de fazerem parte fisicamente de uma redação convergente, somente a equipe de $O$ Globo a Mais tinha acesso aos arquivos na rede.

As matérias que ganhavam destaque de capa possuiam, na maioria dos casos, arquivos produzidos pela redação. Vídeos e fotografias eram demandados de um setor específico de $O$ Globo, que produzia materiais audiovisuais. Nem sempre existia espaço para a produção de arquivos e muitas vezes os repórteres filmavam, tiravam fotos ou gravavam áudios nos celulares. Alguns desses arquivos entravam de forma original ou eram editados por um setor responsável.

\subsubsection{Pautas surgem, pautas caem}

Para que possa ser produzida para um dispositivo móvel, há uma grande alteração na forma de apresentar a pauta, acredita a repórter 1 (2014). O grande desafio para ela, que diz 
estar em transição da lógica do impresso para o tablet, era que "precisa pensar em vídeo, em áudio, (...) uma série de coisas que são uma novidade pra todo mundo". Além disso, era necessário refletir sobre como apresentar esses arquivos.

Muitas pautas surgiam na relação das fontes com os repórteres. Eram releases, navegações na rede, contato com fontes, principalmente utilizando comunicadores da web e mídias sociais. Dentre os entrevistados, também existia unanimidade ao falar sobre a influência das redes sociais na construção da pauta, pelo menos na hora do surgimento do tema. Em $O$ Globo, existia um informativo chamado Tá Quente, que é um tipo de resumo de temas que estão sendo recorrentes nas mídias sociais. Esse informativo é distribuído para todos os membros da redação e também era usado para pensar em novas pautas.

Métricas de acesso às edições não impactavam na produção das pautas. Apesar de os editores acompanharem os downloads das edições, não havia dados precisos sobre preferências de temas ou forma de consumo do aplicativo. Em outro trabalho, ventilamos que esses dados poderiam influenciar na produção das pautas (MARQUES, 2014b). O que se sabia na redação, conforme o editor 3 (2014), é que o consumo das informações se dá mais especialmente no período da noite, baseado na noção lean-back (GARCÍA, 2012). Segundo este conceito, é o tipo de leitura feita em posição confortável e com mais tempo, o que coincide com o horário em que o usuário está em casa, com mais tranquilidade para leituras mais aprofundadas.

A ausência de competência para o diálogo era considerado um limitador para se trabalhar no O Globo A Mais. Todo repórter precisava conhecer ou ter noções de arquitetura da informação e como melhor utilizar os formatos midiáticos para construção de uma narrativa. O momento para utilização desse conhecimento era a reunião de pauta, espaço de definição, de forma inicial, sobre os possíveis enriquecimentos, surgindo daí a arquitetura da informação. Apesar de a terminologia causar estranheza nos entrevistados, todos se mostravam preocupados com a navegação no conteúdo construído. Tratava-se de uma arquitetura compartilhada, que era desenvolvida por mais de um profissional, com culturas diferentes. O que se percebe é que se criou uma hibridização de conhecimento e todos acabaram utilizando o mesmo jargão para a execução das tarefas diárias. Tanto os jornalistas como os outros profissionais tendiam a se comunicar de forma transparente. Como é uma empresa jornalística, outros profissionais acabavam sendo incorporados pelas práticas diárias, acrescendo novos elementos ao habitus desses profissionais.

A responsabilidade de arquitetar os conteúdos era repartida com os designers, que pensavam juntos no desenvolvimento da página na qual o conteúdo seria alojado. Como, de 
regra, os formatos que seriam utilizados eram definidos na reunião, geralmente havia uma prévia de como o conteúdo seria apresentado. Entretanto, era na apuração que os repórteres se certificavam se a previsão se confirmara, já que algumas entrevistas e dados não rendiam o formato planejado. Caso não se concretizasse a apuração, o editor e os designers eram acionados, em tempos diferentes, para pensar em novas alternativas de cobertura.

O editor 2 (2014) afirmou que somente temas extraordinários tinham a capacidade de mudar as pautas pré-definidas. Um exemplo foi o acidente que levou à morte do candidato à Presidência da República, Eduardo Campos, em 2014. Apesar de serem evitados temas factuais, o editor ressalta que, quando esses assuntos eram abordados, o papel do vespertino era buscar uma nova angulação. Isso ocorria principalmente porque assuntos pulsantes não podiam ser ignorados, segundo ressalta o editor 3 (2014). Existia a possibilidade também de "caírem pautas" e, com isso, novos temas poderiam ser remanejados. Quedas aconteciam principalmente a partir de apuração e ausência de conteúdos (fotos, vídeos, áudios e recursos interativos), para enriquecer as matérias. Apesar de trabalharem com a possibilidade de haver “matérias de gaveta ${ }^{54,}$, nem sempre isso era possível. Durante a semana que observamos, não existiam matérias prontas para uma possível publicação.

\subsubsection{A produção multimídia para tablets}

Os vídeos em alta resolução não podiam subir em um tamanho máximo da qualidade por problemas de carregamento. Havia um limite de até 120 megabytes para subir o arquivo. E esse mostrou-se um dos problemas principais do Globo A Mais: a limitação de espaço para a produção de arquivos, que acabava deixando os jornalistas com uma capacidade reduzida para inserir muitos arquivos.

É importante destacar, contudo, que todos os arquivos precisavam ter uma boa qualidade. Vídeos, fotos e materiais com baixa qualidade só entravam se houvesse justificativa pela exclusividade e relevância da informação. O editor 3 (2014) afirmou que somente arquivos especiais, como de flagrantes, eram publicados nessas situações. Assim, a falta de qualidade era compensada pela importância. Existiam também os espaços em que os arquivos eram retirados da rede, como na coluna Giro.

\footnotetext{
${ }^{54}$ São matérias frias, que seriam usadas para publicação em caso de necessidade.
} 
Quando eram colocados nas pastas, alguns já começavam a ser trabalhados pelos designers, que tratavam e preparavam os possíveis arquivos. Muitas vezes, as capas iam sendo trabalhadas à medida que os arquivos chegavam. Essas capas iam sendo pensadas durante o fechamento das matérias e geralmente eram aprovadas pelos editores e pelo repórter que fez a matéria. Inicialmente as imagens eram discutidas e só depois diagramadas.

É interessante destacar que as capas exploravam também arquivos multimidiáticos. Sons e imagens randômicas já foram usados. Segundo o editor 1 (2014), o áudio é um novo elemento que acrescenta informações ao texto da capa. Ele explica que havia um cuidado redobrado para inserir o formato, principalmente em face de experiências passadas. Arquivos em flash eram evitados porque não podem ser executados em dispositivos da Apple. Quando usados, geralmente um aviso era colocado para que o usuário saiba da limitação.

Uma segunda etapa era: diagramado. A diagramação era feita a partir dos debates que ocorriam na reunião de pauta. Exposto o tema e pensados os formatos midiáticos que fariam parte do assunto, os designers passavam a refletir sobre a arquitetura da informação e a diagramação das páginas. Além dos parâmetros estabelecidos na reunião de pauta, sempre era observado o projeto gráfico inicial do periódico para a diagramação.

Muitas vezes, as ideias de páginas surgiam da navegação em outras edições, internas e externas, por parte dos designers e jornalistas, trazendo novas possibilidades de organização da informação. As potencialidades utilizadas em edições passadas também podiam influenciar nessa diagramação. Apesar de essa etapa ser feita de forma antecipada, era possível que, em alguns casos, fossem realizados ajustes, principalmente porque determinados arquivos podiam cair e alterações podiam surgir no processo de edição do conteúdo, ou mesmo certos elementos previstos podiam não render ou não ter qualidade suficiente para entrar na edição.

Concomitantemente à diagramação, os repórteres passavam a apurar os fatos definidos em pauta. A apuração era feita com as ferramentas tradicionais jornalísticas junto com outras mais recentes. Durante esse processo, alguns liam feeds de notícia, usavam a base de dados de $O$ Globo ou buscavam informações com suas fontes. Era comum também os repórteres utilizarem o Facebook e o Twitter, que estavam abertos durante todo o processo de produção das informações, servindo para acompanhar os acontecimentos e para encontrar e contatar fontes, além da localização de personagens.

Todos eram unânimes em afirmar que os processos de apuração continuavam os mesmos utilizados nos meios tradicionais. O que mudava, segundo os entrevistados, era a busca por formatos diferenciados, que acabava por forçar os jornalistas a desenvolver novas 
estratégias de captação da informação. A partir da disponibilidade da fonte, eles pensavam no modo como seriam produzidas as entrevistas.

Essa parece uma visão comum depois de todos os repórteres usarem mídias sociais e de terem uma participação mais ativa dos usuários servindo como fonte ou a forma que os conteúdos eram validados para o uso jornalístico. Também era invisibilizada a pressão que os assuntos debatidos na rede exercem sobre os assuntos que são escolhidos. Ao assimilar essas questões, os jornalistas apenas as incorporavam ao seu dia-a-dia sem perceber as alterações provocadas. Cabe destacar que existiam diferentes profissionais, com experiências e formação diferentes, atuando na redação e que isso podia ser também um dos motivos para a naturalização desses procedimentos.

Também foi possível presenciar os jornalistas utilizando comunicadores on-line para conseguir novas informações e agendar entrevistas. A todo instante, o Facebook e o Twitter eram consultados para atualização de informações. Com isso, verificou-se que a web era uma forte aliada para a produção das edições. A apuração de fatos também era feita em externas, principalmente para as matérias que ganharam destaque na capa.

Enquanto as matérias eram produzidas, existia um forte contato com os designers para continuar debatendo a organização dos conteúdos. A repórter 1 (2014) explica que nem sempre o que era pensado na pauta acontecia no fechamento das matérias. Em alguns casos, os materiais não ficavam bons e novas alternativas precisavam ser pensadas. $O$ uso de diversos formatos era uma orientação básica. Apesar disso, a repórter 1 (2014) diz que não havia uma determinação clara sobre o que usar e que isso se aprendia de forma automática ao trabalhar no suporte. Contudo, o repórter 6 (2014) acredita que alguns elementos são levados em conta ao escolher o formato que seria usado. Um deles era a pauta. Havia assuntos que pediam áudio, outros, vídeos. O que era levado em consideração era a informação que o arquivo passava. Em uma matéria sobre sons indígenas, por exemplo, foi utilizado áudio na capa. Ao se referir à pauta, o repórter 6 (2014) está querendo falar sobre o tema que seria abordado. Trata-se de uma competência necessária ao repórter ao defender o assunto. Saber qual era o melhor formato torna-se essencial para o aproveitamento e a validação do conteúdo na reunião.

Os repórteres que trabalhavam na edição comemoram o espaço ilimitado para escrever em $O$ Globo A Mais e dizem ter sido um diferencial do suporte poder narrar livremente, sem ter um tamanho definido. O editor 2 confirma que não havia limitação de tamanho. Para ele, o que devia existir era bom senso e escrever o necessário para a matéria. $\mathrm{O}$ que é possível observar é que as estratégias eram variadas e que cada um adotava um modelo. 
Como destacamos anteriormente, contudo, apesar de o tamanho do texto ser livre, havia limitação de tamanho dos outros formatos.

A preocupação com o usuário também influenciava nessa escolha. Textos longos e densos eram descartados pelos repórteres, que buscavam prender o leitor com o maior número de informações. "Eu procuro não fazer textos muito longos porque eu acho cansativo, mas um texto não muito longo pra mim é um texto enorme para o jornal” (REPÓRTER 2, 2014).

Apesar de o formato ser digital, havia um limite de matérias para a edição. O principal motivo era um entrave tecnológico e profissional. O tecnológico está relacionado ao tamanho do arquivo que era gerado, que não podia ultrapassar 120 megabytes. Com isso, existia uma preocupação em equalizar os formatos para não deixar a edição muito grande, causando demoras no carregamento das páginas pelos usuários. O segundo problema era o pequeno número de repórteres para fazer a edição diariamente. O tamanho da edição só era alterado no final de semana, quando o volume de matérias aumentava. O editor 1 (2014) acredita que por a edição ser pensada para ser lida durante todo o final de semana, mais matérias eram acrescentadas.

Não existia também um formato único de narrativa a ser utilizada pelos repórteres. Por não trabalharem com factual, os profissionais acreditam que não havia necessidade de utilizar o modelo de pirâmide invertida. O principal, para eles, era prender a atenção do leitor. A repórter 2 (2014) confia que colocar pontos importantes do início ao fim do texto seja a melhor estratégia de prender o leitor e fazer com que ele mantenha interesse em todo o material.

Quando o tema eram links, também não existia um critério claro para inserção. Os repórteres relatam que usavam links quando havia algo interessante a oferecer ao leitor. Todavia, cada um os introduzia de acordo com os seus critérios pessoais.

Finalizado o texto, era comum encontrar os repórteres inserindo e diagramando seus textos no InDesign, sendo essa também uma competência básica para atuar na redação do Globo A Mais, já que eles acabavam colocando seus arquivos nas páginas, nos mais variados formatos. Era comum também observar os repórteres escrevendo ou editando seus textos nas páginas. Apesar de ser um conhecimento necessário, ninguém passava por um treinamento específico para lidar com a ferramenta, aprendendo empiricamente no dia a dia.

Finalizado o texto, o repórter marcava a tabela do Docs e o material passava para uma nova etapa: edição. Os conteúdos eram editados pelos três editores, que também o faziam em silêncio. Apesar disso, cada um tinha seu estilo. No processo de edição, foi possível 
presenciar um editor dialogando com o repórter sobre o texto. Era possível relatar problemas, a necessidade de nova apuração ou mesmo parabenizar pelo produto final.

Quando algo precisava ser alterado, ou complementado, geralmente o editor solicitava ao repórter. Foi o caso da matéria publicada no dia 18 de outubro de 2014, sobre a Igreja Universal (IURD). O editor solicitou das repórteres envolvidas mais informações para a matéria, o que foi feito por três jornalistas. Efetuados os ajustes necessários, os designers eram avisados se existiam ou não mais mudanças a serem feitas.

A edição envolvia a normatização do texto - que seguia o manual de redação de $O$ Globo - a correção gramatical e das informações expostas e a angulação da matéria. As relevâncias da abordagem e o estilo textual também eram observados. Nesta fase, os editores criavam ou editavam títulos, chamadas, legendas, sutiãs e o índice dos textos. É importante ressaltar que algumas dessas etapas podiam ser feitas antes da conclusão das matérias. Tudo isso realizado dentro do InDesign.

Quando a etapa da edição era finalizada, partia-se para a fase seguinte: liberado. Isso significava dizer que os designers passariam a finalizar as páginas. Eles observavam os detalhes da diagramação, testavam se os áudios e vídeos eram executados perfeitamente e observavam a qualidade das imagens. Finalizados esses pontos, passavam a subir os arquivos aos servidores da Adobe. É importante destacar que não só os designers verificavam as páginas. Todos os membros da redação costumavam testá-las no Adobe Content Viewer, que gerava uma pré-visualização da edição. Era corriqueiro observar que a maioria deles testavam as páginas, observando o funcionamento das potencialidades.

O item iPhone representava a adaptação do conteúdo do tablet para a versão para telefone móvel. O formato possuía também linhas editoriais definidas. Contudo, quando não era possível fazer isso, o conteúdo produzido para tablet era transposto. Geralmente vídeos e áudios eram suprimidos por limitação tecnológica, já que o arquivo precisava ser menor. Em alguns momentos, havia também a necessidade de edição de títulos e sutiãs para a adequação do conteúdo. Nesse caso, os editores entravam em ação para reduzir o texto e essa adaptação servia para outras plataformas de mobile.

O Globo A Mais também era publicado na web de forma transposta e servia como vitrine para a venda da edição. Essa transposição gerava limitações em termos de potencialidades ao acessar a edição na rede. Havia também uma edição para Android, que obedecia à lógica de diagramação dos outros suportes. Quando a adaptação do iPhone era feita, essa era a versão utilizada. 
Como assinalamos anteriormente, o fluxo de produção do $O$ Globo a Mais é controlado no Google Docs. Todas as pautas da semana eram enumeradas no sistema. Sua memória de produção também passou a ser armazenada nesse espaço. Apesar dessa independência, havia contatos entre repórteres da redação de O Globo. Os editores também dialogavam com editores dos demais meios do grupo sobre a produção. O editor (2014) acreditava que, como o volume de informações na redação convergente é amplo, era um grande desafio produzir um conteúdo diferenciado, com novas informações nesse contexto.

Uma das vantagens de estar presente numa redação convergente é poder trocar ideias com repórteres de editorias especializadas, como economia, acreditava o repórter 6 (2014). A dificuldade de comunicação também é listada como um desafio nesse cenário. Havia momentos em que as pautas de O Globo a Mais colidiam com as de outras plataformas do grupo. Para evitar esse tipo de acontecimento, algumas delas eram conversadas com editores dos demais meios, mas esse procedimento não era algo muito recorrente. 


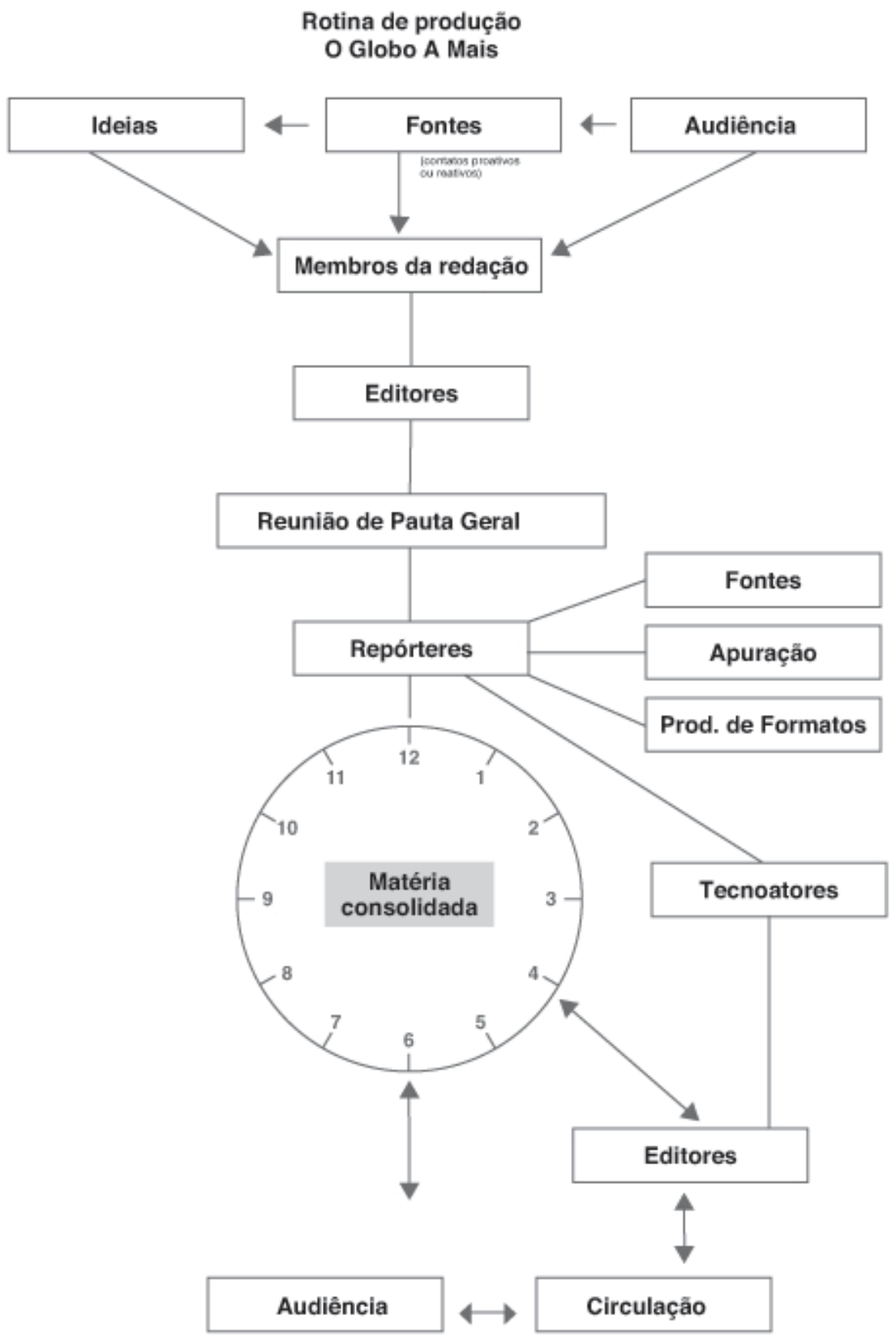

GRÁFICO 10 - Fluxo de produção circular de O Globo A Mais (produção nossa).

Sintetizamos no Gráfico 10 todo o fluxo de produção de O Globo a Mais, desde a ideia de matéria até a colocação em circulação do produto pronto. Nele, as pautas surgiam das ideias, fontes, sejam elas ativas ou não, e da audiência. Todos os membros da redação podiam propor pauta, inclusive os que não eram jornalistas. As sugestões eram feitas durante a reunião de pauta. Geralmente participava somente um editor da reunião e ele tinha o poder de veto. É importante destacar que designers também vetavam matéria, por incapacidade de 
enriquecimento. Neste reunião os repórteres também saíam com suas pautas direcionadas e durante o seu trabalho ela poderia ser alterada. Contudo, o editor precisava ser comunicado. Quando o trabalho era finalizado, o editor ia ler o texto e fazia as alterações necessárias. Quando era necessário mandava o texto de volta ao repórter para complementar o trabalho. Quando o conteúdo circulava geralmente não era mais alterado, mas foram relatados casos em que erros ou problemas menores, como falta de créditos em fotos, fizeram a equipe voltar a abrir o arquivo e consertar.

Em 15 de maio de 2015, O Globo anunciou o fim da revista dos tablets O Globo A Mais. Na última edição de $\mathrm{O}$ Globo a Mais o editorial afirmava que já estava em desenvolvimento um novo produto para tablets e smartphones. Contudo, até o fechamento desta tese, nada simular ao projeto foi lançado.

\subsection{ZERO HORA: A PAUTA VIVA NAS MÚLTIPLAS PLATAFORMAS}

A redação do jornal Zero Hora funciona em fluxo contínuo, em um ritmo de 24 horas nos sete dias da semana (24/7) e está integrada. O produto final desse fluxo é o jornal impresso, on-line, e as versões para mobile (ZH Dia e ZH Noite). A redação foi organizada em estações de trabalho, que são divididas por editorias e com uma mesa central, em que trabalham o editor-chefe, os editores de capa, os coordenadores de produção e a editoria de foto e vídeo. O impresso tem editorias fixas e outras, responsáveis pelos cadernos publicados durante a semana. Na web existe o portal e um sistema de $p u s h^{55}$, que é disparado para os assinantes em caso de informações que possuem relevância. O mobile possui duas versões ZH Dia e ZH Noite, que geralmente são acessadas em desktops e tablets - fora a versão para telefones celulares.

Como estratégia empresarial, algumas editorias do jornal foram agrupadas em 2014. A maior delas, e que acaba ditando um ritmo mais frenético à cobertura, é Notícias, que engloba política, economia, internacional e segurança. É a que produz um maior número de hard $n e w s^{56} \mathrm{e}$ é a única que possui dois produtores. As editorias Notícias, Cultura e

\footnotetext{
${ }^{55}$ Apesar de a newsletter ser também um produto enviado no estilo push, diferenciamos por ela ter uma periodicidade. Um sistema push serve para o envio de e-mails com alertas com consentimento do usuário, ou seja, ele precisa assinar a lista.

${ }^{56}$ Segundo a Folha de São Paulo, "“hard news" é o relato objetivo de fatos relevantes para a vida política, econômica e cotidiana".
} 
Entretenimento, Revista Dona e Esporte são iguais para todos os suportes do grupo: impresso, web e mobile.

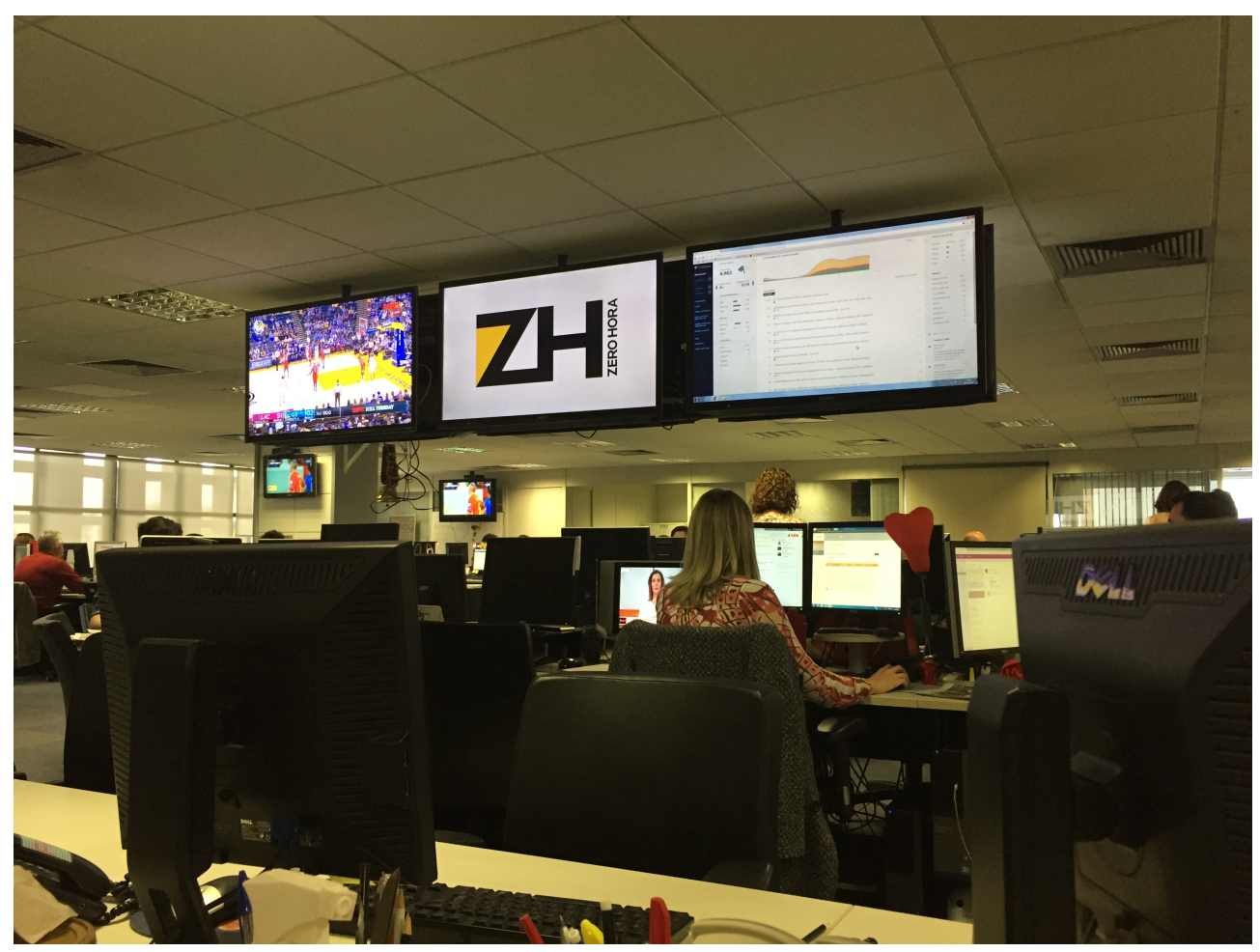

IMAGEM 1 - Mesa central da redação do Zero Hora (produção nossa).

Os dois produtores que trabalham no $\mathrm{ZH}$, profissionais jornalistas contratados para produzir pauta, exercem um papel organizativo e cumprem a mesma função que os primeiros produtores, quando os jornais foram organizados sob um modelo mais empresarial, na virada do século XIX para o século XX, como mostramos no capítulo II e IV. É importante destacar que os produtores de $\mathrm{ZH}$ não assumem a mesma função dos produtores de televisão - fazendo contato com fontes e agendando entrevistas. Esse trabalho é dos repórteres. Na Zero Hora, são os produtores que fazem a pauta e distribuem para todos os membros da redação, principalmente os editores que participarão da reunião de pauta convergente. Geralmente, os produtores constroem a pauta no dia anterior e já direcionam qual repórter fará a cobertura do tema. Eles fazem essa escolha a partir do perfil e especialidade de cada profissional para a cobertura, mostrando que as habilidades e o capital formado nas redações são fundamentais nesse processo. Os produtores têm autoridade para demandar a atualização de matérias que estão sendo mais acessadas no site. Fazem também a escala de folga, férias e plantões. São 
encarregados de distribuir, via e-mail e dentro do Newsroom $2000^{57}$, a pauta geral ${ }^{58}$ para todos os editores. Durante o dia, ao sair o espelho do jornal impresso, entram em contato com as editorias ou com o repórter encarregado para informar o tamanho que será necessário para as matérias que serão publicadas na versão de papel.

Como o jornal possui a redação integrada e a produção é cross-media, a pauta serve inicialmente para indicar os conteúdos que serão cobertos. É na primeira reunião de pauta integrada, entre $9 \mathrm{~h} 30$ e $10 \mathrm{~h}$ da manhã, que a pauta feita pelos produtores será debatida e fechada para que os repórteres comecem a trabalhar. Todas as editorias do jornal são contempladas com essa pauta, inclusive com direcionamento para cobertura de mídias sociais, vídeos e fotografia. A editoria de Vídeo produz conteúdo também para as matérias, além de gerar documentários. A editoria de Mídias Sociais, além de ser pautada, também dá alertas sobre temas que estão gerando muita repercussão na rede, ou seja, pode gerar pautas de conteúdo. Além de se debater as propostas dos produtores, editores também trazem novas sugestões.

Segundo o editor 3 (2016), "a pauta vem de todos os lugares e da vivência do jornalista, das leituras do jornalista, das conversas que ele trava”. Ela é o eixo central no qual se organiza toda produção do jornal. No Zero Hora a pauta começa a ser formatada na véspera e será executada no dia seguinte. O planejamento se dá na véspera com as principais apostas para o dia seguinte, principalmente para não ocorrer de o jornal não ter a mínima ideia do que poderá ser notícia ou manchete. São definidas as apostas de foto de capa, por exemplo, para o site ou impresso. Em função da pauta vai sendo construída toda a produção do jornal: os esforços para garantir a manchete, as fotos de capa, as outras matérias que vão rendendo manchetes ao logo do dia no site. O produtor 2 (2016) diz que a pauta "é o eixo central porque é em função dela que os repórteres, fotógrafos, editores e os profissionais de vídeos e imagens vão trabalhando."

$\mathrm{O}$ editor 3 do $Z H$ explica que, em um ambiente multiplataforma, a pauta é uma espécie de fio condutor, espinha dorsal da cobertura. "Em alguns momentos do dia, a gente tem momentos de parar para pensar e ver como ela está”, diz. Ele explica que ela conduz tanto quem produz o conteúdo, quanto quem acessa, o usuário. Ao ampliar o tema e buscar originalidade no assunto, o repórter estaria buscando moldar, esculpir a pauta. Esse

\footnotetext{
${ }^{57}$ O Newsroom 2000 é um software desenvolvido para o impresso. É o local em que as matérias são produzidas pelos repórteres, bem como é o local em que os editores leem e fazem observações sobre os textos. É nele também que os produtores acompanham as páginas que terão disponíveis no impresso. A pauta geral fica disponível também neste espaço.
} 
movimento daria mais relevância ao periódico, mais repercussão entre os concorrentes e a audiência. O objetivo seria "tornar a abordagem mais útil para o leitor, tentar dar um olhar original para a pauta. Não para ser original por ser original, mas para ter a commodity da pauta, mas ter um olhar diferente da pauta.”, afirma o editor 3 (2016).

E ela necessariamente é um ente vivo que tem que tá toda hora mudando, toda hora sendo espancada, toda hora sub judice para que ela se adapte aos fatos do momento e ao mesmo tempo à missão que a gente tem como marca, de produzir conteúdo interpretativo, de produzir tendência, de dar furo, de ter o breaking news, de ter um pacote de $360^{\circ}$ de formatos de notícia, tanto no aspecto do sujeito acessar o conteúdo, do jeito certo. (EDITOR 3, 2016)

O editor 3 (2016) acredita que a pauta mudou muito, em função das próprias mudanças na redação. Para ele, “o jornal sempre teve um ritmo frenético, contudo, este compasso aumentou, deixando de ser um jornal para se transformar numa usina. [...] A redação é uma usina de produção de conteúdo em diversos formatos, em diversos tamanhos, para diversas plataformas, em diversos níveis de profundidade de leitura, com diversos tempos de produção, com muitas coisas sendo feitas simultaneamente" (EDITOR 3, 2016). Ele acrescenta que toda essa transformação é reflexo do mundo e os profissionais, os jornalistas, apenas se adequaram às necessidades.

\subsubsection{Reunião programada}

A primeira reunião de pauta do dia é sem dúvida a mais importante para a edição. Nela se estabelece o que tende a ser chamado no $\mathrm{ZH}$ de jornada do leitor ${ }^{59}$, com os horários de publicação dos textos e as matérias que serão apostas durante o dia. A jornada é construída, segundo o editor 3 (2016) “a partir de dois referenciais: um é a vida real, o que tá sendo produzido, o que está acontecendo, quando podemos publicar tal coisa, quando devemos publicar tal coisa porque se não publicarmos estaremos atrasados. E o outro é o comportamento do leitor acessando os conteúdos."

Nesta primeira reunião participam todos os editores que trabalham por temáticas, e editores de Fotografia, Artes e Mídias Sociais. Os editores de Arte nem sempre estão

\footnotetext{
${ }^{59} \mathrm{O}$ termo é usado para descrever uma linha do tempo de produtos jornalísticos que serão publicados ao longo do dia. Esta é uma estratégia criada pelo grupo para fidelizar a audiência. As métricas são balizadores importantes para avaliar a jornada diária
} 
presentes na reunião. Como existe uma grande demanda para $\operatorname{arte}^{60}$, e normalmente todos estão sempre muito ocupados, eles nem sempre comparecem e quando é necessário são convocados.

Nesta primeira reunião de pauta do dia, todos expõem a aposta do dia. A aposta do dia são assuntos que renderão mais no decorrer do dia e que poderão virar manchete. Geralmente este assunto é, na linguagem da redação, mais "espancado". São os temas mais debatidos e que produzem maior número de arquivos e perspectivas de cobertura, com angulações diferentes.

A reunião começa com o relato, na maioria das vezes, do coordenador de produção, apresentando as métricas das matérias do dia que estão publicadas no portal. Para isso, o jornalista assume um computador acoplado a uma televisão para que todos os participantes da reunião acompanhem os números de acesso dos conteúdos. O editor 3 (2016) afirma que, se o comportamento do leitor pode ser rastreado e identificado e em determinados horários o assunto $\mathrm{X}$ é mais procurado, convém que o jornal produza para aquele horário.

Nós dividiremos neste trabalho as métricas em internas e externas. Os dados internos servem para dar indicativo de matérias que estarão na capa dos meios que fazem parte do grupo. Chamamos de (dados) internos porque são números relativos à produção do Zero Hora. Tanto jornalistas, nos seus mais variados cargos, como um setor de métricas ${ }^{61}$, produzem e acompanham um relatório diário com os números do jornal. Os dados que os jornalistas observam são extraídos pelo Chartbeat ${ }^{62}$. As principais matérias são comentadas e pensadas em possíveis atualizações ou suítes, já que o assunto está sendo buscado pelo leitor. Outro conjunto de dados diários e semanais é fornecido jornalistas durante a reunião de pauta. Eles são provenientes do Google Analytics e separados por matéria e editoria, fazendo-se um comparativo com a semana anterior. Os jornalistas interpretam desses dados buscando compreender o atual cenário de acesso. Dessa forma, pensam como aumentar os acessos da semana.

Os dados externos são responsáveis por propor novas matérias ou possíveis atualizações de conteúdo já produzido. Nem sempre um novo conteúdo é produzido, alguns são atualizados. Nesse caso, o segundo programa consultado é o Google Trends. Este é um dado externo, fornecido pelas buscas feitas pelo Google. Não há uma imersão nas palavras

\footnotetext{
${ }^{60}$ A editoria de arte engloba designers e programadores.

${ }^{61}$ Este é um setor que fica a baixo da redação.

${ }^{62}$ Disponível em: < https://chartbeat.com/>
} 
mais buscadas, ela é feita de forma superficial. Os jornalistas procuram acompanhar quais são as temáticas, se eles já produziram algo sobre o tema e se este pode ser executado.

O produtor 2 (2016) frisa que, pela experiência do jornal, eles já sabem que determinadas temáticas são ruins para a audiência no site, mas não podem abrir mão de produzir o conteúdo pela relevância do tema. O que não quer dizer que isso vá acontecer com todos os suportes. "[Há] pautas, por exemplo, que a gente sabe que vão render só algumas linhas no impresso, mas para o site terão uma visibilidade maior, em função do tema ou pela disponibilidade de vídeo, infográfico ou quiz".

Feita essa repassagem sobre os números de acesso, o editor de Notícias ${ }^{63}$, maior editoria do Zero Hora, passa a expor as sugestões de temas que serão cobertos ao longo do dia. Existem dois produtores na redação e eles são responsáveis por preparar as pautas do dia e da noite para manter a redação funcionando 24/7. Destacamos que há uma forte interação entre o trabalho dos profissionais que são produtores e é nítido que funciona de forma sincrônica. Um entra no começo da manhã e o outro no final da manhã $\tilde{a}^{64}$.

A aprovação das pautas sugeridas segue uma lógica, como falamos anteriormente, de construção do que eles denominam jornada do leitor. Este termo é usado para se referir aos assuntos que serão publicados ao longo do dia. Para isso, o editor-chefe cria uma timeline, num quadro com o tema e o horário em que os conteúdos são sugeridos pelos editores. Dentro desses temas figura a aposta do dia - matérias que serão melhor trabalhadas e renderão capas para o impresso, online e a versão para os tablets. Nas reuniões que acompanhamos, o foco ficou na capa do online e do impresso.

Então, a reunião de pauta é o lugar em que vem para cima da mesa tudo isso, os insights do dia, o que está acontecendo, quais são os fatos, o que não podemos deixar de publicar e o que nós decidimos que vamos hoje publicar. As ideias que temos de abordagens e, de outro lado, qual o melhor momento de publicar e qual o melhor formato, levando em conta o comportamento de leitura das pessoas. [...] A gente só distribui os conteúdos de uma maneira que caiba na nossa capacidade de produção e que se publique na hora certa em relação ao tempo da notícia, ao tempo do fato. (EDITOR 3, 2016).

O pauteiro da manhã, chamado na redação de produtor, é o encarregado de consolidar a pauta matutina. Ele recebe do outro produtor vespertino uma listas de temas que serão apostas para o próximo dia e que já foram cobertos no dia. O papel do produtor diurno é atualizar os temas, observar as angulações e complementar o trabalho do colega do outro

\footnotetext{
${ }^{63} \mathrm{Na}$ última reformulação editorial do jornal, em 2012, foi criada a editoria de notícias que lida com política, economia, internacional, segurança e temas mais factuais.

${ }^{64}$ Para organizar melhor a explicação, chamaremos de produtor vespertino ou pauteiro vespertino.
} 
turno. Ele busca compreender também o que já foi publicado durante sua ausência e vê o que precisa ser atualizado. Já chega à redação atualizado, mas ao se sentar à sua mesa fica atento aos conteúdos de rádios, televisão, impressos e sites na web. A pauta vespertina é seu balizador, ele precisa atualizar o conteúdo e conta com essa atualização para isso. É importante destacar que o olhar regional sobre as pautas é um esforço coletivo de todos na redação.

A pauta preparada pelos produtores é composta por datas e dia, nomes dos repórteres, editorias e pautas que cobrirão. Uma listagem de matérias que serão aposta do dia e a situação em que se encontram em termos de execução. Existe também uma listagem de matérias que estão em produção e a previsão de quando estarão prontas. Por fim, indica também os repórteres que estão de folga no dia.

\subsubsection{Sequência da reunião}

Quem apresenta as sugestões geralmente é a editora de Notícias. Na ausência dela, os produtores apresentarão as propostas. Durante essa exposição, na maioria das vezes, somente a angulação da cobertura e horário previsto de publicação são expostos. Em alguns momentos os presentes propõem novos caminhos e discutem fontes. Existe também o questionamento sobre qual seria a novidade nesta cobertura. À medida que a editora vai apresentando, a jornada do leitor vai sendo preenchida. Dependendo do interesse pelo assunto, o horário de publicação pode ser deslocado para mais tarde ou mais cedo.

Não é possível afirmar que há uma sequência rigorosa na ordem de apresentações dos editores. Das reuniões que acompanhamos, somente não variou a apresentação da editoria de Notícias, que possui um número maior de repórteres e geralmente é quem emplaca mais manchetes ao longo do dia em todos os suportes. Sua Vida, Cultura e Entretenimento e Esporte são as outras editorias que expõem pautas e horários e cobertura. Mídias sociais e Videos também apresentam sua agenda e acordam possíveis coberturas.

Apesar de não serem integradas a outros meios do grupo, o ZH recebe diariamente a pauta das rádios, televisão e jornal impresso de outras regiões e elas são balizadoras também para produção do conteúdo. Quando conseguem usar algum material dos colegas ou aproveitar a presença do repórter da rádio, por exemplo, eles o fazem. Cobrir uma entrevista de uma personalidade importante em outro suporte também acontece. Foi o caso de 
entrevistas na Rádio Gaúcha, em que repórteres fotográficos, repórter na redação e mídias sociais fizeram a cobertura.

De acordo com o editor 3 (2016), a reunião de pauta é um momento de parada para olhar os fatos que acontecerão no dia, com a tentativa de submeter esses acontecimentos a uma lógica de produção. Com isso, concilia-se a capacidade de produção, fazendo um pacto entre as editorias para equilibrar os conteúdos entre elas, tentando conciliar conteúdo com horário de publicação. $\mathrm{O}$ editor 3 define o momento como "uma convergência grande para tomar macrodecisões, que estão sujeitas a mudar ao longo do dia, mas que são um vetor, um norte para as editorias atuarem nas próximas 24 horas".

Quase todos os presentes na reunião de pauta são jornalistas e sempre devem opinar para ampliar e melhorar a cobertura do assunto. Somente a editoria de Arte, que participa esporadicamente das reuniões, não tem formação na área. Os representantes da editoria de Arte ouvem as demandas da redação e apresentam seu ponto de vista. Podem também sugerir pautas e vetar ideias dos editores. A inviabilidade da produção de algum conteúdo pode derrubar uma pauta. Entender da cultura jornalística parece ser um ponto fundamental para que esse diálogo aconteça. Os jornalistas também demonstram ter noção das limitações no desenvolvimento de programação e artes.

Para o editor 3 (2016), esses tecnoatores interferem de várias maneiras no processo de produção jornalística. Ele explica que uns dos principais entraves nessa relação é o tempo, que não é o jornalístico. Para resolver isso, o Zero Hora tem buscado criar conteúdos complementares que a urgência de cada suporte exige. A realidade, para o editor 3 (2016), é que cada vez mais surgem profissionais híbridos, com múltiplas habilidades.

[Existe] a capacidade de interferência, para o bem e para o mal, de áreas que não são genuínas, assim, de jornalistas; editores, que são designers, que são programadores, que são editores de vídeo. São pessoas que são da área de comunicação, têm o tempo das coisas, conhecem as coisas, conhecem esses insumos, esses empacotamentos jornalísticos melhor do que o jornalista. (EDITOR 3, 2016).

Existe dificuldade no diálogo entre esses profissionais, as áreas de atuação, na redação e o editor 3 (2016) acredita que seja natural. "E existe [dificuldade] de toda ordem, inclusive resistência de alguns jornalistas em aceitar a invasão desses outros profissionais, dessas outras disciplinas dentro do ambiente de redação." O papel dos editores agora também é gerenciar esses conflitos para que os trabalhos andem.

A editoria de Vídeo tem um duplo papel na reunião. Além de anotar as demandas individuais de cada editoria, ela também produz vídeos específicos de pautas. Eles podem ser 
uma simples sonora (entrevista gravada) ou um documentário mais elaborado. Os formatos sempre dependerão da pauta. Os profissionais que participam dessa editoria precisam ter habilidades distintas, como gostar de fazer roteiros, produzir boas imagens e distinguir qual tipo de arquivo gerar. Nem sempre são jornalistas que trabalham na editoria. Como são produzidos conteúdos para diferentes suportes, existem pautas que são direcionadas por se adequar melhor ao tipo de plataforma. O produtor 2 (2016) explica que a produção online é muito maior que o impresso.

A editoria de Mídias Sociais também acompanha a reunião. Geralmente não sugerem pautas, mas a Editoria saí pautada para fazer a cobertura de determinados assuntos. Repórteres costumar enviar alguns arquivos com antecedência e estes são publicados na rede e fazem divulgação do que foi publicado e o que será.

Formada a jornada do leitor, com a aprovação do editor-chefe, os editores passam a demandar os repórteres ou a acompanhar o trabalho que estava sendo desenvolvido. Muitas das matérias que são expostas na primeira reunião do dia já estão sendo trabalhadas pelos repórteres desde cedo. Elas surgem de um direcionamento do produtor da tarde, que deixa uma primeira versão do trabalho (pauta?) pronta e que não poderia esperar a próxima reunião por causa do horário. O que os editores farão em seguida, depois da reunião da manhã, é buscar saber como está o trabalho de apuração e como o texto evoluiu. É possível também que novas demandas sejam repassadas.

O editor 3 (2016) explica que os conteúdos das pautas podem ser alterados na reunião, inclusive a ordem de importância de cada conteúdo: “A reunião de pauta, na verdade, referenda a hierarquia ou muda a hierarquia. E cinco minutos depois da reunião de pauta, se acontecer alguma coisa, de novo a gente muda a hierarquia". Não com uma nova reunião, mas com micro-reuniões na própria redação que acontecem entre editores e às vezes com repórteres. "Assim, a reunião de pauta constrói a hierarquia a partir dos insights que as editorias trazem e as editorias também têm as suas dinâmicas de reuniões." Para uma pauta ser aprovada, o assunto precisa ter interesse público ou ser de interesse do público. "Achamos mais importante oferecer o que é de interesse do leitor", diz o produtor 1 (2016). Esse é o primeiro ponto que decide a aprovação de uma pauta. O segunda ponto citado é a originalidade, a tentativa de encontrar um ângulo diferente acerca do mesmo assunto, para que ele possa ser explorado por outras plataformas.

Uma instância que concentra grande capacidade de alteração dos assuntos originalmente sugeridos é o momento de apuração. Para o produtor 1 (2016), no jornal Zero Hora existe um respeito muito grande pelo que o repórter apurou. "Para mim, a instância que 
mais muda matéria é o momento da apuração", diz ele, acrescentando que o repórter sempre pode melhorar a pauta. Além de sofrer mudanças, a pauta também pode cair. O produtor 2 (2016) acredita que os motivos para isso são diversos. Em alguns casos, a pauta não se sustenta: “Às vezes, se tem uma ideia, mas na vida real ela não é assim”. Em outras ocasiões, isso se dá porque a proposta reduz de tamanho, de abrangência. Contudo, ele alerta que são raras as vezes em que as matérias caem por completo. A falta de repórter ou fotógrafo pode levar a isso.

\subsubsection{ZH Noite: o fechamento da edição}

Os repórteres do Zero Hora Noite chegam à redação entre $11 \mathrm{~h}$ e $12 \mathrm{~h}$ da manhã. A jornada diária deles começa lendo a pauta geral que fica disponível no Newsroom ${ }^{65}$, além de acompanhar o que foi publicado no portal e nas mídias sociais do grupo. É a partir dessa leitura que eles começam a inserir na retranca ${ }^{66}$ as informações que farão parte da edição do dia. Os jornalistas do ZH Noite fazem um trabalho de curadoria, selecionando conteúdos para publicação no suporte. Feitas essas escolhas, os dois profissionais copiam os conteúdos que interessam nessa edição e passam a editar para adaptar a versão.

Entre $15 \mathrm{~h}$ e $15 \mathrm{~h} 30$ acontece uma reunião de pauta do aplicativo $Z H$ Noite. Podemos classificar como reunião de meio ${ }^{67}$, com especificidade de quem só empacota ${ }^{68}$ o conteúdo. Participam dessa reunião uma editora de capa, que está presente na primeira reunião de pauta integrada, e os dois repórteres específicos do ZH Noite. Apesar de o expediente do aplicativo mostrar que há um editor e uma repórter, nas reuniões e no trabalho do dia-a-dia essa hierarquia não transparece. O conteúdo que é publicado no aplicativo é aproveitado do jornal online e no impresso e há uma relação dialógica entre os dois.

\footnotetext{
${ }^{65}$ Outros softwares usados pelo ZH: News 2000 é ferramenta de escrita do $Z H$; a ferramenta para baixar fotos chama-se Nica; o Indesign é para diagramação e o Marvin, que funciona como servidor local, é usado para inserir as páginas do $\mathrm{ZH}$ Noite. Quando surgem temas em cima da hora, o $\mathrm{ZH}$ tem um recurso chamado $D i$ Ultima Hora, que é uma parte colocada na porção inferior da capa, com uma frase em amarelo - chamada com um resumo do acontecimento de última hora.

${ }^{66}$ Este é um jargão jornalístico que pode ser referir à manchete da página ou a uma matéria subordinada. Neste caso é uma listagem de matérias que estarão presentes na edição.

${ }^{67}$ Apesar de fazer parte de uma redação integrada, a reunião de meio neste caso serve para referendar a pauta organizativa.

${ }^{68}$ Empacotar significa colocar adequar o texto ao suporte.
} 
Cada edição do ZH Noite ${ }^{69}$ possui um número de páginas sempre igual: nove páginas de conteúdos e uma de anúncio. As páginas são montadas pelos repórteres e desenhadas com os diagramadores. Quando os assuntos são extraordinários, duas páginas são separadas por matéria. A integração da redação acaba ajudando os membros da equipe, que podem tirar dúvidas com outros profissionais. Depois de prontas no sistema, os repórteres solicitam ao setor a criação das páginas. Elas são diagramadas e voltam. Ao voltar, eles ajustam os títulos nas páginas e passam o conteúdo a um colega ou mesmo à revisora. Quando a revisora entrega a página impressa em formato A3 com observações, eles consertam as observações e passam para uma nova etapa.

Esta etapa tratará de inserir os links, depois da página diagramada. Os vídeos são feitos pelos repórteres fotográficos e controlados por uma editora, que os distribui por todos os suportes do grupo. Durante o fechamento do ZH Noite os links são inseridos e testados. Feitas essas inserções e testes, os arquivos são colocados em pastas para entrar na memória do jornal. Eles também geram arquivos em imagens para serem passadas para a editoria de mídias sociais para divulgação. Informa-se também num arquivo em Excel que a edição foi fechada e pode ser enviada em push.

Como dissemos, os repórteres consultam a pauta consolidada e vão em busca das matérias para empacotar. Elas são escolhidas pelo critério de proximidade e por possuir maior diversidade de formatos. Temas mais atuais, como os relacionados a jovens e que possuem boas imagens ou vídeos tendem a entrar com mais facilidade. Esporte também é unanimidade na versão: sempre há muito acesso.

Na reunião do meio, os dois membros da redação do $Z H$ Noite vão expondo o que pensaram para a edição do dia e passam a debater com a editora de capa do jornal. Não há produção deles. O que os dois profissionais fazem é adequar os conteúdos produzidos para o site ou para o impresso, que é visualizado no sistema, e para fechar o ZH Noite. Para o repórter 1 Zero Hora Noite (2016), a função deles no aplicativo é transformar as matérias produzidas em um conteúdo leve para o leitor. Trata-se de, na maioria das vezes, de um conteúdo factual, com informações de fatos que ocorreram nesse dia. "Nossa função é condensar esse material e montar um resumo do dia para que fique claro na cabeça do leitor o que aconteceu."

Para escolher a capa do jornal, é fundamental pensar quais serão as capas nos outros suportes. Há uma tentativa de usar temas mais próximos da cidade. Na contracapa, por

${ }^{69}$ O Zero Hora Dia é uma versão ampliada do Zero Hora Noite, só que publicado nos finais de semana. Por ser maior, essa edição conta com a colaboração de outros jornalistas da redação para o fechamento. 
exemplo, existe uma galeria de imagens que busca trazer fotos regionais. As galerias são feitas pelo editor, que puxa as fotos do sistema. Quando não há um conteúdo interessante para o aplicativo, eles demandam algo especifico ao editor. Tudo isso é decidido na reunião de pauta.

O repórter 1 (2016) acredita que agilidade é uma qualidade necessária para atuar no ZH Noite. Essa agilidade é alcançada trabalhando em outras editorias do jornal. "E acredito que uma experiência com o digital conta também. Já que o ZH Noite é uma mistura dos dois. Ele é um produto digital com ares de impresso."

As métricas têm influenciado de alguma forma a produção de conteúdo no ZH Noite. Não é um recurso que é acompanhado diariamente pelos dois membros da equipe, mas o que eles escolhem já faz parte de um conteúdo pensado por intermédio dos dados. Nesse caso, quem sabe mais dos dados é a editora de capa.

Os conteúdos multimidiáticos estão incorporados no dia a dia da redação. O que acaba acontecendo muito é a inserção de um vídeo ou só a galeria. É possível que, na ausência de arquivos, os jornalistas acabem pedindo para a editoria de Fotografia produzir uma imagem adequada. No fundo, eles ficam dependentes do conteúdo que é produzido pelas editorias e usam o que há disponível.

Apesar de se tratar de um produto para dispositivo móvel, o repórter 1 do ZH Noite (2016) acredita que não há diferença no texto. Contudo, a busca é por deixar o texto mais leve e compacto. "Mais direto e mais objetivo. [...] Mais é a nossa proposta; apresentar o factual do dia sem qualquer discussão." Existe, de alguma forma, uma preocupação quanto à interatividade do usuário com o conteúdo. A ideia, para os repórteres do aplicativo, é sempre ter o máximo de formatos de mídias. "O texto, a foto, o vídeo e a galeria. Perfeito. Tudo isso mesclado é a matéria perfeita. Nem sempre a gente consegue”, afirma o repórter 1 (2016).

\subsubsection{A terceira reunião: o fechamento e a preparação do próximo dia}

À tarde, o ritmo na redação do Zero Hora não diminui, mas muitos repórteres estão na rua fazendo suas matérias e a sensação, no começo da tarde, é de mais calma. Editores e produtores acompanham de perto o trabalho dos repórteres, observando a evolução das matérias e direcionando a possíveis alterações da pauta. Novas demandas podem surgir, principalmente porque nessa hora já existe o espelho da edição. O repórter pode ser 
demandado a escrever novas matérias, principalmente influenciado pela evolução dos acessos das matérias no portal. É comum observar os produtores ou editores pedindo para atualizar produtos jornalísticos que estão com muito acesso na rede. Quando não são atualizados, suítes sobre o tema são solicitadas.

É interessante notar que um maior número de profissionais começa a se mobilizar para fechar o impresso. É no começo da tarde que é checada a evolução da matéria que é aposta de capa. Como os conteúdos são produzidos para múltiplos suportes, fotos precisam ser feitas com uma variedade grande para poderem ser aproveitadas em todos eles. As matérias de capa possuem exclusividade com as imagens.

Às $17 \mathrm{~h}$, aproximadamente, começa a terceira reunião de pauta formal. Ela tem a função de decidir quais matérias serão manchete no jornal impresso. Também cumpre o papel de aprovar e complementar quais temas serão tratados ao longo do dia e começa a delinear os do dia seguinte. Os repórteres que ficam de plantão na madrugada são orientados a partir dessa reunião. A reunião também se inicia com a observação das métricas, inclusive as de outros integrantes do grupo $\mathrm{RBS}^{70}$. Os dados são enviados a todos os editores. Matérias que estão rendendo em outros canais poderão virar matérias no online ou no impresso.

É comum, em todas as reuniões, os editores fazerem comparações dos acessos com a semana anterior - isso é feito na reunião da manhã também, como observamos. Com essa comparação, eles acabam analisando se determinados temas poderiam ser elencados na pauta da semana. A ideia é deixar de fazer esses comparativos semanalmente e começar a fazer por horários diários. A reunião das $17 \mathrm{~h}$ tenta ser um balizador do dia seguinte, como destaca $\mathrm{o}$ editor 3 (2016). "É esse motor-contínuo, desse motor-contínuo sai uma hierarquia do dia, que é referendada ou mudada na reunião de pauta. E ainda assim essa hierarquia da reunião de pauta pode mudar a qualquer momento se fatos novos acontecerem.”

Em um esforço nosso de tentar sistematizar a construção da informação do fluxo contínuo do Zero Hora, como pode ser visto no Gráfico 9, diríamos que a informação surge de ideias dos mais variados locais e de fontes ativas ou reativas. Elas são transformadas em pauta pelos membros da redação, repórteres, editores e produtores. Essas propostas são apresentadas na reunião de pauta que pode ser aprovada da forma que chega ou ser remodelada. Podem também ser rejeitadas, o que não presenciamos durantes nossos dias de observação. Quando aprovado o conteúdo, ele é passado aos repórteres para trabalha-lo. Eles vão apurar a pauta, alterar ou continuar com a angulação proposta e entrevistar fontes. Concomitante a isso, uma

\footnotetext{
${ }^{70}$ Fazem parte do grupo Zero Hora, Rádio Gaúcha, Pioneiro, ClicRBS, Diário de Santa Catarina, RBS TV, Rádio Gaúcha, Rede Atlântida, Ipanema FM, Rádio Farroupilha, CBN, CBN Diário, AM 1120.
} 
equipe de vídeo-repórter também pode produzir algum material, e a Arte pode elaborar alguma peça para complementar o conteúdo.

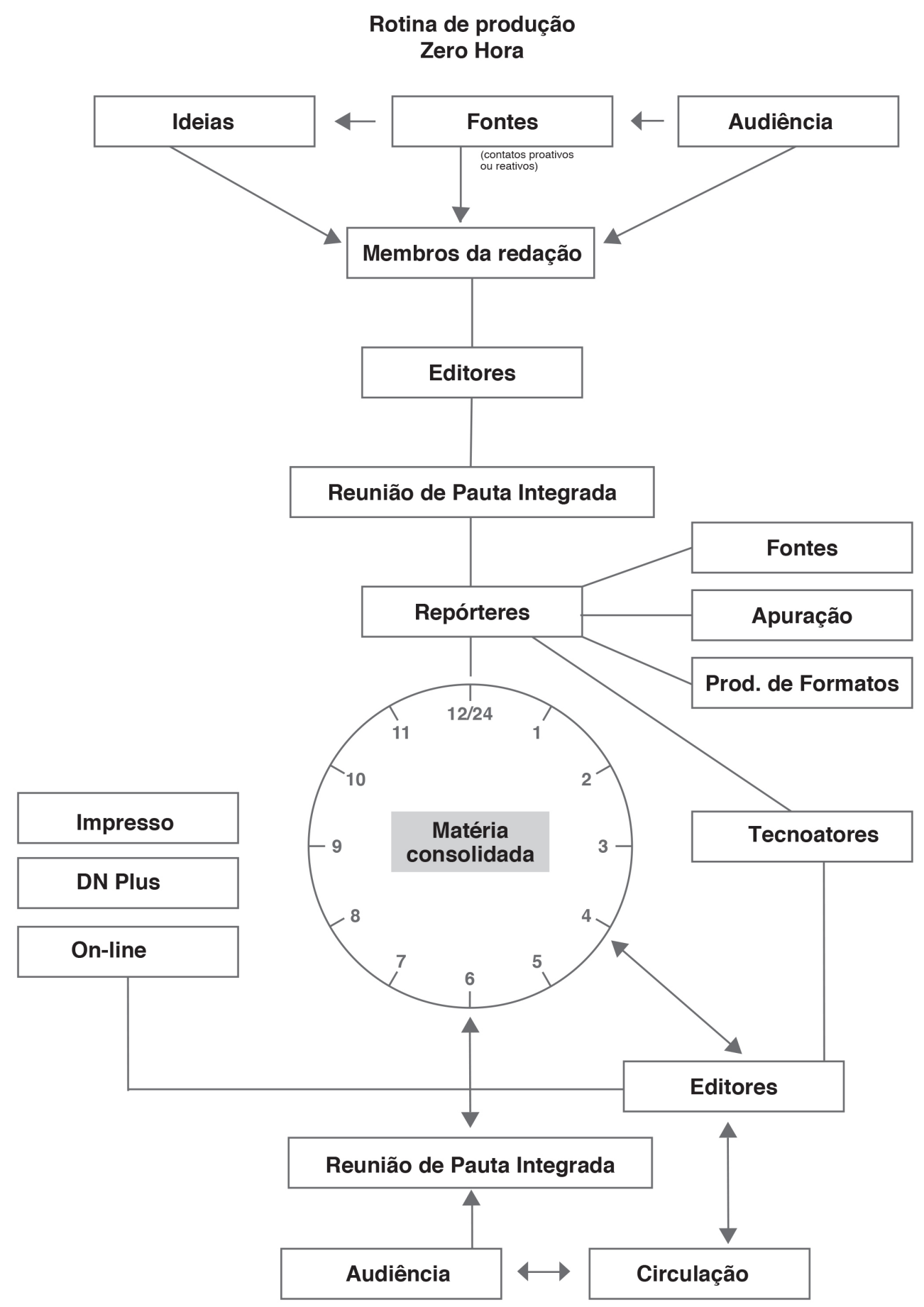

GRÁFICO 11 - Fluxo de produção circular do Zero Hora (produção nossa).

O fluxo de produção é ininterrupto por causa da jornada do leitor, que precisa ter informações em horários diferentes. Quando individualmente um repórter finaliza seu trabalho, ele passa o texto para um editor, que o revisa, e pode fazer novas considerações a serem trabalhadas, ou simplesmente libera o conteúdo para publicação, que pode ser para o 
online ou impresso, ou mesmo para os dois. Os dispositivos móveis também poderão usá-lo. Somente capas do impresso são negociadas com os outros suportes. Diariamente o impresso precisa de uma manchete mais consistente.

\subsection{DIÁRIO DO NORDESTE: A PAUTA E OS PROCESSOS PRODUTIVOS}

A redação do jornal Diário do Nordeste não funciona em fluxo contínuo, mas está integrada, isto é, funcionam num mesmo espaço o jornal impresso, o on-line e o Diário do Nordeste Plus ${ }^{71}$, produto que era específico para tablets até outubro de 2015. Não há plantonistas que cobrem o período noturno. De acordo com o secretário de redação (2016), não há demanda de audiência para esse horário. A redação possui estações de trabalho, que são divididas por editorias. Há uma mesa - que não é central - em que trabalham o editor executivo, com uma função próxima ao chefe de redação, e a diretora executiva digital. Contudo, o diretor-editor fica em uma sala separada da redação. É nítido que no $D N$ há uma centralização maior nas decisões de escolha e publicação de conteúdos. Não somente pelo formato da redação, mas pelo que a observação possibilitou notar. Os jornais, impresso e online, têm as mesmas editorias: Cidades, Política, Negócios, Jogada, Entretenimento, TVDN.

A primeira reunião pauta do dia é integrada e acontece aproximadamente às 10 horas da manhã. Trata-se de uma reunião integrada. Como não foi chancelada nossa participação da reunião, acabamos colhendo algumas informações por meio de entrevistas. Para o diretoreditor (2016), “a reunião é importante porque é nela que as pautas serão discutidas e melhor elaboradas. A pauta precisa de certo modo ser avaliada entre as áreas. [...]. Porque ali se faz uma discussão com uma visão de fora da editoria."

Participam da reunião todos os editores do jornal, além de jornalistas, designers e um representante da TI. Para o editor-diretor, a chegada de novos atores no processo de produção da notícia alterou o processo de produção da informação. "Esses colaboradores têm sido fundamentais para o jornalismo hoje em dia. Levando o próprio jornalista a pensar a maneira que se faz o jornalismo. E isso está se tornando algo interativo, que vai e vem”. Ele acredita que seja difícil trabalhar numa redação sem o conhecimento do designer, já que eles ajudam a

\footnotetext{
${ }^{71}$ Mais na frente, no tópico 5.5.1, explicaremos o funcionamento do Plus. Sua equipe produz conteúdo também para o caderno de tecnologia (impresso) do Diário do Nordeste.
} 
compor o produto jornalístico. "Quanto melhor você organiza o conteúdo, mais leitores você atrai e o mantém concentrado no conteúdo que está sendo apresentado."

Segundo o editor-executivo (2016), existe alguma tensão nesse diálogo, mormente por uma questão cultural. "Muitos dos profissionais que estão dentro de uma redação vêm de uma cultura em que a escrita era muito forte. É difícil romper isso.” O diretor-executivo (2016) explica que muitas vezes a redação deixa de produzir um conteúdo por esbarrar no fluxo de arte ou programação. Os profissionais que não são jornalistas conseguem dialogar com mais facilidade com os jornalistas. Isso vai acontecer também de forma inversa: jornalistas que trabalham com TI e design há mais tempo têm mais facilidade de pensar o conteúdo para ser desenvolvido por esses profissionais. Ao chegar na etapa de edição, o diretor-executivo (2016) admite que ainda há a possibilidade de alteração da pauta. "A pauta é o começo de tudo e por isso cabe à redação promover uma discussão do que se deve fazer. Para que, quando o repórter vá para apuração, ele já tenha em mente o que deve fazer”.

O diretor-executivo (2016) acredita que a integração da redação alterou drasticamente o trabalho dos profissionais. "Porque nós viemos de uma geração onde a internet era uma coisa e redação era outra. Então quem trabalhava em uma redação de jornal presenciou uma transformação em seu ambiente de trabalho." O profissional revela que, antes, o impresso era pensado em primeiro lugar, depois a internet. A integração alterou toda a lógica de trabalho. "E não tem como ser de outra forma, a internet é assim. Mais rápida, mais hardnews." O diretor-executivo (2016) acredita que os leitores de internet estão sempre atrás de conteúdo da maneira veloz: "Chamamos de geração F5", diz, comparando com as corridas de automóvel. Ele destaca que as plataformas permitiram pensar o conteúdo de outras formas, porque possuem mais recursos para se contar uma história.

$\mathrm{Na}$ reunião, os participantes usam métricas para examinar o trabalho publicado. De acordo com o diretor-editor (2016), métricas têm influenciado na produção e na edição do conteúdo. Na redação do $D N$ existe um cargo chamado de diretora executiva digital. Entre as funções que ela desempenha, está o acompanhamento das métricas. Duas ferramentas são utilizadas para o acompanhamento das métricas: o ComScore e o Google Analytics. A primeira, ComScore, permite aos jornalistas observarem os números das matérias publicadas, bem como os do concorrente. É um software bastante usado em redações do mundo inteiro. $\mathrm{O}$ mesmo acontece com o Google Analytics, que é utilizado para saber o posicionamento no mercado. Segundo a diretora (2016), esse não é levado tanto em conta para o direcionamento da linha editorial do jornal: "Nos ajuda, dá uma direção para as áreas, quando e como crescer determinado conteúdo, o que influencia diretamente a web. O que nos chama mais a atenção 
são as visitas quantitativas", que são os números totais de acesso ao portal. A editora explica que existe uma média de leitura para cada usuário, que é de 7,5 matérias.

No final do dia, a diretora executiva digital apresenta um relatório para a produção. Há uma tentativa, a partir desses dados, de apresentar crescimento. Ela diz que trabalha com um ciclo de seis meses, por conta da sazonalidade dos fatos. Essas informações são fornecidas por dia e por semana. Porém, há uma certa ponderação por alguns membros da redação: "Com certeza, até porque a gente sabe que a audiência e os números mostram alguma coisa. Tem que saber decodificá-los", explica o editor-executivo (2016). O jornalista acredita que a redação não deve trabalhar só em função dos números, contudo, eles são extremamente importantes dentro de uma redação, principalmente por se tratar de uma percepção instantânea. 


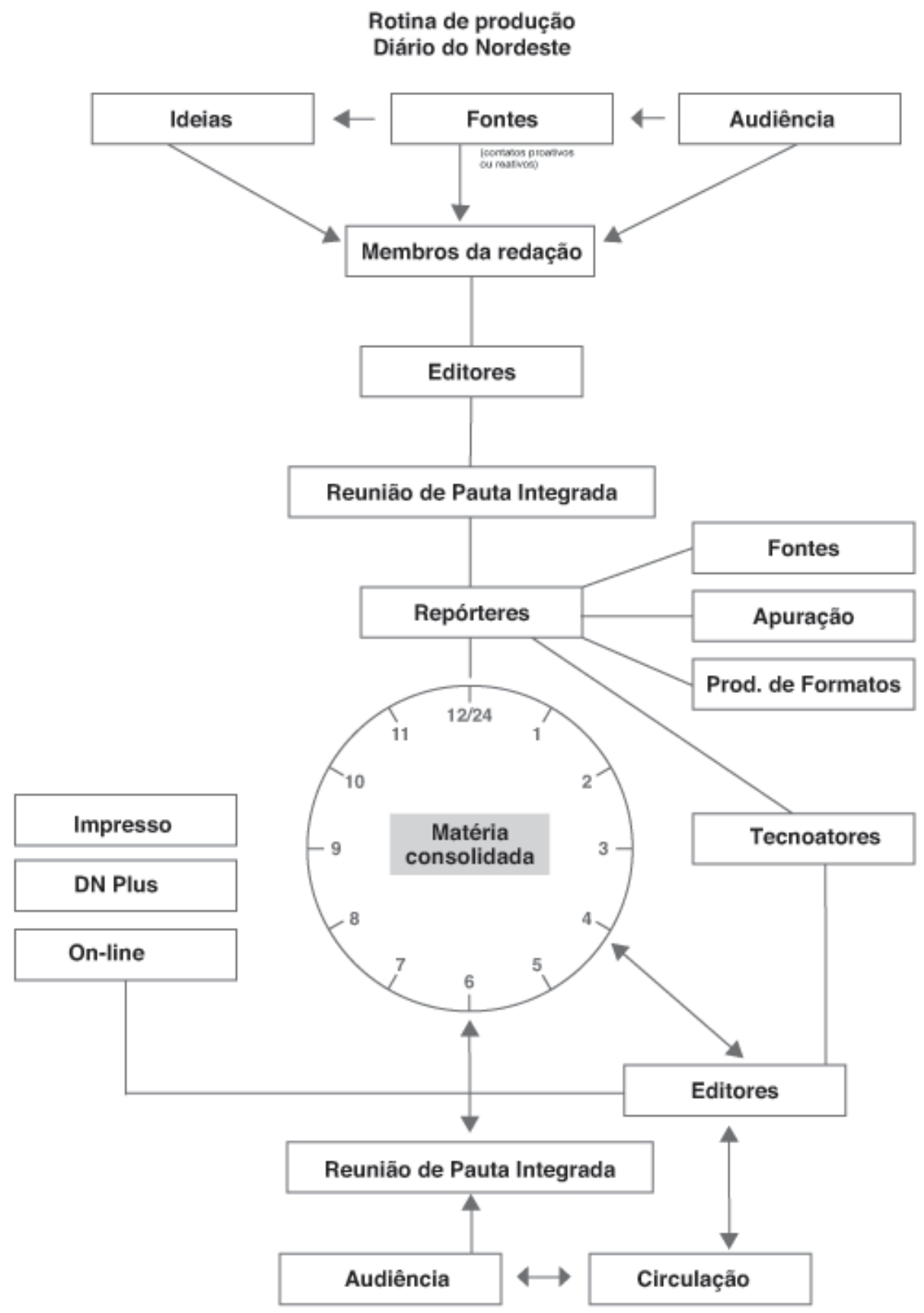

GRÁFICO 12 - Fluxo de produção circular do Diário do Nordeste (produção nossa).

As rotinas produtivas na redação integrada do Diário do Nordeste poderiam ser esquematizados como no Gráfico 12. Nele, vê-se que as sugestões de pautas surgem das fontes, sejam elas ativas ou passivas, da audiência, que tem tencionado e resinificado fatos, e das ideias, que surgem da observação direta do dia-a-dia, de conversas informais e dos mais variados espaços. Essas sugestões podem ser feitas por qualquer membro da redação. Como trata-se de um jornal com redação integrada, acontece às $10 \mathrm{~h}$ uma reunião de pauta integrada 
com os editores do jornal e alguns tecnoatores (CANAVILHAS et al, 2014). Apesar de ser uma reunião coletiva, é o diretor-editor que aprova o conteúdo final. A partir desse ponto as pautas são repassadas para os repórteres que passarão a atuar para produzir os conteúdos em parceria com outros profissionais (designers, programadores e repórteres fotográficos. É de responsabilidade dos editores aprovar a produção do conteúdo dos repórteres. Uma segunda reunião integrada acontece no final da tarde. Ela serve para avaliar a produção diária e para decidir o fechamento da edição do impresso.

\subsubsection{Diário do Nordeste Plus: de aplicativo a página web}

No Diário do Nordeste Plus - o informativo para tablets produzido diariamente por uma equipe de dois jornalistas e uma designer - todos os membros da equipe sugerem pautas, opinam e devem falar sobre as propostas feitas para o vespertino. A edição é publicada às $19 \mathrm{~h}$ das segundas-feiras. As pautas surgem do dia a dia das pessoas, de releases, fontes estabelecidas ou de sugestões dos leitores. É debatida nas reuniões a capacidade do conteúdo poder ser aproveitado em termos de interação e do emprego de recursos multimidiáticos. Os editores buscam refletir se o tema é realmente viável para o Plus. Sem esses elementos, certamente o conteúdo é derrubado na reunião. Para isso, a presença da designer é fundamental para propor dicas e apresentar as limitações e adequação da proposta.

A reunião de pauta acontecia todas as segundas-feiras, pela manhã, até novembro de 2015, quando o vespertino não fazia parte da integração da redação do grupo. Era uma reunião semanal para debater todas as edições, como era feita em $O$ Globo a Mais. A apresentação era feita de forma oral. A redação do DN Plus ficava em uma sala, ao lado da redação principal, local de produção do impresso e da versão para a web. Apesar da proximidade, não foi observado um fluxo de outros profissionais na sala para compartilhamento de informação. Não existia nessa época integração com a redação.

A edição era composta pela capa, uma página com um tutorial, uma galeria de fotografias com seis fotos, a seção Panorama, que é um resumo das notícias que saíram no dia no portal. Existia também uma matéria principal. Contudo, em eventos especiais, duas páginas podiam ser diagramadas, bem como era possível entrar mais uma matéria secundária, o roteiro cultural e o expediente. Além desses normais, existiam editorias flutuantes, chamadas de Especiais, como Novos Sons - enfocando bandas que estão se destacando no 
Ceará - ou sobre personalidades do estado, não necessariamente conhecidas. Trabalhavam na edição do vespertino, na época autóctone, um editor, uma vice-editora, que também atuava como repórter, uma repórter e duas designers.

Repórteres produziam conteúdos a partir de sua apuração. Apesar de existirem externas, muitas matérias e conteúdos eram produzidos a partir da redação. Essa produção se dava principalmente com a reportagem, que era semanal. Ao produzir conteúdo, todos levam em consideração as características dos tablets. De acordo com o editor 1 do Diário do Nordeste Plus (2016), é necessário produzir assuntos que permitam criar recursos de interação, possuir vídeos, fotos e texto. A ausência desses recursos pode atrapalhar um pouco a resolução da pauta. Por ser um dispositivo que possui alta resolução, o aplicativo passou por um processo de reformulação gráfica, para privilegiar a questão da imagem, então isso tem que ser analisado na hora da pauta, ter imagens de qualidade.

Não existia acompanhamento de métrica para escolher pauta. Os conteúdos propostos são, de preferência, atemporais, abrindo mão somente desse aspecto quando se trata de um evento de grande impacto, tanto nacional como local. As mídias sociais também são um canal de fonte para o Plus. Mas o editor 1 DNPlus alerta que nem tudo que está nas redes sociais vai para o Plus, principalmente porque os arquivos geralmente não possuem qualidade, mas podem gerar uma reportagem. Nesse caso o repórter deverá ir a campo apurar ou por telefone. Alguns arquivos são feitos pelos próprios repórteres, com telefones celulares.

A redação conta também com a TVDN para produzir vídeos e pequenos documentários. Todo o conteúdo é editado pela equipe da TV do Diário do Nordeste. As jornalistas editavam as matérias no Indesign, mas, apesar disso, duas designers eram as responsáveis pelo desenho e diagramação da página. Foi possível constatar que alguns repórteres utilizam o Google Docs para escrever matérias. Segundo o editor 1 do Diário do Nordeste (2015), é vantajoso porque a equipe trabalha online e o conteúdo pode ser acessado por todos.

As matérias do Plus vão para o impresso e para o online. Segundo o editor 1, não há matérias dos outros suportes publicadas por eles. Ele explica ser raro isso acontecer. "[...]A não ser que tenha um material muito especial lá, mas muito especial mesmo, que não haja como ir todo lá; eles negociam para a gente aproveitar esse resto de conteúdo." Não existia planejamento prévio à arquitetura da informação ao pensar nas matérias. São os repórteres, junto com as designers, que pensam como é que vão organizar os conteúdos. É interessante notar que, ao tocar assunto, os jornalistas, apesar de não deixarem explicito, não tinham domínio do que se tratava a arquitetura da informação. Ao construir um hipertexto, o editor 1 
diz que é pensado o texto principal, e depois partículas de informações que são importantes. Depende do tipo de matéria.

Existe sempre uma preocupação com a interatividade e com o uso máximo de recursos do tablet. Há uma tentativa, por parte dos repórteres, de produzir textos com tamanho de uma lauda e meia, espaçamento 1,5. Nem sempre isso é alcançado e o texto precisa ser cortado. Essa orientação é para textos para serem publicados no dia. O restante são colunas.

Os formatos midiáticos são escolhidos por critérios próprios dos repórteres. "O áudio, acho que é raríssimo a gente usar, só quando é música e a banda não tem um vídeo legal. O vídeo é bem mais usado; é mais interessante, a pessoa vê, tem o visual da coisa, além de ouvir", explica o editor 1 do DNPlus. Isso dependerá do conteúdo, então a escolha será pautada pela percepção de quem o produz. Também não há um modelo de produção textual. A orientação está mais próxima ao modelo do online. O seu fechamento acontecia às 19h, com sua imediata publicação.

O editor compre como função aprovar pautas, revisar e editar os textos, acompanhar o trabalho dos repórteres, conversar com a diagramação, tentar resolver problemas administrativos, reservar carro e fotógrafo.

Para trabalhar no DN Plus é necessário ter um bom texto e entender minimamente de diagramação. No entanto, só texto não é o bastante, um repórter precisa ser multitarefa e generalista - escrever sobre variados temas. $O$ jornalista precisa desenvolver sua pauta, pensar na foto, no vídeo, tem que ter uma ideia de como vai ser desenhado o texto, deve ter capacidade para levantar em assuntos relevantes para a edição. A ausência de preconceito é citada como um dos elementos importantes para exercer a função.

\subsubsection{Reformulação do Plus}

No final de 2015, depois de outubro, a concepção do Diário do Nordeste Plus muda completamente. De aplicativo torna-se uma página na web, em formato HTML 5, ou seja, uma página responsiva. O editor do DNPlus (2016) diz que os motivos principais para a mudança foram a alteração no mercado, como constatado no nosso capítulo III. A periodicidade também foi alterada, passou a ser semanal, com publicação às segundas. A editora executiva digital (2016) explica que a mudança do Plus aconteceu principalmente por 
causa do usuário. "Caiu o número de usuários de tablets, a gente viu que o cenário que tínhamos no [telefone] móvel era muito promissor."

Com a reforma no Plus, a versão para telefones móveis deixou de ter colunas e outros formatos, como galerias de imagens, restando somente uma reportagem multimídia em longform $^{72}$. O Diário do Nordeste Plus também deixou de ser direcionado aos tablets para atender um mercado em expansão dos telefones móveis. Não existe mais a preocupação com a leitura do final do dia ou com a avaliação do dia por meio de notícias, como acontecia na versão anterior, que deu origem ao aplicativo.

Como o novo direcionamento está para telefones móveis, há também um cuidado com o tamanho das imagens e vídeos usados nas reportagens. "Mas percebemos que mais da metade dos usuários do Plus acessa a partir de conexões fixas. Temos o cuidado de mandar pacotes pequenos pensando em pessoas que acessam a partir de redes móveis", explica o editor 1(2016) do DNPlus. O novo fluxo de produção de matérias no DN Plus ficou mais parecido com o das redações tradicionais, que pode ser visualizado no Gráfico 13 a seguir:

\footnotetext{
${ }^{72}$ Em uma tradução literal seria chamado de reportagem em formato longo, verticalizada.
} 
Rotina de produção

Diário do Nordeste Plus
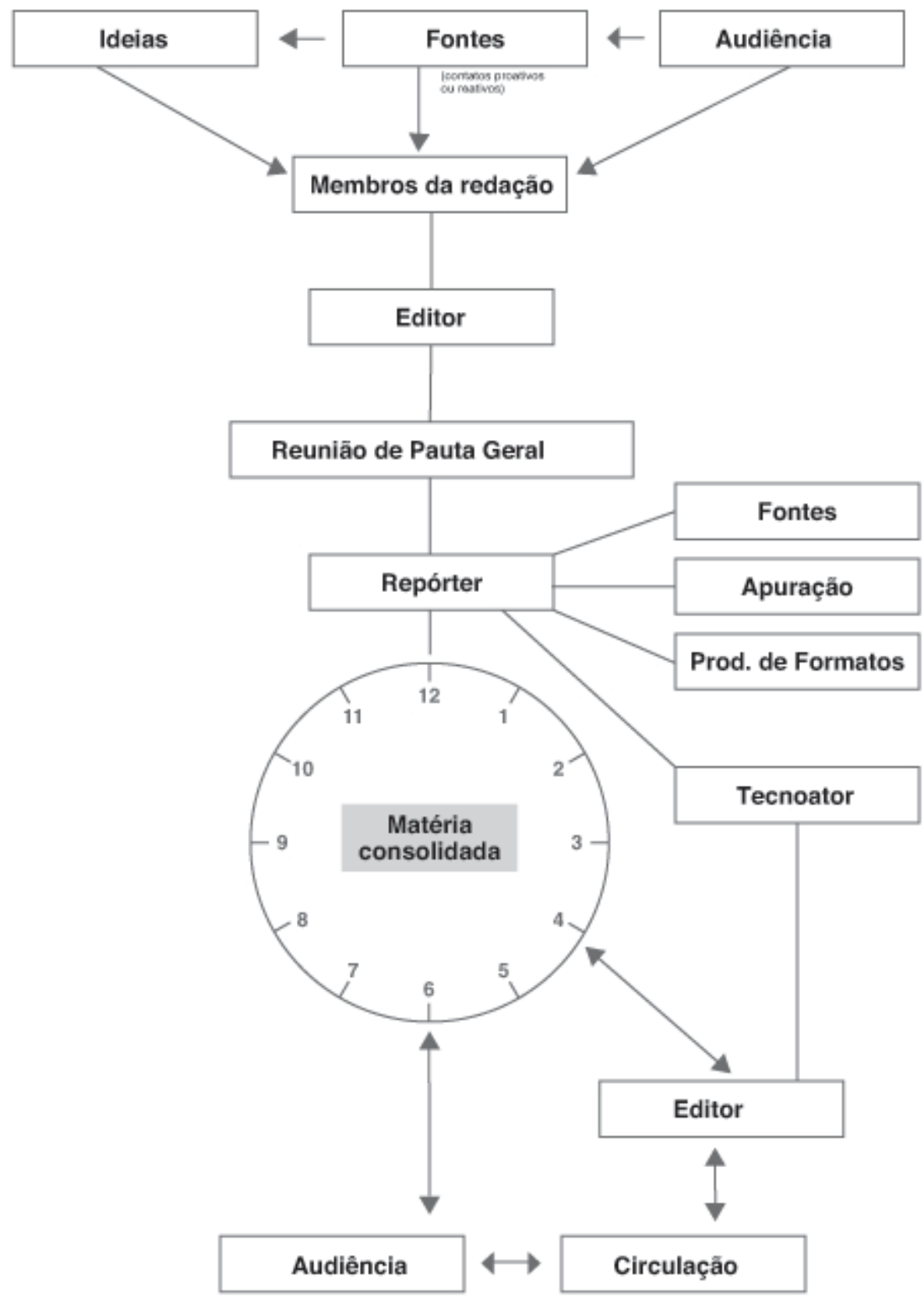

GRÁFICO 13 - Fluxo de produção circular do Diário do Nordeste Plus (produção nossa).

As reuniões de pauta continuam a acontecer semanalmente. Participam o editor, uma repórter, uma pessoa da arte e um estagiário, que atualmente são responsáveis por criar conteúdo no Plus. Eles fazem parte da redação integrada do Diário do Nordeste, e assim, 
acumulam outras funções. Os profissionais produzem semanalmente também o caderno de Tecnologia do impresso e diariamente alimentam a página web.

Para que uma pauta seja aprovada, segundo o editor do Plus, é preciso que os assuntos sejam relevantes e que os temas sejam duráveis. "Tem que ter uma história interessante para ser contada. Tentamos colocar temas que sejam legais para discussão. A questão é pensar em uma matéria que dure por muito mais tempo. Ela vai para o ar hoje, porém, é um assunto que vai ter uma repercussão de mais ou menos um mês."

Outro aspecto fundamental, que não vai se diferenciar do modelo anterior, é saber como enriquecer o conteúdo. Para o editor do Plus, a pauta pode restringir ou não o trabalho do repórter. Ela ajuda a ter um objetivo, delimitando a abrangência do assunto. As características do suporte também podem inviabilizar uma pauta. $\mathrm{O}$ editor 1 diz que, ao sair para produzir o conteúdo, o repórter pode descobrir que o assunto não vai render foto nem vídeo: "Daí já cai a pauta. Não dá pra ser só o texto". Outra possibilidade é que alguns assuntos não são aprovados na reunião de pauta, seja por tratar temas sensíveis à linha editorial ao jornal, seja pelo próprio assunto.

Angular no Plus é escolher a melhor abordagem do assunto, bem como delimitar o assunto. O que leva à angulação ou enfoque é justamente a ausência de capacidade de falar de tudo. Como exemplo, ele diz que mesmo que se escolham três aspectos diferentes de um tema, o repórter não terá condições de falar de tudo. Importante é ter um objetivo definido.

As pautas costumam surgir de locais variados. De acordo com o editor 1 (2016), elas nascem de conversas, experiência de quem propõe e até de mídias sociais. Ele explica que os locais são variados. E para isso todos podem contribuir, inclusive os designers que participam da reunião. As contribuições são diversas, alertando para possíveis falhas que possam ocorrer na pauta ou até mesmo novas ideias para deixar a proposta mais interessante.

A relação entre jornalistas e outros atores na redação costuma ser tranquila. Essa tranquilidade parece advir do fato de que a designer convive no ambiente da redação há bastante tempo. Isso acaba diminuindo a tensão. A tensão maior está na área de desenvolvimento de tecnologia. No processo de construção de produtos jornalísticos acabam acontecendo alterações no produto solicitado. Isso provoca uma atenção redobrada por parte dos editores ao receber os produtos.

É interessante notar também que há uma estrutura muito verticalizada na redação do Diário do Nordeste. Como exemplo, no DNPlus, ao ser perguntando se repórter pode alterar a pauta, o editor é categórico: "Ele só pode alterar durante a reunião ou na hora da apuração". Contudo, isso pouco acontece na redação. O processo de edição não altera a pauta, segundo o 
editor 1 (2016): “Às vezes, quando o texto está finalizado e você vai editar, enxerga melhor a localização de cada peça. A pauta não se altera, mas a forma com que o conteúdo vai ser visto pelo leitor, sim."

No novo Diário do Nordeste Plus, as mídias sociais têm servido para compartilhar a pauta com a audiência. "[As mídias sociais] ajudam também para receber feedback dos leitores, uma crítica para o conteúdo. (...) Por ser direcionado a um determinado público depois do material distribuído, nós fazemos uma medição com relação à aceitação daquele conteúdo."

\subsection{OS PORTÕES NOS MEIOS DE COMUNICAÇÃO E A IMPORTÂNCIA DA PAUTA}

Observar três meios de comunicação nos oportunizou fazer descobertas interessantes em relação ao processo de seleção e passagem pelos portões da notícia. São descobertas relacionadas à teoria do gatekeeping e das rotinas de produção. Todos os membros da redação funcionam como portões dos grupos de comunicação: repórteres, editores, produtores, estagiários, designers e programadores são algumas funções que podem sugerir pauta. Isso funciona tanto no aplicativo $O$ Globo a Mais, como nas redações integradas do Zero Hora e do Diário do Nordeste. Apenas O Globo a Mais, enquanto durou a experiência, não fez parte da redação integrada do jornal O Globo. Tivemos a oportunidade de observar o fluxo do Diário do Nordeste Plus antes e depois da integração com a redação e, portanto, pudemos registrar as mudanças no cenário, na cultura organizacional e nos produtos.

A passagem da informação estará sempre condicionada a diversos fatores. Primeiro diríamos que a qualidade da informação e a capacidade de análise do profissional são fundamentais para cruzar o primeiro portão. Releases, observação diária, mídias sociais, conversas informais, leituras, acompanhamento da concorrência e audiência são fontes para essa cruzada. A informação, muitas vezes, chega sem tratamento jornalístico e, com isso, terá mais dificuldades de cruzar o portão para virar notícia. Os fatos precisarão reunir um maior número de elementos (valores-notícia, disponibilidade e interesse) para seguir adiante.

É nesse contexto que algo se mostrou fundamental: a capacidade de angulação da informação. O conteúdo pode chegar angulado de acordo com os interesses do profissional ou precisará ganhar novos contornos para se viabilizar. Porém, uma boa qualidade da informação, valores-notícia, condições técnicas e um dia propício são algumas condições para 
essa aceitação. Chamar a atenção do repórter para a construção da pauta é fundamental para que o editor aceite a sugestão e leve ao segundo nível. Nesse aspecto, os cinco níveis propostos por Shoemaker e Vos $(2011)^{73}$ estarão em funcionamento para que essa avaliação seja feita.

Veremos, no Gráfico 14, como acontece a seleção de temas no processo da pauta, de acordo com os níveis 1) individual; 2) coletivo; e 3) institucional.

\footnotetext{
${ }^{73}$ Explicamos esses pontos no capítulo II.
} 

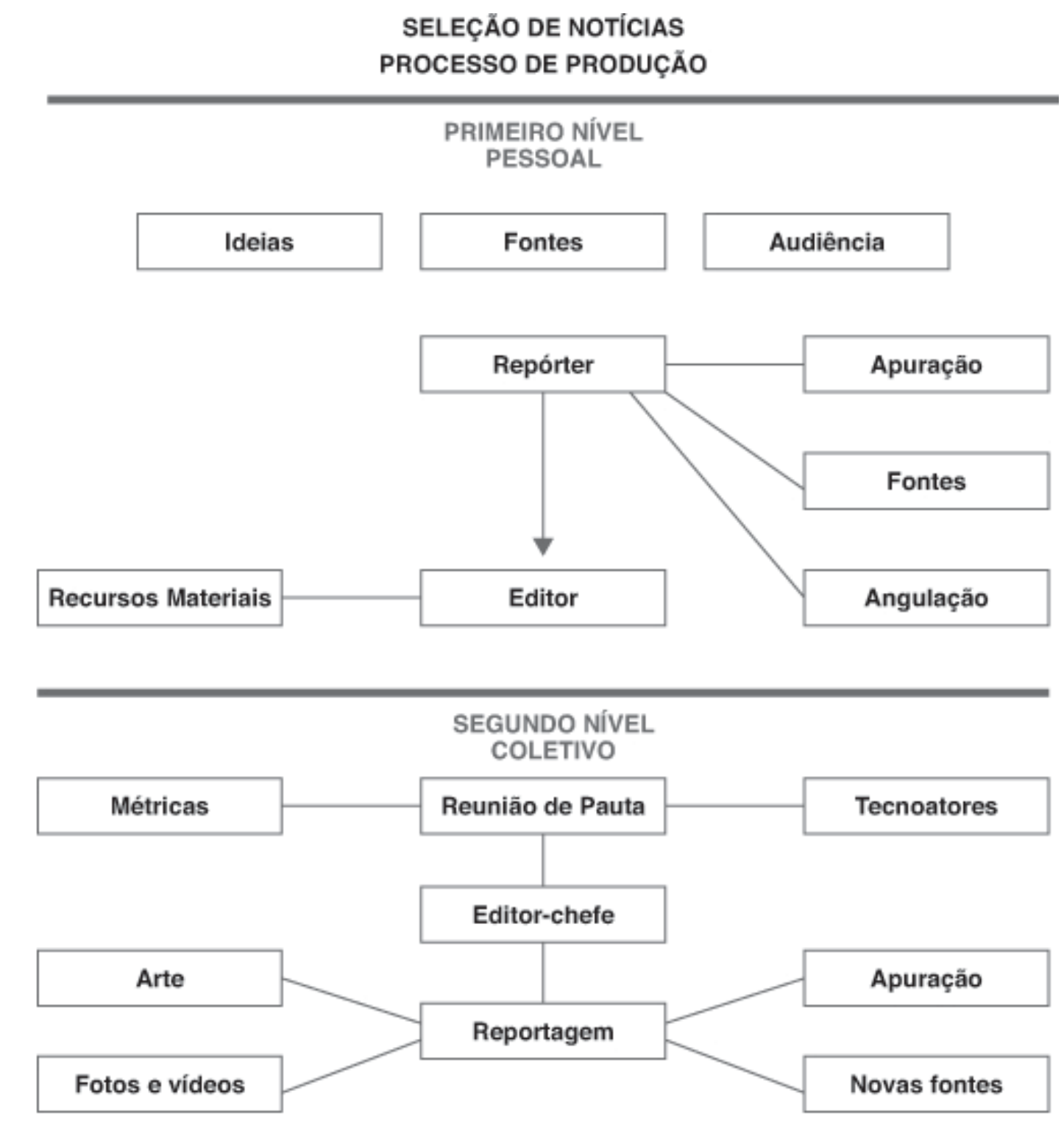

TERCEIRO NÍVEL

INSTITUCIONAL

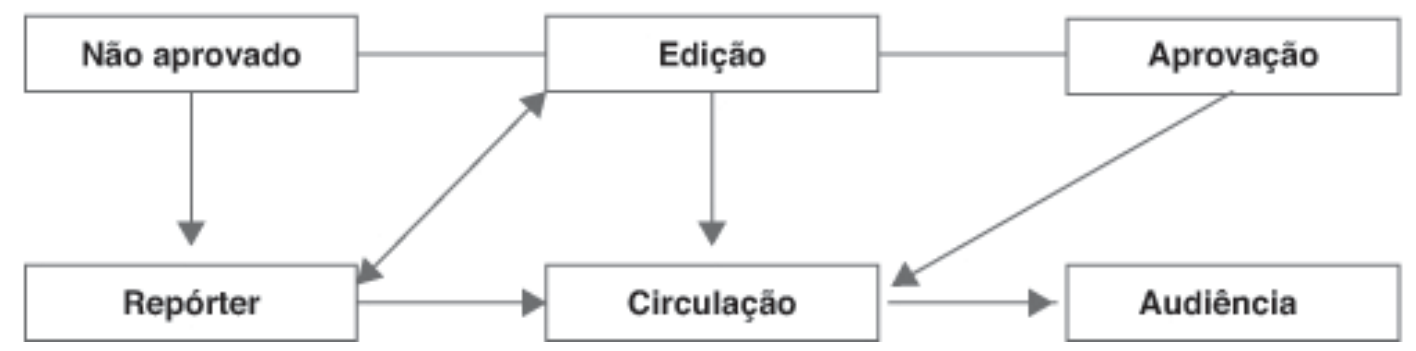

GRÁFICO 14 - Três níveis de seleção da informação no processo de produção: pessoal, organizacional e institucional (produção nossa).

Primeiro, o nível pessoal, individual, faz com que, a partir de sua compreensão de mundo, o profissional aponte determinadas escolhas que lhe pareçam mais interessantes que 
outras. Neste aspecto, parece que, para os repórteres e produtores (que são pauteiros), os ideais românticos do jornalismo são mais pulsantes. Temas que possuam maior apelo social, coletivo, certamente ganharão destaque. Seu conhecimento de mundo também condicionará de alguma forma o aproveitamento da informação.

Segundo, o coletivo estão introjetadas também nos profissionais. Para que o trabalho aconteça, ele precisa ser feito a partir de normas estabelecidas. Com isso, todos procuram observar elementos diários no assunto e, a partir disso, propor a pauta de acordo com as convenções. O profissional da comunicação só elege uma informação que tem um potencial de receber tratamento jornalístico. Como todos os dias são apresentadas do mesmo jeito as propostas, dominar essas rotinas é garantia de que a informação cruzará o portão, será selecionada, ou seja, ele estará fazendo o trabalho corretamente. Isso vai acontecer inclusive com os profissionais que não possuem formação jornalística. Sem dominar esses códigos, sem obedecer ao habitus jornalístico (BOURDIEU, 2002), o profissional dificilmente conseguirá propor algo que tenha capacidade de receber tratamento jornalístico.

O terceiro nível, institucional, como a análise de variáveis como parâmetros de participação de propriedade na mídia, fica mais visível em locais com hierarquias mais verticalizadas, como no Diário do Nordeste. Nesses locais é perceptível que a autoridade dos cargos com maior capital simbólico seja mais valorizada. Há uma preocupação com questões editoriais que estão mais atreladas à propriedade da mídia. Esse nível tende a funcionar mais nas reuniões de pauta, quando o editor-chefe participar do processo de aprovação. Nota-se que a proximidade com repórteres dificulta a rejeição de pautas. Alguns fatores poderiam ser elencados como motivos: o primeiro deles é o conhecimento apurado dos gostos do editor; um segundo, o possível desenvolvimento de afinidades. Isso não quer dizer que este nível não esteja introjetado nos profissionais que controlam esse primeiro fluxo. É justamente na reunião de editores que o filtro funcionará melhor.

A proximidade dos editores com os repórteres pode ter relação também com o fato de que o reconhecimento, entre os colegas de profissão, ao propor a pauta, é fundamental para que ela siga adiante. É nítido que determinados profissionais com maior capital simbólico provocam um maior encantamento quando falam - geralmente os editores mais antigos. $\mathrm{O}$ que foi percebido em alguns momentos é que o tempo de profissão e uma especialização sobre o tema darão maior autoridade ao profissional. O que estamos dizendo que é que, quanto maior o capital simbólico do profissional, mais fácil será que a informação cruze o portão, ou seja, o repórter com maior prestígio na redação emplacará pautas com mais facilidade. 
Neste ponto estão as influências do governo e grupos de interesse, também é observado na escolha do tema. Certamente esse aspecto influenciará o profissional de comunicação na sua escolha para ter mais segurança. Fontes estáveis fazem parte do ritual estratégico dos jornalistas e garantem o melhor funcionamento das rotinas. Isso é observado nos press-releases diários, distribuídos pelas assessorias de comunicação das empresas públicas e privadas, que são consultados para a produção de pautas. Aqui há também um elemento central nas redações: a capacidade de produção. Nas redações integradas, em que o fluxo de produção é maior, parece que aumenta a dependência desse tipo de fonte. Por fim, nesse nível do sistema social, a análise de variáveis como ideologia e cultura também provocará reações no profissional. Ele tenderá a optar por informações que possuam maior aceitação e que estejam mais em voga.

No âmbito das práticas, no primeiro nível do portão há apuração que precisa ser feita. Nem todos os profissionais que propõem boas ideias fazem boa apuração. Para que seja apurada, e assim cruzar o primeiro portão, a informação precisa ser trabalhada. Na maioria dos casos, a indicação de fonte para o desenvolvimento do texto aí acontece. O que estamos propondo nessa etapa do portão é que três pontos são fundamentais para que ela avance e ultrapasse um novo portão: angulação, apuração e fontes.

Em redações integradas, em que o prazo é mais curto para execução do trabalho, a informação só passa pelo portão quando estiver amadurecida. Em periódicos com deadlines mais longos, como o Diário do Nordeste Plus e o antigo O Globo a Mais, pautas tendem a chegar menos desenvolvidas, com formato de tema. Isso não quer dizer que não exigirão apuração, mas com prazos mais dilatados há uma flexibilização maior dos portões, bem como na forma a que chegará. Isso acontece na produção de todos os formatos.

O segundo portão a se cruzar é o da reunião de pauta geral e/ou integrada - vai depender sempre do formato da redação. Caso o formato seja amplo, é o repórter ou um nãojornalista que defende ideia. Como dissemos, quanto mais capital simbólico esse profissional possuir, mais fácil será sua aprovação. E nesse caso identificamos dois fatores: conhecimento e reputação como profissional.

Este é um portão decisório porque recebe o aval do maior gatekeeper, que é o editorgeral - ou função equivalente. É a partir dele que o repórter sai para campo e produz a informação. Os participantes da reunião de pauta com o editor-geral interferem na proposta e dão novas sugestões. É dele, auxiliado pelos editores, que parte a decisão final se o conteúdo será publicado ou não. Mais uma vez, todos os níveis propostos por Shoemaker e Vos (2011) entram em ação, só com uma visão mais coletiva e com profissionais de maior mando. 
Neste ponto, apenas a apuração do repórter altera o foco do trabalho. E, mesmo assim, as alterações precisam ser comunicadas aos editores, que acompanham de perto o trabalho do subordinado. Há elementos que podem interferir nesse processo de tratamento jornalístico: a) as fontes e b) na parte material, a qualidade dos conteúdos midiáticos produzidos. As fontes tensionam para que as versões que sejam do seu interesse ganhem visibilidade. Há também o processo de apuração, que é a checagem de dados e a busca por especialistas, personagens e dados documentais. Nesse processo, cabe ao jornalista observar quais informações são de maior relevância para sociedade. Está em funcionamento o processo de mediação ${ }^{74}$.

Finalizado o trabalho de apuração, entram em ação os editores. A eles chegará o conteúdo para sua possível aprovação. Trata-se de um novo portão que pode re-mediar a pauta e os conteúdos que cruzam o último portão. A edição pode mudar rumos, caso seja necessário, ou seja, o repórter pode ser demandado a fazer uma nova alteração. Inconsistência na apuração, qualidade do conteúdo, títulos, legendas e construção de narrativa são observados nessa etapa.

Em suma, o que estamos propondo é que, para a informação chegar à audiência, ela precisa cruzar três portões, que envolvem todo o processo de produção jornalística. Há um aspecto, dessa vez específico para os dispositivos digitais, de que o conteúdo ao chegar não pode voltar a ser alterado.

O elemento que não costuma aparecer nos debates sobre gatekeeping é que ,dentro de um produto jornalístico, existem informações que interessam a variados grupos. Múltiplos são os envolvimentos por detrás de uma reportagem. Entendemos que todo o processo de produção jornalística acrescenta ou diminui dados de diferentes fontes. E, quando uma proposta cruza o portão, são múltiplas as motivações. Todos buscam fazer com que a informação cruze os portões da forma que lhes interessa.

\footnotetext{
${ }^{74}$ Nosso trabalho não tem foco nesse debate.
} 


\section{CONSIDERAÇÕES FINAIS}

A ideia norteadora deste trabalho surgiu de uma revisão bibliográfica e da constatação empírica deste pesquisador, que é jornalista: as rotinas jornalísticas têm passado por transformações, principalmente no âmbito do jornalismo digital. A partir desse ponto, nasce a proposta desta pesquisa - vinculada ao projeto do Laboratório de experimentação em linguagens digitais para dispositivos móveis e desenvolvimento de novos produtos jornalísticos para tablets e smartphones (Labdim), coordenado pela professora doutora Thais de Mendonça Jorge -, que foi se aperfeiçoando ao longo do curso de doutorado.

A qualificação representou um divisor de águas para esta tese, principalmente pela perspectiva de ampliar a proposta inicial, que era estudar e refletir sobre as rotinas produtivas para tablets. Esta primeira avaliação nos fez buscar um aspecto que nos chamaria mais atenção durante nossa observação empírica na redação de $O$ Globo A Mais: a pauta. Afunilamos, assim, nossa busca por questões que tivessem impacto no habitus jornalístico e pudessem ser problematizadas ao longo desta investigação acadêmica.

A pesquisa nasce também de uma dificuldade como docente e da constatação de que eram reduzidos os trabalhos acadêmicos que sistematizavam e refletiam sobre o processo de construção da pauta, principalmente quando o assunto está relacionado aos tablets no âmbito da convergência jornalística. Empreendemos em 2015, nos programas de pós-graduação em comunicação filiados à Compós, uma busca sobre o tema. O resultado encontrado mostra que somente uma tese (LUZ, 2005a) e uma dissertação (OBLIZINER, 1997) tratavam sobre o tema.

É a partir de uma revisão de literatura e da problematização da pesquisa, que nos perguntamos: a pauta ainda é um documento importante nas rotinas produtivas de uma redação convergente, em especial na redação de informativos para tablets? Partimos da hipótese (1) de que a inserção das versões para tablets nas redações proporciona transformações na produção da pauta, com repercussão nos processos de produção, edição e distribuição dos conteúdos. Para responder às questões iniciais, esta tese tem como objetivo geral analisar e refletir sobre quais são e como os elementos que compõem a pauta de uma edição jornalística para tablets são transformados. Nosso corpus, composto pelos aplicativos O Globo A Mais, Zero Hora Noite e Diário do Nordeste Plus, possibilitou observar as mudanças e acrescentou novas reflexões ao trabalho. 
Dependendo da organização da redação, a produção de notícias numa redação integrada pode ser alterada complementarmente. Fica claro, como a bibliografia tem relatado, que as decisões empresariais, em termos de investimento, sejam eles humanos, sejam em tecnologias, influenciarão decisivamente no processo de produção. Cada redação (integrada) que faz uso de diversas versões de aplicativos, mostra um diferente tipo de organização no processo de produção.

O Globo A Mais, apesar de estar no mesmo prédio físico que o jornal impresso $\mathrm{O}$ Globo, possuía sua redação separada da lógica de produção dos outros meios. A influência direta disso é que existia um grupo de profissionais trabalhando exclusivamente para esse suporte. As pautas de conteúdo precisavam contemplar as características do meio para serem aprovadas. Atestamos que assuntos que não possuíam capacidade de ser enriquecidos com formatos variados não podiam virar pauta. Os temas eram aprovados nas reuniões de pauta geral, com periodicidade semanal, para que os conteúdos pudessem ser produzidos de forma mais elaborada. Tudo era pensado de maneira direcionada a uma plataforma e isso parece funcionar com mais efetividade quando olhamos (MARQUES, 2014a) para o produto final.

Isso implica que, além de pensar no conteúdo de forma diferenciada, o repórter precisa também saber organizá-lo, criar uma arquitetura da informação, pensar na dupla navegação e na tactilidade, bem antes de construir sua narrativa. Tudo isso é discutido e pensado durante a reunião de pauta. Não se trata de um empacotamento ou mesmo de uma reorganização do conteúdo que já tinha circulado em outros suportes.

Essas especificidades na produção de conteúdo para o suporte não foram identificadas no Zero Hora Noite. Apesar de possuir dois profissionais trabalhando exclusivamente na edição, todo o assunto que circulava no periódico já tinha sido produzido por outros jornalistas. Esses dois profissionais responsáveis pelo ZH Noite precisam somente selecionar e dar forma às matérias que circulariam na edição das 19h. Apesar de terem uma reunião de pauta para referendar os assuntos finais, principalmente o de capa, essa reunião não se mostrava muito eficaz em termos de pensar o conteúdo e sim de não existir colisões de temas entre os suportes, bem como de manter de alguma forma os controles editorias do Grupo.

A função da reunião de pauta aqui é organizacional, no sentido da empresa. A pauta, nessa instância, tem menor vulto porque a maioria dos processos produtivos, que são engrandecedores e caros à profissão, são anulados, ficando somente a tarefa de organização de conteúdo. Com essa observação, não estamos invalidando todo o trabalho feito na redação, mas tão somente percebendo a produção de temas que vão para um suporte específico. 
O Diário do Nordeste Plus é um misto dos dois outros suportes observados (O Globo A Mais e Zero Hora Noite). Trata-se de um aplicativo que é pensado e gerado dentro de uma redação convergente, mas que possui reuniões de pauta, com uma equipe reduzida de pessoas para trabalhar os temas. Diferente do ZH Noite, não há empacotamento da informação. Porém, os profissionais precisam também gerar assuntos que circularão na editoria de tecnologia dos outros suportes.

Nesse aspecto, há duas questões importantes: conteúdos são pensados para o suporte de forma quase exclusiva, já que possuem uma repórter, um editor e uma designer com a equipe da Tecnologia da Informação disponível para finalizar o produto e isso possibilita que algo mais elaborado seja feito. A segunda é que o número reduzido de mão-de-obra e a divisão do trabalho com outras coisas acabam demandando tempo para elaborar um material com melhor qualidade.

Com isso, percebemos que a pauta é fundamental no processo, já que propor um conteúdo que se adeque ao formato é condição central para que o assunto seja aprovado. As reuniões de pautas também mostram-se efetivas para debater, com um viés mais direcionado, sobre a audiência do suportes e suas potencialidades. É importante frisa que, no atual momento do DN Plus, somente uma reportagem semanal é feita. Esse fluxo tem acontecido agora, com a nova proposta do Plus.

Antes dessa mudança, podemos afirmar com muita tranquilidade que a forma de produção era muito parecida com o que era feito na edição do aplicativo carioca, O Globo A Mais. Primeiro pela equipe disponível para a produção. Como era um aplicativo com várias sessões e conteúdos gerados, esse tipo de organização demandava mais trabalho. Mais gente trabalhando também é sinônimo de um conteúdo mais plural, mais elaborado. Os dois momentos distintos observados no aplicativo reforçam a ideia que estamos defendendo aqui: a organização da redação e os recursos matérias disponíveis são fundamentais nas rotinas.

Com as observações acima, podemos afirmar que a reunião de pauta nesses aplicativos é um elemento central para pensar no conteúdo que será produzido. Sem debater aspectos que comporão a pauta não é possível aprovar os assuntos. As características do suporte influenciarão inclusive na angulação da matéria. Boas fotos, arquivos de alta qualidade e tema com capacidade de se transformar em interativo possuem um apelo maior nessas publicações. O que estamos querendo dizer é que a angulação do texto também perpassa pelas potencialidades do suporte.

Uma outra contribuição da nossa pesquisa, apesar de não estar entre seus objetivos, está na participação dos tecnoatores na produção dessas edições e no cruzamento de culturas 
que tem acontecido de alguma forma no âmbito das redações. Esses dispositivos demandam novos conhecimentos profissionais, porém, nem sempre isso é observado na prática. Constatamos que muitos desses repórteres e editores que trabalham nas versões para tablets são oriundos de outras plataformas e não possuem formação para atuar no suporte. Nesse caso, é com a experiência diária que vão aprendendo - esta ideia é reforçada pela teoria do habitus de Bourdieu (1998).

Jornalistas, programadores e designers também têm trabalhado em parceria nessas redações há algum tempo ${ }^{75}$. Como mostramos, há tensões e aprendizagens nesse processo. $\mathrm{O}$ que nossa observação indica é que a cultura jornalística prevalece, principalmente porque esses terrenos de embate estão no campo jornalístico. Todos os profissionais precisam falar uma mesma linguagem. Destacamos que houve casos, como no O Globo A Mais e no Zero Hora, que pautas foram derrubadas por esses profissionais. No carioca, pela incapacidade de o conteúdo ser produzido com enriquecimento, e no portalegrense, por não conseguirem executar o desejado pela redação. O que fica latente é que o tempo dos profissionais é diferente e este parece ser o maior entrave entre eles.

É relatado pelos jornalistas e tecnoatores da redação que estes embates já foram maiores e que hoje ambos os lados conseguem compreender melhor o tempo de trabalho de cada um. Há de alguma forma uma tentativa de mesclar as limitações e propor produtos que atendam às necessidades e à capacidade da redação.

Todo esse relato também possui alguma correlação com dois dos nossos objetivos específicos: (i) Mapear, debater e refletir sobre o estado da arte do jornalismo feito para tablets no Brasil; e (ii) Estruturar e identificar o processo de produção de uma edição para tablets.

O primeiro deles (que mostramos no capítulo III) é profícuo porque nos aponta que, nos jornais diários, os tablets deixam de ser interessantes em termos comerciais. Nossos dados relatam da ascensão à queda dos dispositivos como suportes para a prática jornalística. Tratase de um relato histórico, inédito, que certamente contribuirá para novas análises no campo de pesquisa.

O segundo objetivo específico revela-se um exercício bastante interessante para o nosso trabalho. Inspirados na descrição gráfica da microssociologia do newsmaking de Ericson, Baranek e Chan (1987) - capítulo II -, relatamos e refletimos sobre o fluxo de

\footnotetext{
${ }^{75}$ Essas tensões já existiam deste o desenvolvimento da diagramação. Contudo, com o lançamento de novos produtos que estão distante da formação recebida pelos jornalistas, novos profissionais são demandados para o desenvolvimento dessas peças.
} 
produção nas redações desses dispositivos. Essa descrição serviu de base também para confirmar, em parte, a segunda hipótese do trabalho: a integração das redações transformou a pauta em um organismo vivo, porém, nem sempre o seu conteúdo vai sendo adequado de acordo com as necessidades de cada suporte; bem como permitiu que o nosso terceiro objetivo específico fosse executado, que era elencar e analisar, no contexto de uma redação convergente, quais elementos são levados em consideração para a construção de uma pauta.

Nesse ponto, mais considerações precisam ser feitas. O processo de produção fica localizado na propositura das pautas. Elas surgem de variados locais e ganham ainda mais relevo com o desenvolvimento da digitalização da informação, com a internet e as bases de dados. Fontes, passivas ou ativas, e ideias (oriundas dos mais diversos lugares - aqui há um misto entre conhecimento individual e coletivo) também fazem parte dos primeiros passos no processo de criação de pautas em todos os suportes pesquisados. Ressaltamos que o grau dessas influências é diferente em cada suporte, seja pela importância dada pelos membros da redação, seja mesmo pela disponibilidade de dados.

A audiência sempre foi levada em consideração na hora da produção das informações. Entretanto, as métricas têm impactado profundamente algumas redações no processo de construção da informação. Este é o novo elemento quando falamos no processo de escolha das primeiras informações, antes de virar pauta. É curioso notar que, no âmbito das redações integradas, essas métricas têm influenciado toda a produção, inclusive do impresso principalmente porque o conteúdo é produzido para todas as plataformas. Esse processo não é uniforme em termos que utilização, pois os graus são variados e vão depender sempre dos recursos disponíveis.

O Globo A Mais, por exemplo, não possuía métricas de acesso, nem elas eram usadas para a produção de conteúdos. O que se sabia era que edições com determinados temas davam mais acesso do que outros. Então, apesar de terem alguma noção sobre o acesso, não tinham dados mais precisos para influenciar de modo decisivo no processo de escolha, o que não quer dizer que essas informações não eram levadas em consideração.

No Zero Hora era diferente - estamos falando agora da redação integrada, que produz conteúdo também pensando no tablet. Dados de diversas fontes eram utilizados para avaliar o conteúdo produzido e para pensar em novos. Desdobramentos de matérias, ou mesmo atualizações, dependiam desses dados. Como era uma produção com fluxo contínuo, duas reuniões de pauta integradas davam o tom dessa produção ininterrupta e avaliavam com números quantitativos o sucesso do produto. 
Uma reunião serviria para avaliar a outra e assim esse fluxo era constante. A reunião do ZH Noite, como frisamos, era mais para definir quais matérias entrariam e principalmente para deliberar sobre a capa. O que não destacamos em nossa observação anterior foi que a editora que participa da reunião com os repórteres também está presente na reunião de pauta integrada, o que permitia que levasse em consideração esses dados em alguns momentos.

No Diário do Nordeste, que também possui a redação integrada, números são igualmente importantes. O que vai diferenciar do Zero Hora é que, naquele suporte, há uma pessoa dentro da redação para pensar como potencializar os números. Não parece uma cultura generalizada entre todos os profissionais.

Nesse tópico, precisamos fazer uma observação que perpassa todo o trabalho: há elementos culturais que podem impactar na hora de criar conteúdos em todas as suas instâncias (produção, edição e circulação). Constatamos que existem profissionais mais resistentes quando o assunto é produzir para outra plataforma que não seja a do jornal impresso. Isso ficou muito claro na redação do Diário do Nordeste. Os jornalistas que trabalham nessa redação, sejam os do Diário do Nordeste Plus, ou da redação integrada, ainda possuem resistência quando o assunto é produção multiplataforma. Isso não quer dizer que os membros do DNPlus não estejam atentos às potencialidades oferecidas pelo suporte.

Com nossas observações, não estamos dizendo que as métricas substituem os critérios tradicionais para seleção de notícias, como os valores-notícia, mas sim alertando que esse elemento ganha destaque e está se projetando cada vez mais nas redações, podendo chegar a ser o critério principal para a seleção. Nas redações em que elas são mais usadas, os jornalistas relatam que os valores da profissão são mais fortes que os números de audiência apesar de afirmarem que trabalham para atingir elevados níveis de audiência.

Voltando ao mapeamento da produção, em um segundo instante desse nível, que ainda está atrelado aos três primeiros pontos (ideias, fontes e audiência), estão os profissionais que fazem parte da redação que propõe pautas. Qualquer membro da redação pode propor pauta, sejam eles jornalistas ou não. Por isso continuamos acreditando, como frisamos no capítulo IV, que a pauta não tem um formato estanque e vai evoluindo ao longo do trabalho pelo menos nesse primeiro instante. Há pautas que chegam anguladas, com fontes e apuração, outras aparecem mais em formato de ideias e vão sendo trabalhadas até passar para os editores (terceiro estágio do primeiro nível).

É dos editores a iniciativa de levar o assunto para a reunião de pauta. Por isso, chamamos também essa reunião de uma instância de adequação, de melhoramento, pois diversos profissionais tarimbados participam e dão sugestões para o melhoramento do 
assunto. Só depois de aprovado o tema ele seguirá adiante para ser trabalhado pelo repórter. Nas duas redações integradas, inclusive com modelos similares de integração, participam juntamente editores e tecnoatores.

A palavra final é do editor-chefe, ou, como é chamado na redação do Diário do Nordeste, diretor-editor. Todavia, depois dessa aprovação, os editores temáticos são os guardiões do trabalho. Mudanças de grande vulto e descobertas são debatidas por diferentes instâncias ao longo do dia. São micro-reuniões que acontecem a qualquer momento e podem alterar toda a programação do dia, chamada também de uma jornada do leitor.

A pauta de edição, apesar de não termos observado antes, mostra-se também uma jornada de leitura. A diferença agora é que ela está mais viva e rápida. Os fatos do dia podem alterar profundamente o planejamento de toda uma edição, como foi o caso do acidente de avião que matou o ministro do Supremo Tribunal Federal, Teori Zavascki, em Paraty, na Costa Verde do Rio de Janeiro.

Voltando mais uma vez ao processo de produção, o trabalho do repórter seria mais uma instância de alteração de pauta e daria o caráter dinâmico da pauta. Apuração e fontes sempre alteraram pautas. Equipe de cinegrafistas e repórteres-fotográficos também deram o tom nessas transformações, inviabilizando ou não uma matéria. Como frisamos anteriormente, os tablets publicam um conteúdo com um grau estético elevado por terem capacidade de alta resolução. Essa foi uma norma que foi adotada pelos jornais ao proporem suas versões. Isso vai tencionar também o processo de formação do produto jornalístico e é o repórter que será o mediador dessa construção. O jornalista também precisará lidar com a elaboração de produtos feitos pelos designers e programadores.

Após a finalização do conteúdo, mais uma vez os editores entram em ação para editá-lo, podendo ser devolvido ao repórter para acrescentar informações ou passar somente pela edição ${ }^{76}$. Este, como ressaltamos algumas vezes, é um fluxo ininterrupto e que vai acontecendo ao longo do dia. Depois de aprovado pelos editores, o produto vai para publicação.

Ressaltamos que a publicação de um tema há muito tempo representou o resultado final de um fluxo de produção. Hoje, com as métricas, esses dados podem voltar a circular, ser requentados e ganhar nova roupagem, o que nos possibilitou relatar uma produção circular que vai acontecer nas redações integradas e surte efeitos no resultado final do trabalho. Com isso, voltamos a afirmar que nossa segunda hipótese se confirma particialmente: a integração

\footnotetext{
${ }^{76}$ Alguns conteúdos passam por revisão depois dos editores. Na maioria dos casos os editores que revisam.
} 
das redações transforma a pauta em um organismo vivo; contudo, é importante destacar que nem sempre o conteúdo produzido pela redação vai sendo adequado de acordo com as necessidades de cada suporte. Disponibilidade de material também é um fator condicionante a essa adequação, como mostra a produção de conteúdo para o Zero Hora Noite.

Intuímos, apesar de não ser nosso objetivo, que por trás há elementos de cunho organizacional, de cariz econômico. Essa não é uma novidade para a profisssão, que tem seu florescimento a partir do campo econômico. Todavia, não deixa de ser uma ameaça ao jornalismo de qualidade, com um viés mais social - perto do ideário romântico relatado no capítulo II.

O terceiro e o quarto objetivos específicos foram mapear, no contexto de uma redação convergente, quais elementos são levados em consideração para a construção de uma pauta e refletir e especificar quais são os portões que a informação cruza para se tornar produto jornalístico para tablet. Colocamos os dois objetivos juntos aqui porque acreditamos que muitos dos elementos que serão expostos têm correlação e são complementares. Destacamos também que muitos deles já foram ventilados aqui.

Apesar de não ser um estudo sobre a teoria do Gatekeeping, utilizar a tipologia de Schumacher e Voz (2016) aumentou nossa capacidade de observar os processos de escolha e as instâncias de alteração da pauta, como abordamos no capítulo VI. Entendemos que as hierarquias desenvolvidas nos jornais servem também como amplificadores de controle e mudanças no processo de produção. Pensar em processo de seleção é pensar em pauta também. Propomos, como indica o gráfico 14, que a seleção de temas no processo da pauta acontece, de acordo com três níveis: 1) individual; 2) coletivo; e 3) institucional.

O que percebemos é que a passagem pelos portões dos meios de comunicação é polivalente. Os diversos atributos que a informação possuiu e a capacidade do profissional em avaliar essa informação estará entre os primeiros pontos levados em consideração.

O primeiro nível é pessoal, está mais relacionado a um corpo individual, mas isso não quer dizer que elementos coletivos, como o habitus do agente, não estejam em funcionamento para a indicação de temas. O que também é verdadeiro ao afirmarmos que os outros níveis, propostos por Shoemaker e Vos (2011), também encontram-se em ação. A proposta individual tem correlação com a decisão de quem propõe o conteúdo, isso não quer dizer que outras forças não estejam agindo para que ele tome a decisão. Como frisamos no capítulo, chamar a atenção do repórter para a construção da pauta é fundamental para que o editor aceite a sugestão e leve ao segundo nível. 
O segundo nível, o coletivo, está inoculado nos profissionais. Chamamos de nível coletivo porque é um portão de cunho mais dialógico. Aqui há tensões por todos os lados. Os interesses da empresa e dos jornalistas entram, em alguns momentos, em conflito latente nessa instância.

O terceiro nível, o institucional, incluindo a análise de variáveis como parâmetros de participação de propriedade na mídia, fica mais visível em locais com hierarquias mais verticalizadas, como no Diário do Nordeste. Em redações integradas, esse nível tende a equalizar as forças e percepções de mundo. Isso não quer dizer, mais uma vez, que não existam convenções entre os membros da redação.

Aqui funcionam também pressões veladas, incluindo influências do governo e grupos de interesse. Certamente esse aspecto influenciará o profissional de comunicação, na sua escolha, para ter mais segurança. Fontes estáveis fazem parte do ritual estratégico dos jornalistas e garantem o melhor funcionamento das rotinas. Isso é observado nos pressreleases diários, distribuídos pelas assessorias de comunicação das empresas públicas e privadas, que são consultados para a produção de pautas.

No âmbito das práticas, que fazem parte dos objetivos específicos, está o cuidado com a apuração. Nem todos os profissionais que propõem boas ideias fazem boa apuração. Para que seja apurada, e assim cruzar o primeiro portão, a informação (em estado bruto ou inicial) precisa ser trabalhada. Na maioria dos casos, a indicação de fonte para o desenvolvimento do texto aí acontece. Propomos, para que a pauta avance nessa etapa do portão, três pontos: angulação, levantamento de dados e fontes.

A reunião de pauta geral e/ou integrada é o ponto central do segundo portão. Caso o formato da reunião seja ampliado - e absorva profissionais de distintas editorias e origens -, é o repórter ou um não-jornalista que defende ideia. Como dissemos, quanto mais capital simbólico esse profissional possuir, mais fácil será sua aprovação. E nesse caso identificamos dois fatores: conhecimento e reputação como profissional.

O maior gatekeeper, o editor-geral ou função equivalente, interfere diferentemente neste ponto. É a partir dele que o repórter sai para campo e produz a informação. Os participantes da reunião de pauta com o editor-geral examinam a proposta e dão novas sugestões. É dele, auxiliado pelos editores, que parte a decisão final se o conteúdo será publicado ou não. Mais uma vez, todos os níveis propostos por Shoemaker e Vos (2011) entram em ação, só com uma visão mais coletiva e com profissionais de maior mando.

Neste ponto, apenas a apuração do repórter altera o foco do trabalho. E, mesmo assim, as alterações precisam ser comunicadas aos editores, que acompanham de perto o trabalho do 
subordinado. Há elementos que podem interferir nesse processo de tratamento jornalístico: a) as fontes e b) na parte material, a qualidade dos conteúdos midiáticos produzidos. As fontes tencionam para que as versões que sejam do seu interesse ganhem visibilidade.

Finalizado o trabalho de apuração, entram em ação os editores. A eles chegará o conteúdo para sua possível aprovação. Trata-se de um novo portão que pode re-mediar a pauta e os conteúdos que cruzam o último portão. A edição pode mudar rumos, caso seja necessário, ou seja, o repórter pode ser demandado a fazer uma nova alteração. Inconsistência na apuração, qualidade do conteúdo, títulos, legendas e construção de narrativa são observados nessa etapa.

Ao final deste trabalho, podemos reafirmar que a pauta é um roteiro ou agenda, oral ou escrita, dos principais assuntos a serem abordados na edição de um meio de comunicação noticioso (LUZ, 2005b) ou de um conteúdo jornalístico. Como resultado da pesquisa, enfatizamos que ela perpassa todo o processo produtivo. Com isso, estamos propondo que a pauta não é uma etapa estanque do processo de produção. Na contemporaneidade, ela torna-se um objeto vivo que permeia todas as etapas de produção e edição e vai evoluindo durante todo o desenrolar do trabalho de uma equipe jornalística, até desembocar na circulação do produto final.

Se olharmos para o passado, veremos que essa afirmação já está em voga há bastante tempo. O que vai diferenciar a pauta na atualidade é o ritmo frenético, a distribuição multiplataforma e as métricas, que aceleram o frenesi nas redações e transformam os métodos de produção. Como contribuição ao estudo da pauta, propomos algumas tipologias para organizar o tema, que dividimos em pauta de edição (macro) e pauta de conteúdo (micro). A primeira é desenvolvida e controlada por editores e dá uma visão geral dos temas que serão tratados na edição completa ou por horário. A segunda é feita por qualquer membro da redação e é referente a somente um assunto tratado. Com a constante alteração dos modelos de negócio e a mudanças nas estratégias comerciais, como apresentamos no capítulo III, existem diferentes tipos de organização das redações e formas de desenvolver o trabalho jornalístico. Com isso, estendemos nossa categorização para que a pauta de edição seja dividida em convergente, geral e por editoria; e a pauta micro seja apenas de conteúdo.

Essas classificações, ao fazer a observação participante, mostraram-se adequadas. Ainda hoje, em redações integradas ou não, funcionam sem que os profissionais que trabalham na redação façam distinção. Principalmente porque é algo integrado ao dia-a-dia dos jornalistas. 
Vale destacar que, pensar na pauta como organismo vivo, para nós, agora, faz mais sentido em redações integradas. A integração das redações transformam a pauta em um organismo latente, em que o conteúdo vai sendo adequado de acordo com as necessidades de cada suporte. É importante frisar que conseguimos perceber que não se trata de uma consequência da integração diretamente, mas de uma questão organizativa.

Locais com estruturas mais verticalizadas e com menor estrutura do trabalho estratificam esse tipo de fluxo, apesar de ele continuar acontecer. $\mathrm{O}$ reflexo disso são pautas mais rígidas e horizontalizadas, menos atentas à apuração e às múltiplas perspectivas que um assunto pode gerar. É interessante notar, também em nosso objeto de pesquisa, que foram as diferentes estratégias de produção de conteúdo observadas, o que proporcinou ampliar esse olhar.

Inicialmente, em 2014, ao observar o Globo A Mais, tivemos a oportunidade de identificar que a pauta era um dos elementos centrais no processo de produção. Ela era um componente diferenciador de outras publicações e uma alternativa de fidelizar a audiência. Jornalistas que atuavam no suporte não eram especialistas na plataforma e foram aprendendo uns com os outros. O resultado na pauta é que o repórter precisava ter a capacidade de pensar em um conteúdo que tivesse a possibilidade de ser enriquecido. Isso quer dizer que ele deveria criar produtos com capacidade interativa e multimidiática. É certo que a web já abriu caminhos para que esse tipo de produção fosse mais naturalizada. Mas novos elementos foram agregados ao processo de produção, como a dupla navegação e a tactilidade.

O que não vai acontecer com o Zero Hora Noite, que está dentro de uma redação integrada e que produz numa lógica de cross-media. Contudo, isso não impediu os profissionais que ali trabalham de ter a consciência da necessidade e, quando possível, buscam inserir conteúdo em formatos diferentes, com a máxima interatividade.

Com isso, podemos afirmar que somente aplicativos autóctones exploram as potencialidades do suporte. É preciso ter uma equipe pensando e produzindo conteúdo que esteja adequado ao formato. Isso só pode acontecer, no cenário que observamos, com profissionais capacitados em diferentes aéreas para dar conta das potencialidades oferecidas pelo tablet. Claro que este é um cenário ideal e não quer dizer que o ZH Noite não faz jornalismo para tablet.

A participação de outros profissionais nas reuniões de pauta, como programadores e designers representa um novo elemento ao processo de produção, na construção da pauta. Encontrar profissionais não-jornalistas que atuem positivamente em um local até então exclusivo de jornalistas acrescenta novos elementos à cultura profissional nos diferentes 
âmbitos - sobressaindo a jornalística. Esses elementos também são encontrados na primeira versão do Diário do Nordeste Plus. Com isso acreditamos que em versões exclusivas para tablets há uma re-mediação maior no processo. Como se trata de um ambiente essencialmente jornalístico, profissionais que chegam de outro campo precisa se naturalizar e absorver o habitus jornalístico para poder dialogar com os membros da redação.

Como continuidade do processo de construção da pauta, a questão organizativa está no centro do debate e se mantem como central na lógica de produção. Angulação também não se altera e continua sendo condição sine qua non na produção de pautas. Esse ponto estará sempre atrelado à proposta editorial do meio. Propor algo diferente, que apresente uma nova abordagem e que tenha impacto na vida da sociedade, continua sendo uma regra clássica na profissão.

No campo metodológico, precisamos fazer algumas observações. Inicialmente, a proposta se mostrou adequada. O primeiro ponto que destacamos é que ao adotar a sugestão bourdieusiana nosso trabalho apresenta particularidades. O peso conferido por Bourdieu (1998) à observância da prática dos agentes e ao interesse pelos diversos fenômenos sociais, não se restringindo somente às relações de coerção que esses agentes impõem, possibilita olhar para a pauta de forma mais ampla. Olhamos para os sistemas de produção do jornalismo como estruturas objetivas dos agentes, que na maioria das vezes são conscientes.

Além disso, a teoria nos alertou para o determinismo e a estabilidade das estruturas. Fica claro, nas práticas, que as ações, desde as mais pessoais, não pertencem ao sujeito e sim a um sistema complexo de relações. Principalmente ao percebermos elas se repetirem em ambientes tão distintos. Apesar dessas observações, não refutamos os aspectos relacionados aos indivíduos. $\mathrm{O}$ aspecto construtivista da proposta nos manteve atentos a uma gênese social dos esquemas de percepção, pensamento e ação que são constitutivos e forjam as estruturas objetivas.

Porém, dentro da complexidade da proposta metodológica, frisamos que a observação participante mostrou-se limitada quando o assunto é buscar compreender questões complexas como os capitais dos agentes e as lutas travadas no âmbito do campo. Destacamos também que o período no Diário do Nordeste e o não acesso às reuniões de pauta, prejudicaram a elaboração de uma análise mais apurada.

O clima e os ambientes observados não demonstram os conflitos entre os agentes dentro de cada campo, que são de cunho mais sutil. A monopolização de capitais específicos pelos agentes que acumularam mais capital (editores seriam um bom exemplo), possuindo 
maior poder pela via da violência simbólica (autoridade) contra os agentes com pretensão à dominação, os desfavorecidos.

Como Bourdieu (1999) nos alerta, não se trata de uma luta aberta, no modelo "classe dominante" contra a "classe dominada", mas de uma violência simbólica sutil, em que a dominação nem sempre é evidente ou explícita. A violência faz parte do sistema e é legitimada por cada campo, em que as práticas e instituições dotam os agentes dominantes com os ganhos advindos de todos os tipos de capital. A dominação é efeito de um conjunto de ações, complexamente engendrado, que escapa à consciência de cada um dos agentes e do comportamento das instituições dominantes sobre os demais. Esses esquemas de percepção são claros nas redações observadas.

O processo de aprovação da pauta, nos seus diferentes níveis, passa por esse tipo de relação. Editores-chefes são representantes das empresas jornalísticas e defendem os interesses delas. Ao nos referir aos repórteres como mais engajados em questões sociais estamos de alguma forma nos referindo a um embate de duas forças até então antagônicas: empresa x sociedade. Entretanto, apesar de fazerem parte desse processo, estes aspectos não estão em nosso horizonte de pesquisa, o que pode demonstrar uma possível limitação da pesquisa.

Constatamos também no processo produtivo o que Bourdieu (1997) chama de restrições e controles cruzados. Estes controles, os jornalistas os impõem uns aos outros, interpretados nesse caso como princípios deontológicos, inclusive como princípio basilar da reputação de honorabilidade profissional. Muitas vezes eles vão além desses princípios, como os manuais de redação. Profissionais com maior capital (social, cultural e simbólico) tendem a exercer mais influência sobre outros profissionais. Esses capitais, como elencamos no capítulo I, referem-se às habilidades, ao conhecimento e às informações formados em diversos âmbitos. O que percebemos é que esse momento não é uma unanimidade e que, dependendo da redação, essa horizontalidade não é clara. Pelo contrário, há uma verticalização pela lógica. Um dos possíveis motivos está em uma cultura do impresso, como é o caso do Diário do Nordeste.

Frisamos também que, entre as limitações deste trabalho, destacamos a revisão de literatura no âmbito bourdiesiano e sobre convergência. Por não ser nosso foco direto do trabalho, acabamos optando por centrar mais a revisão nos trabalhos mais direcionados à pauta e às rotinas jornalísticas. Nesse aspecto, as observações de uma semana, no Zero Hora, e dois dias, no Diário do Nordeste, não se mostraram tão eficazes para observar de forma 
detalhada essas nuances propostas por Schumacher e Voz (2016) e também por Bourdieu (1999).

Como desdobramento da pesquisa, indicamos que, além de etnografia, sejam também observadas as publicações dos editores. Primeiro, para entender quais valores-notícia são utilizadas para publicação do conteúdo e como eles são mobilizados - métricas influenciam? Feito isso, em segundo lugar, sugeriríamos observar quais fontes e quais tipos de arquivos foram gerados. Formatos são escolhidos por se adequarem mais ou são uma combinação de competência e disponibilidade da redação? Essa proposta busca estabelecer a relação entre valores-notícia, formatos e fontes mobilizadas no processo de construção da notícia. A observação possibilitará identificar quais recursos serão utilizados para a cobertura. Indicará também quais critérios os editores empregaram ao tomar a decisão (como exemplo as métricas). O que nosso estudo mostra é que a pauta é uma combinação de fatores amplos e que precisam ser melhor elucidados. 


\section{REFERÊNCIAS}

ADGHIRNI, Zelia Leal. Rotinas produtivas do jornalismo em Brasília. In: MOUILLAUD, M.; PORTO, S.D. (Org.). O Jornal: da forma ao sentido. 3. ed. Brasília: Ed. UnB, p. 519$538,2012$.

ADGHIRNI, Z. L; JORGE, T. M. Mudanças estruturais no jornalismo: convergir é preciso. Reflexões sobre as empresas, a convergência de redações e o perfil dos profissionais. In I Colóquio Internacional Mudanças Estruturais no Jornalismo. Convergir é preciso: Reflexões sobre as empresas, a convergência de redações e o perfil dos profissionais. 2011.

AGUADO, Juan Miguel; CASTELLET, Andreu. Contenidos digitales en el entorno móvil: mapa de situación para marcas informativas y usuarios. In: BARBOSA, Suzana; MIELNICZUK, Luciana (Org.). Jornalismo e Tecnologias Móveis. 1. ed. Covilhã: Livros LabCOM, p. 25-49, 2013.

AGNEZ, Luciane. A convergência digital na produção da notícia. Reconfigurações na rotina produtiva dos jornais Tribuna do Norte e Extra. 2011. Mestrado (Dissertação) Faculdade de Comunicação, Universidade Federal do Rio Grande do Norte, Natal, 2011.

ALTHEIDE, D.L. Creating Reality. Beverly Hills, CA: Sage. 1976.

ALLEN, C. Discovering "Joe Six Pack" content in television news: The hidden history of audience research, news consultants, and the Warner Class model. Journal of brodcasting \& eletronic media. V.3 N.51. 2005.

; CRAWFORD, Kate. A Liminal Press: Situating news app designers within a field of networked news production. Digital Journalism, v. 3, n. 2, p. 192-208, 2015.

ALSINA, Miquel Rodrigo. A Construção da Notícia. Petrópolis: Editora Vozes, 2009.

ANDERSON, C.W., Bell, E., Shirky, C.. Post-Industrial Journalism: adapting to the present. Columbia Journalism School - Tow Center for Digital Journalism. 2012. Disponível em: $\quad<$ http://towcenter.org/research/post-industrial-journalism-adaptingto-the-present- $2 />$. Acesso em 23 de jan. 2015.

BAHIA, Juarez. Jornal, História e Técnica: as técnicas de jornalismo. 4 ed. São Paulo: Ática, 1990.

BARBOSA, Suzana. Jornalismo digital em base de dados (JDBD): um paradigma para produtos jornalísticos digitais dinâmicos. 2007. 331 f. Tese (Doutorado em Comunicação e Cultura Contemporânea) - Faculdade de Comunicação, Universidade Federal da Bahia, Salvador, 2007.

Jornalismo convergente e continuum multimídia na quinta geração do jornalismo nas redes digitais. In: João Canavilhas. (Org.). Notícias e Mobilidade. O Jornalismo na Era dos Dispositivos Móveis.. 1ed.Covilhã: Livros LabCOM, v. 1. p. 33 - 542013. 
Aspectos da convergência jornalística em empresas informativas brasileiras. In: $6^{\circ}$ CONGRESSO SOPCOM. Anais... Universidade Lusófona de Humanidades e Tecnologias, Lisboa, 2009.

. Jornalismo convergente e continuum multimídia na quinta geração do jornalismo nas redes digitais. In: CANAVILHAS, J. (Org.). Notícias e Mobilidade. O Jornalismo na Era dos Dispositivos Móveis. 1ed.Covilhã: Livros LabCOM, v. 1, p. 33-54, 2013.

; SEIXAS, Lia. Percepções, usos e tendências. In: BARBOSA, Suzana et al (Org.). Jornalismo e Tecnologias Móveis. 1. ed. Covilhã: Livros LabCOM, 2013.

; SILVA, F. F. da; NOGUEIRA, L; ALMEIDA, Y. A atuação jornalística em plataformas móveis. Estudo sobre produtos autóctones e a mudança no estatuto do jornalista. In: II COLÓQUIO INTERNACIONAL MUDANÇAS ESTRUTURAIS NO JORNALISMO. Anais... Natal, Universidade Federal do Rio Grande do Norte, 2013.

BASS, A.Z. Refining the "Gatekeeper" Concept: a UN Radio Case Study. Journalism \& Mass Communication Quarterly, v. 46, n. 1, p. 69-72, 1969.

BEAM, Randal A. Content Differences between Daily Newspapers with Strong and Weak Market Orientations. Journalism \& Mass Communication Quarterly V.2 N.80. 2003. 368390

BERNARDES, Cristiane Brum. As rotinas de produção da pauta de um jornal popular. Observatório da Imprensa, São Paulo, 23 dez. 2003.

BOLTER, J. D.; GRUSIN, R. Remediation: Understanding New Media. Cambridge: The MIT Press, 2000.

BOURDIEU, Pierre. O poder simbólico. Bertrand, Rio de Janeiro, 1998.

. Coisas ditas. São Paulo: Brasiliense, 1990.

. Sobre a televisão. Rio de Janeiro, Zahar, 1997.

BREED, Warren. Social control in the newsroom: A functional analysis. Social Forces, v. 33, n. 4, p. 326-335, mai. 1955.

BRIN, Colette; CHARRON, Jean; BONVILLE, Jean. Nature et transformation du journalisme: théories et recherches empiriques. Québec: Les Presses de L'Université Laval, 2004.

CANAVILHAS, João. Da remediação à convergência: um olhar sobre os media portugueses. Brazilian Journalism Research, v. 8, n. 1, 2012. p. 7-21.

. Contenidos informativos para móviles: estúdio de aplicaciones para iPhone. Revista Textual \& Visual Media, Madrid, n. 2, 2009, p. 61-80. 
Modelos informativos para aparatos móviles: información hipermultimediática y Personalizada. In: IV CONGRESO INTERNACIONAL LATINA DE COMUNICACIÓN SOCIAL: Comunicación, control y resistencias. Actas... Sociedad Latina de Comunicación Social, p. 1-15, 2012 b.

; SANTANA, Douglas. Jornalismo para plataformas móveis de 2008 a 2011: da autonomia a emancipação. Revista Líbero, São Paulo, v. 14, n. 28, p. 53-66, 2011.

; SATUF, Ivan ; LUNA, D. ; TORRES, Victor ; BACCIN, A. ; MARQUES, Alberto, . Jornalistas e tecnoatores: a negociação de culturas profissionais em redações on-line 1. Revista FAMECOS (Impresso), v. 23, p., 2016.

; __ _ LUNA, Diógenes; TORRES, Vitor. Jornalistas e tecnoatores: dois mundos, duas culturas, um objetivo. Esferas, a. 3, n. 5, p. 85-95, 2014.

CASTELLET, A. El ecosistema del contenido móvil: Actores, líneas de evolución y factores de disrupción. 2012. 408 f. Tesis Doctoral - Facultad de Comunicacíon y Documentacíon, Universidad de Murcia, 2012.

; FEIJOÓ, Claudio. Los actores en el ecosistema móvil. In: AGUADO, Juan Miguel; FEIJOÓ, Claudio; MARTÍNEZ, Inmaculada J. (Coord.). La comunicación móvil: hacia un nuevo ecosistema digital. Barcelona: Gedisa, p. 27-56, 2013.

CHALABY, Jean. Journalism as an Anglo-American Invention: A comparison of the Development of French and Anglo-American Journalism, 1830s-1920s. European Journal of Communication, v. 11, n. 3, p. 303-326, 1996.

CHIBNALL, Steve. Law and order News: An analysis of crime reporting in the British press London: Tavistock, 1977.

CUNHA, Rodrigo do Espírito Santo da. Revistas no cenário da mobilidade: a interface das edições digitais para tablets. 2011. 150 f. il. Dissertação (Mestrado) - Faculdade de Comunicação, Universidade Federal da Bahia, Salvador, 2012.

Design de informação em produtos jornalísticos para tablets: uma comparação Brasil-Espanha. 2015. 263 f. il. Tese (Doutorado em Comunicação e Cultura Contemporâneas) - Faculdade de Comunicação, Universidade Federal da Bahia, Salvador, 2015.

; ARAGÃO, R. Clicar, arrastar, girar: o conceito de interatividade em revistas para iPad. In: $9^{\circ}$ ENCONTRO NACIONAL DE PESQUISADORES EM JORNALISMO. Anais... Associação Brasileira de Pesquisadores em Jornalismo. Rio de Janeiro, Universidade Federal do Rio de Janeiro, nov. 2011.

; FREIRE, Marcelo. O jogo da leitura: a ludicidade no jornalismo para tablete. Contemporeanea, Salvador, 2017. No prelo

DAILEY, Larry; DEMO, Lori; SPILLMAN, Mary. The convergence continuum: A model for studying collaboration between media newsrooms. Atlantic Journal of Communication, v. 13, n. 3, 2005, p. 150-168. 
DEUZE, M., WITSCHGE, T. Além do Jornalismo. Leituras do Jornalismo, V. 02, N. 02, 2015, p. 1-31.

DE FONTCUBERTA, M. Pauta y calidad informativa. Cuadernos de información, n. 13, p. 61-69, 1999.

Domingo, D. et al.. "Four dimensions of journalistic convergence: A preliminary approach to current media trends at Spain". 8th International Symposium on Online Journalism, Austin, Texas, 2007. Disponível em : $<$ http://journalism.utexas.edu/onlinejournalism/2007/papers/Domingo.pdf $>$ Acesso em 23 jan. de 2013

DORTIER, Jean-François. À propos de Méditations Pascaliennes. Sciences Humaines, Numéro Spécial - Pierre Bourdieu, p. 54-57, 2002.

PELETZ, David e DUNN, Robert. Press coverage of civil disorders: a case study of WinstonSalem, 1967. Public Opinion Quarterly, n. 33, 1969. p. 328-345.

ERBOLATO, Mário L. Técnicas de codificação em jornalismo: redação, captação e edição no jornal diário. São Paulo: Ática, 1991.

ERICSON, R. V.; BARANEK, P. M.; CHAN, J. B. Visualizing deviance: a study of news organization. Toronto, Canada: University of Toroto Press, 1987.

FISHMAN, Mark. Manufacturing the news. Austin: University of Texas Press, 1988.

FOLHA DE S. PAULO. Manual de Redação. São Paulo: Publifolha, 2001.

FRANCISCATO, Carlos Eduardo. A atualidade no jornalismo: bases para sua delimitação teórica. 2003. 336 f. Tese (Doutorado) - Universidade Federal da Bahia, Faculdade de Comunicação, Salvador. 2011.

G1. Apple anuncia iPad Pro, modelo do tablet com tela de 12,9 polegadas. 09 set. 2015. Disponível em: <http://g1.globo.com/tecnologia/noticia/2015/09/apple-anunciaipad-promodelo-do-tablet-com-tela-de-129-polegadas.html>. Acesso em: 9 out. 2015.

G1. Apple apresenta iPad, prancheta digital com acesso à internet. 27 jan. 2010. Disponível em: <http://g1.globo.com/Noticias/Tecnologia/0,MUL1465371-6174,00APPLE+APRESENTA+IPAD+PRANCHETA+DIGITAL+COM+ACESSO+A+INTERNET. html>. Acesso em: 06 abr. 2015.

GALTUNG, Johan e RUGE, Mari Holmboe. The Structure of Foreign News. The Presentation of the Congo, Cuba, and Cyprus Crises in Four Norwegian Newspapers, Journal of Peace Research. V1. N2: 1965, p. 64-91.

GANS, Herbert J. Deciding what's news: a study of CBS Evening News, NBC Nightly News, Newsweek and Time. Evanston: Northwestern University Press, 1979. 
GARCÍA, José Alberto A.; SALAVERRÍA, Ramón; MASIP, Pere. Convergencia periodística en los medios de comunicación. Propuesta de definición conceptual y operativa. In: I CONGRESO DE LA ASOCIACIÓN ESPAÑOLA DE INVESTIGADORES EN COMUNICACIÓN. Anais... Santiago de Compostela, 2008.

GARCÍA, Mario. iPad Design Lab - Basic: Storytelling in the Age of the Tablet. North Light Books, 2012.

GENRO FILHO, Adelmo. O segredo da pirâmide: para uma teoria marxista do jornalismo. Porto Alegre: Tchê, 1987.

GRUSIN, Richard. Premediation: Affect and Mediality After 9/11. UK: Palgrave Macmillan, 2010 .

GIEBER, Walter. Across the Desk: A Study of 16 Telegraph Editors. Journalism \& Mass Communication Quarterly, v. 33, n. 4, p. 423-432, 1956.

GIL, A. C. Métodos e técnicas de pesquisa social. 6. ed., São Paulo: Atlas, 2010.

GOMES, Rui Miguel. A importância da Internet para jornalistas e fontes. Lisboa: Livros Horizonte, 2009.

GÜERE, H. N.; NEVES, Alysson L. Introducción a las Apps de noticias para dispositivos móviles. $\quad$ AE-IC 2012. Disponível em: $<\mathrm{http}: / / \mathrm{www}$. aeic2012tarragona.org/comunicacions_cd/ok/104.pdf>. Acesso em: 23 set. 2013.

GREENE-GONZÁLEZ, M.F., LECAROS-MENÉNDEZ, M.J. El trabajo del editor y la pauta en medios online chilenos. Palabra Clave 18(2), 588-613. 2015.

Grohmann, Rafael (2008), Cultura Jornalística: tempo, ritual, hierarquia e newsmaking na TV Alterosa de Juiz de Fora. In: XXXI Intercom, 2008, Natal/RN, Anais do XXXI Intercom.

HALlin, Daniel C. e MANCINI, Paolo. Comparing Media Systems: Three Models of Media and Politics. Cambridge University Press, 2004

HENN, Ronaldo. A pauta e a notícia: uma abordagem semiótica. Canoas: ED Ulbra, 1996.

JENKINS, Henry. Convergence culture: la cultura de la convergencia de los medios de comunicación. Barcelona: Ediciones Paidós Ibérica. 2008.

JORGE, Thaís de Mendonça. Manual do foca: guia de sobrevivência para jornalistas. São Paulo: Contexto, 2010.

KOLODZY, Janet. Practicing convergence journalism: an introduction to crossmedia storytelling. Nova Iorque: Routledge, 2012.

LAGE, Nilson. A reportagem: teoria e técnica de entrevista e pesquisa jornalística. Rio de Janeiro: Record, 2001. 189 p. 
LEMOS, André. Cidade e mobilidade. Telefones celulares, funções pós-massivas e territórios informacionais. MATRIZes, v. 1, n. 1, 2007.

LUZ, Cristina Rego Monteiro da. A pauta jornalística e suas mediações. 2005. Tese (Doutorado em Comunicação) - Universidade Federal do Rio de Janeiro, Rio de Janeiro, 2005a.

LUZ, Cristina Rego Monteiro da. Um olhar sobre a pauta: O fio de Ariadne. Comum, Rio de Janeiro, v. 11, n. 25, p. 92-134, julho/dez 2005b.

MARQUES, Alberto,. Rotinas jornalísticas no Globo A Mais: um olhar sobre a coleta e edição de conteúdos. In: CANAVILHAS, João; SATUF, Ivan. (Org.). Jornalismo para dispositivos móveis: produção, distribuição e consumo. 1ed.Covilhã: Labcom, 2015, v. 1, p. 221-240.

Tablets e jornalismo: o estado da arte e a multimidialidade no Estadão Noite e no Globo A Mais. In: IV CONFERENCIA ICA DE COMUNICAÇÃO DA AMÉRICA LATINA, 2014, Brasília. Anais... Brasília: UnB, 2014a.

. Redações convergentes e o impacto dos tablets nas rotinas produtivas jornalísticas. In: V SIMPÓSIO INTERNACIONAL DE CIBERJORNALISMO, 2014, Campo Grande. Anais... Campo Grande: UFMS, 2014b. Disponível em: $<$ http://www.ciberjor.ufms.br/ciberjor5/files/2014/07/alberto.pdf>. Acesso em: jan. 2015.

MARQUES, Luís Henrique. Teoria e prática de redação para jornalismo impresso. Bauru, SP: EDUSC, 2003.

MARTINS, Leo. É tempo de uma nova forma de fazer notícia. O Globo, Rio de Janeiro, 5 abr. 2014. Disponível em: <http://oglobo.globo.com/brasil/e-tempo-de-uma-nova-forma-defazer-noticia-12100886>. Acesso em: 21 jun. 2014.

PINTO, Manuel. FONTES JORNALÍSTICAS: CONTRIBUTOS PARA O MAPEAMENTO DO CAMPO. Comunicação e Sociedade 2, Cadernos do Noroeste, Série Comunicação, v. 14 (1-2), p. 277-294, 2000.

PINTO, Ana Estela de Sousa. Jornalismo diário: reflexões, recomendações, dicas e exercícios. São Paulo: Publifolha, 2009. å

MCQUAIL, Denis; WINDAHL, Sven. Communication Models for the Study of Mass Communications. London: Longman, 1993.

MCNELLY, J. T. Intermediary communicators in the international flow of news. Journalism \& Mass Communication Quarterly, v 36, n. 1, p. 23-26, 1959.

MIDITSCH, Eduardo; SCHWAAB, Reges. Jornalismo. In: CITELLI, Adilson; BERGER, Christa; BACCEGA, Maria Aparecida; IMMACOLATA, Maria; FRANÇA, Vera. Dicionário de comunicação: escolas, teorias e autores. São Paulo: Contexto, 2014. 
MIELNICZUK, L. Jornalismo na Web: uma contribuição para o estudo do formato da notícia na escrita hipertextual. 2003. 246 f. Tese (Doutorado em Comunicação e Cultura Contemporâneas) - Faculdade de Comunicação, Universidade Federal da Bahia, Salvador. 2003.

MOLOTCH, H.; LESTER, M., News as purposive behavior: on the strategic use of routine events, accidents, and scandals. American Sociological Review. v. 39, p. 101-112, 1974.

NEVEU, Érik. Sociologia do jornalismo. Tradução de Daniela Dariano. São Paulo: Loyola, 2006.

Revisiting narrative journalism as one of the futures of journalism. Journalism Studies, Taylor \& Francis (Routledge): SSH Titles, v. 15, n. 5, p. 533-542, 2014.

OLIVEIRA, Michelle Roxo. A emergência do jornalismo informativo e a construção de representações da identidade profissional. Revista PJ:BR, 5. ed., $1^{\circ}$ semestre de 2005, Universidade de São Paulo.

OBLIZINER, Alfredo. A pauta é a notícia ou a notícia é a pauta?. Dissertação (Mestrado em Comunicação) - Faculdade de Comunicação, Universidade de Brasília, Brasília, 1997.

PALACIOS, Marcos; MACHADO, Elias (Org.). Modelos de jornalismo digital. Salvador: Casandra, 2003.

MACHADO, Elias; PALACIOS, Marcos. Um modelo híbrido de pesquisa: a metodologia aplicada ao GJOL. In: MACHADO, Márcia B; LAGO, Cláudia. (Orgs.). Metodologia de pesquisa em jornalismo. v. 1. 3. ed. Petropolis: Vozes, 2010. p. 199-222

; BARBOSA, S.; SILVA, F.; CUNHA, R. Aplicativos jornalísticos vespertinos para tablets. Cartografia do fenômeno ante o desafio de uma produção original e inovadora. Sur le journalisme, About journalism, Sobre jornalismo, v. 3, n. 2, p. 40-55, 2014.

; _ $\quad ; \quad ; \quad$ Mobile Journalism and Innovation: a study on content formats of autochthonous news apps for tablets. In: AGUADO, J.; FEIJOÓ, C.; MARTINEZ, I. (Org.). Mobile Content Evolution: Players, Challenges and Perspectives, Pennsylvania: IGI Global. 2015a. em narrativas para aplicativos em tablets e smartphones. In: CANAVILHAS, J.; SATUF, I. (Org.). Jornalismo para Dispositivos Móveis: produção, distribuição e consumo. Covilhã, UBI: LabCom, Livros LabCom, p. 7-42. 2015 b.

; CUNHA, R. A tactilidade em dispositivos móveis: primeiras reflexões e ensaio de tipologias. Contemporânea: Comunicação e Cultura, v. 10, n. 3, p. 668-685, 2012.

PUENTE, Soledad; EDWARDS, Cristóbal; DELPIANO, María Olga. Modelamiento de los aspectos intervinientes en el proceso de pauta periodística. Palabra Clave, v. 17, n. 1, p. 186208, 2014. 
QUIROGA, Tiago Fausto Neto. Comunicação, andança, restauração: possibilidades de uma episteme comunicacional. 2009. 241 f. Tese (Doutorado em Comunicação) - Programa de Pós-Graduação em Ciências da Comunicação, Escola de Comunicação e Artes, São Paulo, 2009.

RABACA, C. A.; BARBOSA, G. Dicionário de comunicação. Rio de Janeiro: Elsevier, 2001.

SATUF, Ivan. Aplicativos agregadores de informação jornalística para dispositivos móveis: Uma exploração pela Teoria Ator-Rede. 2016. 289 f. Tese (Doutorado em Comunicação) Universidade Da Beira Interior, Covilhã, 2016.

ROBINSON, S. Convergence crises: News work and news space in the digitally transforming newsroom. Journal of Communication, v. 61, n. 6, p. 1122-1141, 2011.

ROSHCO, Bernard. Newsmaking. Chicago: University of Chicago Press, 1975.

RUBLESCKI, A.; BARICHELO, E.; DUTRA, F. Apps jornalísticas: panorama brasileiro. In: CANAVILHAS, João (Org.). Notícias e Mobilidade: o jornalismo, na era dos dispositivos móveis. Labcom-Laboratório de Comunicação e Conteúdos Online, p. 121-140, 2013.

SALAVERRÍA, R. Multimedialidade: Informar para cinco sentidos. In: CANAVILHAS, João (Org). Webjornalismo: 7 características que marcam a diferença. Covilhã, UBI: LabCom, Livros LabCom, p. 25-52, 2014.

SALAVERRÍA, Ramón; GARCIA AVILÉS, José Alberto; MASIP, Pere. Concepto de Convergencia de Medios. LOPEZ, Xosé; PEREIRA, Xosé (org). Convergencia Digital: Reconfiguración de los Medios de Comunicación en España. Santiago de Compostela: Servizo de Publicacións e Intercambio Científico, 2010. p. 41-64.

Siete periodismos con futuro. In: ROITBERG, G.; PICCATO, F. (Comp.) Periodismo disruptivo: Dilemas y estrategias para la innovación. Buenos Aires: La Crujía, p. 137-144, 2015.

; GARCÍA-AVILÉS, J. A. La convergencia tecnológica en los medios de comunicación: retos para el periodismo. Trípodos, v. 23, p. 31-47, 2008.

; MASIP, P. Concepto de convergencia periodística. In: GARCÍA, L.; FARIÑA, P. (Coord.). Convergencia digital: Reconfiguración de los medios de comunicación en España. Santiago de Compostela: Servicio editorial de la Universidade de Santiago de Compostela, p. 41-64, 2010.

SIGAL, Leon V., Reporters and officials. The organization and politics of newsgathering. Lexington, Massachussets, 1973.

SCHUDSON, M. Descobrindo a notícia: uma história social dos jornais nos Estados Unidos. Petrópolis: Vozes, 2010.

SCHWINGEL, Carla. Mídias digitais: produção de conteúdo para web. São Paulo: Paulinas, 2012. 
SETTON, Maria da Graça Jacintho. A teoria do habitus em Pierre Bourdieu: uma leitura contemporânea. Revista Brasileira de Educação, n. 20, p. 60-70, maio/jun./jul./ago. 2002.

SERRANO, Filipe Tavares. iPad chega, finalmente, ao mercado brasileiro. Estadão. 29 nov. 2010. Disponível em: <http://www.estadao.com.br/blogs/jt-seubolso/2010/11/29/ipad-chegafinalmente-ao-mercado-brasileiro/>. Acesso em: 12 set. 2015.

SHOEMAKER, Pamela J., VOS, Tim P. Teoria do gatekeeping: seleção e construção da notícia. Porto Alegre: Editora Penso, 2011.

; EICHHOLZ, M.; KIM, E; WRIGLEY, B. Individual and routine forces in gate keeping. Journalism and Mass Communication Quarterly, v. 78, n. 2, p. 233-246, 2001.

; __ _ _ _ _ _ _ _ _ _ _ the United States. Brazilian Journalism Research, v. 6, n. 1, p. 55-77, 2010.

SHOEMAKER. Pamela. J. VOS, Tim P. Teoria do gatekeeping: Seleção e construção da notícia. Tradução: Vivian Nickel. Porto Alegre: Penso, 2011

SHOEMAKER, P. Gatekeeping. Newbury Park: Sage Publications. 1991.

, Hardwired for news: Using biological and cultural evolution to explain the surveillance function. Journal of Communication, Vol 46(3), 1996, 32-47. Dis-ponível em: $<$ http://dx.doi.org/10.1111/j.1460-2466.1996.tb01487.x>.Acesso: 15 de junho de 2016.

; JOHNSON, Philip; SEO, Hyunjin; WANG, Xiuli. Audience gatekeeping: A study of the New York Times most-emailed news items. In: Conference on convergence and society: The Participatory Web (3.0), University of South Carolina, Columbia, SC, 2008.

SILVA, Fernando Firmino da. Jornalismo live streaming: tempo real, mobilidade e espaço urbano. In: VI ENCONTRO NACIONAL DE PESQUISADORES EM JORNALISMO SBPJOR, 2008, São Bernardo do Campo. Anais... São Bernardo do Campo: UMESP, 2008.

Jornalismo móvel digital: o uso das tecnologias móveis digitais e a reconfiguração das rotinas de produção da reportagem de campo. 2013. 408 f. Tese (Doutorado em Comunicação e Cultura Contemporâneas) - Faculdade de Comunicação Social, Universidade Federal da Bahia, Salvador, 2013.

- Smartphones e tablets na produção jornalística. ÂNCORA Revista Latinoamericana de Jornalismo, v. 1, n. 1, 2014.

SILVA, Fernando Firmino da. Jornalismo Reconfigurado: tecnologias móveis e conexões sem fio na reportagem de campo. In: XXXI Congresso Brasileiro de Ciências da Comunicação INTERCOM, 2008, Natal - RN. INTERCOM 2008 - 2 a 6 de setembro, 2008.

SILVA, Gilda Olinto do Valle. Capital cultural, classe e gênero em Bourdieu. Informare Cad.Prog.Pós-Grado.Ci.Inf., Rio de Janeiro, v. 1, n. 2, p. 24-36, jul./dez. 1995. 
SILVA, Gislene. De que campo do jornalismo estamos falando?. Matrizes, São Paulo, ano 3, n. 1, p. 197-212, ago./dez. 2009.

SINGER, Jane B. Strange bedfellows? The diffusion of convergence in four news organizations. Journalism studies, v. 5, n. 1, p. 3-18, 2004.

SMITH, Anthony. Goodbye, Gutenberg: The newspaper revolution of the 1980s. Oxford University Press, 1980.

SCHMITZ, Aldo Antonio. Fontes de notícias: ações e estratégias das fontes empresariais nas relações com jornalistas de economia e negócios. 2010. 355 f. 1. Dissertação (Mestrado) Faculdade de Comunicação, Universidade Federal de Santa Catarina, Florianópolis, SC, 2010.

Reconstrucción del escenario mediático: el periódico que viene. Infoamérica: Iberoamerican Communication Review, n. 2, p. 7-19, 2010.

SODRÉ, Muniz; FERRARI, Maria Helena. Técnica de reportagem: notas sobre a narrativa jornalística. São Paulo: Summus Editorial, 1986.

SOUZA, Jorge Pedro. Uma história breve do jornalismo no ocidente. 2008. Disponível em: $<$ http://bocc.unisinos.br/pag/sousa-jorge-pedro-uma-historia-breve-do-jornalismo-noocidente.pdf $>$. Acesso em: 8 jul. 2016.

SNODGRASS, J. G., LEVY-BERGER, G., e HAYDON, M.. Human experimental psychology. New York: Oxford University Press, 1985.

STERNBERG, R. J.. Cognitive psychology. New York: Harcourt Brace, 2nd ed.,1999.

THIRY-CHERQUES, Hermano Roberto. Pierre Bourdieu: a teoria na prática. Revista de Administração Pública, v. 40, n. 1, p. 27-55, jan./fev. 2006.

TRAQUINA, Nelson. Jornalismo: questões, teorias e 'estórias'. 2. ed. Lisboa: Vega, 1999.

. O que é jornalismo. 1. ed. Lisboa: Quimera Editores, 2002.

$2005 \mathrm{a}$.

Teorias do jornalismo. V. I. Porque as notícias são como são. Florianópolis: Insular,

Teorias do jornalismo. V. II. A tribo jornalística: uma comunidade interpretativa transnacional. Florianópolis: Insular, 2005b.

TRIVIÑOS, Augusto Nibaldo Silva. Introdução à Pesquisa em Ciências Sociais: A Pesquisa Qualitativa em Educação. 1. ed. São Paulo: Atlas, 2011.

TUCHMAN, Gaye. Making news: A study in the construction of reality. New York: The Free Press, 1978.

. The production of news. In K.B. Jensen, A Handbook of Media and Communication Research: Qualitative and quantitative methodologies. London: Routledge, 2002. 
TUNSTALL, J.T. Journalists at Work. London: Constable. 1971.

VALENTINI, Elena. Dalle gazzette all'iPad: Il giornalismo al tempo dei tablete. Milano: Mondadori, 2012.

VANDENBERGHE, Frédéric. The real is relational: an epistemological analysis of Pierre Bourdieu's generative structuralism. Sociological Theory, v. 17, n. 1, p. 32-67, 1999.

WHITE, David Manning. The "Gatekeeper": A Case Study In the Selection of News. In: DEXTER, Lewis A.; WHITE, David M. (Org.): People, Society and Mass Communications. London S, p. 160-172, 1964.

WOLF, Cornelia; SCHNAUBER, Anna. News Consumption in the Mobile Era: The role of mobile devices and traditional journalism's content within the user's information repertoire. Digital Journalism, v. 3, p. 1-18, 2015.

WOLF, M. Teorias da Comunicação. Lisboa: Presença, 2003.

YIN, Robert K. Estudo de caso: planejamento e métodos. 3. ed. Porto Alegre: Bookman, 2005.

ZELIZER, Barbie. Talking Journalism Seriously. Sage Publications. London, 2004. 
APÊNDICES 
APÊNDICE A: Formulário de entrevista com os editores de O Globo A Mais

Nome:

Tempo de profissão:

Formação e experiências profissionais:

\section{Parte - A construção da Pauta}

Como são sugeridos e quais critérios são utilizados para a escolha dos temas que estarão presentes na pauta?

Qual modelo de pauta é adotado no Diário do Nordeste Plus?

Como são feitas as reuniões de pauta?

As características do tablet são levadas em conta na construção da pauta?

Há alguma avaliação de métricas no portal ou nas outras plataformas do grupo para a escolha do tema que será abordado na pauta?

Métricas de acesso às edições do Diário do Nordeste Plus influenciam nas temáticas escolhidas nas edições?

As mídias sociais tem algum influência na construção da pauta?

\section{Processo de Produção: Da apuração a edição do texto final}

Os repórteres vão a campo apurar ou cobrir eventos?

Quais as ferramentas são utilizadas para o processo produtivo da notícia?

Alguma base de dados é utilizada para produção da informação?

Por serem consumidas em um aparelho móvel, isso impacta de alguma forma a construção da informação? O repórter recebe alguma orientação neste sentido?

O fato de a interface da plataforma ser manuseada com os dedos é levado em consideração na produção da edição?

No fechamento da edição, há aproveitamento de conteúdos produzidos para outros suportes? Quais estratégias são adotadas?

Existe um planejamento prévio na arquitetura da informação? Em que momento esse planejamento é feito e quem é responsável?

Quais são os critérios utilizados para a construção do hipertexto?

Há uma preocupação com a interatividade do usuário?

Existe alguma previsão de uso de customização do conteúdo?

A memória é utilizada em algum momento da construção da informação? 
Há um tamanho aconselhado para a construção do texto?

Existe alguma orientação para o número de textos publicados em cada edição? Caso exista, quais são?

E a construção dos infográficos? Como é realizada a escolha dos temas e quais profissionais são responsáveis pela construção?

Como são escolhidos os arquivos multimidiáticos?

Há técnicas de edição para conteúdos multimidiáticos?

Existe um manual que orienta a edição do conteúdo?

Vocês seguem algum modelo para produção textual?

Existe alguma previsão para o uso de geolocalização na produção da informação?

Como são escolhidas as matérias que ganharão destaque na edição?

Qual horário de fechamento?

Qual a jornada de trabalho dos editores e repórteres?

Houve alguma mudança editorial na proposta inicial do Diário do Nordeste Plus?

O novo ritmo da redação, com sua prioridade para o digital, mudou alguma coisa na produção do Diário do Nordeste Plus?

Os editores do O Globo A Mais são responsáveis pela produção de outra plataforma?

\section{Convergência}

O fato de o $O$ Globo A Mais ter sua redação convergente traz alguma implicação no processo de produção da informação?

A partir de sua experiência profissional, você observa que existem transformações no processo de produção da notícia no contexto de uma redação convergente?

Você acredita que a produção de informação para o Globo A Mais impacta de alguma forma o processo de produção de outras plataformas?

Como conciliar e pensar a produção de uma edição de um jornal no contexto convergente?

Os reportes utilizam alguma base de dados para produção da edição?

O profissional: Colunistas, Repórteres e editores

Qual é a função do editor no Globo A Mais?

Existe alguma orientação aos colunistas para produzir conteúdo?

Como são escolhidos os colunistas?

Como são selecionados os repórteres?

Quais são as competências básicas para atuar como repórter? 
Elas passam por algum treinamento?

Precisa ter algum domínio de software ou ferramenta? Quais são?

Quais competências um editor multimídia precisa ter? 
APÊNDICE B: Formulário de entrevista com os repórteres de O Globo A Mais

\section{ROTEIRO}

Nome:

Tempo de profissão:

Formação e experiências profissionais:

\section{Parte: o profissional}

Qual é a função do repórter no Globo A Mais?

Quais competências você considera essências para atuar como repórter no Globo A Mais?

Quais ferramentas utiliza para produção da informação?

\section{Parte 2: Coleta: Pauta, fontes e apuração}

Repórter sugere pauta?

Como é feita a pauta?

Há uma preocupação com as características do suporte na construção da pauta?

Quais critérios utiliza para sugerir uma pauta?

Usa alguma ferramenta para apuração das informações?

As mídias sociais exercem alguma influência na construção da pauta e no processo de apuração?

Como é feita a apuração da informação?

Como os dados para produção das matérias são coletados e como essa coleta é dividida?

O fato de a interface da plataforma ser manuseada com os dedos é levado em consideração na produção da matéria?

Existe alguma orientação em produzir matérias multimidiáticas?

Além do texto, você produz outro formato?

Qual critério é utilizado para a produção de um formato de mídia em detrimento de outro?

Repórter produz gráficos ou infográficos? Quais critérios você utiliza para essa produção?

Quais critérios são utilizados na escolha das fontes?

O suporte é levado em consideração ao escolher alguma fonte?

Por ser um dispositivo móvel, é diferente produzir uma matéria para o suporte?

Usa alguma base de dados para produzir matérias? 
Na produção do conteúdo, são utilizados, de alguma forma, arquivos produzidos em outras edições?

Existe um planejamento prévio na arquitetura da informação? Quem faz esse planejamento?

\section{Parte 3: Edição}

Qual critério você utiliza para inserir o link na matéria?

Há uma preocupação com a interatividade do usuário com o conteúdo?

Há um tamanho aconselhado para a construção do texto?

Existe alguma orientação para o número de textos produzidos por dia? Caso exista, quais são?

Convergência

O fato de o Globo ter sua redação convergente traz alguma implicação no processo de produção da informação?

A partir de sua experiência profissional, você observa que existem transformações no processo de produção da notícia no contexto de uma redação convergente? 
APÊNDICE C: Formulário de entrevista com o editor de multimídia de O Globo A Mais

Qual é a função do editor multimídia?

Como surgem as demandas dos arquivos?

Quem produz os conteúdos multimídia?

Os conteúdos de outros suportes são aproveitados para o Globo A Mais?

As características do suporte influenciam de alguma forma na produção do conteúdo multimídia?

Por se tratar de um suporte que possui resolução em alta definição, há algum impacto na escolha das imagens?

Qual critério é utilizado para a produção de um formato em detrimento de outro?

Quem edita o material?

A redação possui seus próprios equipamentos para produção? Em caso positivo, quais são? 
Apêndice D - Entrevista com Repórter 1 de O Globo A Mais

Entreviatador: Uma pergunta um pouco óbvia, mas qual é a função do repórter no Globo A Mais?

Repórter 1: O repórter do Globo A Mais é responsável por desenvolver todas as pautas, ele sugere e a maioria delas são aceitas. Então, acho que tem essa vantagem de você fazer o que você gosta, sugerir as pautas que você quer, que eles vão comprar, e isso é uma coisa legal. E claro, as pautas que eles sugerem para a gente. Como toda relação, eu imagino, é uma via de mão dupla, você sugere e pautas são passadas para você. A função do repórter é essa, apurar as matérias, produzí-las, finalizá-las e pensar junto com o diagramador, o designer - eles não gostam de ser chamados diagramadores aqui - estruturação da matéria dentro do ambiente do tablet. Como a gente tem muita possibilidade de multimídia e inovação, você tem que fazer sua matéria e quando você já está entrevistando o cara você tem que pensar como aquilo vai render, vai estruturar, dentro do Globo Mais, nas questões multimídias e tudo mais, entendeu?

A: Quais são as competências que você acha que são necessárias pra se tornar repórter?

$\mathrm{M}$ : Eu acho que tanto no Globo A Mais, quanto no Globo são as mesmas competências, capacidade de apuração, bom texto, um texto próximo do final, responsabilidade, enfim, saber tratar bem essa questão social de circular direito. E é isso, apurar bem, ter boas fontes, boas ideias.

A: Quais são as ferramentas que você utiliza no seu dia-a-dia?

M: No Globo A Mais a gente usa muito o InDesign...Eu agora tenho...minha vida está no Google Drive, então eu uso todas as ferramentas do Google Drive para fazer tabela, editar texto, enfim, guardar contatos. Então basicamente a gente edita texto no Globo Drive, no documentos lá deles, e quando precisa passar para a fôrma, a gente usa o InDesign, da Adobe. Que eles desenham e a gente...

A: Quando você vai construir uma pauta você tem uma preocupação com as características do tablet?

M: É, claro, nem toda pauta pode ser... tem coisas maravilhosas para tablet, um recurso incrível. Mas o que vai dizer aqui dentro se a pauta é muito boa ou só boa, é como ela pode ser explorada dessa maneira multimídia. Pode ter raspadinha, quiz, enfim, o que diz se ela é muito boa são essas coisas, esse bônus multimídia.

A: Quais são os critérios que você utiliza pra sugerir uma pauta? 
M: Bom, a coisa tem que ser interessante, tem que ser noticias. Critério de habilidade básica. Tem que estar relacionado com alguma coisa de atualidade, noticia quente, ou uma coisa interessante que ninguém tenha dado ainda.

A: Você usa alguma ferramenta específica pra apurar as pautas?

M: Não, diferente das naturais não. Nas apurações eu vou usar gravador, telefone, bloquinho....nenhuma novidade.

A: Trabalha com alguma base de dados?

M: Não.

A: As redes sociais exercem alguma influência nas suas pautas?

M: Indiretamente sim, porque as redes sociais são mais uma maneira de filtrar informação do que acontece por ai. Gosto bastante de usar o Twitter e o Facebook, até para saber o que está acontecendo, quais são os assuntos mais comentados, o que as pessoas por ai estão comentando. E já aconteceu de surgir alguma coisa a partir disso.

A: Você tem alguma orientação em relação à tamanho do texto?

M: Não, não tem não. Bom senso, não pode ser muito pequeno, por mais que não tenha forma, não tenha limite, a gente sabe que também não pode ser muito grande porque o leitor não vai passar da metade. Então tem que ser uma coisa entre... É legal não ter limite, é legal você escrever sem ficar olhando ali a forma acabando e você pensando "poxa vida, falta ainda metade das coisas"... você bota tudo que tem de interessante ali, nem mais nem menos, entendeu? Isso é bom.

A: O que te leva a escolher um formato em detrimento do outro? Por que utilizar vídeo e não áudio?

M: Bom, também de novo é a pauta que pede, não sou eu que escolho. Uma pauta sobre que nem eu vi os meninos falando das pautas dos quadrinhos, que eles desenhavam de olhos fechados, era muito interessante ter o quadrinista vendado desenhado isso, porque é lúdico ver o cara com a venda nos olhos, desenhando. Então, essa era uma pauta que pedia vídeo. Essa que estou fazendo hoje sobre bandas de rock, ela pede áudio, ela basicamente é uma pauta que o enriquecimento dela são as músicas das bandas, é isso.

A: Existem fontes que são mais adequadas pra utilização do suporte ou não é diferente?

M: Não entendi muito bem a pergunta, mas acho que não.

A: É no sentido de que ao escolher uma fonte, por exemplo uma banda, essa banda ela possui características que vão potencializar o uso dela?

M: (7:00 - 7:06s - Está confuso) Não tem enriquecimento, eu acho que não deu pra 
pauta, não, a gente vai encontrar a partir do que a gente tem, nem que seja uma foto galeria que tenha um enriquecimento mais, na minha opinião, pobre, né, é mais básico.

A: Por ser um dispositivo móvel, isso transforma a matéria, você observa que tem características diferentes?

M: Sim, acho que sim. Porque, não sei, talvez não seja por ser um dispositivo móvel, mas o Globo A Mais é diferente do que é produzido no site e no papel, entendeu? Não sei te dizer se porque é um dispositivo móvel, mas o que é produzido aqui é diferente do que é produzido nos outros lugares.

A: Qual critério você utiliza pra inserir link na matéria?

M: Quando é necessário, se eu falo de um site, "site x faz isso isso e aquilo", é muito melhor do que dizer, você também vai dizer, é claro, mas você vai linkar para a pessoa, se ela tiver curiosidade. Uma coisa que eu, engraçado né, no jornal você sente falta disso. Por mais que tenha aquele hiperlink que você nunca vai precisar, seria muito melhor, e o Globo A Mais faz isso. A versão em flip do jornal já faz um pouco, é linkar e dizer "ó fulano disse isso", então você acessa o site, acessa esse link, ouve aquilo.

A: Existe alguma preocupação com interatividade ao produzir a matéria?

M: Bom, interatividade é você também ter o retorno do que o leitor faz, não. Posso dizer que não.

A: É, quando eu falo interatividade eu to falando também no aspecto qualidade, como navegar seria uma alternativa, então pensar em recursos seria uma alternativa interativa.

M: Sim, aí eu posso dizer que sim.

A: O fato do Globo A Mais estar dentro de uma redação convergente trás alguma implicação no processo de produção da notícia pra você como repórter?

M: Talvez, no mundo ideal, o site e o jornal conversarem mais, nos dá uma abertura maior pra gente apurar um assunto, sair do jornal e irem por outros caminhos. Mas como o processo de convergência ainda está sendo implantado, ainda existe muita dor de cabeça. Mas, sim, sim, o fato do jornal estar convergente, significa que ele está pensando pro mesmo lugar então as coisas ficam mais bem divididas.

A: A gente observa algumas transformações no processo de produção da informação, e aí eu falo nesse contexto convergente mesmo...

M: É difícil eu observar muitas transformações porque como eu te disse, cheguei aqui ano passado, a minha experiência é pouca. Eu acredito que as coisas estão se transformando e tal, mas eu não sou a pessoa mais capacitada para estar captando ela toda. 
Apêndice E - entrevista com Repórter 2 de O Globo A Mais

Entrevistador: Qual é a função do repórter no Globo A Mais?

Repórter: A função do repórter no Globo A Mais é uma função kamikaze, eu diria, em primeiro lugar, porque pra começar é o contrário de todas as editorias dos outros jornais, a gente aqui não tem um foco específico, não é como na economia em que o repórter vai cuidar só de economia, no nacional que ele vai olhar política, enfim, na internacional que ele está de olho, é kamikaze porque a gente está de olho em tudo, a gente é revista então tudo é pauta. E eu diria que essa é a dor e delícia de você fazer um produto como o Globo A Mais, que por um lado te dá uma experiência de ter uma liberdade absurda, no meu caso, por exemplo, uma pessoa que sempre foi de internacional, eu sai do internacional, mas não abandonei o noticiário internacional, faço matérias de internacional aqui, mas de repente eu estou fazendo uma matéria sobre a igreja Universal essa semana, e de repente um negócio sobre arquitetura, e isso é maravilhoso porque o céu é o limite. Mas tem um lado mais difícil, quando eu estou, por exemplo, buscando pautas, de olho em ideias, você se perde um pouco, é uma coisa louca, não tem mais nenhum setor onde eu possa dizer "sou especialista nisso, acompanho com afinco isso", não, eu acompanho um pouquinho de tudo, o que eu acho que vá mais ou menos, não sei, na contramão do que está todo mundo fazendo, diante dessa overdose de informação acho que as pessoas estão tentando se especializar e aqui não, a gente flutua.

A: Quais são as competências que você acha necessárias para assumir a sua função aqui no Globo A Mais?

R: Eu acho que não é diferente de outros lugares, você tem que ter um olhar apurado, entender o que é notícia, o que é importante, estar bem informado sobre o neofactual, todas as editorias, que é o que eu disse que é a parte mais difícil porque não se limita a um assunto só, você tem que ter uma visão muito global. Saber escrever, saber apurar, e claro, a dificuldade específica do Globo A Mais é você pensar além do texto, que pra mim é uma dificuldade muito grande às vezes, com o meu background internacional às vezes eu vejo uma matéria com uma análise incrível, mas é aquele velho problema de você ter que adequar o seu material à plataforma, um material que talvez fosse incrível em um jornal impresso, mas que talvez no iPad, no tablet ficasse muito chato de ler porque é muito texto, é muita análise.

A: Isso você acha que inviabiliza a publicação de um assunto?

R: Não, aqui no nosso caso não, mas a gente perde um pouco mais de tempo quebrando a cabeça pensando numa maneira de tornar aquilo um pouco mais interativo. Eu vi um especialista que elabora umas perguntas fazendo um quiz sobre, não sei, "o que você sabe 
sobre Casa Branca?", enfim, de alguma maneira é uma preocupação constante que a gente tem aqui, de não oferecer só uma coisa que tem no jornal de papel, que seja interativo, que seja clicável.

A: Quais são as ferramentas que você utiliza no seu dia-a-dia, como repórter? Ferramenta bem ampla, software, há uma diferença?

R: Não, nenhuma, internet, meu maior amigo é o Google Chrome, é o Google, acho que é o melhor amigo de todos nós, enfim, temos aqui de publicação, acho que você deve ter visto, a gente usa o Windesigner, a gente usa alguns programas de armazenamento de fotos, do jornal, digicall, mas não é nada, nesse ponto eu não acho que seja nada muito diferente que os meus colegas em outras editorias usam.

A: O repórter sugere pauta?

R: Sim, o tempo inteiro.

A: E por ser pra um dispositivo móvel isso vai alterar essa pauta?

R: Não, isso não altera a pauta, mas isso altera a forma de você apresentar essa pauta, isso altera muito.

A: E você tem essa preocupação na hora em que você vai sugerir a pauta?

R: Sem dúvida. O que não é fácil, até porque nesse momento de transição a maioria de nós, a gente tende a pensar mesmo com a cabeça do jornal, a gente pensa em texto, e nesse caso não, a gente precisa pensar em foto, a gente precisa pensar em vídeo, em áudio, a gente precisa pensar em uma série de coisas que é uma novidade pra todo mundo.

A: E quais são os critérios que você utiliza para sugerir essa pauta?

R: Assim, é aquela velha história, depende muito, são coisas que eu acho interessantes, naveguei, vi um negócio, enfim, depende, depende também do tipo de pauta, se é uma coisa mais factual, por exemplo, tem uma crise rolando na Síria, o avanço do estado islâmico, eu sou uma pessoa que acompanha esses assuntos, paixão pessoal, e uma análise num jornal americano, "pô, isso aqui é legal, vou ligar pra uns especialistas, conferir se é isso mesmo", enfim, a partir daí eu procuro criar uma análise que satisfaça a curiosidade, os interesses do nosso leitor do Brasil, porque a Síria está muito longe lá, não tem nada a ver com a gente. É uma coisa de comportamento, esses dias sem querer no Facebook, navegando, funçando no Facebook alheio, uns amigos libaneses tinha postado fotos de um projeto do Niemeyer esquecido no Líbano, "vem cá, que coisa incrível, Niemeyer no Líbano?”, eu fui procurar, liguei pra fundação Niemeyer, fizemos uma matéria super legal com as fotos do projeto, como está abandonado, então assim, depende muito.

A: Você já me falou mais ou menos, mas as mídias sociais exercem alguma influência 
na construção dessa pauta?

R: Sim, com certeza, é uma fonte infindável, a gente tenta estar de olho em tudo, às vezes a melhor idéia, o melhor insight está na mesa do bar, a mesa do bar pra gente hoje em dia é o Facebook, é o Twitter.

A: Existe alguma orientação quando você entra na produção dessas matérias multimidiáticas?

$\mathrm{R}$ : Como assim?

A: Com vários formatos, você é recente, você entrou há pouco tempo aqui, mas existe uma orientação no processo de produção delas? Você só faz texto, mas você também tem que escrever em novos formatos, criar narrativas.

R: Sim, essa é uma orientação básica, não é uma determinação, ninguém me chamou e falou "olha, tem que ser assim", mas eu acho que todo mundo que vem para um projeto como este precisa ter isso na cabeça, né. Essa interação com o tablet é muito diferente da interação com o papel, você quer clicar, você quer ver uma foto, você quer ver um vídeo sem sair dali, sem ir em outra janela, então você precisa pensar nisso.

A: Quando você produz o texto, tem alguma preocupação com o formato? Formato que eu digo, pirâmide invertida ou qualquer coisa do gênero?

R: Não, nada que eu não fizesse antes no papel, nesse sentido não. É aquilo que obviamente estando numa revista e sem limitação de espaço, que é um diferencial, é muito mais agradável escrever, porque não tem uma forminha ali de poucos centímetros que eu tenho que contar uma história, às vezes enorme, naquele espaço determinado, aqui o céu é o limite. É óbvio que eu não vou escrever um milhão de quilômetros de texto que ninguém vai ler, mas é muito bom isso porque me dá liberdade criativa mesmo de sair daquele formato cru, e de criar, de fazer, enfim, não vou dizer que é uma licença poética, o jornalismo é um texto reportagem, uma coisa mais trabalhada, isso é muito legal.

A: Qual é o critério que você utiliza para escolher um formato em detrimento do outro, por exemplo, eu vou usar vídeo em vez de usar áudio, eu quero utilizar a foto.

R: Olha, hoje em dia eu diria que infelizmente são as circunstâncias mesmo. É óbvio que a gente gostaria de fazer todas as matérias com vídeo, com foto, com tudo, a gente queria oferecer tudo, mas existem limitações naturais de recurso, então isso é um pouco decidido conforme aquilo que se tem. Agora, obviamente, se você tiver uma matéria incrível e não tiver uma foto, ou um vídeo, você vai buscar uma maneira de ilustrar aquilo, não vai deixar de publicar porque você não tem, isso é uma preocupação extra. Mas são as circunstâncias, agora, por exemplo, a matéria da Universal, foi uma dificuldade porque você não pode sair 
tirando foto dentro da igreja sem chamar atenção, a gente fez com muita dificuldade, com celular, baixinho e etc, a gente fez alguns trechos de vídeos dos momentos em que os pastores pedem dinheiro, etc, a qualidade é fenomenal? Não é, mas é o que a gente vai usar porque foi o que a gente conseguiu.

A: Uma fonte deixaria de entrar numa matéria, uma limitação, por exemplo, essa fonte seria ideal eu utilizar um vídeo dela, eu teria que ter um áudio, ela deixaria de entrar no conteúdo da sua matéria por causa de uma ausência de um formato específico?

R: Não, de maneira nenhuma, ainda mais se ela for parte importante pra você contar uma história, a gente vai fazer, a gente não vai deixar de publicar por causa dessa ausência de elementos, mas essa é uma preocupação constante. A gente já teve casos aqui no Globo A Mais, agora eu não consigo lembrar, mas que era alguma coisa que a gente não tinha uma foto incrível pra capa, a gente foi lá na arte e pedimos pros nossos ilustradores para fazer uma ilustração, os designers animaram aquela ilustração, então você tem que ter criatividade para encontrar uma saída, mas deixar de publicar não.

A: Como é que se decide, "ah, eu resolvi fazer um infográfico", de quem é essa iniciativa? De quem surgem essas idéias?

R: É aquela coisa, vai muito do repórter, mas uma coisa legal é que a gente trabalho muito em conjunto, então as vezes ta com uma dificuldade, daí pergunta pro lado, porque às vezes você está tão focado ali na apuração, no texto, que você não está mais com cabeça pra pensar na firula, então a gente troca muito idéias, o tempo inteiro, "o que você acha?", a gente pergunta pros designers, "vocês conseguem?", porque eles tem essa visão, às vezes, muito melhor do que a gente, então essa interação é constante, é realmente uma troca.

A: Vou ter que voltar e perguntar de novo, mas existem fontes que são mais adequadas para se produzir uma matéria para tablet? Por ser tablet tem uma fonte que é mais adequada?

R: Não, a mesma coisa. Isso independe do meio, o que a gente busca é contar história de qualidade, enfim, histórias bem apuradas, bem sedimentadas, bem embasadas, independe do meio.

A: E por ser um dispositivo móvel, é diferente fazer matérias para esse produto?

R: Olha, vou te falar de maneira geral, porque depende do aplicativo, depende da proposta, no caso do Globo A Mais, sim, porque é aquela coisa, o Globo A Mais, como o próprio nome diz, é o Globo a mais, é além, então a gente tenta contar histórias que não teriam espaço no papel, a gente tenta, se vai fazer alguma coisa ligada ao factual, a gente busca uma outra visão, uma visão mais analítica, então é diferente nesse sentido, vários assuntos mais fundo do que você iria no papel, por exemplo. 
A: Você utiliza alguma base de dados para produzir esse conteúdo, específico?

R: Não de maneira sistemática, se eu estou procurando uma informação específica aí eu vou procurar encontrar alguma coisa que me ajude nesse propósito.

A: Utiliza de alguma forma a memória do que já foi produzido, as memórias do Globo A Mais?

$\mathrm{R}$ : Nosso próprio material?

A: Isso.

R: Não, acho que não.

A: Você tem alguma preocupação com a arquitetura da informação, arquitetura no sentido, "olha, eu vou planejar aqui, o vídeo fica aqui, o áudio aqui”?

R: Sim.

A: Em que momento você pensa isso?

$\mathrm{R}$ : Isso depois que a matéria está riscada, que os designers desenharam, porque eles vão tratar dessa parte prática, eles não sabem o que tem no texto, então eles colocam lá, aí depois eu vejo que num determinado momento que eu to falando, sei lá, o caso da Universal de novo porque está fresco na cabeça, de como os grandes templos hoje estão vazios, se eu tenho um infográfico falando disso lá embaixo, eu vou pedir para colocarem mais pra cima, então você vai tentando colocar aquelas coisas numa sequência lógica.

A: Qual critério você utiliza para inserir links na matéria?

R: A gente insere muito pouco link aqui, essa é uma boa pergunta, normalmente a gente no Globo A Mais insere link só quando é dica, que a gente tem uma sessão de dicas culturais, "veja a programação no site", "confira", mas normalmente nas matérias não. Inclusive, se a gente tem outras informações, acho que é uma estratégia muito comum, não que seja pensado, no meu caso pelo menos nunca foi, mas eu tento trazer esse conteúdo pra dentro e não colocar pro cara clicar pra ele sair do meu aplicativo, acho que no fundo a lógica é essa, você tentar segurar o leitor no nosso ambiente.

A: Há uma preocupação com interatividade com o usuário quando você produz a sua matéria?

R: Sim,o tempo inteiro, que é a questão que eu disse de como produzir um áudio, como produzir um vídeo, como produzir um passa-fotos, enfim, coisas que sejam clicáveis, que estimulem o cara a "ué, mas o que tem aqui? Vou tocar e vai aparecer o que aqui?", a gente tenta trabalhar um pouco esse fator surpresa.

A: Como você já trabalha aqui há algum tempo eu acho que essa é uma pergunta que vai estar mais clara pra você, o falo da redação do Globo A Mais estar dentro de uma redação 
convergente, isso impacta de alguma forma na maneira de você produzir o seu conteúdo?

R: Não, eu não sei o que as outras pessoas falaram, mas isso é um tema de debate constante, na verdade nós somos um veículo dentro do veículo. Enfim, esse é um debate que eu acho que a gente não tem muitas respostas, porque a gente questiona muito se seria interessante a gente trazer a expertise de pessoas que estão, aquela coisa que eu disse, que estão focadas na economia, que estão focadas na política, que pudessem trazer esse conhecimento pra gente, ou se essa separação não deve existir, são perguntas que a gente faz aqui diariamente e a gente ainda não tem resposta.

A: Então você sente que está separa, que não faz parte dessa integração?

$\mathrm{R}$ : Eu acho que sim, porque nós temos um fluxo de trabalho muito diferente, muito diferente, o que não necessariamente é ruim, é aquela coisa, aqui eu não tenho aquela obrigação de um fechamento factual, que aconteceu agora, por ser revista a gente tem essa liberdade.

A: E você observa que existe transformação no processo de produção da notícia nesse contexto em que você se encontra?

R: No Globo A Mais ou em geral?

A: No Globo A Mais.

R: Não mudanças no processo de processo, não acho que é isso, mas é aquela forma, a gente tenta pensar qual é o papel de um produto como o Globo A Mais, é uma coisa que todo mundo está pensando, a gente tenta descobrir o que que o leitor espera da gente, a gente tenta fugir do óbvio, o que nem sempre é uma tarefa fácil, por exemplo o dia que caiu o avião do Eduardo Campos, loucura, caos, pandemônio, sendo que o jornal, o site, não tem guideline, as coisas vão acontecendo e sendo produzidas, enfim, o papel tem até $22 \mathrm{~h}$, num caso drástico desse se for o caso você pode estender pra fechar, a gente tinha que ter uma edição pronta para colocar no ar às $18 \mathrm{~h}$, como lidar com isso? Num caso como esse não fazia nenhum sentido você ter uma matéria de capa, a gente derrubou a matéria de capa do dia, obviamente, mas como entrar nesse assunto, que fosse alguma coisa relevante, que o site não estivesse dando, e que fosse viável, porque o tempo era muito curto. Enfim, são os desafios diários. 
Apêndice F - entrevista com Repórter 3 de O Globo A Mais

Entrevistador: Qual é a função do repórter no Globo A Mais?

Repórter 3: Bom, acho que a nossa função é ficar muito atento ao que acontece, em várias editorias diferentes. Tentar pensar em pautas, não factuais, mas que além disso tenham uma possibilidade de uma abordagem multimídia. Acho que essa é nossa principal função. Fora assim, a gente tem algumas tarefas cotidianas como giro, mas como reportagem, essa é a nossa função até pra traduzir o noticiário na plataforma multimídia.

Entrevistador: Quais são as competências que você acha necessárias para assumir a sua função aqui no Globo A Mais?

R3: Olha, assim, eu acho que tem que ser isso, mesmo que seja uma pessoa que venha de uma editoria, que tenha uma função dentro de uma estrutura especifica, tem que ser alguém com olhar muito aberto para vários assuntos já que a gente não tem definição de "esse dia tem que ser economia e tal". E eu acho que a gente tem que sempre tentar encontrar o outro lado da história, um lado que o jornal não vai abordar, porque cada vez o jornal está sendo menos factual também, mas a gente, além disso, tem que encontrar outro jeito de contar essa história.

Entrevistador: Quais são as ferramentas que você utiliza no seu dia-a-dia, como repórter? Ferramenta bem ampla, software, há uma diferença?

R3: Nossa ferramenta principal é o InDesign. Tudo que ele possibilita fazer tem um impacto na nossa produção. A gente teve uma mudança de programa, a gente já usou outros programas também. E quando veio o InDesgin, isso mudou a forma da gente pensar o produto, o que a gente podia fazer dentro disso. Até questão de ampliação das plataformas mesmo, o fato de a gente hoje estar publicando no Iphone, Android, e a forma como o InDesgin faz isso, também impacta no nosso trabalho. O tempo a mais que a gente tem que fazer, o que que isso possibilita...o enriquecimento que a gente dá para o Ipad, se pode ir para o Android ou não.

Entrevistador: O repórter sugere pauta? E por ser pra um dispositivo móvel isso vai alterar essa pauta?

R3: Totalmente. Assim, o jornal tem um site, tem uma produção diária. Então, a gente tem que pensar em matérias que sejam para o tablet, que é inclusive nosso principal produto, apesar de a gente ter também até essa transferência para o Iphone, o tablet é o nosso principal, o carro chefe, Ipad principalmente. Então, assim, as pautas são pensadas para estarem ali e não em outro lugar. 
Entrevistador: E você tem essa preocupação na hora em que você vai sugerir a pauta?

R3: Acabo indo um pouco pela minha trajetória profissional. Acabo sugerindo pautas de internacional, política e Rio. Mas assim, eu também estou muito atenta ao que está acontecendo, alguma notícia quente que possa render alguma outra...uma matéria. Eu não restrinjo muito não, comecei a fazer matéria de economia, rede cultura...enfim.

Entrevistador: E quais são os critérios que você utiliza para sugerir essa pauta?

R3: Todas que estejam disponíveis. Internet, claro. Redes sociais, enfim, telefone, banco de dados.

Entrevistador: Você já me falou mais ou menos, mas as mídias sociais exercem alguma influência na construção dessa pauta?

R3: Sim, com certeza, porque tem noticia que surge de lá, ou repercute por lá, depois...A gente tem site web, mas quando nossa matéria vai para o site mesmo e gera o link, isso também gera um retorno. Então, assim, não só na produção e surgimento de pautas, mas acho que também como feedback e ter uma noção do que que rende.

Entrevistador: Existe alguma orientação quando você entra na produção dessas matérias multimidiáticas?

R3: Sim. O que a gente chama de enriquecimento aqui, acho que seria isso que você está falando. Nossas matérias não podem ser só texto. A gente tem que trabalhar com essas outras formas de comunicação, seja foto, vídeo ou gamer.

Entrevistador: Quando você produz o texto, tem alguma preocupação com o formato? Formato que eu digo, pirâmide invertida ou qualquer coisa do gênero?

R3: Acho que o que mais de adequa à matéria e o que a gente tem possibilidade de fazer naquele momento. Ou seja, porque a pauta não permite, por questão de logística ou por uma questão de jornal mesmo, de produção.

Entrevistador: Qual é o critério que você utiliza para escolher um formato em detrimento do outro, por exemplo, eu vou usar vídeo em vez de usar áudio, eu quero utilizar a foto.

R3: O infográfico a gente executa junto com o designer também. Tem vezes que vamos para a rua, sem fotógrafo, já fiz vídeo também, Estamos abertos para outros formatos, também.

Entrevistador: Uma fonte deixaria de entrar numa matéria, uma limitação, por exemplo, essa fonte seria ideal eu utilizar um vídeo dela, eu teria que ter um áudio, ela deixaria de entrar no conteúdo da sua matéria por causa de uma ausência de um formato específico? 
R3: Não, acho que a fonte vai se adequar à matéria, não ao dispositivo. Vou procurar quem for mais adequado, tanto pessoa quanto dados, para minha matéria. O dispositivo não tem muita relação com isso.

Entrevistador: Como é que se decide, "ah, eu resolvi fazer um infográfico", de quem é essa iniciativa? De quem surgem essas idéias?

R3: Sim, a gente usa muito isso aqui assim. Nessa matéria agora que a gente está fazendo dos evangélicos, a gente falou "ah, vamos fazer com o enriquecimento que a gente usou no lixão imperial", que foi de um colega nosso, que até já saiu. Então, essa memória do que a gente já usou de enriquecimento, a gente nem pega matéria e partir disso constrói, mas o fato de já ter usado esse jogo, gamer, ou qualquer recurso, serve de base para a gente montar outra reportagem.

Entrevistador: Vou ter que voltar e perguntar de novo, mas existem fontes que são mais adequadas para se produzir uma matéria para tablet? Por ser tablet tem uma fonte que é mais adequada?

R3: Nesse sentido sim, porque eu tenho que saber o que vai entrar no enriquecimento multimídia e no meu texto, para não se sobreporem. A gente tenta sempre trazer o enriquecimento como uma coisa a mais.

Então, além assim, de uma estrutura de texto ** tem que pensar o que vai para cada recurso que eu escolhi.

Maioria das vezes, isso está mais ou menos desenhado na hora que a pauta se define e a gente propõe já um enriquecimento. Mas isso vai, na verdade, sendo mais apurado, quando eu tenho as informações apuradas. Ai eu falo assim "Olha, eu tenho esses dados. E acho que esses dados vão ser melhor usados se tiverem um infográfico" ou então "Não, é melhor usar dentro do texto, porque é fundamental para pessoa que está lendo, ter entendimento"

Entrevistador: E por ser um dispositivo móvel, é diferente fazer matérias para esse produto?

Entrevistador: Qual critério você utiliza para inserir links na matéria?

Entrevistador: Você tem alguma preocupação com a arquitetura da informação, arquitetura no sentido, “olha, eu vou planejar aqui, o vídeo fica aqui, o áudio aqui”?

Entrevistador: Em que momento você pensa isso?

R3: Quando é um vídeo que vale muito a pena ser baixado e o tamanho não é tão grande, eu acho melhor que usar o link. Mas sempre que tem a possibilidade a gente usa, porque já que é um tablet, é importante usar.

Entrevistador: Você utiliza alguma base de dados para produzir esse conteúdo, 
específico?

R3: Como eu estava falando, acho que nossas matérias não podem ser pensadas sem serem interativas. E já não basta mais serem só foto-galeria. A gente tenta pensar em coisas que estimulem o leitor.

Entrevistador: Utiliza de alguma forma a memória do que já foi produzido, as memórias do Globo A Mais?

R3: Não, essa é a parte boa. O aconselhável é “escrevam reportagens longas”, já que é um produto, que é uma leitura a mais, que as pessoas, teoricamente, podem usar nos tempos livres. Então geralmente são textos mais longos, então a gente tem bastante liberdade quanto a isso.

Entrevistador: Há uma preocupação com interatividade com o usuário quando você produz a sua matéria?

R3: A gente não trabalha muito como site, que tem que subir várias matérias. Então, geralmente, a gente está produzindo uma matéria, normalmente uma ou duas por semanas, como fossem dominicais. A gente divide, a produção de giro, pegar uma vez na semana, mas não tem uma cota ou nada do tipo.

Entrevistador: Como você já trabalha aqui há algum tempo eu acho que essa é uma pergunta que vai estar mais clara pra você, o falo da redação do Globo A Mais estar dentro de uma redação convergente, isso impacta de alguma forma na maneira de você produzir o seu conteúdo?

R3: Totalmente, a gente tem outras pessoas produzindo informação, que muitas vezes concorrem com o que a gente também está querendo falar. E a gente tem que arrumar um jeito de conciliar isso e também trazer coisas diferentes, então, faz muita diferença.

Entrevistador: Então você sente que está separa, que não faz parte dessa integração?

R3: Sim. Principalmente, desde o início, o jornal era mais factual, então a gente sempre conseguiu entrar em um assunto quente, indo por um lado não factual, e a gente entrava bem. Agora o jornal está mudando, o jornal também está se tornando mais flexível, com matérias mais bem elaboradas. Não elaboradas, sempre tinham matérias elaboradas, mas que tentem ir além do factual. Então, tem mudado nosso processo. A gente tem que, além de fugir do factual, tem que trazer a informação mais adequada para o dispositivo que a gente está usando.

Entrevistador: E você observa que existe transformação no processo de produção da notícia nesse contexto em que você se encontra?

R3: Acho que sim. Como a gente tem decisão em uma grande cobertura do que que 
vai para o papel, o que vai para o site, e o que vai para o tablet, é porque a informação que está aqui tem que ser adequada pra cá. Se for dizer que critério é esse... Acho que geralmente é que propõe uma reflexão maior, é o que tem espaço para uma reportagem mais longa, assim, mais interativa, é difícil dizer porque depende muito do que é o contexto, do que é o assunto. 
Apêndice G - entrevista com Repórter 4 de O Globo A Mais

Entrevistador: Certo. Qual a função do repórter do Globo A Mais?

Repórter: A gente tem que procurar pautas, os nossos chefes dão algumas pautas pra gente, mas a maioria das pautas somos nós que buscamos, apurar pauta, obviamente. Às vezes a gente faz foto, vídeo, dependendo de como for a situação, sempre pensando em algum elemento multimídia, sempre pensando em alguma interatividade. Nossa função não é só apurar e bater o texto, mas pensar na foto, se vai ter um infográfico, se vai ter um mapa, se vai ter um vídeo, uma coisa assim.

E: Quais competências você acha que são essenciais pra ser repórter do Globo A Mais?

R: Tem que ter uma visão mais aberta. Normalmente quando acontece de algum colega estar de férias e vir alguém do impresso, principalmente, pra substituir aqui e uma coisa que eu vejo que os colegas do impresso ficam um pouco atônitos é com essa riqueza de elementos que a gente precisa pensar além do texto e uma foto só. Porque aqui nunca é só um texto e uma foto, é sempre um texto, uma foto, um vídeo, um áudio, um infográfico, tem que sempre pensar em mais coisas.

E: Geralmente quais são as ferramentas que você utiliza? E aí eu to perguntando sobre ferramentas em um leque bem amplo, você edita um áudio, você precisa utilizar um equipamento específico?

B: Quando a gente vai fazer um vídeo, se é um vídeo pensado, elaborado, a gente conversa com a fotografia, normalmente vai um fotógrafo que tem habilidade também de fazer vídeo e o fotógrafo faz o vídeo, filme, e tem uma equipe de edição, que edita os vídeos pra gente. Eu nem tenho aqui nenhum programa de edição, se eu tivesse eu até poderia, eu sei editar vídeo, mas normalmente tem uma equipe específica que faz essa edição. A gente usa muito o celular, eu uso muito o meu próprio celular, o meu iPhone, ontem, por exemplo, eu fui num culto de uma igreja, e eu fui lá e fiz um videozinho, fiz foto que a gente vai usar na matéria.

E: Há preocupação com as características do Tablet na hora da produção da pauta? Você tem essa informação?

R: Acho que a preocupação, tem uma preocupação em ter boas imagens, a gente já teve alguns problemas de pautas muito boas, mas que não tinham imagens legais, e aí a pauta acaba perdendo um pouco da sua força. Porque o tablet é muito visual, então é legal a gente ter pautas principalmente que tenham imagens boas, fotos boas, se render um vídeo bom, 
melhor ainda. E tem a preocupação em ter essa interatividade, em ter algum elemento que o usuário possa brincar, possa tocar, coisas que abram e fecham, ter algum tipo de interação com o leitor.

E: E quais são os critérios que você utiliza pra dizer "esse tema eu posso propor porque eu sei que isso vai gerar interesse"?

R: Não tem critério, aqui é a maravilha e o desespero de poder falar de absolutamente tudo. Uma das questões quando eu comecei a trabalhar aqui é justamente que o meu campo é tão aberto que eu nem sei em que focar, com o tempo você vai procurando aqueles assuntos que te interessam mais, acaba identificando quais são as pautas que te interessam e que funcionam bem aqui no Globo A Mais, mas você tem liberdade pra pensar qualquer coisa.

E: Você utiliza alguma ferramenta pra apurar a informação?

R: Internet. Quando é alguma pauta, eu gosto muito de mexer com dados, então eu uso muito o Excel pra fazer conta, pra fazer planilhas e tal, mas onde eu mais encontro pautas é nas redes sociais, eu uso muito as redes sociais pra procurar pauta, ver algumas tendências, ver de repente...

\section{E: Apura também?}

R: Sim, demais. Eu fico demais, hoje eu não estou porque estou batendo texto, mas eu fico direto com o Facebook aberto, Twitter aberto.

A: Existe alguma orientação de que vocês tem que produzir matérias multimidiáticas?

B: Como assim midiáticas?

A: Multimidiáticas, em vários formatos.

B: Não é nenhuma orientação, é uma obrigação.

A: E em relação à tamanho de texto, há alguma orientação?

B: Não, tamanho é livre, eu procuro não fazer textos muito longos porque eu acho cansativo, mas um texto não muito longo pra mim é um texto enorme pro jornal.

A: E em relação à formato, à critério, você, por exemplo, “ah, eu utilizo a pirâmide invertida pra construir meus textos", você tem algum tipo de preocupação em relação à isso?

B: Não. O formato acho que cada repórter tem o seu jeito de escrever.

A: E qual é o critério que vocês utilizam pra dizer assim, "aqui eu vou utilizar um vídeo", "aqui eu vou utilizar um halo"?

B: Vai muito do que você encontra durante a sua apuração, eu sempre prefiro vídeo, porque eu acho que como o tablet tem essa característica de ser muito visual, eu acho que o vídeo acaba sendo mais interessante pro leito. Mas, por exemplo, eu fiz uma matéria deve ter uns dois meses, mais ou menos, que era sobre o músico indígena, eu nem tinha a disposição 
um vídeo, porque tinha sido uma pesquisadora que tinha só gravado os áudios, eu até tinha vídeos, mas os áudios eram mais interessantes, então a gente colocou os áudios.

A: Quando produzir um infográfico ou gráfico? Quem propõe isso entre vocês?

B: A gente que pensa, conversa com os diagramadores, durante a apuração você está sempre procurando dados que possam ser interessantes, e normalmente, eu gosto muito de trabalhar com infográficos, acho que fica bacana. E aí, normalmente, eu converso com o diagramador, "oh, tenho esses dados, o que a gente pode fazer?", e aí a gente bola juntos, se vai ser um mapa interativo, se vai ser um gráfico, o que vai ser.

A: Você acha que existem fontes melhores para se utilizar no tablet, tem uma fonte que é mais adequada ou não?

B: Fonte de que sentido?

A: Fonte, uma fonte pra minha matéria.

B: Fonte você diz base de dados?

A: Não, um entrevistado, claro que to falando de fontes num sentido mais amplo, não só de uma fonte oficial, pessoa, mas eu to falando também de uma base, alguma coisa. Você acha que existem fontes mais adequadas para se utilizar numa matéria?

$\mathrm{B}$ : Eu acho que a fonte adequada pro jornalismo independente do formato, né.

A: Por ser dispositivo móvel, é diferente produzir uma matéria pra esse suporte?

B: Não é diferente produzir, mas é diferente pensar, porque como eu disse você tem que ter um pensamento um pouco mais amplo, um pouco mais aberto. Você sabe que só um texto escrito e uma foto não vão suprir, vão suprir a necessidade do seu leito, claro, mas a gente está aqui sempre querendo surpreender o leitor. $\mathrm{O}$ meu objetivo quando eu faço uma matéria é que o leitor veja e fale "poxa, olha que legal, que interessante isso", e se divirta também ali, se divirta que eu digo assim, tenha prazer ali de explorar aqueles dados, aquelas informações.

A: Em março, mais ou menos, aconteceu uma transição digital (10:14s), acho que você deve ter acompanhado. Nesse processo de produção vocês acabam utilizando algum produto ou algum material de uma outra edição?

B: A gente usa muito, não sei se você já viu, o Giro, a primeira sessão do Globo A Mais é o Giro de notícias, e cada dia da semana é um repórter que faz o Giro, e a gente usa muito as informações do site, principalmente as informações do site do Globo. Quando eu estou fazendo o Giro eu olho também as informações que estão saindo nos outros sites, mas uso muito as informações do site do Globo. E outra coisa que às vezes é interessante, esses dias mesmo eu estava usando, é o acervo do Globo, o acervo digital, a gente tem o acervo 
interno, que a gente usa, que é um banco de dados aqui do jornal, mas às vezes eu acabo pesquisando no próprio acervo on line.

A: Dá pra pesquisar nesse banco de dados do jornal?

B: Sim.

A: Então eles não usam, você é a primeira que diz que usa.

B: Mas, espera aí, qual base de dados?

A: A base de dados do jornal, aqui todo mundo tem acesso, né?

B: O digicall (Não sei se é este nome mesmo)?

A: É, eu acho que sim, eu não sei o nome não, ninguém me falou o nome não, você que está me falando agora, mas também eu não entrevistei repórter.

B: É, sempre que eu vou fazer uma matéria, por exemplo, eu estou fazendo uma matéria agora sobre a Universal, eu vou nesse, não é um banco de dados...

A: É uma base de dados das produções...

B: De tudo o que já foi produzido no jornal...

A: É uma memória.

B: É, uma memória do jornal, então eu procuro lá, escrevo "igreja Universal” e vejo tudo o que já escreveram sobre a igreja Universal, em primeiro lugar pra ver se a minha pauta é válida, se ela já não foi feita, segundo pra ver o que já saiu, porque eu posso pegar informações que estavam ali até pra dar mais riqueza pra minha matéria.

A: Quando você pensa na matéria você pensa na arquitetura da informação? Arquitetura no sentido da hierarquia, como é que essas informações vão estar casadas? Tipo, eu tenho um vídeo, eu tenho um áudio, você pensa em como vai estruturar esse conteúdo?

B: Penso, penso tanto na estrutura do texto, o que eu vou começar, o que eu vou colocar na estrutura mesmo do texto. Uma coisa que é interessante, que eu acho que tanto aqui no Globo A Mais quanto no... não sei se no online, a gente não pensa muito nessa questão da pirâmide invertida, pelo contrário, eu tento fazer com que o texto tenha pontos importantes do início ao fim, de modo a prender o meu leitor e oferecer coisas que vão prender ele até o final, porque a pirâmide invertida você coloca tudo no lead e já era. Então, penso na estrutura do texto, mas penso também, às vezes acaba não rolando isso, mas a gente tem um passa foto, um infográfico e um vídeo, eu acho que o vídeo é melhor colocar no início porque ele introduz a matéria, o infográfico ta falando de uns dados que estão nesse parágrafo então é bom ficar perto, porque a pessoa já lê esse parágrafo e mexe no info, tento fazer dessa forma.

A: Você utiliza algum critério para inserir link? 
B: Critério do que eu acho interessante. Eu não encho o texto de link, porque se não vai ficar parecendo a Wikipedia, mas se tem alguma coisa interessante eu gosto de colocar. Essa semana eu fiz uma matéria em que eu entrevistei um blogueiro, eu achei que seria interessante colocar o link do blog dele, então coloquei "Fulano de tal, autor do blog tal" e aí coloquei o link do blog dele, por exemplo.

A: O fato de você trabalhar em uma redação convergente trás alguma implicação no seu dia-a-dia, no seu trabalho?

B: Como assim?

A: Os jornais, as empresas do grupo estão trabalhando num espaço comum, isso trás algum impacto no seu fazer?

B: Eu acho ótimo. Às vezes as pessoas perguntam, "ah, mas você conhece os repórteres do Globo?", gente, eu não só conheço como eu trabalho com eles, está todo mundo aqui em volta. E eu acho isso bom, porque já aconteceu de eu estar fazendo uma matéria sobre economia, aí eu vou e tiro uma dúvida com os repórteres de economia, a gente já fez dobradinha de fazer matéria em conjunto, que é muito legal quando isso acontece. Então eu acho excelente.

A: Com a sua experiência profissional, você acha que houve alguma transformação com a inserção, de você trabalhar com um dispositivo novo, digital, móvel, você acha que há alguma diferença em termo de rotina, produção?

B: Acho que sim, como eu entrei aqui como estagiária e o Globo A Mais foi a minha primeira experiência já como repórter mesmo, eu acho que eu acabei desenvolvendo uma visão diferente do fazer jornalismo, eu vejo que os meus colegas que trabalham no impresso ou no online acabam tendo obrigações diferentes das minhas, e eu tenho essa oportunidade de pensar a pauta de uma forma um pouco mais global. 
Apêndice $\mathrm{H}$ - entrevista com Repórter 5 de O Globo A Mais

Entrevistador: Quais competências você considera necessárias para que o repórter atue no Globo A Mais?

Repórter 5: Olha, tem que ter uma inserção muito boa no que ta hoje inserido de software que é importante, ter uma noção de design é muito importante, ter uma noção de funcionalidade de diagramação também é interessante, não pode ficar um pouco a parte disse, ele tem que estar inserido nesse meio, tem que cogitar um pouco também dessas funcionalidades. Além disso, é importante ser uma pessoa que está antenada com as facilidades da ferramenta, você ter facilidade no pensar de uma arte, no pensa em um botão não específico pra interação com o leitor, a gente tem esse meio, a gente tem essa ferramenta, e você tem que aproveitar o máximo, uma tela animada atrai muito o leitor, uma animação de uma matéria é algo que também chama o leitor e faz com que o leitor fique fidelizado e isso é importante demais. Além das competências naturais de um repórter de um grande jornal como o Globo.

Entrevistador: Quais são as ferramentas que você utiliza normalmente pra produzir a informação?

R5: Então, eu gosto muito de apurar, e além das ferramentas, que é o Windesign normalmente, eu uso muito sites de rede social, sites de buscas, e o Twitter e o Facebook pra mim são chaves, porque eu gosto muito de achar casos peculiares, casos poucos badalados, fora da grande mídia, fora do grande centro, e o Facebook e o Twitter são uma chave pra essa função. Por exemplo, a gente está com uma série grande no Globo A Mais, desde o meio de agosto, que é a série "Gol da Alemanha”, e tem nessa série múltiplos casos que a gente foi achando, e a gente foi achando por via contato pela internet e via relações que a gente tem no ambiente, por exemplo, nos jornais esportivos eu tenho alguns colegas que a gente vai se comunicando, vai trocando algumas idéias, e eu vou falando pra eles aquilo que eu quero e eles vão me ajudando de alguma forma, sempre pescando aquilo que eu estou em busca.

Entrevistador: Eu posso sugerir pauta?

R5: Demais. Eu acho que é fundamental, além de ser pautável e trabalhar bem com o que lhe é pautado, você tem que saber sugerir pautas, saber o que está pulsando no momento. Nessa questão da nossa série a gente tem sempre que trabalhar com o que está pulsando, por exemplo, a nossa idéia pra próxima semana é apresentar um pouco do calendário do futebol brasileiro, o calendário do futebol brasileiro é um assunto que está em roda e é muito interessante a gente pegar aquilo que ta inserido no nosso cotidiano, tem questões que são 
importantes e que a gente tem que ficar de olho, nunca deixar a parte por se tratar de uma ferramenta pra tablet, eu tenho sempre que fazer com um olhar, buscar o olhar daquele público e falar “como é que ele vai querer ler um assunto tão importante como esse?".

Entrevistador: Ao sugerir uma pauta você tem uma preocupação com as características de tablet? Eu tenho que fazer uma pauta pro tablet, eu tenho essa preocupação?

R5: Em grande parte dos momentos, sim, dependendo da pauta, em outros casos, como a pauta é muito importante, a pauta pede pra ser feita a gente pensa nisso, deixa um pouco pra mais tarde, a gente faz a pauta e depois vê como vai funcionar, mas necessariamente é muito importante estar nesse meio e inserir esse pensamento. Você tem que começar a pauta pensando em como você vai animá-la, em como você vai apresentá-la, como você vai trazer de fotos, de artes, de inserção de interação com o leitor.

Entrevistador: Existe algum critério que vai validar essa pauta? Quais são os critérios que você usa pra sugerir? O que você enxerga numa informação que se transforma em pauta?

R5: Assim, eu gosto de trabalhar muito com alguma coisa que ainda não saiu, alguma coisa de novidade. Por exemplo, na semana antes do primeiro turno, em conversas com alguns conhecidos alguém me indicou que uma candidata de um partido do Rio de Janeiro veio pra eleição com o nome de "filha, volta pra casa", a filha dela tinha desaparecido, ela tinha histórias de desaparecimento, ela é inserida nesse meio, e ninguém deu isso, e eu sugeri a pauta, fizemos aqui no Globo A Mais, foi uma pauta de capa, pauta até bem interessante, ela conta a história dela, a filha dela tinha sumido, ela veio à frente de um grupo de pais que também tinham filhos desaparecidos, isso é um dos pontos que eu levo em consideração pra gente considerar como pauta aqui no Globo A Mais.

Entrevistador: Existe alguma orientação no sentido de produzir matéria multimidiáticas?

R5: Olha, eles pedem sempre pra gente pensar o máximo possível de interação com o leitor, se tiver vídeo vamos usar, se tiver fotos vamos usar, se tiver uma arte de toque, ou uma arte de mapas, vamos usar, sempre pensando previamente, sempre fazendo isso ao longo da semana pra nunca ficar sobrecarregado no momento final. É sempre necessário você ter um cronograma pra fazer esse funcionamento dar certo, ou por ser uma matéria que possibilite muito coisa a gente tem que ter esse cronograma bem definido pra no final não se confundir.

Entrevistador: Além do próprio texto, vocês produzem, você no caso, repórter, você produz algum outro formato?

R5: Nesse caso depende da situação, por exemplo, a gente tem o auxílio do pessoal do vídeo, caso a gente visualizar alguma matéria com vídeo a gente leva pro pessoal do vídeo, 
caso a matéria não peça isso a gente não mexe, ou você pode levar uma câmera sua ou um celular do jornal e você fazer esse vídeo, mas na qualidade deles fica melhor, na nossa é algo mais escondido, algo que não demanda isso, fotos a gente também tem essa facilidade, quando a gente quer visualizar uma foto pode levar, pedir e tudo mais. Mas basicamente a nossa função aqui é muito produção, ideias de pauta e finalização do produto mesmo.

Entrevistador: Qual critério que você utiliza pra pensar num formato em detrimento do outro? Tipo, "ah, eu acho que nesse formato o vídeo se adéqua melhor... ah, eu acho que aqui o áudio".

R5: Acho que depende muito da facilidade da pauta, por exemplo, uma pauta sobre YouTube, você vai poder usar um vídeo, uma pauta sobre uma menina que tem um canal no YouTube, a gente vai trazer essa facilidade pro Globo A Mais. Por exemplo uma pauta que teve sobre as músicas de tribos indígenas, fizemos com áudios. Isso vai de acordo com as pautas, por exemplo, nessa pauta das tribos indígenas nós só tínhamos o áudio, então não fizemos alguns botões interativos em que a pessoa ia clicando e ouvindo a música.

Entrevistador: Por ser um suporte móvel, por ser um dispositivo móvel, existe fontes que são mais adequadas pra usar na matéria ou não?

R5: Fonte você diz fontes de...

Entrevistador: Fontes de produção da informação.

R5: Fontes jornalísticas?

Entrevistador: Isso.

R5: Depende, depende do tema, não tem uma prioridade entre um personagem ou outro, nós vamos fazer o jornalismo, correr atrás daquele personagem que é necessário pra nossa matéria, se eu tiver que falar com os vinte presidentes dos clubes da série A do Brasileiro eu vou falar com gente, independente deles estarem inseridos ou não. Isso não cabe nesse momento.

Entrevistador: Você utiliza de alguma forma a memória do que já foi produzido?

R5: Utilizo, a gente utiliza muito, nesse caso da série "Gol da Alemanha", a gente utiliza muito pra vender um pouco a série, a gente tenta vender a idéia da série pra todos os nossos próximos alvos, por exemplo, já temos seis matérias, ela está com um sucesso bacana, ela tem uma divulgação na televisão, enfim, a gente usa o que for possível pra melhorar o nosso trabalho, pra melhorar o nosso texto, trazer uma pesquisa, o que saiu, ou o que não é novo, enfim, mas também pra divulgar.

Entrevistador: Existe algum planejamento da arquitetura da informação? Você quando pensa na sua pauta você pensa em como vai ser a navegação da matéria? 
R5: Penso, penso, com certeza, por exemplo, tem algumas matérias, as últimas matérias da gente elas tem sido um tanto quanto extensas, como elas são extensas, pra não ficar um grande bloco de textos, a gente divide as animações, faz duas animações, em cima faz uma foto galeria, embaixo faz uma animação interativa, e isso a gente vai colando, se a galeria fica melhor em cima a gente coloca ela em cima, pra fazer a arte embaixo explicando o que cada personagem da matéria é ou fez, trazer um perfil de cada, como ela está no final, os personagens já foram aparecendo gradativamente ao longo do texto, a gente trás esses personagens mais embaixo.

Entrevistador: Em que momento isso é pensado?

R5: Ah, muitas das vezes durante a elaboração do texto, após a produção de grande parte da matéria, fazer as entrevistas e aquilo que foi apurado, a gente vai pensar um pouco da interação. A última matéria que o Globo liberou agora foi sobre a nova formatação política da câmera dos deputados com a eleição, a gente fez uma foto galeria em cima, trazendo alguns dos personagens, e embaixo trouxe um perfil de todos eles após a presença deles na matéria.

Entrevistador: Qual critério vocês utilizam pra inserir link em um texto?

R5: Depende muito do caso, os links são muito inseridos nas dicas que nós fazemos no Globo A Mais, depende da dica a gente faz um link pra entrar no site do serviço ou num site de referência, por exemplo, é um Google ou um site que é novo no mercado, um site de pedagogia, por exemplo, aí tem uma dica falando do site a gente dá um link com o nome dele, acho válido nessas situações. Nas grandes matérias confesso que eu não utilizo, nas dicas são mais presentes.

Entrevistador: Há uma preocupação quando você elabora o seu conteúdo quando à interatividade?

R5: Sempre, sempre, quanto maior a interatividade melhor o conteúdo da matéria, não adianta ter um texto bom e uma interatividade pobre, a gente tenta facilitar ao máximo o entendimento da matéria pelos personagens, por aquilo que a gente quer apresentar, acho que quanto melhor a interatividade a matéria só tem a ganhar.

Entrevistador: Você utiliza algum padrão do modelo do texto? No sentido de uma pirâmide invertida ou não tem esse tipo de preocupação?

R5: Eu gosto muito de trazer o personagem, um dos personagens centrais do texto, logo de cara, abrir com ele, contar um pouco da história dele. A gente fez muito disso nas primeiras matérias dessa série que eu te falei, e dependendo do texto eu gosto muito de pegar esse personagem, contar um pouco da história dele e trazer "esse é o caso de fulano, que se assemelha a tantos outros casos", que é o cerne da matéria. 
Entrevistador: Há um tamanho consolidado de texto?

R5: Ah, no Globo A Mais isso é complicado, a gente teve textos bem grandes nas últimas matérias, que até no online ficaram grandes, ficaram um bloco bem grande de texto. A gente tenta passar algo que o leitor não se sinta cansado na hora de ler, quem sabe 10 parágrafos, não mais que isso.

Entrevistador: O fato da redação do Globo A Mais estar numa redação convergente impacta de alguma forma o processo de produção de vocês?

R5: Sim, com certeza, por mais que a gente esteja numa mídia auxiliar, numa mídia que não está inserida na internet ou no jornal a gente tem que ficar ligado, estar interado daquilo que está acontecendo, se a gente está com economia aqui do nosso lado a gente vai ouvir comentários, vai saber o que está acontecendo em economia, aqui na cidade também com os jornais de bairros. Eles nos influenciam mais, nós sabemos aquilo que está pipocando muito em função da movimentação deles, as movimentações de pautas, enfim, acho que após uma matéria no Globo A Mais eles podem se movimentar também, a gente faz eles se movimentarem, mas é muito raro a gente pegar algo que saiu neles e repercutir, a gente faz eles repercutirem a gente.

Entrevistador: Houve uma transformação no processo de produção da notícia, nesse contexto de uma redação convergente e produzindo para um dispositivo móvel, eu imagino que seja difícil pensar porque nós não vivemos em outras épocas.

R5: É, no nosso caso eu acho que essa convergência de mídia, funciona em casos exclusivos, em casos determinados, por exemplo, na morte do Eduardo Campo, nós tínhamos que dar uma coisa sobre o Eduardo Campos, no caso do Levi Fidelix, nós tínhamos que dar uma coisa sobre Levi Fidelix, e pra fugir daquilo que ta no ar e que vai no jornal amanhã a gente tem que estar convergindo com todo mundo, saber o que todo mundo está dando. Essa convergência é maior entre eles dois, entre o site e o jornal, no nosso caso a gente está muito mais envolvido naquilo que a gente considera diferente, mas nos casos extraordinários a gente tem que estar convergindo com eles. 
Apêndice I - entrevista com Repórter 6 de O Globo A Mais

Entrevistador: Qual é a função do repórter no Globo A Mais?

Repórter 6: Por se tratar de uma revista, tem que gostar de escrever bastante. Então, tem que ter esse texto, mais fluido. E, acho que, um poder de apuração maior, porque você não só vai colocar no texto, mas informações adicionais para o leitor. Assim, boas fontes, checar as fontes, é muito importante. Até porque não é um site que a gente pode modificar um erro. Aqui quando vai, é mais ou menos como papel. E aqui também, em geral, não funciona muito essa coisa de "erramos". Não tem esse espaço aqui. Então, a gente tem que checar muito a informação, é bem diferente aqui nesse sentido.

Entrevistador: Quais são as competências que você acha necessárias para assumir a sua função aqui no Globo A Mais?

R6: Telefone e internet. A gente vai pelo Google, eu procuro muito ir em Associações, Universidade. Por exemplo, uma matéria sobre política, eu vou procurar cientistas políticos das Universidade mais renomadas do Brasil. Eu procuro ir para instituições mesmo, para não ter erro da informação não ser confiável. Obviamente, a pergunta.

Entrevistador: Isso você acha que inviabiliza a publicação de um assunto?

R6: Aqui sim, acho que foram raras as vezes que ganhei uma pauta. A gente sugere muito e faz. Até por se tratar de uma revista a gente tem reunião de pauta semanal, cada um leva sua sugestão, acaba que o editor sugere uma coisa ou outra e ai quem gostar, pega. Mas a gente sugere muita matéria aqui, é meio inverso dos outros lugares que já trabalhei, onde a gente era demandado. Aqui a gente cria nossa própria demanda.

Entrevistador: Quais são as ferramentas que você utiliza no seu dia-a-dia, como repórter? Ferramenta bem ampla, software, há uma diferença?

R6: Existe. Ainda mais aqui, que a gente está dentro de um jornal. A gente concorre com nosso próprio veículo, que a gente gera. Então, a gente tem a preocupação de não estar competindo nem com jornal, nem site. A gente tem que sempre fazer conteúdo extra. A gente tem que ter essa preocupação de ser material extra, a mais, até por isso o nome da revista. E a gente trazer uma coisa diferente para o leitor.

Entrevistador: O repórter sugere pauta?

R6: Olha, em geral, são pautas... é difícil você chegar lá. Em geral, são pautas, que o dia a dia no jornal, não consegue pegar, e o site também não. Porque no site as pessoas não querem ler muita coisa, então o site acaba ficando com as matérias mais reduzidas.

Entrevistador: E você tem essa preocupação na hora em que você vai sugerir a pauta? 
E quais são os critérios que você utiliza para sugerir essa pauta?

R6: Então, aqui a gente faz matérias mais aprofundadas, a gente pode realmente apurar, ir a fundo, me fugiu aqui a palavra agora, mas assim, é longe do conteúdo superficial, aqui é ao contrario, são matérias mais analíticas. A gente procura ouvir muita fonte para realmente, de fato, ter uma visão ampla da coisa, não abordar por um lado só. Acho que aqui são matérias multifacetadas.

Entrevistador: Você já me falou mais ou menos, mas as mídias sociais exercem alguma influência na construção dessa pauta?

R6: Exercem, claro. A gente está sempre de olho no que está acontecendo nas mídias sociais até por sermos um veículo digital, a gente dialoga muito com isso.

Entrevistador: Existe alguma orientação quando você entra na produção dessas matérias multimidiáticas?

R6: Então, o que está acontecendo no mundo virtual, nas redes sociais, interessa muito a gente. A gente faz muita pauta sobre mídias sociais aqui, tendências. Não só tendências, porque em geral, o jornal faz a tendência. A faz a análise da tendência, o que isso significa, a parte sociológica, até antropológica da coisa. A gente faz essa análise mesmo.

Entrevistador: Com vários formatos, você é recente, você entrou há pouco tempo aqui, mas existe uma orientação no processo de produção delas? Você só faz texto, mas você também tem que escrever em novos formatos, criar narrativas.

R6: Começa pelo que normalmente chega na gente, ou que a gente vai atrás. Por exemplo, me interesso por questões ambientais, meio ambiente, então, eu faço parte de alguns mailings que recebem noticias de mundos e estudos, então, começa por ai. Mais ou menos do que chega a você e o que você procura e dai você tira "ah, isso rende uma pauta" e a partir dai você vai ver se aquilo de fato rende. Então, a primeira fase, é o seu olhar no que você recebe e procura. A segunda, é aonde você vai buscar essas informações, que é como eu estava te falando pegar instituições, de especialistas e também pesquisa do que que já saiu aquele assunto em outros lugares. A terceira são as entrevistas. E quarta é a produção da matéria, analisar todo material q você absorveu e escrever.

Entrevistador: Quando você produz o texto, tem alguma preocupação com o formato? Formato que eu digo, pirâmide invertida ou qualquer coisa do gênero?

R6: Sim. Aqui a gente fala enriquecimento. Tem essa orientação quando a gente chega aqui. A gente não tem...eu não tive, eu sou nova aqui, eu não tive um treinamento das possibilidades que a gente tem. Isso a gente vi pegando no dia a dia, quando a gente vai na reunião de pauta, tem pessoas que são mais antigas aqui, a Tais está aqui há bastante tempo. 
Então, a gente da uma sugestão e elas já vem, as pessoas já vem com ideias de enriquecimentos. Então é uma coisa que a gente acaba trabalhando em time mesmo.

Entrevistador: Qual é o critério que você utiliza para escolher um formato em detrimento do outro, por exemplo, eu vou usar vídeo em vez de usar áudio, eu quero utilizar a foto.

R6: Não. A gente até faz produção de vídeo, mas a gente não edita. Eu fui no Manguê ontem, grava um pouquinho aqui, o fotografo grava também na gol pró, e a gente...mas ai quem edita é o pessoal de vídeo aqui.

Entrevistador: Uma fonte deixaria de entrar numa matéria, uma limitação, por exemplo, essa fonte seria ideal eu utilizar um vídeo dela, eu teria que ter um áudio, ela deixaria de entrar no conteúdo da sua matéria por causa de uma ausência de um formato específico?

R6: Vídeos fazem mais sucesso. Áudio, a gente até já fez matérias, por exemplo, você está fazendo uma matéria sobre música, você vai botar um áudio ou outro Mas vídeo em geral, comunica mais que o áudio, ainda mais quando se trata de um veículo que é voltado para aparelhos que tem essa coisa da imagem muito forte, que e o smartphone, o tablet. Então, em geral, a imagem vale muita coisa aqui para a gente. Por isso que a gente até procura fazer, abrir com fotos bonitas, fotos grandes, que é uma forma de chamar atenção e também é uma maneira de fazer com que a pessoa absorva aquilo ali melhor, porque no áudio as vezes 
Apêndice $\mathrm{J}$ - Editor 1 de O Globo A Mais

Entrevistador: Como é que são sugeridos e quais são os critérios utilizados pra sugerir uma pauta?

Editor 1: Isso é uma coisa um pouco decepcionante, é velho jornalismo, a pauta de interesse das pessoas, com uma conexão com o noticiário ou que tenha alguma revelação, é muito difícil, a gente muito raramente faz um hardnews no sentido exclusivo Paulo Roberto Costa(1:34s - Conferir o nome). Porque por ser um produto ainda periférico, hoje está mais difícil pras fontes do que pros jornalistas entenderem a migração digital, as fontes ainda estão na valorização do papel, então é muito comum se o Paulo Roberto daria mais pra um papel e não pro digital, a gente nota muito isso. Mas nós conseguimos aqui, a gente busca pautas exclusivas e a gente tem como, principalmente pra quem faz, limitação de espaço, a pauta tem o espaço que ela merece ter, o texto tem o tamanho que ele merece ter, a qualidade de fotos é a qualidade de foto que vale a pena botar, não é que nem no papel em que você está limitado ao espaço físico. Aí a gente vai atrás de assuntos que sejam de interesse das pessoas, por exemplo, a gente está fazendo agora, pra edição de sexta-feira agora, uma matéria sobre a igreja Universal do Reino de Deus por causa da candidatura do Marcelo Crivella e desse assunto ter entrado no debate eleitoral. Então esse assunto tem uma conexão direta com o noticiário do momento, mas a gente busca também pautas exclusivas que não tem conexão, talvez o grande exemplo seja uma negociação que levou meses que a Maiá Menezes, que hoje é de economia, ela era daqui do Globo A Mais, e ela conseguiu depois de meses de negociação entrevistar pela primeira vez, nunca aconteceu, o principal empresário de ônibus do Rio de Janeiro, um dos maiores do Brasil, que é o Jacob Barata, eles estavam super sufocados pelas manifestações, pela questão dos políticos que se aproveitaram um pouco disso, coloram os caras mais no pau ainda, e aí a Maiá sacou isso e foi atrás de negociar uma entrevista com ele, ficou meses, até que saiu a entrevista, aí saiu aqui no Globo A Mais. Um outro exemplo, um outro momento diferente do dia-a-dia da revista, foi quando o André Miranda que hoje é repórter do (4:00 - Não entendi), que era daqui também, ele conseguiu com exclusividade a carta da Ana de Holanda, a carta que ela escreveu pra Dilma reclamando da falta de recurso pra cultura e que acabou levando à demissão dela, essa carta foi revelada pela gente, então o Willian Bonner no Jornal Nacional quando conta a história da carta ele cita o Globo A Mais, revista digital do Globo. Isso são momentos de exceção, no dia-a-dia a gente fica atrás de pautas que tenham um link com o noticiário daquele período e que permitam um aprofundamento dos assuntos. Desde o início, somente uma matéria, que foi no 
segundo dia do Globo A Mais, saiu estática, era só uma foto e um texto, todas as matérias têm enriquecimento.

Entrevistador: As características do tablet é levada em conta quando é pensada essa pauta?

E1: Completamente, todos os repórteres, toda a equipe, está condicionada a pensar a pauta pro tablet, inclusive quando a sugestão chega sem a idéia do enriquecimento, o autor já fala "pô, eu to com dificuldade de pensar no enriquecimento da matéria", daí pensamos juntos, não tem a possibilidade de sair sem alguma técnica. Então, assim, por exemplo, a gente fez uma matéria na semana passada, a gente tem uma série do futebol brasileiro chamada "Gol da Alemanha", que tem como gancho a goleada da Copa do Mundo, e aí a gente tem algumas pautas, como a que a gente fez semana passa, falando da bancada da bola no congresso, é uma pauta dificílima de você ilustrar, daí a gente criou lá um infográfico que falava sobre os parlamentares que iam fazer parte desse grupo, e aí conseguimos ilustrar também com enriquecimento. A gente sempre pensa, porque a gente entende que quem assina o Globo A Mais ele quer ver a coisa que agrega essa ferramenta, não quer um jornal na tela.

Entrevistador: Eu vi você falando muito sobre enriquecimento, colocar uma foto seria enriquecer? O que é enriquecer?

E1: Enriquecer é você adequar a matéria à ferramenta, por exemplo, nessa matéria da Universal a gente vai fazer um mapa-múndi com os países em que a Universal é no mundo, você vai tocar e vai aparecer os dados sobre a igreja Universal naquele país. Todas as nossas matérias tem algum tipo de enriquecimento, qualquer interatividade que tiver é um enriquecimento.

Entrevistador: Há alguma avaliação de réplicas (7:15s) tanto do portal quando de qualquer outro suporte do grupo para você propor algum assunto...

E1: Desculpa, não entendi.

Entrevistador: Avaliação de (Mesmo termo grifado acima), números indicam que vocês precisam abordar tal tema...

E1: Não, editorialmente falando não, uma visão nossa. $\mathrm{O}$ que a gente percebe e aí a gente volta ao velho jornalismo, diferentemente da política, o bom jornalismo é o velho, a política boa é a nova, o bom jornalismo pra mim é o velho, a gente nota que notícia, um furo, matéria de impacto, a audiência sobe, os números mostram isso, tem mais download e tal. Durante muito tempo a edição mais baixada, a nossa campeã de audiência foi a edição da morte do Hugo Chavez, porque o Hugo Chavez morreu num momento super conveniente pra gente, a gente tinha uma matéria pronta, uma matéria que não era um mero obituário, a 
matéria falava da política da América do Sul pós Hugo Chavez, a matéria estava pronta, fechada, e ele morreu acho que 5 h30 da tarde, então essa edição, eu não sei se ela continua sendo a mais baixada, acho que não, acho que já foi ultrapassada, mas foi durante muito tempo. E a gente nota também que faz muito sucesso coisas ligadas ao perfil do usuário do iPad, então, por exemplo, a gente teve um sucesso de audiência esse fim de semana agora, a gente fez uma edição especial, porque o Globo A Mais é só de segunda à sexta, a gente fez uma edição especial de domingo, que até a Josi que fechou essa edição com o Ted, e a edição foi muito baixada, teve muita audiência, porque eu acho que, aí na minha opinião, a gente não tem pesquisa qualitativa que comprove isso, mas na minha opinião, isso tem a ver com o fato do leitor ser ligado nas coisas que o Ted fala, então por isso eu acho que veio esse sucesso.

Entrevistador: As mídias sociais tem influenciado de alguma forma na produção da edição de vocês, na sugestão de pautas?

E1: Sim. A gente vai muito dos assuntos que a gente vê, por exemplo, a gente deu uma capa aqui no dia seguinte, inclusive eu acho que o Levi Fedelix (09:44 - 09:48 - Não entendi), a gente, foi até uma decisão minha, na segunda-feira, isso foi no domingo, na segunda-feira eu cheguei aqui e a gente botou três repórteres pra fazer uma matéria, pra botar de pé, estava meio em cima da hora, pra botar de pé uma matéria na qual a gente falasse na questão do Levi Fidelix. Porque eu tive essa idéia, porque eu vi que estava nas redes sociais, aquilo ali já me chamou a atenção de que tinha um fenômeno a ser discutido, a ser abordado, a gente fez uma capa super legal que é um carão dele, a cara da homofobia, também teve uma audiência bem compensadora. A gente tenta misturar agilidade e profundidade, não ser completamente fria, a não ser quando é dia que não tem notícia, aí a gente usa matérias mais frias, sei lá, a gente estava produzindo uma matéria sobre o manguezais da Baía de Guanabara, um estúdio sobre a situação desse manguezais, essa pauta é uma pauta exclusiva nossa, que a gente vai usar num dia em que não tenha notícia.

Entrevistador: Essas notícias precisam de uma durabilidade maior?

E1: Não, porque a gente não demora muito, ela vai ser produzida amanhã, a repórter vai pra rua e vai fazer essa matéria, a gente deve colocar ela segunda ou terça-feira no máximo. A gente também busca, por ser um produto prêmio, a grande estratégia do Globo é que o Globo A Mais seja uma das principais, o Globo, a empresa, e aí eu to falando dos donos da empresa, os donos da empresa entenderam que a única salvação, vou repetir a frase que o diretor de redação usou, a gente entende que fazer jornal não vai mais nos sustentar num futuro próximo. Se alguém inventar um jeito do jornal voltar a nos sustentar a gente volta a fazer jornal como a gente sabe fazer, mas como ninguém inventou ainda a gente precisa de 
uma fonte de renda, a fonte de renda atual que a empresa acredita é a assinatura digital, inclusive como uma substituta da publicidade. E aí o cool, o principal chamariz pra novos estudantes é o Globo A Mais, daí até hoje ser um produto que é como se ele não fizesse parte do Globo, totalmente exclusivo, as matérias dele não saem no Globo e as matérias do Globo não saem nele.

Entrevistador: Existe alguma decisão, o que leva um repórter a campo, a apurar?

E1: A gente tem uma brincadeira aqui que os jornais de um tempo pra cá, eu vou te falando e você vai vendo como é a nossa forma de trabalhar, os jornais de um tempo pra cá começaram a chamar de perfil uma coisa que é entrevista, por exemplo, vou fazer um perfil teu, o repórter vai lá te entrevista e escreve e coloca que isso é seu perfil, isso não é um perfil, perfil é óbvio que aquilo é fake (13:07 - 13:12- Não entendo), então assim, é aquilo, você ouve um monte de gente, tem um perfil da Dilma na Piauí recente, por exemplo, tem 26 pessoas na Dilma, isso é um perfil, e aqui a gente diz que é perfil com sofrimento (13:15 13:29s - Conferir), que é uma moleza, você vai lá entrevista e publica, não, a gente aqui reúne um monte de gente, conta histórias do bem e do mal, então, assim, por isso que quem trabalha com apuração é muito exaustivo, é muito grande, a matéria cansa de voltar, você tem que fazer a matéria de novo, porque a gente entende que se você abrir mão do conteúdo em nome da forma, para que a gente use só o enriquecimento que o tablet permite, interatividade, você está abrindo mão do seu trabalho, como ofício. Então, quem garante que o leitor vai ler uma matéria desse tamanho? Ninguém, nem eu, mas o meu trabalho é incentivar, obrigar o leitor a ler essa matéria desse tamanho, tornando essa matéria mais amável pra ele, então o texto tem que ser bacana, não pode ter erro, tem que ser bem apurado, de novo como o velho jornalismo.

Entrevistador: Quais ferramentas são utilizadas nesse processo de produção?

E1: Em que sentido?

Entrevistador: Ferramentas no sentido bem amplo, softwares, repórter tira foto?

E1: Sim, hoje em dia, é até pra mim uma coisa que eu trato como uma novidade, digamos assim, repórter da minha idade, da geração a qual eu faço parte, eu comecei a trabalhar com a máquina de escrever, sou bem pré-computador, mas os repórteres de hoje em dia já vão com celular em punho pra fazer foto e vídeo. E a gente tem também uma estrutura, já que a imagem é tão valorizada, a gente tem uma estrutura de ir com fotógrafos, de fazer vídeo, tem assuntos que a gente pensa neles como vídeo-reportagens. Sexta-feira passada a capa foi uma matéria falando dos perigos de se fazer rapel, que aqui no Rio tem muito essa atividade nas encostas e tudo mais, e a gente fez uma vídeo-reportagem com o principal 
instrutor carioca de rapel explicando as precauções que as pessoas tem que ter, aí é uma coisa parecida com a televisão, a gente vai pra rua com cinegrafista, tem uma edição, mas assim, o vídeo formado, o vídeo artesanal também nos interessa e os repórteres fazem direto isso também.

Entrevistador: Por ser um aparelho móvel, isso impacta de alguma forma no processo de produção? Vocês pensam “eu estou produzindo conteúdo pra um dispositivo móvel”, aí eu não estou falando de potencialidade, estou falando de deslocamento, um produto que é consumido em deslocamento.

E1: Não, na verdade não, nunca pensamos nisso, que a gente tem um entendimento também que aqui no Rio de Janeiro, nosso público está concentrado no Rio de Janeiro, muito pouca gente, tipo, tira um tablet num ônibus, ele acaba sendo consumido em casa, e a gente tem uma versão também pra smartphone, o Globo A Mais tem três ambientes, tablet, smartphone e o site, por exemplo, a versão do smartphone se você olhar ela é bem mais precária, mais simples do que a versão pra tablet, e a matéria está toda lá, na íntegra, a gente não abre mão, a gente não negocia o conteúdo, é uma questão de sobrevivência nossa mesmo, pra levar o leitor a se interessar por aquele conteúdo.

Entrevistador: Há algum aproveitamento de outros arquivos, de outras edições?

E1: Sim, não só de outras edições como de outros arquivos mesmo, a gente tem uma sessão, "Finda", como se fosse uma contra-capa, que ela foi inspirada até, não sei se a Carta Capital ainda tem isso, mas geralmente na Carta Capital a última página era um retrato de alguém, uma história, então a gente faz isso também com o Globo A Mais, então por exemplo, hoje a nossa capa é uma matéria sobre as novas bandas de rock, sem nenhuma conexão com o noticiário, o noticiário está meio, está todo mundo esperando a pesquisa eleitoral, que vai ser depois do nosso fechamento, e estamos fazendo uma matéria grande pra sexta-feira, então a gente pegou uma matéria mais simples sobre essas novas bandas de rock, então a imagem é retirada do acervo do Globo, vai ser os Mutantes, porque são um grupo de rock mais antigo, então a utilização do acervo é diária nessa sessão e nas matérias também.

Entrevistador: Isso é o repórter que faz?

E1: Também, a gente cria meio em conjunto, os repórteres tem todos os domínios sobre as edições, eles entregam o texto final pra nossa revisão.

Entrevistador: Existe um planejamento prévio da arquitetura da informação?

E1: Em que sentido?

Entrevistador: Em sentido de navegação, quando tem essa pauta o repórter pensa em como é que vai ser navegado ou quem pensa e em que momento isso é pensado? 
E1: Os designers, vai ser bom você conversar com eles também, isso é muito importante pra sua pesquisa, eles precisam de bolar a matéria no sentido da edição mesmo, não só da disposição gráfica, como também do que precisa ser apurado, precisa ser conseguido pra edição ficar bem enriquecida. Um produto como esse ele redefine o papel do design numa redação, como é que era no jornal, que é até hoje, ta vendo aquele menino de camisa listrada, ele é design do jornal, ele fica sentado ali, os editores vão chegando e dizem pra ele "eu tenho uma matéria com uma foto, tenho um bom contexto" e não tem nenhum tipo de conexão com a matéria em si, o que está escrito ali pra ele pouco importa, aqui não, aqui para que o design possa criar o trabalho gráfico dessa matéria ele precisa saber que matéria que é, o que vai ter nela, o que é mais ou menos interessante, inclusive eles têm poder de veto, então a gente pensa numa matéria e eles acham que graficamente não vai dar, tem sempre essa conexão.

Entrevistador: Certamente eles precisam de compreender um pouco essa $(21: 03 \mathrm{~s})$

A: Sim, e eles compreendem, e são muitos, são três designers, proporcionalmente pro tamanho do grupo é muito, mas precisa sim, porque é um grupo muito trabalhoso de fazer.

Entrevistador: Existe algum critério pra inserção de inter-texto?

E1: O critério é o repórter sugerir, pensar numa matéria com esse inter-texto, ou o design encontrar isso como uma solução para alguma questão gráfica da matéria.

Entrevistador: Alguma preocupação com a interatividade com o conteúdo?

E1: Sim, o tempo todo, o tempo todo, a gente preocupa o tempo todo, a gente entende que esse é um produto que não pode abrir mão, não pode fazer concessão a se burocratizar, tem que ser inovador, tem que ser bonito, tem que ser interessante todo dia, e aí é a barra pesa porque se você faz uma coisa ficar interessante hoje, amanhã a pessoa não vai esperar que seja igual.

Entrevistador: Existe alguma perspectiva de personalização do conteúdo? Usar, por exemplo, eu sou usuário e eu gostaria de mudar a capa.

E1: Não.

Entrevistador: Ou eu estou na região sul e ter um item específico.

E1: Não, a gente não pensou nisso, eu acho que ainda não é o caso e tem limitações tecnológicas. Por ser um produto pioneiro, a gente meio que cresceu junto com os esforços de execução mesmo, a gente tinha no início, quando o Globo desenvolveu o Globo A Mais foi uma empresa de São Paulo, chamada Digital, que criou o sistema pra fazer isso, a gente teve mil problemas que eu hoje atribuo ao fato de ser pioneiro, esse ano a gente ficou dois dias 
sem sair porque a Adobe teve um problema mundial, hoje o nosso design aqui é Adobe, ele teve um problema e nada saia, ficou dois dias sem sair, é uma coisa que não ia acontecer num jornal de papel, mas aconteceu aqui com a gente e ficamos dois dias sem sair. A gente ficou o tempo todo tentando atualizar, eles não falaram o que que era, então a gente ficou de meia em meia hora tentando.

Entrevistador: Você tem utilizado de alguma forma a memória do que é produzido pra fazer novas informações?

E1: Só quando, por exemplo, o repórter lembra pra fazer a evolução daquele fato.

Entrevistador: Há um tamanho aconselhado pra tamanho de texto?

E1: O tamanho que for melhor pra mim.

Entrevistador: E existe uma orientação de número de textos por dia?

E1: A gente uma matéria por dia, essa orientação vem mais da limitação quanto ao número de pessoas, a gente tem muito menos gente do que deveria, e aqui a gente acaba também submetido à isso.

Entrevistador: Como é que é feita a escolha das matérias que viram infográfico?

E1: É o que a matéria merece, o ideal é que todas as matérias tivessem, mas tem matéria que não merece.

Entrevistador: Como é que eu escolho um arquivo midiático, como que eu escolho um áudio em detrimento de um vídeo?

E1: As vezes é o que a gente consegue, às vezes é só o áudio, não tem o vídeo, e às vezes tem a ver com o design, ah, e tem uma questão do vídeo também, tem com o áudio também, mas menos, aí é uma coisa até parecida com o papel, a gente tem um tamanho, um peso, se você põe muito vídeos, se fica muito pesado o leitor desiste de baixar, você tem que ter um bom controle disso também. Então a gente sempre acha que de três vídeos pra cima a gente já acha que não porque vai ficar muito pesado, fica em torno de 100 mega. (Pergunta pra Raquel qual o tamanho que eles consideram que fica pesado, ela responde que é 120 mega e fala alguma coisa de sexta-feira). É, também tem isso, na sexta-feira a gente faz uma edição maior, a gente tem uma matéria por dia todo dia, na sexta-feira a gente faz três matérias que é uma espécie de edição de fim de semana.

Entrevistador: Existe algum manual que orienta a edição desse conteúdo?

E1: Não, a gente faz passando um pro outro.

Entrevistador: Mas você trabalha sob as orientações do manual do Globo?

E1: É, a gente usa basicamente o que o jornal já determinava, tem mais ou menos o mesmo critério. 
Entrevistador: Existe algum padrão, algum modelo pra reportagem?

E1: Não, é o contrário, a gente se inspira nos melhores modelos que o jornalismo tem disponível, então assim aquilo que eu te falei, todo mundo aqui busca uma coisa mais interessante, mais bem elaborada possível, o texto também busca essa excelência.

E1: Como assim? Não entendi.

Entrevistador: Por que a matéria do rock vai pra capa? Quais são os critérios pra dizer "olha, essa vai pro destaque, essa não"?

A: Vai muito da nossa avaliação mesmo, mesma coisa de sempre, se é uma informação exclusiva, se é bem apurada, por ser um produto Premium a gente busca matérias de mais qualidade, o jornal ele se conforma, tem uma hora que chega e vai isso mesmo porque é o que tem, a gente procura uma coisa mais elaborada e a gente não aceita também coisas que saíram no jornal no dia anterior.

Entrevistador: Há alguma mudança na proposta inicial do Globo A Mais?

E1: Relevante não.

Entrevistador: A proposta do a mais continua?

E1: Claro, esse conceito continua intocável, um produto pra você ver além do que vê no Globo, as matérias dele acabam sendo melhores que do jornal do Globo.

Entrevistador: E essa concepção da análise do dia, analisar os acontecimentos, da coisa que é feita durante o dia, isso se mantém?

E1: A gente tem uma área de noticiário do dia, que é o Giro (Para pra conversar com alguém)... Sobre o que a gente estava falando?

Entrevistador: A gente estava falando sobre o a mais.

E1: A idéia é, a gente tem até um processo de doutrinação mesmo, não é pra fazer matéria de coisa careta, é pra fazer sobre coisas diferentes, coisas que criam uma concepção muito minha de jornalismo, e agora eu arrumei uma parceira muito, não que ela não seja, mas eu acho (30:14s - Não entendi), eu e a Jose a gente pensa muito parecido mesmo, por exemplo, essa outra jornalista, é uma jornalista mega importante do jornal, repórter investigativa super competente, mega premiada e tal, mas ela tem um jeito mais formal de ver o jornalismo, eu e a Jose também, a gente tem um jeito mais ousado, ousado não é a palavra, a gente quer...

Entrevistador: Possível inovar, inovador

E1: É, a gente quer inovar, quer tentar atrair o leitor com inusitado, é ousadia mesmo, é meio romântico, mas é um exemplo. A Thais, que é essa menina que acabou de mandar a mensagem que ta na rua fazendo matéria, ela viajou de férias pro Peru e o Peruo hoje é um 
país de turismo gastronômico super badalado, tem os chefes mais importantes do continente e tudo mais, aí ela contou essa coisa das férias dela e a gente resolveu que deveria virar uma matéria, primeiro que a matéria não foi só sobre as férias dela, não foi um relato de férias, ela foi fazer uma matéria da importância econômica do turismo gastronômico na economia do Peru e tal, e aí na hora de fazer a capa a gente optou pelo lado bem humorado, fazer uma piada, também chamar a atenção e até de chocar. Porque a pessoa não ler trás muitos problemas pra mim, um dos muitos fatores da decadência dos jornais é que os jornais provocam hoje indiferença nos leitores, no máximo você fica contrariado porque o jornal não agrada a sua opinião, seja política, seja esportiva, então ele não tem uma coisa de ir pro inusitado. Então a gente busca isso, e a gente busca isso nas pautas, tenta ser plural, é claro que pra isso a gente a vantagem de ser um grupo pequeno, tem limites mais largos, aqui a gente tem essa liberdade.

Entrevistador: Essa (23:22s) do digital em primeiro impacta de alguma forma na produção do Globo A Mais?

E1: Não, porque houve um anúncio...

Entrevistador: Em março.

E1: Fevereiro. Impactua assim, antes, até fevereiro como é que acontecia, a gente publicava as matérias do jornal antes, na origem, quando o Globo A Mais foi concebido, ele tinha a primazia de pelo menos uma matéria, uma editoria por semana, então assim, a editoria Rio produzia uma matéria então saia primeiro no Globo A Mais e no dia seguinte na editoria dele, aí você tinha uma conexão direta entre o jornal e o Globo A Mais, quando teve essa mudança pro digital, priorizou essa busca pelo digital, é o que eu te falei o Globo A Mais tem que ser exclusivo, ele tem que ser conversa e as pessoas tem que ser incentivadas, ser mobilizadas pra assinar pra poder ler, é pra ele ficar trancado e ninguém ter acesso a não ser pela assinatura, daí esse impacto nesse momento foi, tanto que a gente tem uma equipe, em tese, se você pegar de parâmetro o jornal de papel, nossa equipe é maior do que deveria ser, mas na verdade ela é menor do que deveria ser na verdade, porque a gente tem um volume de produção enorme, as matérias são produzidas no mesmo dia, a Renata nesse momento está apurando a matéria da igreja Universal e ela parou pra fazer as imagens do dia porque a gente não tem como deixar.

Entrevistador: Os editores do Globo A Mais eles tem outras funções?

E1: Só em plantão de fim de semana, que aí tem a ver com o tema do plantão, mas é só no fím de semana, eu tenho uma coluna minha, chamada Coluna Carioca, mas aí é porque me chamaram pra fazer, é uma coisa pessoal, me chamaram pra fazer, mas não impacta no 
meu trabalho aqui.

Entrevistador: O fato do Globo ter uma redação convergente trás alguma implicação no processo de produção? No contexto da redação está todo mundo integrado, isso impacta de alguma forma em produzir uma edição exclusiva?

A: Não, na verdade não, seria melhor se a gente tivesse a colaboração de mais gente de outras editorias, nossas matérias seriam ainda mais ricas, mas a redação é muito menor do que deveria ser, deveria ter muito mais gente que produz o que o Globo quer fazer. Por exemplo, olha aqui, vou citar de novo essa matéria, o programa dos pastores passam muito de madrugada, o pessoal vai ter que se virar aí, não dormir, pra fazer a matéria.

Entrevistador: Qual era o ideal?

E1: Um repórter ficaria só vendo de madrugada e os outros fariam as matérias do dia, não tem como, isso me constrange um pouco como gestor, mas não tem como.

Entrevistador: Qual o papel dos newsgate?

E1: Com a gente nenhum, graças a Deus.

Entrevistador: Pra mim o newsgate era a base de dados que geria, ele não faz gestão não.

E1: Ele é a plataforma, é o programa de publicação do Globo, onde o Globo é editado.

Entrevistador: Tá. E vocês utilizam de alguma forma pra que então?

E1: Pra pauta. A gente olha ele buscando pauta, mas é difícil da gente pegar porque as outras editorias pegam, é muito raro.

Entrevistador: Você já está aqui há um bom tempo, e acho que já conviveu com todas as transformações, como jornalista, o processo de convergência, essa integração transformou o processo do fazer jornalismo?

E1: Sim, e aí trouxe qualidades e trouxe defeitos. As qualidades, são profissionais muito mais bem preparados em relação à tecnologia, em uso de ferramentas, as mais variadas, hoje você tem que ser um técnico em informática também de certa forma, você tem que saber usar um aplicativo, tem que usar as redes sociais como atualizadores de notícia, mais do que um lugar de convivência e conflito, o Twitter é seleção de dicas de publicações o tempo inteiro. E aí essa qualidade provoca um defeito, que é o seguinte, a valorização desse tipo de informação, desse tipo de dado, que leva à uma desvalorização das qualidades do velho jornalismo, que continuam valendo, que é o bom português, porque a gente encontra muito assim o profissional que chega na redação que sabe mexer em tudo, mas não sabe botar crase, a gente tem essa dificuldade na chegada dos profissionais. Então assim, essas mudanças, o jornalista ele mudou como profissional mesmo, e aí tem muito esse defeito na entrada deles 
aqui.

Entrevistador: E como conciliar a produção de um conteúdo exclusivo nesse contexto?

E1: A gente tem um problema de muitas vezes ter coincidência de pautas, aí a gente negocia, tenta ser o mais original numa pauta exclusiva, numa idéia exclusiva, na abordagem exclusiva.

Entrevistador: Vocês participam dessa primeira reunião da manhã?

E1: Não, não participa de reunião nenhuma, porque como o nosso produto está fora da produção do jornal seria desnecessária essa participação.

Entrevistador: Qual é a função do editor do Globo A Mais?

E1: Revisar as matérias, checar os processos de produção, organizar a equipe e editar mesmo, fechar o produto, ler as matérias, saber o que o jornal quer de cada matéria e das sessões do produto.

Entrevistador: Existe alguma orientação para os colunistas?

E1: Não.

Entrevistador: Como é que os repórteres são selecionados?

E1: Desde o início a gente foi um formador poderoso de repórteres, como a gente estava começando do zero a gente pegou repórter jovem, e isso foi bom pra gente, a gente formou muita gente aqui, desde o início da carreira deles, o Mateus é um exemplo, a Bárbara, que você não conheceu, ela está na rua hoje, a Thais também está na rua, praticamente começaram aqui. E eu que sou mais experiente, mas que tem também a cabeça de vir pra cá e se integrar a isso, e junto, que não é desimportante, o contrário, a gente tem uma preocupação de sempre ter um bom ambiente, de ter parceria, dobra hoje e folga amanhã, a gente tenta isso pra fazer com que as pessoas não façam obrigadas uma matéria, é uma coisa pessoal mesmo, de cuidar das pessoas que trabalham pra elas estarem felizes, motivadas, na medida do possível, né, porque redação é um ambiente onde o salário é raríssimo, quem mais trabalha deveria estar bem, a valorização da evolução do tablet é super pouca, ou seja, a gente quer pelo menos tentar compensar isso no nosso ambiente.

Entrevistador: Existe uma competência básica, quais são as competências básicas pra esse trabalho?

E1: Essas que eu falei das habilidades tecnológicas, de saber o português, e de trabalhar muito.

Entrevistador: Eles passam por um treinamento?

E1: Aqui com a gente. A gente tem as reuniões de quarta como eu te falei com questões de texto e tudo mais, a gente fala do português, bota pilha, é sempre bom botar 
pilhar, "oh, tem que melhorar, não ta dando". 
Apêndice K - Editor 2 de O Globo A Mais

Entrevistador: Como é que são sugeridas e quais são os critérios utilizados pra escolher uma pauta?

Editor 2: Isso é até uma das coisas que eu queria, pelo que você me explicou sobre o projeto, porque uma coisa é o jornal, o impresso ou o site, produzirem um material que eles existem... esses jornais, o New York Times tem uma edição pro tablet, por exemplo, o Globo tem uma edição pro tablet, mas o flip (1:32s) do Globo ele nada mais é do que o Globo transposto pro tablet, você tem um efeito para o tablet, existem muitos produtos assim, simplesmente eles tem várias plataformas, você pode botar na web, pode botar no smartphone, tablet e impresso, isso é uma coisa, o Globo também faz isso. O Globo A Mais só existe no tablet e smartphone, ele pensa, o modo grande dele é completamente diferente, porque os outros eles nada mais são do que adaptações, você pode ser uma coisa ou outra, mas eles não são pensados assim desde o início, eles sempre nascem do impresso para a web. Então a gente realmente já pensa numa pauta, a pauta só existe se ela for multimídia, se não ela não é uma pauta nossa, ela é uma pauta, incrível pro jornal, mas não é uma pauta pra colocar no Globo A Mais.

Entrevistador: Ou seja, ela precisa ter...

E2: Ela precisa ter uma linguagem multimídia. E mesmo quando ela não tem e a gente acha que é uma pauta muito boa, a gente tenta pensar numa maneira. Se a pessoa não tiver uma experiência multimídia, no tablet, é uma perda muito grande, perde a função, né.

Entrevistador: Existe algum modelo estruturado, ela é apresentada em algum modelo ou isso não importa? Essa pauta.

E2: A gente tem uma reunião semanal, em geral toda terça-feira pela manhã, a gente faz essa reunião às $11 \mathrm{~h}$ da manhã e discute as pautas para até a próxima terça-feira, às vezes tem algumas pautas que vão até adiante disso, até em função da complexidade de você produzir um material multimídia. É muito mais complexo do que as pessoas imaginam, porque você trabalha com várias ferramentas, trabalhas com a instabilidade da web, tema, é muito mais complexo ter que produzir um material especificamente para isso, tem que ver se você tem áudio ou vídeo suficiente, as pessoas acham que se você tem áudio e vídeo vira multimídia, não é isso. A gente gosta muito mais de explorar essas ferramentas que são características dos tablets e dos smartphones, efeitos de fotos, efeitos de som, notícias interativas, efeitos de LED, coisas que as pessoas possam entrar na matéria, interagir com a matéria. 
Entrevistador: Certo. Há uma avaliação... (4:12s) tanto do portal quanto...

E2: Sim, o jornal pesquisa essas $(4: 19 \mathrm{~s})$ semanalmente.

Entrevistador: Mas a dúvida é, essas métricas influenciam a produção de vocês?

E2: Não muito, porque a gente é diária, a gente é de segunda à sexta-feira, sendo que a edição de sexta-feira é a edição de fim de semana, claro que a gente sabe que a edição de sexta-feira, até pela natureza dela, que ela é muito baixada no fim de semana, ela é maior, ela tem mais matérias, porque a gente sabe que é um dia mais forte mesmo, porque é uma edição que será baixada ao longo do fim de semana.

Entrevistador: Ou seja, esse acompanhamento vai influenciar a produção dessa estrutura.

E2: Nesse sentido sim, é uma coisa que a gente já esperava na verdade, a gente só comprovou.

Entrevistador: Mas as métricas do Globo A Mais influenciam na forma, você já percebeu se tem algo...

E2: Não, até porque a gente até gostaria que tivesse um padrão pra gente saber "oh, o nosso público gosta disso", mas matérias de assuntos variados tem picos de downloads, matérias de educação tem pico de download, matéria de política tem pico de download, matéria de saúde tem pico de download, interessa é o quão boa é aquela pauta, mas não necessariamente aquela área que ela está tratando.

Entrevistador: Você percebe que as mídias sociais influenciam na sua forma de produção?

E2: Influenciam pesadamente, não produção, mas a repercussão. A gente tem muita pauta que a gente tira de mídia social, a gente é usuário de mídia social, está o tempo inteiro conectado, o tempo inteiro. Eu leio, inclusive, muitos jornais e revistas pelo Facebook, fico o tempo inteiro ligada nele, a forma mais fácil. E assim como acontece com outros jornais, acontece com a gente também, então a gente vê às vezes assuntos que estão emergindo, tópicos que estão emergindo e transforma isso em pauta, tem muito isso, e também a gente sabe que é muito importante a divulgação em mídias sociais, a gente também aposta muito nisso, isso não vale só pra gente não, isso vale pra todas as plataformas.

Entrevistador: Os repórteres vão a campo, né?

E2: Vão, claro, hoje mesmo eu estou fazendo uma matéria grande de política e tem três repórteres fazendo, os três estão indo pra rua, já foram outras vezes, a gente vai bastante a campo, até porque é diário, mas não noticioso, factual, a gente consegue ir bastante pra rua, é fundamental. 
Entrevistador: Quais ferramentas são utilizadas nesse processo de produção?

E2: Olha, o Globo A Mais é feito no Adobe, no design, a gente usa as ferramentas que são disponíveis pro design, mas são muitas na verdade. E é publicado na Globo, então a gente só pode usar ferramentas que sejam compatíveis com os dois.

Entrevistador: Os repórteres tem uma base de dados para a produção do conteúdo?

E2: Não, a gente constrói as fontes, o jornal tem algumas, o jornal está até construindo isso, ainda está uma coisa meio preliminar ainda.

Entrevistador: Você mais ou menos já me respondeu, mas você construir para um aparelho móvel isso de alguma forma impacta na construção da informação? E aí eu falo da mobilidade, poxa, tenho um dispositivo que eu transporto, isso vai influenciar em alguma coisa na hora de vocês dispensarem a informação?

E2: Sim, mas é assim, é mais pela capacidade do dispositivo, a gente já sabe que ele é móvel, mas é móvel, mas também não é, porque em geral para você ler a revista você precisa parar, a não ser que tenha uma coordenação motora incrível, você vai ter que parar, geralmente vai ler num lugar em que você esteja sentado ou em pé num cantinho, lendo e tal. Então o que a gente pensa é sempre na questão da interatividade, para poder navegar, porque ele vai ter mais recurso para fazer isso, mesmo com o smartphone ele vai ter recurso na web.

Entrevistador: No fechamento da edição há aproveitamento de algum conteúdo produzido para outro suporte?

E2: Não, não, mas isso é uma orientação do jornal, o nosso conteúdo é todo exclusivo.

Entrevistador: Existe algum planejamento prévio da arquitetura da informação? Como que essa informação é colocada?

E2: Você diz a pauta, as próprias ferramentas dentro da pauta?

Entrevistador: Da própria navegação do texto.

E2: Tem um projeto gráfico que a gente segue, então matéria tem vários tipos, existe um projeto gráfico por trás disso. A gente tem uma ordem de publicação, que é também a do projeto gráfico.

Entrevistador: Existe uma preocupação com a interatividade desse usuário? Com a interação com o conteúdo?

E2: É o que eu te falei, total, é uma preocupação básica, você tem que interagir com a matéria.

Entrevistador: Existe alguma previsão conteúdo (9:38s - Não dá pra ouvir)

E2: Olha, é o que a gente sonha, por enquanto, até porque a tecnologia pra gente é complexa, a gente não consegue fazer, acho que ninguém consegue fazer muito sem micro, a 
customização é muito simplesinha, né, porque na verdade as edições são muito pesadas, a gente tem um problema que nós mesmos não temos como resolver que é a capacidade das redes em que as pessoas estão conectadas, pra baixar, só um computador profissional que faz isso, tecnológico na verdade, ele é muito menos o seu projeto de idéia, isso é a parte fácil, do que a produção, que leva um custo, não só nosso, de comunicação, pra conseguir fazer isso. Por assim, o cara ta num smartphone, usando um 3G, 4G da vida, não vai interagir com nada, não vai ver nada.

Entrevistador: A própria questão da identificação, do local.

E2: Exatamente, então isso é complicado, tecnologicamente complicado.

Entrevistador: E em termo de memória, você utiliza de alguma forma a memória do que é produzido pela produção?

E2: Não, não, a gente tem, a gente guarda as produções, mas não é muito organizado, a gente procura elas quando lembra, mas o Globo A Mais é muito novo, então a gente só tem as matérias que foram publicadas, mas de forma geral não.

Entrevistador: Há um tamanho aconselhado para a produção dos textos?

A: Não, é o bom senso o tamanho do texto, mas no jornal tem que ter um espaço limitado, tem matérias muito menores, a web como tem o tempo limitado também tem, a gente consegue fazer textos, até porque a nossa proposta, nós somos uma revista, então as matérias são maiores porque é da natureza da revistas é maior, mais analítico. É o bom senso, também não adianta fazer matéria quilométrica que ninguém vai ler, ela pode ser maior.

Entrevistador: Existe uma orientação de quantos textos são postados por dia?

E2: Não, mas é uma limitação que tem a ver com o tempo de edição, a gente publica segunda a quinta em geral uma ou duas matérias e três, quatro colunistas, mais duas matérias menores sobre cultura com recomendações pro Rio, pro resto do Brasil, programas, nós temos uma sessão fixa de fotos, uma sessão de notícias que é o dia, temos uma sessão fixa de história, de imagens históricas. E o de sexta, que é maior porque a gente sabe que o pessoal vai ter mais tempo de fazer o download.

Entrevistador: O processo de produção dos infográficos, o que define, há algum critério?

Editor 2: Aí é o feeling da gente, tem repórteres que rendem infografia e tem repórteres que não rendem infografia, e são os designers que fazem.

Entrevistador: Como é que são escolhidos os arquivos midiáticos, como é que escolho um tipo de mídia em detrimento de outros?

E2: Ah, depende da pauta, por exemplo, a gente está com uma pauta de matéria sobre 
rock, a gente está apostando muito mais nos áudios do que em qualquer outra coisa, então vai depender muito, se você pegar matéria de economia, que você possa ter dados mesmo, que você possa publicar isso, a gente vai tentar simplificar isso para que a pessoa possa navegar de uma forma mais fácil e que ela possa puxar o número que ela quer e navegar com ele. Depende da pauta.

Entrevistador: Quem é que produz esses arquivos midiáticos?

E2: O conteúdo nós mesmos, existem algumas ferramentas que o design disponibiliza.

Entrevistador: O repórter sai com uma filmadora...

E2: Ah, você diz os vídeos, depende, depende da pauta, se for uma coisa muito simples ele sai, se for uma coisa muito elaborada a gente tem o pessoal do vídeo aqui no jornal e aí o pessoal do vídeo produz.

Entrevistador: Desculpa, é uma questão mais logística, como que funciona a redação do Globo A Mais, tem um material mais específico?

E2: Não, não, é do jornal, aí é fotografia do jornal.

Entrevistador: Existe um manual que orienta essa edição desse conteúdo de vocês?

E2: Não.

Entrevistador: Certo, então acaba sendo o manual do Globo.

E2: É, nada específico.

Entrevistador: Mas vocês seguem algum modela na produção textual, modelo quando eu falo é pirâmide invertida...

E2: Não, nenhum, o que fica bom.

Entrevistador: Existe alguma previsão de geolocalização de informação?

E2: Por enquanto não, ela pode agregar em algumas pautas, mas seria em pouquíssimas pautas na verdade.

Entrevistador: Como é que são escolhidas as matérias que ganham destaque?

E2: A gente tem uma durabilidade, o tempo de vida daquela matéria, a gente sabe que não necessariamente a pessoa a lerá a noite, tem gente que lê tudo de uma vez ao longo da semana, então a matéria tem que ter fôlego para sobreviver a isso. A outra coisa é que ela tem que ter valor de notícia, a gente tem que ter uma sintonia muito fina entre o que está acontecendo no dia e o que a gente consegue oferecer a mais, é difícil. E outra coisa que a gente tenta fazer é dar variedade, são poucas matérias, então a gente tem que pensar ao longo da semana numa variedade de pautas.

Entrevistador: Qual o horário do fechamento do Globo A Mais?

E2: A gente começa, ela tem que estar no ar pros iPads, que é a primeira plataforma 
que vai no ar, às 6h30, as outras, em geral o Android vai junto, quase sempre Android e Web seguem juntas, o iPhone é um pouco mais complexo então segue um pouco depois. Porque o iPhone, e aí vale pros outros smartphones, eles não poder ter uma edição tão pesada, então a gente tira alguns vídeos porque se não não vai rodar.

Entrevistador: Houve alguma mudança editorial na proposta do Globo A Mais?

E2: Não.

Entrevistador: Continua valendo o a mais?

E2: Sim, o Globo A Mais é realmente exclusivo.

Entrevistador: Parece que as pautas agora não analisam diretamente o dia, parece que elas estão trazendo coisas diferenciadas.

E2: É isso, a gente procura trazer coisas diferencias, diversos temas, mas quando tem um assunto que eu não consigo ignorar, eleição, copa do mundo, um grande acontecimento no Oriente Médio ou a morte do Eduardo Campos, se você não falar disso você vai parecer um débil mental, porque você não está falando da realidade, então é aquilo que eu estou te falando, tem a sutileza de você fazer uma pauta, por exemplo, de eleição, agora, que ela seja realmente além do que aquilo que o jornal está oferecendo, isso é um desafio, porque o jornal já tem um volume gigantesco de matérias, o site, o impresso, então você ser a mais, uma coisa diferente, que acrescente, é um desafio.

Entrevistador: Bom, eu acho que essa você vai conseguir me responder bem, esse novo ritmo da redação, digital em primeiro lugar, muda alguma coisa na produção dos jornais, no sentido de "olha, agora a Globo priorizou..."

E2: Pra nós não muda porque nós já éramos digital antes do impresso, e por isso a gente tem uma rotina muito diferente, a gente não tem a rotina do resto do jornal, mas a nossa preocupação aí é não repetir o que já está no site, então o site aumenta o desafio, e o site não só é importante como ele importa com volume, pensa em muita quantidade também.

Entrevistador: Certo. Os editores do Globo A Mais tem alguma outra função ou vocês só são responsáveis pelo Globo A Mais?

E2: Só, aí só plantão que a escala é diferente, mas isso vale pra qualquer editor do jornal, todos eles são assim.

Entrevistador: O fato do Globo A Mais ter a sua redação convergente, estar numa redação convergente, trás de alguma forma implicação no processo de produção?

E2: Não, só isso, que a gente tem que estar muito atenta no site e impresso pra oferecer um matéria diferente, um material que tenha muita qualidade, e a diferença de que se a gente não tivesse junto da redação seria que a gente acompanharia isso mais de longe, a 
gente acompanha mais de perto, a gente tem mais interação com as outras editorias, mas é só essa, espacial.

Entrevistador: O Newsgate tem algum papel?

E2: Graças a Deus, nenhum. O design é superior.

Entrevistador: E qual o papel das mídias sociais no processo de produção de vocês?

E2: Nenhum, porque a gente só vai publicar no fim do dia. Eu tava tentando lembrar porque a gente tem um monte de coisa, pra nós não, porque a gente só vai publicar no fim do dia, claro que a gente verificar o que está bombando, o que não está, tem sempre um viés ali, até porque de tudo o que ta bombando nas redes, no Twitter, $90 \%$ é bobagem, então também a gente não vai ter proposta nova mesmo.

Entrevistador: A partir da sua experiência profissional você observa que existe transformação no processo de produção da notícia?

E2: Existe, claro, existe, aqui, é o que eu to te falando, é um projeto novo, é uma experiência nova, a gente está aprendendo a fazer uma coisa, inventando, então não tem parâmetro com quem trabalha com o impresso e quem trabalha com web, mas quem trabalha com impresso, quem trabalha com web, a vida tem mudado radicalmente nos últimos anos.

Entrevistador: Quando auxiliar a produção de um jornal nesse processo convergente?

E2: É porque é separado, né, a nossa produção é separada da deles, eventualmente em algumas matérias tem uma troca, mas não é a regra, e a gente evita fazer isso justamente para que o leitor tenha um material diferente mesmo.

Entrevistador: Qual é a função de um editor no Globo A Mais?

E2: É muito mais assim de pautar, pensar nessas pautas, pensar no que é realmente multimídia, e isso é um desafio, tentar equilibrar isso, segunda tem que ter política, segunda eu vou ter saúde, quarta eu posso ter esporte, economia, tentar fazer um equilíbrio que não canse, que interesse o leitor.

Entrevistador: É interessante que não há uma divisão de editoria desses assuntos.

E2: Não, a gente trabalha com tudo, trabalha separado, mas trabalha com tudo, a gente tem aqui dentro da editoria pessoas com diferentes vivências, a gente tem especialista em educação, no esporte. Mas ter essa experiência não me impede de ver e pensar pautas sobre todos os assuntos.

Entrevistador: Existe alguma orientação para os colunistas?

E2: Eles são 100\% livres.

Entrevistador: E essa questão, às vezes vocês tem alguns arquivos multimidiáticos, vocês são guiados por eles ou não? 


\section{E2: Como assim?}

Entrevistador: Você encontra um vídeo, vídeo de, sei lá...

E2: Um colunista? Ah, ele bota se ele quiser.

Entrevistador: Ele manda?

E2: Ele manda, "ah, to mandando um vídeo", ele manda por email, e ele mesmo toma a iniciativa, eles mandam.

Entrevistador: Certo, então eles mesmos já percebem essas potencialidades.

E2: Sim, e aí eles indicam quando tem.

Entrevistador: Certo. Passa por algum treinamento ou não?

E2: Não, quase todos, todos, são provenientes do jornal, pessoal bem experiente.

Entrevistador: Como são selecionados os repórteres?

E2: Pela qualidade do serviço, interatividade.

Entrevistador: Ele precisa ter esse conhecimento, potencialidade?

E2: Ele precisa não necessariamente ter esse conhecimento, ele precisa ter vontade de ter esse conhecimento. Porque é muito difícil você achar, você acha quem tem experiência em web, mas essa experiência de pensar multimídia, as pessoas não tinham, as pessoas não tem, é tudo recente, então a pessoa tem que ter a disponibilidade de aprender, de saber que ela vai mexer com isso.

Entrevistador: Há algum treinamento que elas passam?

E2: Não, elas vão vendo como os outros trabalham, vai aprendendo na prática.

Entrevistador: E tem algum software que vocês usam?

E2: Não, são ferramentas simples, quem usa mais são os designers, mas aí é diferente, eles tem um treinamento, precisa ter idéia pra usar aquilo, não precisa programar.

Entrevistador: Qual é o papel do editor multimídia?

E2: Eu não programo, mas eu posso pensar, essa e essa forma funcionam bem nessa matéria, eu sei o que eu vou programar, vou pensar com o design, primeiro eu converso com o repórter.

Entrevistador: Há um editor multimídia?

E2: Não, é a gente, não existe editor multimídia.

Entrevistador: Ah, é porque tem um nome 'editor multimídia'.

E2: Ah, não, o editor multimídia, na verdade, é um nome chique, é o editor de vídeos do jornal, ele produz conteúdo de vídeos internos e externos, pro site, mas é mídia.

\section{SEGUNDO ÁUDIO}

Entrevistador: Uma foto sem é publicada no Globo A Mais? 
E2: Não, ela não entra, a não ser que ela seja preciosa, sei lá, histórica... ditadura... você não tira, você pode botar a fotinha depois do...uma porcaria de foto em qualidade, mas aí até a Raquel teve uma ideia ótima de usar uma foto de lente, quer dizer, e a foto ficou bem pequenininha mesmo, ela era um retratinho, mas ela não abria nada, porque nesse caso elas eram realmente a matéria, era fundamental estarem ali, mas senão... A matéria que a gente publicou ontem, de turismo, as fotos se não tivessem resolução, qualidade suficiente pra publicar, a gente não conseguiria fazer a matéria, porque como que a gente faria uma matéria sem foto?

Entrevistador: Ontem pela primeira vez eu percebi que vocês utilizaram foto na capa de arquivo pessoal.

E2: É, aí foi de propósito, porque era justamente as experiências daquelas pessoas, então tinha que ter uma foto das pessoas, e era uma matéria muito pessoal também, Bárbara tinha planejado dessa forma, ela que propôs a pauta, então a pauta já foi conseguida dessa forma, na verdade, porque se não também a gente não usa.

Entrevistador: A questão é por causa da qualidade mesmo...

E2: Mas ela tinha, óbvio, não era uma foto de jornalismo, era uma foto de viagem, mas como ele era álbum de viagem ela cabia nesse contexto.

Entrevistador: Os vídeos também precisam ter essa alta definição?

E2: Também precisam ser bons, a gente só vai colocar um videozinho mais caidinho se ele for um flagrante, se ele for uma coisa muito especial e a falta de qualidade dele seja compensada pela relevância, se não, não. 
Apêndice L - Editor 3 de O Globo A Mais

Entrevistador: Como são sugeridas e quais critérios são utilizados para escolha dos temas que estarão presentes na pauta?

Editor 3: A gente faz uma reunião de pauta semanal, todo mundo tem que trazer pauta, desde os repórteres até os editores. A gente tem uma coisa diferente do resto do jornal, porque a gente cobre tudo, a gente não é setorizado, então todos os assuntos nos interessam, desde que a gente trate desses assuntos com uma nova abordagem, tanto em termos de formato, que aí inclui uma galeria de fotos incrível, um vídeo incrível, matéria de sexta-feira de capa, por exemplo, a última era praticamente só um vídeo, era um texto, mas a matéria foi editada em audiovisual. Ou desde que a gente se proponha a pegar um assunto factual, como eu havia te falado, e trata-lo de uma outra forma, em que a gente consiga fazer uma coisa mais reflexiva, que a gente ouça vários especialistas sobre o tema, coisa que o jornal factual muitas vezes não tem espaço e não tem tempo pra fazer. É mais ou menos por aí, então eu acho que isso que leva a decidir por uma boa pauta.

Entrevistador: Qual é o modelo de pauta que é adotado aqui?

E3: Como assim? Como modelo?

Entrevistador: Existe um modelo fixo? Ela é escrita, ela é oral, como é que funcionam essas pautas?

E3: Existe uma coisa que a gente faz muito, a diagramação, por exemplo, foto grandão, um texto e ao longo desse texto a gente vai salpicando o enriquecimento, seja uma galeria de fotos, seja um vídeo.

Entrevistador: Eu falo da pauta, na reunião de pauta como que faz, alguém trás uma coisa pronta, existe um template, ou as pessoas...

E3: Não, não, na verdade cria um google box, como eu te mostrei, as pessoas vão falando as suas pautas, falando mesmo, às vezes elas nem chegam com a ideia pronta, elas falam tipo "eu vi isso acontecendo, eu queria fazer alguma coisa nesse sentido, eu queria debater", a gente debate, o que é natural mesmo, como no resto do jornal também é, e enquanto as pessoas vão falando a gente vai vendo as pautas e pensando quanto tempo a pessoa precisa pra fazer aquilo. Às vezes ela trás uma coisa que vai ficar pronta em um mês, que é um especial em que vai demandar muito tempo, então a gente vai dosando entre o que a gente acha que tem que ter na pauta da pessoa e o quanto ela tem que se envolver, pesquisar e entrevistar pessoas para fazer.

Entrevistador: Certo, e durante essa reunião, as características dos tablets são levadas 
em conta?

E3: São, muito, cada vez mais, é uma coisa que vem se transformando muito, a gente fica falando "a pauta tem que piscar", ela tem que ter um apelo visual que a gente consiga ter ideias de como estrutura-la além do texto e da imagem estática. Então a gente tem cada vez mais pensado nisso, às vezes uma pauta que não rende tanto com gráficos, infográficos, essas coisas, que ela acaba até se destacando e virando uma pauta e ela vira uma coisa ótima, exatamente porque ela já vem dentro das características do tablet, ou enfim, da onde a pessoal estiver lendo.

Entrevistador: Quem participa dessa reunião?

E3: Os repórteres, os editores e normalmente um dos diagramadores vem também, porque eles dão ideias pro formato e às vezes eles dão sugestão de pauta, e eles dão pitaco, é uma equipe bem, por mais que a gente tenha condições diferentes, no final a gente se entende, porque a gente dá pitaco no deles, eles dão pitaco no nosso, está tudo meio junto.

Entrevistador: Há alguma avaliação de métricas tanto do portal, como dos outros suportes, do grupo pra escolha do tema que será abordado na pauta?

E3: Não, nesse sentido não, a gente tem uma avaliação de métricas sobre quantos downloads tem sido feitos, quantas pessoas veem, mas não fazem download, isso a gente tem.

Entrevistador: Isso influencia na hora da decisão da pauta ou da escolha dos temas?

E3: Não, que eu tenha prestado atenção não, mas eu to aqui faz 5 meses, porque pauta boa é pauta boa, enriquecimento bom de matéria é enriquecimento bom, é claro que a gente espera que aquilo tenha o máximo número de downloads possível, mas a gente também trabalha jornalisticamente o que é relevante.

Entrevistador: Eu vou fazer uma pergunta meio básica, bom, as mídias sociais tem alguma influencia na construção dessa pauta?

E3: Tem, não no sentido de o que é nosso vai fazer sucesso nas redes sociais, mas sim no que as redes sociais estão falando, eu vejo muitas coisas, sou meio viciada, e isso acaba refletindo na reunião de pauta, "tá todo mundo no Facebook falando sobre isso", e aí a gente desenvolve alguma coisa não em cima do que as pessoas estão falando, porque se não vira uma rede social e pronto, mas como isso pode se transformar numa matéria, numa coisa interessante, relevante, que faça diferença pro leitor.

Entrevistador: Os repórteres vão à campo apurar e cobrir eventos ou fatos?

E3: Vão, as meninas, por exemplo, ontem foram à Universal, segunda vez que a Renata já foi pra uma igreja dessas, essa matéria está demorando muito, eu mesma na segunda-feira fui fazer uma matéria com uma menina que está presa, fui lá no presídio 
feminino, a gente vai sempre que necessário, e muitas vezes é. É um trabalho de reportagem normal, mas também tem muita pauta que a gente faz por aqui porque são entrevistados de cidades estrangeiras, fotos que eles mesmos nos mandam, então a gente consegue resolver algumas coisas por telefone.

Entrevistador: Quais são as ferramentas que são utilizadas nesse processo de produção?

E3: De produção de reportagem?

Entrevistador: Isso.

E3: Câmara fotográfica, gravador, é isso?

Entrevistador: Tudo, na verdade, por exemplo eu vi você usando indesign.

E3: É, tecnologia, repórter, fotógrafo, o fotógrafo muitas vezes faz vídeo pra gente, por exemplo, eu fiz vídeo na segunda-feira com a menina que está presa que é o fotógrafo que faz, eles estão preparados pra isso. A gente também faz quando, as meninas fizeram foto agora, a gente faz foto, normalmente pra capa não, a gente faz fotos pra dentro, fotos que possam ajudar a contar aquelas histórias, a gente pode fazer vídeo também, tem uma equipe de edição aqui embaixo pra usar, é isso.

Entrevistador: Vocês utilizam alguma base de dados pra apuração?

E3: Depende da matéria, enfim, o que a matéria demandar. A gente tema gora uma editoria de dados aqui no jornal, que é o Pablo Vasconcelos que coordena, porque a última matéria que eu me lembro de ter chegado nele e falado "preciso de ajuda, vem cá", foi uma matéria que a gente fez sobre a atuação dos candidatos ao governo do Rio nas redes sociais, e eu fiquei fazendo na mão uma tabela de excel, que aí eu fiz uma análise de uma semana de cada candidato no Facebook, quantos posts, quantas curtições em média, eu fiz as contas de tudo, e ele me ajudou a organizar esses dados e me mostrar onde eu poderia achar outras coisas, enfim, mas é só quando a matéria demanda mesmo.

Entrevistador: Os repórteres recebem alguma orientação no sentido das características do tablete pra própria construção da informação ou está todo mundo já muito orientado, a coisa está muito clara?

E3: Não, porque a coisa vai se construindo, assim, tem coisas que a gente faz sempre, maneiras de apresentar aquela matéria que são recorrentes, galeria de fotos é uma coisa recorrente, mas sempre que alguém vê uma coisa nova, não só o editor, mas também o repórter, trás isso e a gente vê que não tem muito modelo, não tem um modelo do jornal que serve pra isso, então a gente está meio que criando. Agora no fim de semana a gente deu um especial sobre o Ted Rio, conversando com repórter, que nem é repórter daqui dessa editoria, 
é de outra, que estava cobrindo tag, ele mesmo falou "eu queria tentar fazer pro Globo A Mais uma coisa que não dá pra fazer pro jornal", ele falou "assisti todas as palestras e queria fazer uma coisa meio no formato tag, ideias, pílulas soltas", eu falei "então vamos lá, vamos fazer uma nuvem de tags, com 20 ideias que você acha relevante da gente contar, e pra cada coisinha que você clica a ideia vai pular na tela", e a gente fez, entendeu? E é uma coisa que a gente não faz muito, não é comum no dia-a-dia, então, às vezes o repórter chega com uma ideia e aí a gente tem que perguntar pro diagramador se dá pra fazer, nem sempre dá porque hoje o sistema não permite, mas é isso.

Entrevistador: No fechamento da edição há aproveitamento de produtos pra outros suportes?

E3: Não mais, antigamente tinha, antigamente a gente usava matérias que iam sair no jornal no dia seguinte e a gente dava uma nova roupagem, depois de um tempo perceberam que não era um objetivo do jornal. Então, não, a gente faz coisa exclusiva pra cá e depois o que a gente faz pra cá vai pro site, mas não vai pro papel.

Entrevistador: Vai pro site com a mesma roupagem ou eles trabalham?

E3: Não, não vai com a mesma roupagem, é texto e foto, e vídeo quando tem, mas essas brincadeiras todas não, e tem que sair depois, depois que sair, na edição do dia seguinte é que sai no site, entendeu?

Entrevistador: Existe algum planejamento prévio da arquitetura da informação? Essa coisa da navegação é pensada anteriormente?

E3: Ela já foi pensada dentro do modelo do Globo A Mais, então a navegação do Globo A Mais foi pensada de você postar as páginas assim, de você fazer uma matéria assim.

Entrevistador: Mas e se você for fazer uma matéria hipertextual, se quiser inserir link, alguma coisa...

E3: A gente insere muito link, assim, vou contar uma experiência minha, é que eu me imagino como leitora, se eu vou entender isso, se eu vou me cansar lendo isso, se isso vai fazer sentido pra mim. Por exemplo, outro dia a gente fez com o Mateus, a gente estava fazendo uma matéria que era cartoonistas que desenhavam de olhos abertos e depois eles vendavam os olhos e desenhavam de novo pra ver como que saiam os desenhos, e aí a ideia inicial era de fazer uma coisa de "raspadinha" que a gente chama, né, quando eu vi pronto, a raspadinha apesar dela ter um recurso maravilhoso ela não tava funcionado porque o preto e branco, um dia eu vou te mostrar pra você entender, como leitora eu falei cara, eu ia ficar confusa, eu não ia saber quando que eu ia ter que parar de fazer a raspadinha, prefiro uma coisa que você clique e eu mostre uma coisa, entendeu? É meio assim que eu vou me guiando, 
e às vezes eu vou até pras pessoas “isso faz sentido pra você?”, porque você está tão em cima disso que você para de pensar se aquilo é bom ou ruim porque já é familiar.

Entrevistador: Então não há uma coisa pré-estabelecida pra inserção de hipertexto, é uma coisa que o repórter decide...

E3: Quando ele é necessário, quando ele faz sentido, o hipertexto ele vai ser sempre necessário se você está falando muito dele na matéria, não adianta você falar muito se a pessoa não puder ver aquilo, normalmente a gente usa link de site, então se eu estou falando que a palestra do Ted foi linda, maravilhosa e tal, pô já tem link da palestra do Ted porque eu vou ficar falando aqui sendo que o cara já pode clicar e olhar, entendeu? É isso.

Entrevistador: Existe alguma preocupação com a interatividade do usuário?

E3: Interatividade no sentido de interação dele com o produto?

Entrevistador: É, qualquer interação.

E3: É, é sempre necessária, não há uma matéria em que ele não brinque, que ele não escolha alguma coisa pra fazer ou um caminho.

Entrevistador: Não sei se vocês já discutiram ou se existe alguma previsão de individualização de conteúdo, conteúdo pensado pra determinado tipo de usuário do Rio de Janeiro, por exemplo.

E3: Que eu saiba, mas eu estou aqui há pouco tempo, que eu saiba não, mas provavelmente alguém já pensou e alguém já falou sobre isso, principalmente na construção do projeto.

Entrevistador: Vocês utilizam algum tipo de memória do que foi produzido, do que existe?

E3: Do Globo A Mais ou do...

Entrevistador: É, do Globo, do Globo A Mais, da memória do que é produzido por vocês. Como é que vocês tem acesso ao que vocês produzem?

E3: A gente tem um arquivo interno, os leitores não tem acesso, uma vez que saiu do ar, saiu do ar, a gente tem uma biblioteca de 30 dias anteriores. A gente usa toda vez que a matéria pede que a gente relembre coisas que a gente mesmo já fez ou que o jornal já fez, é dessa forma que a gente usa a memória.

Entrevistador: Há um tamanho aconselhado pro texto?

E3: Tem, na verdade não é um tamanho médio, a gente tem um tamanho máximo, e a gente brinca, porque alguns repórteres às vezes extrapolam, tem uma moça que era repórter aqui e ela é ótimo, e ela escrevia muito e a gente fala muito que quando um cara está fazendo uma matéria muito grande que está fazendo uma matéria do tamanho que ela fazia. Mas tem 
um tamanho médio, eu não sei te precisar agora como ele fica, mas é que dando o scrow (14:16s - Conferir o termo) a gente tem já a noção do tamanho, quando é muito grande e quando não é.

Entrevistador: Existe alguma orientação de número de textos publicados? A edição pode crescer?

E3: Pode, mas a gente tem de segunda a quinta uma matéria de capa, duas dicas, três a quatro colunistas, giro...

Entrevistador: Vamos dizer que você tenha duas grandes matérias no dia, é possível?

E3: Pro mesmo repórter não, ele vai estar fazendo uma grande matéria, sexta-feira é que a gente dá três matérias, a capa mais duas, mais quatro colunistas, mais o giro, mais as imagens do dia, mais as escritas, porque a gente acha que o leitor vai ler ao longo do fim de semana, então sexta-feira é um dia que dá pra aumentar a edição.

Entrevistador: E a construção dos infográficos, como é que você decide que vai ter um infográfico no trabalho, e quem é responsável pela construção?

E3: Como você decide, é quando jornalisticamente aquela matéria está te pedindo um infográfico, agora mesmo eu estou fazendo essa matéria sobre essa menina, eu liguei pro IBGE, eu precisava de dados, pra tentar localizar aquela menina dentro do universo das pessoas da idade dela, então escolaridade, taxa de fecundidade, faz todo sentido porque a minha matéria é sobre a menina e sobre pessoas da idade dela, fazendo uma comparação infográfica. Ele vai existir quando ele for necessário, não vou tirar o infográfico da cartola porque vai ficar ridículo. Eu vou começar a construir esses gráficos com os próprios diagramadores que já tem os templates e algumas coisas, e constroem outras coisas pra gente também.

Entrevistador: Como é que são escolhidos os arquivos muitimidiáticos? O que faz você levar em conta? Por que você usaria um vídeo e não um áudio?

E3: Duas coisas, uma é o sentido e a relevância daquilo, outras vezes é o material que representa que existe, então se você estiver entrevistando uma pessoa e ele for fotógrafo e ele tiver fotos incríveis, você faz uma galeria de fotos, entendeu? A matéria vai meio que te dizendo e a própria pessoa quando você estiver entrevistando ou você for encontrando no caminho que achar um material bacana e falar isso, isso, isso.

Entrevistador: Alguma matéria pode ser inviabilizada pela ausência desses arquivos?

E3: Nunca vi isso acontecer porque a gente sempre conseguiu, mas capaz, eu acho ruim uma matéria que tenha só texto corrido, foto estática, porque isso é o que se apresenta no jornal, não dá pra ter isso em uma revista digital, então a gente sempre tenta, na medida do 
possível, ter alguma coisa diferente.

Entrevistador: Vocês seguem algum modelo de produção textual? E quando eu vou falar de modelo eu estou falando, por exemplo, da pirâmide invertida.

E3: Na verdade é o texto do jornal mesmo, é como se eu estivesse escrevendo pro jornal só que eu estou escrevendo aqui. Pro dia-a-dia, pro factual, a pirâmide invertida e as perguntas acabam se refletindo pra falar sobre o que aconteceu e tal, nas matérias que a gente faz, como elas são mais elaboradas e elas não estão focadas no factual, elas...

Entrevistador: Não necessariamente vão seguir...

E3: É, o que importa é que é uma excelente apuração, normalmente quando eu vejo uma matéria eu procuro o máximo de pessoas que me deem o máximo de informações para aquela matéria ser consistente, acho que isso que faz a diferença no texto.

Entrevistador: Existe alguma manual que vocês utilizam pra edição de conteúdo?

E3: Manual de redação do Globo, ele serve pra todo mundo que trabalha aqui, a gente não é diferente do jornal, a gente segue as mesmas regras, tanto ortográficas, quanto textuais, estilo e tudo, é o manual de redação.

Entrevistador: Como são escolhidas as matérias que ganharão destaque? Você mais ou menos já respondeu.

E3: É, pela reunião de pauta a gente vê o que que rende capa, o que que rende matéria interna, o que vai dar mais conteúdo interativo, a gente vai pensa "espera aí, essa matéria vai ganhar capa".

Entrevistador: Qual é o horário de fechamento?

E3: Seis da tarde.

Entrevistador: Esse novo ritmo da redação, essas coisas digital, mudou alguma coisa na produção do Globo A Mais?

E3: Muda, porque a gente, assim, tem muita coisa que sai no jornal e que, obviamente, é do jornal, e muito coisa que sai no site e acaba sendo do site, então a gente tem que se diferenciar desses dois produtos muito intensos e muito ligados ao que está acontecendo no dia-a-dia. A gente segue os dois pra saber o que está acontecendo, mas ao mesmo tempo a gente tenta fazer uma coisa diferente.

Entrevistador: Além do Globo A Mais você escreve pra outra plataforma ou tem algum repórter que faz isso?

E3: A Ana Lúcia é responsável pelos e-books que o jornal lança, que o jornal já lançou alguns de grande reportagens ou projetos especiais, e só, é isso.

Entrevistador: E você pensa em alguma outra ou você só trabalha... 
E3: Aqui, só trabalho aqui.

Entrevistador: O fato do Globo ter a sua redação convergente trás alguma implicação no processo de produção de vocês?

E3: Trás, no dia que o Eduardo Campos morreu foi emblemático, a gente conseguia ver a movimentação, principalmente da capa do site, do site, pra pensar, produção, você via as pessoas gritando aqui, gritando no bom sentido, né, "olha, agora vai ser isso", então a produção deles acaba afetando diretamente o que a gente está fazendo, principalmente se a gente está em uma notícia mais quente, assunto do dia.

Entrevistador: Qual o papel dos newsgate na produção?

E3: A gente não usa newsgate aqui, a gente só usa para checar coisas, e isso faz um pouco com que seja difícil a gente absorver pessoas da redação às vezes aqui, porque as pessoas tem que estar muito familiarizadas com o design e vice-versa, a gente não usa o newsgate no Globo A Mais, a gente usa o Windesign pra subir direto pra plataforma.

Entrevistador: Mais uma dúvida, o newsgate não controla o fluxo da redação inteira?

E3: Sim, mas o nosso não.

Entrevistador: Então vocês utilizam, não sei se ainda existe, o "Tá quente”?

E3: Eu leio todo dia, me interesso muito, mas o Tá quente ele acaba sendo dividido muito entre as editorias, elas vão vendo o que tá rolando. Eu uso o Tá quente muito pra saber o que está sendo falado nas redes sociais, e às vezes isso me dá uma ideia de pauta, não necessariamente o que é, o que está quente, mas é porque o está quente pode desenvolver, aonde ele pode levar, me lembro de uma pauta que já rolou uma vez, eu também vivo no Tá quente, vivo na rede social, mas era um cara que compartilhava fotos, que era fotógrafo, da filha dele, um americano, ele estava numa viagem e algumas fotos ela aparecia sem roupa, tem dois anos, isso criou uma bagunça nos EUA muito grande, do que esse pai podia fazer, eu não quero fazer uma matéria do pai, essa matéria já saiu, eu quero fazer uma matéria debatendo até que ponto a gente pode colocar fotos dos nossos filhos nos sites, então eu vou procurar vários brasileiros pra fazer, o Tá quente pode me ajudar nesse sentido.

Entrevistador: A partir da sua experiência profissional você observa que existem transformações no processo de produção da notícia no contexto dessa redação convergente?

E3: Sim, repete a pergunta só pra eu formular melhor a resposta.

Entrevistador: A partir da sua experiência profissional, você observa que existe transformação no processo de produção da notícia nesse contexto de uma redação convergente?

E3: Existem, existe, eu tava assim pensando jornal com base também no que já saiu na 
internet, então o jornal de amanhã, como quando eu comecei na profissão não era assim, tudo bem que praticamente não tinha internet na redação, mas assim, não adianta você sair no jornal de amanhã dando uma notícia que já foi super mastigada no dia anterior, se não você parece um velho vovô, no mal sentido de vovô, “espera aí, amigo, todo mundo já falou, o que mais tem? Onde avança a partir daí? O que de mais profundo você pode me dar a partir do que já aconteceu?", muda nesse sentido.

Entrevistador: E a partir disso você acredita que o Globo A Mais acabe impactando no processo de produção da notícia das outras formas?

E3: Eu espero que cada vez mais, eu acho que as pessoas ainda ficam muito concentradas no papel e no site, muitas pessoas não tem tablet, muitas vezes porque já demanda muito tempo, mas eu acho que cada vez mais as pessoas olham principalmente o formato pra falar "nossa, que ideia legal", "ah, que maneira de interagir legal”, porque o jornal não consegue fazer essa interação, mas vai que isso te dá uma outra ideia de diagramação da sua matéria, pra mostrar a sua matéria de uma maneira diferente, não sei eu espero que isso seja crescente.

Entrevistador: Como conciliar e pensar a produção de uma edição de um jornal nesse contexto?

E3: É cansativo, é desafiador, eu tenho que pensar por onde eu posso sair, para onde eu posso sair, e ainda em como ser procurado pelo leitor, por que o leitor vai querer me ler num mar de notícias, pessoas, repórteres, é difícil, mas é compensador quando você acaba fazendo sucesso.

Entrevistador: E aí agora são perguntas mais relacionadas à você, profissão mesmo, à você equipe. Qual é a sua função aqui?

E3: A minha função, eu acabei meio que pegando pra mim, eu faço meio que chefe de reportagem, eu sei exatamente o que os repórteres estão fazendo, quem pode pegar o que, quem pode fazer o que, eu tento fazer isso sempre, tanto quanto colocar as coisas lá no calendário. Eu ajudo no fechamento quando eles precisam, eu vou ajudando, mas eu faço reportagem, então eu fico meio transitando em vários meios.

Entrevistador: Você falou dos colunistas, existe alguma orientação na produção desses conteúdos? Eles são orientados de alguma forma?

E3: Não, eles são livres, como todos os colunistas na verdade, eles já tem assuntos que eles mesmos escolheram abordar, assuntos que eu digo grandes temas, então você tem uma colunista falando mais sobre culinária, você tem a Adriana, que é nossa colunista também, que fala muito sobre tecnologia no dia-a-dia, o Agustinho Vieira que fala muito sobre verde e 
sustentabilidade, a Ana que tem uma coluna sobre esporte e corrida, que é a praia dela, então cada um já tem a sua área e eles escrevem...

Entrevistador: Como eles são escolhidos?

E3: Pela relevância que eles têm dentro do jornal, por tudo o que eles já fizeram, bons jornalistas, ótimos textos.

Entrevistador: Como que os repórteres são selecionados?

E3: Eu nunca selecionei nenhum repórter pra vir pra cá, porque eu estou há pouco tempo, mas muitas vieram pra cá jovens, vieram também como treinees e se deram bem, foram ficando, reformaram a equipe.

Entrevistador: Você acredita que existe competências básicas pra atuar aqui?

E3: Como em todo jornal, texto bom, boa apuração, saber que a qualquer hora você pode trabalhar em qualquer coisa, e ser chamado pra qualquer coisa, porque isso é a vida do jornalista, estar disponível.

Entrevistador: E por você estar trabalhando em um suporte que é multimidiático, é diferenciado isso?

E3: Eu acho assim, eu to falando uma coisa que eu posso estar enganada, mas gente jovem é muito bom, mais juventude, não só de idade não, mas de que você se interessa por tecnologia, isso também faz você meio jovem pra esses gadgets todos. Então pessoas que não tem medo de fuçar, que são super curiosas em termos tecnológicos, são ótimas pro Globo A Mais.

Entrevistador: Perfeito. Mas eles passam por algum treinamento?

E3: Capaz que sim, você tem que passar pelo treinamento do Windesign inteiro, e não sei te dizer muito mais não.

Entrevistador: Ok. Eu não sei se você teria como me responder, mas quais são as competências pra um editor multimídia?

E3: As competências do editor multimídia, ele é um editor como um editor de jornal, ele tem que pensar primeiro na relevância daquela notícia para aquele leitor, mas ele tem que pensar também, e isso eu já sugeri aqui, eu acho que a gente tem que fazer quando a gente conseguir tempo, porque não são reuniões só de pauta, como a gente faz pra discutir sobre as pautas, mas reuniões de formato, de cada um sentar e falar "eu tive uma ideia de uma matéria que pode se apresentar assim", "eu li uma revista italiana que se apresentava assim", entendeu? Pra você se inspirar, não pra copiar o que os caras estão fazendo, mas saber que existem outras formas de mostrar aquela mesma notícia, então eu acho que o editor tem que pensar nisso. 
Apêndice M - Editor 1 do Zero Hora

Entrevistador: Qual é a função da pauta no jornal ?

Editor 1: A pauta ela... neste ambiente do jornal marca, né?! No jornal, com presença em mais de uma plataforma. A pauta ela é uma espécie de fio condutor. Ela é um bichinho vivo, ela nunca tá pronta, ela tá sempre mudando. Em alguns momentos do dia, a gente tem momentos de parar para pensar e ver como ela está. Mas ela é um fio condutor tanto da jornada de quem produz o conteúdo, quanto de quem acessa o conteúdo. E ela necessariamente é um ente vivo que tem que tá toda hora mudando, toda hora sendo espancada, toda hora sob judice para que ela se adapte aos fatos do momento e ao mesmo tempo à missão que a gente tem como marca, de produzir conteúdo interpretativo, de produzir tendência, de dar furo, de ter o breaking news, de ter um pacote de $360^{\circ}$ de formatos de notícia, tanto no aspecto do sujeito acessar o conteúdo, do jeito certo... Ele tá lá no formato certo, naquela plataforma, quanto formatos desde 140 caracteres até matérias de dez, doze, quinze, vinte páginas, tentando ampliar uma discussão. Então, a pauta é esse fio condutor, é a espinha dorsal do trabalho da redação. Ela é muito diferente do que era uma pauta quando o jornal era aquele organismo estático com um deadline, que poderia fazer uma pauta e se conduzir por aquela pauta tal qual ela foi pensada $24 \mathrm{~h}$ antes, $12 \mathrm{~h}$ antes do deadline, sem uma margem muito grande de ajuste, de mudança. O jornal sempre foi uma coisa nervosa, mas agora ele é muito mais nervoso porque ele não é mais um jornal né?! Ele é uma usina, a redação é uma usina de produção de conteúdo em diversos formatos, em diversos tamanhos, para diversas plataformas, em diversos níveis de profundidade de leitura, com diversos tempos de produção, com muitas coisas sendo feitas simultaneamente. Então a pauta é aquele farol, assim... "vamos por ali, vamos por aqui. Opa, mas há meia hora eu olhei e era para fazer assim e agora já... Quem é que mudou a pauta?”... Bom, quem mudou a pauta foi o mundo, mas alguém, um produtor, um editor, um coordenador de produção se encarrega de trazer para dentro da pauta isso, né?!

Entrevistador: E qual é a função da reunião de pauta?

E3: A reunião de pauta é, eu acho que é... essa reunião que a gente faz às 09:30, ela é a grande bola ao centro, ela é a grande paradinha para pensar, né?! Então o que a gente faz aqui? A gente constrói a chamada “jornada de publicação de conteúdo”. Isso é uma novidade, tem, sei lá, dois meses que a gente faz nesse formato. Ele tá longe de ser do jeito que a gente quer, né?! Mas essa jornada ela tem que ser construída a partir de dois referenciais: um é a vida real, o que tá sendo produzido, o que está acontecendo, quando podemos publicar tal 
coisa, quando devemos publicar tal coisa porque se não publicarmos estaremos atrasados. E o outro é o comportamento do leitor acessando os conteúdos. Se sabemos que o digital, seja o app, seja o site web, seja o site mobile... Se sabemos que as pessoas procuram essas plataformas para ler assunto x em determinado horário, convém que a gente produza para aquele determinado horário. Se sabemos que no device celular (?) ele gosta de ler assim, é melhor que a gente publique o conteúdo assim. Então a reunião de pauta é o lugar para onde vem para cima da mesa tudo isso, os insights do dia, o que está acontecendo, quais são os fatos, o que não podemos deixar de publicar e o que nós decidimos que vamos hoje publicar, né?! As ideias que temos de abordagens e de outro lado qual o melhor momento de publicar e qual melhor formato de publicar, levando em conta o comportamento de leitura das pessoas. Então, a reunião de pauta é isso, é o momento que a gente mais para para pensar essas duas coisas. Você tá acompanhando já há dois dias a reunião, você vê que eu pouco... a gente pouco pensa... "não, mas pera aí, não publica isso nesse horário porque as pessoas, segundo os nossos indicadores de audiência, as pessoas estão lendo tal assunto mais às 20 horas"... A gente não está fazendo isso ainda, a gente só está distribuindo os conteúdos de uma maneira que caiba na nossa capacidade de produção e de uma maneira que a gente publique na hora certa em relação ao tempo da notícia, ao tempo do fato. A gente agora, em algum momento, vai agregar a isso uma inteligência de leitura do comportamento de consumo de notícias para a gente realocar. Tipo assim... "não, mas porque que essa matéria de análise da redação do ENEM vai ser publicada tal hora? Ah, porque fica pronta tal hora!’... Hoje vale isso, mas daqui a pouco a gente quer assim: "Não, mas espera um pouquinho, isso não é factual. Isso não é resultado de uma reunião. Nós não corremos riscos de sermos furados por ninguém e sabemos que as pessoas leem esse tipo de conteúdo, um pouquinho mais denso, ligado aos filhos, às 20 horas. Então vamos publicar às 20 horas.... Ah, mas isso é uma afronta porque existe escrito nas estrelas uma premissa de que as coisas que são prontas são publicadas.".... Nós não estamos afrontando nada, só estamos tentando conciliar duas coisas que é o tempo da notícia, o tempo da capacidade de produção da redação com o tempo de quem acessa a notícia. Com o objetivo de que, ao final, o máximo de pessoas nos leia. E isso seja bom para a gente, né?! Jornalista vive de audiência, gosta que as pessoas leiam, não gosta de escrever para as paredes, não gosta de falar para as paredes. E que isso funcione para a estratégia de assinatura do jornal, cuja premissa principal é assim: ter pessoas que assinem, que paguem para acessar, que gostem do que leem e que leiam muito, que consumam muito para justificar até o fato de estarem pagando. A reunião de pauta é assim: parou, faz todo um olhar do dia, tenta encaixar em uma lógica de produção, no futuro vai tentar encaixar também em uma 
lógica de acesso das pessoas.... Concilia a capacidade de produção, faz pacto entre as editorias... "Ah, tenho uma matéria muito pesada aqui, essa editoria não tem gente suficiente. Traz alguém daquela outra editoria. Ah, mas as duas matérias fortes de duas editorias vão ser publicadas no mesmo horário ou as duas que são potenciais manchetes vão ser publicadas na mesma edição? Não, então remaneja. Puxa pra cá, puxa pra lá”. O objetivo da reunião de pauta é esse: uma convergência grande pra gente tomar macro decisões, que estão sujeitas a mudar ao longo do dia, mas que são um vetor, são um norte para as editorias atuarem, tipo assim, nas próximas 24 horas. Daqui a 24 horas tem outra reunião.

Entrevistador: Eu não sei exatamente se está na sua fala, mas me parece que a pauta tem uma função organizativa e dentro dessa perspectiva organizativa existem assuntos que têm uma hierarquia maior do que a outra. Existem hierarquias entre eles?

E3: É, o outro objetivo que a gente não está...humm...não é que não está, mas não está plenamente alcançando ainda na reunião de pauta, é que a gente traga para a reunião de pauta, preferencialmente, os três grandes assuntos do dia. Então, por exemplo, hoje, na nossa reunião de pauta, os resultados do ENEM e ainda o pós-eleição. Esses seriam os dois grandes assuntos do dia. Não lembro de nenhum outro assunto que hoje tenha competido. E aí a gente, como a gente usa o jargão, a gente espanca bem esses assuntos. Tenta tirar o máximo deles, tenta ver qual é a melhor abordagem, qual é a mais original, o que tem mais a ver com o nosso leitor, né. Então, isso seria um outro objetivo da reunião de pauta que em parte responde, assim, a tua questão.

Entrevistador: É....não era muito mais tentar entender dentro de um papel organizativo da pauta, se existiriam hierarquias entre os assuntos que são tratados.

E3: Então, a hierarquia seria por aí. Quer dizer, uma base de construção da hierarquia seria isso, que a reunião de pauta tem um ritual. No começo dela é olhar a audiência, a audiência digital, ver os recados que a audiência digital nos dá, ver se em função dos recados da audiência digital a gente tem que remanejar algum planejamento que as editorias já trazem, se algum assunto que tá fora do nosso radar tem que entrar e se algum assunto que tá dentro tem que sair. Ah, nesse caso a audiência não é a deusa todo-poderosa, ela é um dos referenciais que a gente pode olhar e dizer assim: "ah, tá dando uma enorme audiência que o ator tal"... Esquece. Não é isso... O que vai nos determinar é porque temos uma linha editorial que é essa. Então, a reunião de pauta, sim, hierarquiza e a pauta, sim, hierarquiza. E o ideal é que a gente hierarquize a partir de três grandes temas, pode ser quatro ou pode ser dois, do dia e que a gente valorize e invista mais nesses assuntos.

Entrevistador: E essa hierarquia pode ser alterada, tipo, eu tenho a pauta e tenho a 
reunião de pauta. A reunião de pauta pode alterar a hierarquia da pauta?

E3: Pode. A reunião de pauta, na verdade, referenda a hierarquia ou ela muda a hierarquia. E cinco minutos depois da reunião de pauta, se acontecer alguma coisa, de novo a gente muda a hierarquia. Aí, como é que a gente muda a hierarquia? Volta todo mundo para a sala? Não, a gente faz uma discussão ali entre editores e diz: "não, derruba isso, não vai ser mais assim"... Ou então esse assunto que a gente ia tratar com esse viés... ENEM, vamos dizer assim... Ah, o assunto do ENEM era assim. Sem ter os resultados na mão a gente achou que era... “Como foi o Rio Grande do Sul na redação?”... “Como foi não sei o quê”.... Aí sai o resultado do ENEM.... o pior ano de redação da história do ENEM. Bom, então muda a pauta. “Ah, mas porque a gente não decidiu isso na reunião de pauta? Porque a gente não sabia".... Então, a reunião de pauta constrói a hierarquia a partir dos insights que as editorias trazem e as editorias também têm as suas dinâmicas de reuniões. Cada editoria tem uma grande reunião semanal. Todas as editorias em um determinado horário do dia param os editores para conversar. Todos os dias temos também a reunião das 17:30, que também tenta ser um balizador do dia seguinte. Então é esse moto-contínuo, desse moto-contínuo sai uma hierarquia do dia, que é referendada ou mudada na reunião de pauta. E ainda assim essa hierarquia da reunião de pauta pode mudar a qualquer momento se fatos novos acontecerem.

Entrevistador: Quem participa dessas reuniões e por quê?

E3: A reunião de pauta das 09:30, a gente divide a redação em quatro grandes grupos de produção de conteúdo: esporte, cultura e entretenimento - que a gente apelidou de segundo caderno, que é o nome do nosso caderno - , sua vida - que é mais comportamento, estilo de vida - e notícias, que é mais breaking news, mais hard news, não é nem breaking news. Então as reuniões de pauta, que eu coordeno, tem um representante de cada editoria, tem um coordenador de produção de toda a redação, que é o Rodrigo, que tenta organizar e tenta ter uma visão geral, faz a pauta, interage com outras áreas e sai da reunião com missões. Tem um representante da editoria de imagem, que é foto e vídeo. Tem um representante da editoria de arte, que é arte papel e arte digital. Tem um representante de redes sociais, que é muito forte a nossa atuação em redes sociais, a gente precisa de redes sociais. É uma área que tem que estar sabendo de tudo o que acontece. Basicamente é isso. Basicamente são esses representantes.

Então a gente diz assim: a reunião de pauta tem as editorias produtoras de conteúdo e as editorias meio, que são arte, redes sociais e imagem. Essas editorias fornecem insumos para as outras editorias. Elas não resolvem a vida delas. A editoria de imagem não faz a foto do nada, ela produz foto e vídeo vinculados à pauta, vinculados ao que as editorias de 
produção de conteúdo fazem.

Entrevistador: As editorias meios podem interferir, de alguma forma, no processo de produção?

E3: Podem. Totalmente. Elas podem ou pela opinião individual de um editor ou porque lá nos radares delas, elas estão vendo que tal assunto está muito forte ou tal assunto é velho e a gente tá apostando em um assunto velho. Ou porque, sei lá, a fotografia... o fotógrafo saiu para fazer alguma coisa e no caminho achou uma coisa sensacional e aí trouxe para a reunião para a gente produzir uma matéria em cima, dar um suporte para essa imagem. As editorias meio têm um protagonismo.

Entrevistador: Até pouco tempo, a gente tinha somente a participação de jornalistas nas reuniões de pauta. Com a chegada do digital, você começa a perceber que designers, programadores começam a atuar com mais força no processo de produção. Esses profissionais tendem a interferir de alguma forma ou a cultura profissional deles tem algum impacto na nossa produção?

E3: Eles interferem de várias maneiras. Aqui a gente teve um caso clássico disso. A gente sabe que buscador de ENEM é uma commoditie, que todo mundo tem, mas a gente precisa ter. No melhor dos mundos, a gente deveria ter um buscador de ENEM disponível, no site, já assim que os resultados do ENEM fossem disponibilizados. Por uma questão de programação, por uma questão x e y, a gente só vai ter um buscador de ENEM às seis da tarde, que é horrível, terrível, catastrófico. Então, essa é uma intervenção de uma área... do tempo de produção de conteúdo... não é jornalístico, não é nada. Nós não vamos publicar o buscador de notas do ENEM às 18 horas jornalisticamente. Mas foi uma situação motivada por uma circunstância de uma área. Da mesma forma, um briefing que vai para a editoria de arte e que resulta em uma proposta de uma infografia maravilhosa, pode determinar uma mudança de construção de um conteúdo. O conteúdo vai ser feito a partir da infografia, não precisa de muito texto, diminui o texto... Vamos chamar por isso, nas redes vamos chamar isso e não aquilo. No papel nós vamos inverter. Esse assunto ia ter meia página no papel, agora ele vai ter duas porque tem uma infografia, uma ideia de infografia muito legal que precisa de uma página. Da mesma forma a fotografia, o vídeo. O vídeo pode estar tão legal que a gente muda uma hierarquia de tempo, antecipa a publicação desse vídeo, faz uma matéria para sustentar esse vídeo. A pauta era A, mas veio uma imagem B que é muito mais legal e isso está nos sinalizando que nós estamos errando na pauta, o viés da pauta é outro. Então, a capacidade de interferência para o bem, para o mal de áreas que não são genuínas, assim, jornalistas... editores, que são designers, que são programadores, que são editores de 
vídeo... Isso é cada vez mais real dentro das redações e não dá para a gente sustentar uma banca de jornalista.... “quem é você para sugerir ou quem é você para dizer tal coisa?”... São pessoas que são da área de comunicação, são pessoas que têm o tempo das coisas, que conhecem as coisas, conhecem esses insumos, conhecem esses empacotamentos jornalísticos melhor do que o jornalista.

Entrevistador: Existe alguma dificuldade de diálogo?

E3: Existe. E é natural. Deve existir entre o médico, sei lá, o médico que acha que o problema do paciente é hepatite e o outro diz que não, que é um problema cardíaco e que não tem nada a ver. Existe. E existe de toda ordem, inclusive de resistência de alguns jornalistas em aceitar a "invasão" desses outros profissionais, dessas outras disciplinas dentro do ambiente de redação. Existe, às vezes, por dificuldade de comunicação entre as áreas. A área de programação é muito introspectiva, muito difícil, às vezes, de arrancar algumas coisas, de construir algumas coisas, de construir interfaces mais amigáveis ou de construir soluções interativas que sejam inteligíveis por qualquer pessoa. Enfim, existem dificuldades normais que existem em qualquer ramo interdisciplinar e como o jornalismo é cada vez mais interdisciplinar, a gente tem que gerenciar isso, a gente tem que fazer as coisas andarem.

Entrevistador: Qual a função do editor geral na reunião de pauta?

E3: Eu faço esse papel.... Um pouco de orquestração.... Para garantir o endereçamento da energia para as coisas mais relevantes. Eu faço um papel de intervenção, no sentido de: "Esse assunto não está suficientemente tratado, temos que voltar a esse assunto".... Eu faço um papel de juiz, no sentido de: “Ah, a gente tem duas boas ideias, mas só tem energia para uma, então vamos investir nessa e deu".... Com a caneta que me foi confiada, eu tomo decisões e boa parte delas resultado de construir o consenso e outras que eu tenho que tomar como chefe. Inclusive decisões, às vezes, contra a maioria. Tipo: todo mundo tá achando que o assunto do dia é esse, mas nós vamos nesse, correndo todos os riscos. Como é que eu faço isso? É um pouco de 32 anos de trabalho, mas é bastante de praticar esse jornalismo poroso, vamos dizer assim. Que sabe ouvir as redes sociais, que sabe ouvir as métricas de audiência, que sabe ouvir as demandas diversas que não é só coisa de rato de redação, assim, tomando decisão olhando para o umbigo.

Mas a minha função é essa e aí eu permaneço. Tipo assim: eu e a pauta como fios condutores. Muitas coisas voltam para mim às três da tarde e... "o que a gente faz em relação àquilo?"... Muitas demandas novas... "Surgiu isso e o que é que a gente faz agora?”... Muitas: “ah, não deu certo"... Muitas: “temos que refazer essa matéria”... Muitas: “Complicamos, não era para ser assim e foi assado"... Enfim, é um papel de orquestração da equipe em um 
ambiente bem dinâmico.

Entrevistador: E quem compõe pauta?

E3: Todo mundo. Pauta, pauta vem de todos os lugares e vem da vivência do jornalista, das leituras do jornalista, das conversas que ele trava. Por exemplo, essa discussão de ENEM. O que a gente pensou aqui de ENEM? O que a gente tem que, no digital, empacotar, fazer vários pacotes de matérias de ENEM, várias leituras dos números e soltar ao longo do dia. Nestes empacotamentos do dia, forçar a mão de achar dados, situações, características e peculiaridades do ENEM no Rio Grande do Sul, que é o nosso público, e em uma leitura nacional de ENEM tentar ser original. Muita commoditie de ENEM vai vir pela Agência Estado, pela EBC, e a gente vai publicar. Mas se a gente conseguir ainda ter energia para fazer várias pequenas matérias ao longo do dia, fazer um bom empacotamento para o papel no dia seguinte, fazer uma boa escala de ENEM no Noite e ainda assim no nacional ter uma sacada particular... Legal. Aí a ideia é tentar ver esse negócio da redação. Tentar ver o tal do item cinco da redação, que é direitos humanos e parece que foi flexibilizado porque o tema era mulher e os alunos revelaram-se bastantes conservadores em relação a isso e se fosse levado ao pé da letra o item cinco, o número de zero e desclassificações seria maior. Então, vamos ver se a gente faz essa matéria. Essa matéria pode nos dar uma diferenciação nacional. Mas não sei se vamos conseguir porque o MEC deve ser muito hermético em relação a isso e não vai admitir e porque talvez a nossa perna não nos permita. Então, na construção da pauta, as inferências são várias. Casualmente, essa da redação fui eu quem trouxe porque conversei com um especialista outro dia, que veio aí apresentar um projeto e deu essas dicas. No dia do ENEM, a gente quer valorizar a história do dispositivo anti-chute, que, por circunstâncias, essa mesma pessoa também me deu o nome do professor que criou esse dispositivo. Então, a gente quer conversar com ele, como que é, qual a garantia de que realmente inserindo esse dispositivo no algoritmo do ENEM, da nota, quem chuta não vai se dar bem.

Então é buscando diferenciais, mas poderia ter sido outro. As pessoas sugerem bastante nas reuniões e as pessoas sugerem intensamente ao longo do dia em conversas, em trocas de e-mail, em "vai ali no meio e senta"... ou o cara da editoria lá do outro lado... foi o que a gente falou do menino do (editoria) esporte, que é um noveleiro. Ele não produz, mas sugere. E assim, as redes nos alimentam muito, então pode ser qualquer... Não temos nenhum preconceito. A não ser pautas contaminadas: favorecer alguém ou uma pauta que contenha calúnia, injúria, difamação, essas coisas. Mas não temos preconceito nenhum sobre a origem da pauta, de forma alguma.

Entrevistador: O que seria angulação da pauta ? Qual a importância dessa angulação? 
E3: A angulação tem várias funções. Adaptar a pauta ao nosso público, por exemplo. Tornar a abordagem mais útil para o leitor, tentar dar um olhar original para a pauta. Não para ser original por ser original, mas para ter a commoditie da pauta, mas ter um olhar diferente da pauta. Então, espancar a pauta, um jargão que a gente criou aqui, busca moldar, esculpir a pauta. Isso é necessário para a gente tentar ser mais útil, mais relevante, mais original, mais importante, ganhar mais repercussão seja junto ao grande publico, seja junto aos outros veículos que nos acessam e nos dão créditos. Para isso, a gente tenta não ser tão previsível na abordagem da pauta.

Entrevistador: A pauta restringe o trabalho do repórter?

E3: Pode restringir, para o bem ou para o mal. Pode restringir no sentido de que realmente acertamos a mão na angulação da pauta e o repórter vai explorar o melhor que aquela pauta tem ou se erramos a mão, o repórter pode ir na pista falsa e pode gastar a energia dele. Todos os repórteres têm anticorpos. Eles podem, resultado da vivência, do olhar, do conhecimento, da inteligência deles, contrapor. Dizer: "olha, essa pauta veio azul, mas eu acho que se a gente trabalhá-la pelo lado amarelo, a gente vai se dar melhor". Ou então: "fruto da minha apuração, nas minhas duas primeiras entrevistas, eu percebi que esse viés que a gente tá criando não existe. Que essa pauta é assim e não assado". Então, a pauta restringe, no sentido asséptico da palavra, restringe e pode ser para o bem ou pode ser para o mal.

Agora mesmo, a gente tem um viaduto aqui no centro de Porto Alegre que virou um condomínio de pessoas que moram.... Tem pessoas que passam, inclusive, 24 horas ali porque já nem conseguem sair... Então, tem colchão, geladeira, fogão... Na zona central da cidade... E a pauta que nasceu foi o olhar humano, quem são essas pessoas. Aí, chegou ao repórter e ele devolveu: "Não, as por que a gente não faz a matéria de patrimônio histórico?”. Não, neste caso não. Neste caso, o olhar é humano. É: “Quem são essas pessoas? Por que elas estão lá? O que dá para fazer por elas? O que a presença delas significa para a cidade?". Tá errado fazer o olhar do patrimônio histórico? Não, não tá errado, mas neste momento... "Por quê?".... Porque, coincidentemente, umas dez pessoas da redação mencionaram esse fato porque tem leitores questionando isso, porque teve uma mudança de cenário, que era só um dormitório e virou uma casa, as pessoas passam 24 horas lá.... É para fazer dessa...“Ah, mas quem é que dá esse ... (?)"...Nesse momento fui eu. E isso é uma restrição de pauta.

Entrevistador: As características dos suportes são levadas em consideração na hora de construir a pauta?

E3: Eu te diria assim... Em um grande bloco de matérias não são levadas em consideração na hora de conceber a pauta, mas na hora de empacotar a pauta. Em outro bloco 
de matérias, também considerável, são as características do suporte. Então, por exemplo, ENEM e buscador. Quer dizer, não tem buscador no papel. Não adianta querer apertar botão no papel que não é dinâmico. Tá bem, o buscador é uma grande energia direcionada para fazer o buscador. Tem o repórter que consegue os dados, senta com o programador, eles escolhem o melhor jeito de fazer. O repórter testa e... tudo isso para o digital. E sabemos que o grande uso de buscador é digital web, site. Não é mobile e não é app. Mas enfim, vamos fazer porque é importante.

Então, nesse sentido, em várias situações é determinante o suporte. Mas na origem da pauta, tipo assim ENEM... Bom, nós temos que fazer ENEM. O ENEM é multiplataforma... Como que a gente endereça? Como que a gente empacota? Onde a gente vai colocar mais transpiração para fazer melhor o ENEM nessa plataforma e nessa outra? ... Vamos trabalhar para ter ENEM ao longo do dia no digital e amanhã no papel é só o empacotamento, não precisamos ter nada exclusivo no papel. É só uma edição competente do material. Essa foi a decisão de ENEM. Então, nesse sentido, sim, o suporte é determinante. Na origem que a gente tem que tratar de ENEM, não.

Agora estou pensando aqui, por exemplo, na novela. A novela é mais ou menos a mesma coisa. Quer dizer, esse comentário do primeiro capítulo... Primeiro que o primeiro capítulo terminou dez da noite e a gente avaliou que não precisava ter isso no jornal do dia seguinte. Mas na manhã seguinte, sim. Porque aí tem a jornada do leitor e a gente sabe que os leitores acessam esses tipos de conteúdo, variedades de manhã.

Ok, tá lá o comentário do primeiro capítulo da novela. Vai para o papel amanhã? Provavelmente não. Ou se for para o papel amanhã já é alguma coisa pensando na novela em si e não só no primeiro capítulo. Então, daí o suporte, o tempo, o momento em que o usuário vai acessar aquela informação naquele suporte é determinante para o viés da pauta.

Neste mundo de cultura e entretenimento tem muita coisa que se produz e que não vai para o papel. Então, a Kim Kardashian foi assaltada... Isso é digital. Não vai para o papel. Não queremos que nosso papel seja reconhecido lá fora por um jornal que faz esse tipo de conteúdo. Não por isso ser ruim, mas por uma decisão. Então, aí também o suporte é determinante.

Entrevistador: Você tem falado muito em métricas. Elas são levadas em consideração na produção também do papel? E do tablet?

E3: O tablet, assim conforme eu venho te falando, a gente praticamente não tem uma produção exclusiva para ele. A gente tem uma produção no sentido de empacotamento, que é o Noite e que é o jornal do dia com os seus insumos. A gente tem isto. Então, o tablet não é 
determinante para isso.

Entrevistador: Porque você deve ter públicos específicos para os suportes...

E3: Sim. O papel tem outras referencias. A gente tem um call center que tem um relatório diário de avaliação, que circula em vários editores. A gente tem pesquisas qualitativas e quantitativas ao longo do ano. O papel é muito menos sujeito a métricas do que o digital. Aí tem uma coisa... Se o papel é menos sujeito a métricas que o digital e se no tablet a gente tem dois grandes produtos, o Noite e o Dia, e se esse Dia não é sujeito a métricas, então quem acessa no tablet não vai ler a Kim Kardashian? Aqui não. Ele como assinante pode acessar todo o conteúdo digital e em algum momento vai ver a Kim Kardashian, mas a gente entende que a leitura do tablet, deste produto e do ZH Noite, é mais parecida com esta leitura ((folheando alguma coisa)), do que com essa leitura. Com a leitura de papel.

As pessoas folheiam, as pessoas param para ler, as pessoas têm uma hierarquia. Ela é uma leitura que a gente chama de estruturada. A leitura a partir da home, da capa do site, web ou mobile, ou a partir das redes ou a partir da busca orgânica, é uma leitura desestruturada, infiel, volátil. Enquanto que a leitura aqui, começando pelo fato de que para ler a versão papel no digital ou no ZH Noite, eu tenho que ser assinante. Então, eu tenho um grau de fidelidade à marca muito maior que aquele cara que fica zapeando nas capas de site ou lendo a partir da sua timeline do Facebook.

Primeira coisa: eu tenho que ser assinante, eu tenho que pagar para acessar. Segunda coisa: a dinâmica de leitura se assemelha ao papel. A dinâmica de leitura do ZH Noite e do ZH Dia se assemelha ao papel. Ela é folheada, ela é estruturada visualmente, as coisas são organizadas em um determinado espaço. Não é aquela coisa etérea de uma página HTML, de uma lista de notícias. Tem hierarquia, tem curadoria. Então, a gente acha que ao oferecer para o leitor do tablet, que acessa a versão digital do jornal do dia e do ZH Noite, uma leitura mais adulta, vamos dizer assim, a gente está acertando. Não é o pacote de conteúdo certo para a pessoa errada. É o pacote de conteúdo certo para a pessoa certa.

Então, isso reforça a nossa ideia de que o jornal papel é menos influenciado pelas métricas. Ele é menos influenciado pelos rankings de acesso em redes sociais. Ele é mais influenciado pelo call center todo dia, pelas cartas dos leitores, pelas manifestações que os leitores mandam por meio digital sobre o papel, pelas pesquisas qualitativas e pelas pesquisas quantitativas.

Entrevistador: Pensando nos valores notícias e nessas métricas que tanto se falam, o que teria peso? O que pesa na hora de fazer uma opção por matéria $\mathrm{x}$ em detrimento de outra?

E3: Neste momento eu diria que pesa o coquetel de insights. Não é só um e não é só 
outro. Ninguém aqui é filhote de short bit (?) e de trendings. São ingredientes, são influências que a gente recebe tanto quanto outras. Tanto quanto a imagem da marca Zero Hora. Tanto quanto a própria percepção que o leitor papel, que boa parte do nosso leitor digital é híbrido, então a personalidade que ele expressa nas preferências papel, ele expressa no digital também.

Então, eu acho que as métricas, que o Google Analytics, chat ou short bits (?), trending topics e tudo mais são importantes. Não são decisivos, nem determinantes e nem são as únicas referências. Vou dar um exemplo então: a história da Fernanda Gentil com a jornalista. Em um primeiro momento o Estadão publicou. Ai a Cláudia, que é a editora de cultura e entretenimento, veio e disse: “olha, tem isso"... Tipo: “ué e agora?”... Não, mas relacionamento homossexual não é mais notícia. É bom para a sociedade que não seja mais notícia. Mas ao mesmo quando uma pessoa formadora de opinião, uma pessoa importante assume um relacionamento homossexual e se isso vira notícia, ajuda naturalizar isso. Se isso for tratado com respeito, pelas pessoas e sem sensacionalismo, faz sentido a gente trabalhar esse assunto. A jornalista é gaúcha, sim isso é uma variável. Ela é jornalista, ela tem alguma visibilidade no Rio Grande do Sul. Aqui em Porto Alegre ela é medianamente conhecida. Ela acabou um romance, um relacionamento com outra moça muito conhecida na cidade de Porto Alegre, filha do ex-presidente do Inter. Então você começa a trazer para dentro do coquetel essa serie de ingredientes para tomar a decisão... “Ah, então vamos noticiar”... Mas vamos noticiar com sobriedade. Vamos noticiar a partir da decisão da Fernanda Gentil de anunciar oficialmente isso. "Vamos falar com a Priscila?"... "Não, a Priscila não é tão importante assim. Ela não é tão notícia assim. Não vamos falar com ela"... "Ah, mas a gente tem fotos da Priscila que nenhum outro veículo tem. Vamos usar?”... "Vamos!”... “É foto do crachá funcional dela?”... "Não, não é foto do crachá funcional”... A Priscila atingiu certo nível de “celebridade" na Zero Hora. Ela era uma repórter de esporte reconhecidíssima. Muito boa. Depois ela foi para a área de entretenimento e fez um belo trabalho. Tinha programas em vídeo em uma grade de web que a gente tinha. Então vamos usar a foto dela. Podemos usar a foto dela. Nos sentimos autorizados. Não estamos invadindo... “Que tamanho vai ser?”... "ah, vai ser assim"... “vamos fazer nova apuração?”... "Não, não vamos fazer nova apuração".

A revista Dona, por uma coincidência absurda, abissal, tem uma entrevista marcada às onze horas com a Fernanda Gentil sobre o livro dela. Bom, então tem que perguntar para a Fernanda Gentil sobre isso e ela deu algumas frases que só deu para nós, exclusivas para nós e colocamos na matéria. Então você vai construindo a decisão nesse sentido... "Mas e no papel?"... O papel não tem nenhum suporte que torne possível dar um factual, o repórter anuncia. No papel a gente só noticiou a Daniela Mercury quando ela deu um caráter ativista 
para o relacionamento dela. Quando entrou no contexto do Marco Feliciano. Tem outro contexto. Se a gente, por algum motivo, vier a fazer matéria que tenha como pano de fundo o tema relacionamentos ou como case, elas podem aparecer, mas elas não são notícias no papel.

Então, você vai tomando decisões, vai construindo decisões a partir de um coquetel de insights, entre eles as métricas, que são muito mais relevantes para o digital e muito menos relevantes para o papel.

Entrevistador: O editor e o repórter se comunicam? Existe alguma forma durante o desenvolvimento da pauta?

E3: Total. O tempo inteiro. Permanentemente. Cada situação é uma situação, mas o tempo inteiro se comunicam comigo, se comunicam entre áreas, com editor de fotografia, com o editor de arte. O tempo inteiro. Essa é inclusive uma forte recomendação.

Entrevistador: $\mathrm{O}$ editor tende a alterar a pauta no processo de edição?

E3: Não, no processo de edição não. Não no sentido de inserir na matéria coisas que não são sustentadas pela apuração. Isso não. Isso é errado.

Ele pode alterar no sentido editorialmente, jornalisticamente, como empacotamento. A matéria pode chegar pra ele e ele sentir uma lacuna na apuração, aí ele volta para o repórter e pede para o repórter reapurar alguma coisa. Se o repórter não estiver ali, ele vai na equipe dele e tenta achar alguém que pode resolver. Ele pode diante de uma matéria que ele acha que não está completa a apuração mediante uma negociação que pode me envolver ou não, pode envolver o editor de área, segurar a matéria para publicar depois. Mil coisas. Ele tem uma grande autonomia, menos para manipular, menos para fazer um titulo que não tem nada a ver com o conteúdo. 
Apêndice N - Produtor 1 do Zero Hora

Entrevistador: Qual a função da pauta no jornal?

Produtor: Acho que ela tem uma função fundamental. É na pauta que agente consegue identificar os veículos. Se eu for muito prezo ao factual, sem apresentar nenhum diferencial, perco ponto aí. Eu acho que ela é o roteiro das próprias matérias. Ela tem o papel de dá o tom, e a gente não pode ficar só contando o que aconteceu, a gente precisa que a matéria seja interpretativa e analítica.

Entrevistador: É possível dizer que existi mais que um tipo de pauta?

Produtor: Eu nunca trabalhei em outro sistema de pauta. Sempre trabalhei nessa sistemática, de não só cobrir o assunto, mas também tentar orientar o repórter. Ela seja talvez a principal estância na hora da produção da reportagem, por exemplo: quando um repórter sai para a pauta e descobri que algo totalmente diferente do que foi imaginado.

Produtor: Existe um respeito muito grande pelo que o repórter apurou. Pra mim, a estância que mais muda matéria, é o momento da apuração. São momentos que você vai melhorando a pauta. Eu acho que isso é muito bom. Ela tem três estâncias: quando ela é formada na cabeça do editor, depois a conversa do produtor com o repórter e tem no mínimo mais dois momentos de remodelagem.

Entrevistador: Você acha que a reunião é uma estância de aprimoramento da pauta?

Produtor: Eu vejo a reunião como fundamental. Vêm pessoas que não acompanham o dia-dia da editoria, e vai te dar essa visão mais distante do assunto. O que é extremamente positiva. Ela pode te trazer visões não tão perceptivas. Esse é objetivo maior, e algumas vezes garantir uma uniformidade ao jornal, e fazer com que todos os compromissos sejam mantidos.

Entrevistador: O que você acha que seja levado em consideração para que uma pauta seja aprovada?

Produtor: A primeira é o interesse publico ou interesse do publico. Mas a gente acha mais importante é oferecer o que é de interesse do leitor. A segunda coisa é a originalidade, é difícil ser original fazendo um produto como site, mas muitas vezes estar em tentar achar um ângulo diferente do mesmo assunto. As fezes estão em uma fonte diferente. Um dos nossos grandes desafios é encontrar uma maneira de ser diferente, a questão ética, e também a questão da audiência é levado em conta.

Entrevistador: A linha editoria é levada em consideração?

Produtor: Sim. Não tem como escapar, em qualquer veiculo. A nossa linha, inclusive, está passando por um novo processo. Um processo de reposicionamento. O jornal aborda uma 
demanda grande de assuntos nacionais, mas têm como foco os regionais, isso que nos diferencia do: Estadão, UOL e demais veículos. Então essa é a premisse que está pro trás de nossa linha editorial.

Entrevistador: Quem aprova a pauta?

Produtor:Em Primeira estância é o editor chefe. Ele que acaba assumido, aqui na Zero Hora, essa função.

Entrevistador: Pauta restringe o trabalho do repórter?

Produtor:Eu acho que ela ajuda dá um foco. Ela é maneira que nós encontramos para que se torne possível produzir uma reportagem. Uma noticia. Mas no processo que temos hoje, eu acho difícil uma reportagem sem uma pauta. A pauta é necessária porque ela dá certa objetividade para a produção do conteúdo. Salvo em caso especiais, como matérias especiais onde o repórter vai passar uma ou duas semanas recolhendo informação e depois vais direcionar todo esse conteúdo para um determinado ponto.

Entrevistador: Quais critérios são utilizados para separar que um conteúdo vá para o impresso ou para o online?

Produtor: Hoje nossa produção está voltada muito para o online. É um processo que levou um certo tempo. Mas a principio a gente acaba fazendo a publicação de conteúdos pensando no online. Por exemplo, a maior denuncia que fizemos esse ano, sobre problema de gestão dos portos fluviais aqui de Porto Alegre. A gente decidiu que teria uma maior repercussão se fosse publicada no inicio da manhã no site. E isso era impensável á uns anos atrás. A gente tem orientação quanto a isso.

Produtor: As pessoas publicam o conteúdo no online e depois pensa em como passar isso para o papel. Até porque a produção do papel tem o compromisso de apresentar uma explicação mais detalhado do conteúdo do dia anterior. Ou antecipar as coisas do dia seguintes. Ele pode dar essa hierarquizada de assuntos que ainda não encontramos a maneira de fazer no online. Além de uma analise do que aconteceu ao longo do dia. Apesar do online já conseguir dá esse suporte.

Produtor: Outras vezes tem pautas que tem mais cara de online. Ou se faz uma grande discussão sobre o tema.

Entrevistador: Para determinar esse valor, você analisam as características do suporte?

Produtor: Sim. Muitas vezes o vídeo tem uma marcar muito importe para o online, e no papel não tem como valorizar isso. Porque a historia está mais bem contada no vídeo. Então, sim. O suporte influência bastante nessa decisão.

Repórter- Quais elementos uma pauta deve conter? 
Produtor: Aqui a gente considera mais importante é as duvidas. Mas do quê a certeza "do que é isso ou aquilo". As questões que os repórteres precisam ir atrás. O papel do pauteiro e passar para o repórter as perguntas que precisam ser respondidas. Eu não gosto de matéria que direciona a pauta. É preciso ter cuidado para não induzir o repórter ir atrás da resposta.

Entrevistador: O que seria a angulação da pauta?

Produtor: Uma porque a gente não teria condições de fazer tudo sobre um determinado assunto. Fazer um " $360^{\circ}$ " de um tema, algumas fazes acontece, mas não dá pra ser sempre assim. Seria buscar um lado do assunto que não foi muito trabalhado.

Entrevistador: De onde surgia as pautas?

Produtor: Vários lugares: Cabeça dos pauteiros, da cabeça dos repórteres, algumas vezes de assessor de imprensa, percepções das pessoas. Qualquer lugar é fonte de pauta.

Entrevistador: As métricas são utilizadas para construção da pauta?

Produtor: Em alguns momentos, sim. Ela serve para chamar a atenção assuntos que estão sendo discutidos mais que não apresentamos ainda. Eu acho que essas ferramentas contribuíram para nós dar uma visão geral das coisas. Contribuíram para percebemos o que é importante para o leitor. Porém tem que ter cuidado para isso não se tornar o único instrumento de avaliação. Tu só dar o que está tendo audiência, isso não é legal.

Entrevistador: Com a digitalização do jornalismo, surgiram novos atores no processo de produção. As chegadas desses novos profissionais tencionaram de alguma forma o processo de produção?

Produtor: Derrubar uma pauta, é mais difícil, porém, ela facilmente pode alterar a forma que o assunto vai ser passado e o tempo que ele vai produzido. Por conta dos dispositivos que estão sendo incluído, às vezes é necessário um tempo maior de produção. Mesma coisa com os gráficos e banco de dados. Também Interfere na abordagem e na apuração.

Entrevistador: Existe uma tensão nesse processo?

Produtor: Eu acho que normalmente, não. Não vejo muitos problemas, aqui nós temos uma equipe que entende a forma que a coisa tem que ser produzida.

Entrevistador: $O$ fato de está dentro de uma redação convergente, trás alguma diferença?

Produtor: Eu acredito que no fim das contas, nos acabamos melhorando o produto. Contamos com novos recursos para contar uma historia. Cobrimos menos assuntos, mas quando cobrimos, é de uma melhor forma. Eu acho que reduziu um pouco a obrigação de se ter todas as informações, hoje, temos que ter as mais importantes. 
Nos disponibilizamos a contar a historia da melhor maneira possível. E essa foi uma mudança grande. Temos uma consciência que não é possível cobrir tudo, mas tu vai avaliar se vala ou não publicar isso. 
Apêndice $\mathrm{O}$ - Produtor 2 do Zero Hora

Entrevistador: Qual a função da pauta no jornal?

Produtor 2: Pra nós, a pauta é o eixo central no qual se organiza toda produção do jornal. Ela começa a ser formatada na véspera, isso na pauta que será executada no dia seguinte, ela começa a ser planejada na véspera com as principais apostas que nós temos para o dia seguinte. Para não ocorrer de o jornal não ter a mínima ideia do que poderá ser noticia ou manchete. Ás apostas de foto de capa, por exemplo, para o site ou impresso. Então ideia é que a gente já entregue isso no final da noite ou no início da manhã. Em função disso, vai sendo construído toda produção do jornal. Os esforços para garantir àquela manchete, as fotos de capa, as outras matérias que vão rendendo manchetes ao logo do dia no site; então ela (pauta) é o eixo central porque em função dela que os esforços de repórteres, fotógrafos, editores e os profissionais de vídeos e imagens vão trabalhando.

A Zero Hora trabalha atualmente, no esquema de tentar se organizar ao máximo, porém, tendo espaço para fazer as alterações. Então as pautas que nós executamos diariamente aqui, as linhas gerais dela, pelo menos os principais assuntos, já tentam ser pensados na semana anterior. Par nós termos uma aposta diária de assuntos. Que possa ser o principal assunto do dia.

Entrevistador: Existe alguma hierarquia desses conteúdos? Quando você lista os assuntos. E como é feito?

Produtor 2: Cada dia nós temos que ter o que chamamos de aposto dia, que na verdade é a reportagem especial, que no caso do impresso, abre o jornal. Que geralmente, no caso de conteúdos que não são factuais, que são elaborados com mais tempo, mais antecedência. São agendados no site para entrar já na madrugada nas primeiras horas do dia. Esses ocorrem quando a reportagem especial é um fato eminente do dia, por exemplo: o resultado das eleições, o atentado terrorista, o grande acidente que possa acontecer no dia; aí essa matéria vai entrando fracionada ao logo do dia no site. O que é apresentado ao logo do dia, na verdade é um copilado de varias matéria feitas ao logo do dia para o site. Mas normalmente acontece ao contrario. A gente já tem um repórter trabalhando um ou dois dias naquele assunto, e aí ele é agendado para madrugada.

Entrevistador: Qual seria a função da reunião de pauta?

Produtor 2: A reunião de pauta aqui é dividida em três. A da manhã é a principal do jornal. Porque ali se tenta hierarquizar melhor os assuntos para montar o corpo do jornal e do site daquele dia. Esses levam as pré-pautas da noite já encorpadas com alguma coisa que 
aconteceu pela manhã, e delas se define os rumos do jornal. Cada editoria leva a sua e é montada a pauta conjunta do jornal. Às vezes a ideia que nós tivemos aqui na editoria, pode ser alterada pelo editor chefe- esse assunto não rede muito, ou estamos com assuntos muito densos, vamos dar uma diversificada ou não temos nenhuma foto boa, temos poucos vídeos previstos para o dia- e aí tem uma reunião as $17 \mathrm{~h}$ que é um pouco mais focada no impresso, para definir o que vais ser manchete ou que se aposto de manhã que está rendendo ou não, o que se tem mais de interessante para ir para capa do jornal, ou que está acontecendo que poderia entrar no site agora a noite.

E antes disso, tem uma reunião que cada editoria costuma fazer uma vez por semana, que além de conversar sobre coisas de ordem mais operacional de cada equipe, pede sugestões dos repórteres para discutir o que pode ser feito quais assuntos nos poderíamos abordar.

Entrevistador: Na sua visão, o que é levado para uma aprovação de uma pauta?

Produtor 2: Depende o que se espera daquela pauta. Se é uma sugestão de pauta para ser manchete do jornal, nós temos que ver exatamente se ela tem estufo para isso. O que ela rende de chamada, quais os dados que ela vai trazer, o que ela traz de novo, o que evoluiu em relação ao que já foi feito sobre o mesmo assunto, qual o tamanho que ela vi ter. E tem outras pautas que menos despretensiosas, são boas porque realmente rende uma foto legal, um vídeo bacana, ou um foque mais diferenciado sobre algum assunto. Às vezes uma pauta bem interessante pode ser um assunto em pequeno, por exemplo: Um colega nosso resolveu fazer um matéria sobre dinheiro arrecadado com multa de transito aqui em Porto Alegre, que estava sendo usado para equipar hospitais e escola. É uma pauta que jamais seria manchete, porém, ela é legal porque mostra um lado diferente dais coisas. E quando a pauta tem ambição maior, como a do final de semana que tem que ter um tamanho maior, aí realmente tem que ser assunto que se imponha e justifique o investimento maior de tempo e dinheiro.

Entrevistador: Você acredita que uma pauta restringe o trabalho do repórter?

Produtor 2: Não. Agora o repórter não pode ser escravo da pauta. Ele tem que trazer o mínimo que a pauta pede por ela ser um ponto de partida do trabalho dele. Quando o repórter é mais inexperiente, ou não tem tanta afinidade com aquele tipo de assunto, a pauta é um eixo para ele seguir respondendo aqueles pedidos mínimos. Daí ele vai ter uma matéria que se sustenta. Porém quando o repórter é mais experiente, tem mais intimidade com aquele assunto, só pega aquilo como ponto de partida e acaba desenvolvendo bem mais ou vai chegar local e ver que o assunto mais quente é outro. O repórter tem a liberdade para fazer isso, só que ele tem justificar pelo material apresentado porque ele inverteu, mudou ou derrubou o 
assunto pré determinado.

Entrevistador: Quando você faz uma pauta leva em consideração as características do suporte? Existe alguma preocupação em relação

Produtor 2: Sim. Tem algumas pautas que a gente diz: não, é só um online mesmo. Porque aí pode sustentar só o vídeo, só na imagem o um quiz para ir pro site, no impresso, principalmente pela característica de enxugamento cada vez maiores dos jornais. O que se faz é um enxugamento dos assuntos. A produção online é muito maior que o impresso. Alguns assuntos são mais para online do quê para o impresso. Nós já sabemos que vão ser ruins de audiência no site, mas vão ser importantes pela relevância, então, vamos ter que abrir uma pagina, mesmo sabendo que a audiência dela vais ser "pif". Pautas por exemplo que a gente sabe que vai render algumas linhas, mas pro site vai ter uma visibilidade maior ou pelo tema ou pelo disponibilidade de vídeo, infográfico ou quis.

Entrevistador: Esse tipo de preocupação existe para o ZH noite?

Produtor 2: Esse tipo de insumo é mais discutido na reunião da 10h. Mais a questão é não usar alguns insumos que nos vamos usar na edição do impresso, por exemplo: Não usar a mesma foto que utilizada no site ao longo dia. A ideia é tentar entregar alguma coisa diferenciada.

Entrevistador: Quais são os elementos que a pauta tem que conter?

Produtor 2: Depende, se ela for uma reportagem especial de uma editoria, por exemplo: a pauta de amanhã é sobre as nova composição da câmara de vereadores aqui de Porto Alegre. Então além de ter um texto explicativo, é necessário um infográfico que ajude a analisar essa informação.

Entrevistador: É papel do pauteiro solicitar isso?

Produtor 2: Sim. Ele já tem que colocar na pauta aquilo que ele vai querer que o repórter consiga então na hora de conceber a pauta você já pede. A gente tenta detalhar o máximo para repórter. Isso não dispensa um conversa pessoal. A gente pede para que o repórter converse com o pauteiro é sempre bom complementar verbalmente. Par que ele saiba o que tem que pedir das fontes que ele vai entrevistar.

Entrevistador: Existe a possibilidade de uma pauta cair?

Sim. Ou porque pauta não se sustenta, as vezes a gente tem uma ideia aqui, mas na vida real ela não é assim. Às vezes elas reduzem de tamanho, reduz a abrangência, rara vezes elas caem por completo, algumas vezes por falta de repórter ou fotografo. Eles podem estar em alguma pauta, é preciso deloca-los para uma outra mais relevante.Ou o perfil ideal para tocar essa pauta é fulano que hoje não pode, está envolvido em outro assunto ou está em 
viagem. Mas normalmente quando as pautas caem, é porque tem que adequar ao numero de pessoas.

Entrevistador: O que seria a "angulação" de uma pauta ou enfoque?

Produtor 2: Seria a maneira que você vai abordar determinado assunto. A gente sempre tenta dá a angulação ou enfoque do ponto e vista do leitor- O que me interessa saber sobre esse assunto?- eu não estou escrevendo essa pauta para fonte nem para os meus colegas jornalistas. Sempre pensando no interesse comum do leitor. Muitas vezes alguma entidade faz alguma divulgação de dados. Você manda o repórter lá, mas na verdade usa aquilo para fazer outra discussão sobre aquele mesmo assunto. A questão é sempre tentar trazer a angulação da pauta para tentar contemplar o interesse do leitor e o mais amplo possível.

Entrevistador: De onde surgem as pautas?

Produtor 2: Existem basicamente quatro maneiras. Uma é o clássico: O relise; Outras é que a partir do relise você tem uma ideia diferente; pode surgir de leitores que ligam ou mandam email. Algumas são assuntos pessoais, mas às vezes pode ser um assunto comum a muitas outras pessoas, repórteres sugerem, porém, tem que ter um equilíbrio do que é sugerido; outra forma é quando você acompanha o que os outros veículos estão dando, não é a mais nobre, porém é uma forma.

Entrevistador: Você acredita que o background do pauteito tem alguma influencia sob o que é proposto?

Produtor 2: Eu acho que sim. Quanto maior for o conhecimento da pessoa sobre o assunto, maior será seu embasamento sobre aquele tema- Pela experiência que eu tenho sobre esses números eu sei que esse está totalmente fora da curva, nos últimos vintes anos que eu cubro esse assunto nunca vi nada dessa maneira- De certa forma ajuda estruturar bem melhor a pauta. O background do pauteiro também é bom para filtrar melhor as informações. Dizer qual terá melhor repercussão ou não.

Entrevistador: As métricas têm influenciado de alguma forma as pautas de vocês?

Produtor 2: Sim. Assuntos que a gente sabe que tem mais interesse, tem mais leitura a gente tenta fazer uma força para que ele se imponha na pauta e seja feito. Talvez á uns anos atrás não se fizesse esse movimento.

Entrevistador: O contato com outros profissionais da área do jornalismo, no caso: os programadores, designers, e outros. Tem influenciado de alguma forma esse processo de criação de pauta?

Produtor 2: As vezes você tem ideias, mas se você não tiver um profissional disponível para aquilo, não adianta. Às vezes o diretor de arte fala que vai ter que ocupar um 
profissional durante uma semana para fazer aquilo que vocês está pensando. Daí não é viável, ou você tem uma ideia e o programador ou designer diz que isso aqui não vai funcionar como você está pensando.

Muitas vezes a gente tem repensar ou filtrar alguns assuntos para usar menos dados ou apresenta-los de forma diferente.

Essa equipe poderia derrubar uma pauta?

Poderia. Se a pauta se sustenta só com o infográfico e não tem como ele ser feito, derruba. Ou uma pauta que se baseia em uma imagem ou vídeo e não tem como ela ser produzida pelo profissional de imagem, ela acaba sendo derrubada.

Entrevistador: Existe alguma tensão com esses profissionais?

Produtor 2: Já houve mais, principalmente com o pessoal de foto mais antigo. Às vezes era complicado você explicar pro sujeito que a melhor foto não era um flagrante, mais sim, uma imagem melhor produzida. Mais nos últimos anos melhorou bastante. O pessoal da arte e da programação é mais aberto.

Entrevistador: Vocês costumam sugerir pautas por gêneros? Noticia, reportagem ou perfil.

Produtor 2: Sim. Opinativo, não. Porque é editoria de noticias, e tem a editoria de opinião pronta para isso e ela tem uma dinâmica diferente. Mas por exemplo, uma cobertura eleitoral, nos trabalhamos com diferentes gêneros. A entrevista com os candidatos, perfis dos candidatos, gravação de vídeos...

Entrevistador: Isso é solicitado pelos pauteiros?

Produtor 2: Sim.

Entrevistador: O desenvolvimento da pauta é acompanhado de alguma forma pelos pauteiros?

Produtor 2: Sim. Quando a gente passa a pauta, nós vamos acompanhando o repórter para ver está rendendo ou não. A administração da pauta é feita por nós também.

Entrevistador: Porque meio? Telefone

Produtor 2: Entrevistado: Quando ele está rua, por telefone. Ou por email. Quando está aqui na redação, é verbalmente mesmo. Principalmente as pautas que a gente sabe que são mais trabalhosas.

Entrevistador: O fato de você está dentro de um redação que produz para diferentes suportes, traz alguma implicação?

Produtor 2: Entrevistado: Alterou porque, hoje é impossível pensar na produção da noticia sem pensar nas plataformas digitas. Por exemplo: quando eu entrei aqui já existia o 
site da ZR mais praticamente ele só reproduzia o conteúdo do jornal. Agora inverteu primeiro pensamos no site pra depois pensar o impresso. Não perdeu a importância de se pensar em uma manchete e na foto de capa, mas o maior volume é pensado para o site. O impresso fica com empacotamento daquilo que foi pensado para o site. 
Apêndice P - Repórter 1 do Zero Hora Noite

Entrevistador: Qual a função repórter do ZH noite?

Repórter 1: O repórter do jornal não chega até muita função, porque o conteúdo é construído com material de agência. Talvez no esporte tenha mais protagonismo, mais no geral, os repórteres estão um pouco afastados por não haver muita relação com o conteúdo. Às vezes é uma matéria que tem um desdobramento e o repórter não vem nós avisar. Por esse formato, acaba não interagindo muito com a plataforma, talvez alguns que passou por um processo de aculturamento e aprendeu a lidar com essa plataforma nós ofereçam um melhor suporte. Mas muitas vezes o repórter toma furo porque não vêm nos avisar possíveis desdobramentos da matéria.

Entrevistador: Qual a sua função com repórter?

Repórter 1: A minha função é observa possíveis informações que possam estar incorretas, as vezes levantar um telefone para falar com delegado, apurar alguma coisa, o esforço é mais como edição do quê propriamente com repórter.

Entrevistador: Quais são a competências que você considera importantes para atuar no ZH Noite?

Entender o fluxo de produção, entender de edição, manjar de designer, conhecer o projeto gráfico do jornal e compreender de decodificação para poder resolver algum problema que possa dar no servidor ; saber hierarquizar as coisas e ser bem ágio.

Entrevistador: Existe alguma orientação para produzir matérias multimídias?

Repórter 1: Já houve, as coisas eram pensadas para o online com conteúdos sempre multimídia, tentar agregar o maior numero de insumos a esses conteúdos. Pensar em coisas que fossem exclusivas. Mas agora, como o processo de comunicação entre a gente e os editores é falho, eu não sei se essa orientação persiste. Pelo o conteúdo que recebo, não persiste, não.

Entrevistador: Quando você escolhe um formato para determinada coisa há uma indicação de qual formato é melhor que o outro?

Repórter 1: Por termos de navegação, tem coisa que tu caba priorizando. Tu pode colocar um vídeo que ele vai abrir direto no aplicativo do jornal, mas se tu for disponibilizar um áudio, provavelmente você vai usar um aplicativo. Na verdade é mais relacionado a usabilidade desse usuário que vai utilizar no tablet, do que alguma hierarquização de mídia ou formato.

Entrevistador:Por ser um dispositivo móvel, existe alguma diferença em editar 
conteúdo?

Repórter 1: Sim. Você tem que pensar não só em fazer uma pagina mais leve, como a proposta dele é ser um resumo dos acontecimentos do dia, você acaba picotando um pouco mais. Foi um habito que eu acabei adquirindo. Não de forma que o leitor se disperse, mas que se informe de maneira suscita. A ideia é de certa forma, fazer com que caiba mais coisas. Não cabe? Manda para o site.

Entrevistador: Existe alguma preocupação com a interatividade? Com o conteúdo

Repórter 1: Durante o lançamento houve um pesquisa que tu respondia o que tava achando da tua experiência. Nos chegamos a uma conclusão em junho, mas na verdade, depois que voltaram esses resultados não tem mas essa preocupação com a interatividade.

Entrevistador: Existe algum tamanho aconselhável para construção de texto?

Repórter 1: Quando eu vou orientar- pensa que o abre vai ter trinta centímetros- o resto a gente corta. Fora isso, não é uma coisa que agente se preocupe muito.

Entrevistador: O fato do Zero Hora da ter vários suportes em sua redação pesa alguma implicação no processo de construção?

Repórter 1: O que eu acho que tu está em um meio multiplataforma ajuda, porque todo mundo sabe de tudo. Se a pessoa do seu lado não sabe, ela vai saber te apontar quem sabe. Isso torna a edição mais ágil. Mas ao mesmo tempo, tem a preocupação de não repetir o mesmo papel. A sua matéria é assunto do dia, mas você tem que dar uma roupagem diferente para não repetir nenhuma frase que já saiu no papel. Isso é a única coisa que eu acho emperra. Mas a presença dos editores para sugerir vídeo ou galeria acrescenta sim.

Entrevistador: Isso acaba causando algum impacto no processo de seleção?

Repórter 1: Com certeza. Nesse sentido eu acho que tem um aporte legal. 
Apêndice Q - Editor 1 do Zero Hora Noite

Entrevistador: Qual a função do editor no ZH noite?

Editor 1 Zero Hora Noite: É basicamente, os conteúdos das mais diversas editorias são produzidos durante o dia, e a gente (do $\mathrm{ZH}$ noite) reaproveita esse material, tanto dentro do News quanto o do próprio site, porque é nossa função é condensa esse material e montar um resumo do dia para que fique claro na cabeça do leitor o que aconteceu durante todo o dia. A gente pega essas matérias e transforma em um conteúdo leve para o leitor que vai baixar no aplicativo com a edição do dia com os fato que acorreram nesse dia.

Entrevistador: Quais as competências que você acha necessárias para atuar no ZH Noite?

Editor 1 Zero Hora Noite: Eu não acho que há uma competência especifica para atuar no $\mathrm{ZH}$ noite. $\mathrm{O}$ que eu acho que faça a diferença é uma demanda de certa experiência com outras editorias. Eu já trabalhei em diversas editorias, atuei no esporte, na geral e "Em Sua Vida”. Temos (ele e a Fernanda) uma vivencia bacana em relação a outros colegas no sentido ter experiência em outras editorias. Além da agilidade e pensamento rápido na hora de ver o que melhor para abrir o caderno. E acredito que uma experiência com no digital conta também. Já que o ZH Noite é uma mistura dos dois. Ele é um produto digital com ares de impresso. Isso ajuda na hora de pensar na remição, pensar no vídeo. Tem que ficar ligado.

Mas é normal. Tem gente que vem no domingo no "Domingo Digital" que é o ZH Noite do final de semana. Que é um resumo do sábado e do domingo de manhã. Um pouco mais sofisticado com colunistas, palavras-cruzadas, sudoku... Que vão sendo pensados pelas editorias durante a semana, já que nos outros dias não teríamos condições de elabora esse material para ir ao ar.

Repórter-Quais ferramentas vocês utilizam para produção do ZH noite?

EZHN: Nos utilizamos o News que é ferramenta de escrita daqui do ZH; o Nica que é ferramenta de foto; o indesing e nós temos a Marvin que é o local onde a gente sobe as paginas e coloca os links. Tirando isso, a internet e o Outlook.

Entrevistador: Quando acontece um fato extraordinário e vocês precisam cobrir ou fazer alguma coisa. Vocês utilizam alguma ferramenta de apuração? Como é feito esse processo?

EZHN: A gente ( eu e a Fernanda) apura muito pouco. A gente mais questiona as editorias. E como nós somos editores a gente esse material geralmente já encaminhado e revisado, tanto na questão ortográfica quanto pelos editores diários. Que são pessoas 
competentes dentro das editorias. Mas às vezes acontece alguma coisa e nós vamos questionar. Por exemplo, se acontece a morte do Eduardo Campos ás 17h, sendo que o jornal fecha às $19 \mathrm{~h}$, dá pra nós nos dividimos, um fica com o resto e o outro pega a pagina. Mas se acontece às $18 \mathrm{~h}$, aí acontece uma coisa interessante. Nós temos uma ferramenta chamada "Di Ultima Hora" é uma parte colocada na capa em baixo, com uma frase em amarelo que vai o que aconteceu de na ultima hora e que precisa ir pro ar.

Entrevistador:Vocês produziram esse conteúdo ou esse conteúdo viria empacotado?

EZHN: Nos esperaríamos o conteúdo vim empacotado, porém, se a gente acha que vale á pena mudar, como um coisa extraordinária, como a morte de Eduardo Campos, nós colocaríamos uma foto um abre ou até mesmo um conteúdo de agencia. A gente tem esse recurso (Di ultima hora) para quando acontecer algo desse tipo.

Entrevistador: As métricas têm influenciado de alguma forma a produção de conteúdo?

EZHN: A gente não pensa diretamente, mas sim, em fazer o conteúdo do dia. Eu acho que vai ser uma coisa que vai influenciar cada vez mais, mas por agora, não influencia tanto. Pelo menos não no ZH Noite. O que a gente tem mesmo é a ideia do que é noticia ou o que não é .para servir como o factual

Entrevistador: Existi alguma orientação para produzir conteúdos midiáticos? Como áudio, vídeos e formatos diferentes.

EZHN: Eu acho que isso já está tão incorporado aqui na redação, que às vezes eu chego nos editores e falo: gente, nós vamos ter um vídeo ou a galeria desse assunto? Algumas vezes rola os dois, outras, só o vídeo ou só a galeria. Acontece de alguns dias não ter fotos legais para se ter uma galeria e nós acabamos pedindo para a foto fazer. As coisas aqui já se organizam para acontecer dessa forma, para ter um conteúdo digital.

Entrevistador: Na hora de escolher um conteúdo midiático você utiliza algum critério? O define o melhor momento pra utilizar um vídeo um texto?

EZHN: Não tem um tipo de conteúdo melhor. O que acontece é que as vezes a gente vai pensando a pagina com que a gente tem. E a gente já prever-Opa, isso vai acontece agora á tarde- então nós temos que pensar no espaço. Vai ter vídeo? Não vai ter vídeo? Vai ter foto, mas não vai ter galeria. Não existe uma receita pronta.

Entrevistador: Por se tratar de um dispositivo móvel, é diferente ditar um texto?

EZHN: Não. A gente sempre tenta deixar o texto o mais leve e compacto possível. Mais direto e mais objetivo. Procura tirar algum adjetivo ou advérbio, deixa só o tradicional essas coisas para deixar o texto mais "jogo rápido" só pro cara pegar, e ler e se formar de 
alguma maneira. Talvez possamos ser até criticado, por não ser uma mídia analítica. Mais é a nossa proposta; apresentar o factual do dia sem qualquer discussão.

Entrevistador: Na produção de conteúdo, é utilizado de alguma maneira um material que já foi produzido?

EZHN: Pode sim. Dependendo até por necessidade a gente faz isso. Até pra deixar a pagina mais leve. Não pode ser uma coisa desatualizada, mas se for algo que possa sustentar a meteria complementando com algum numera ou dado. Não há problema em reaproveitar um material passado. Pode e deve ser algo que acrescente sempre ao leitor.

Entrevistador: Há alguma preocupação quanto a interatividade do usuário com o conteúdo?

EZHN: A ideia é sempre ter o maximo de mídias digitais possíveis. O texto, a foto, vídeo e a galeria. Perfeito. Tudo isso mesclado, é a matéria perfeita. Nem sempre a gente consegui. Mas a ideia é sempre apresentar esse tipo de conteúdo aos nossos leitores

Entrevistador: Há um trabalho aconselhável quanto ao tamanho do texto?

EZHN: Não um há padrão, a gente que tem que fazer o serviço de colocar em ordem o texto.

Entrevistador: Existe alguma orientação para a quantidade de texto que serão produzidos no dia? Existe o numero de paginas definido?

EZHN: O numero de paginas é sempre igual. Sempre nove paginas de conteúdos e uma de anuncio. Então esse material as editorias sabem que tem encaminhar para nós, para montarmos a paginas e desenhar elas com os diagramadores. Mas às vezes quando um assunto é extraordinário, como foi o caso do impeachment da presidente Dilma, separamos duas paginas para aquele tema. A gente tem essa possibilidade.

Entrevistador: O fato do Zero Hora ter vario suportes em sua redação implica de alguma forma no processo de produção de vocês?

Repórter 2: Não. Acho que ajuda no sentido de tu ter duvidas as vezes e poder falar tanto com o pessoal do online quanto o do impresso. Com os chefes do meio, eu acho que só acrescenta na verdade. 
Apêndice R - Programador do Zero Hora

Entrevistador: É possível afirmar nesse cenário, que a redação funciona em torno dos jornalistas?

Programador do Zero Hora: Até certo ponto, sim. Mas tem sempre um lugar que você consegue fazer sugestões, consegue levantar uma pauta. Você consegue mostrar possibilidades novas que eles não atentam. E às vezes até a própria pauta em se, está escondida. Dados que não estão visível á olho nu, como um numero de umas estáticas. Às vezes tu pode descobrir uma noticia que passou em branco por não ser um material muito fácil. Não precisa mais só do "feeling” as vezes você pode processar essa massa de conteúdos que tem em domínio publico, e dar uma temática nova.

Entrevistador: Até que ponto a sua função pode interferir na produção de conteúdo? Vocês acham que podem, por exemplo: derrubar uma pauta?

PZH: O que pode acontecer que é o caso aqui do Zero Hora, nós temos um espaço no site que é para edições especiais. São historias contadas de um jeito mais extenso. E pode acorrer é de ser que demanda que leve muito tempo e mais técnica. Acontece discussões, como nós temos um background mais forte, quando algumas estáticas pra nós não parece um desvio muito grande. Ainda não temos uma maturidade para derrubar pauta mesmo com esse domínio. Acontece.

Entrevistador: Designer e programadores partilham do mesmo conceito de noticia?

PZH: Não. Tem divergências principalmente da faixa de idade. E o jeito de encarar as coisas. Os programadores que temos aqui veem a noticia de um jeito mais matemático um pouco mais frio. Então isso acaba dando uma interpretação diferente da noticia.

Entrevistador: E você acredita que isso gere alguma tensão?

PZH: As vezes, mas nada muito grande. Que leve a pensar se vale mesmo a pena discutir o assunto.

Entrevistador: Você acredita que há espaço nas redações para profissionais híbridos?

PZH:É algo em interessante. E tem espaço sim. Não só no conteúdo, mais a forma que é apresentado. Eu acho que é levado mais em conta as noções dos designers do quê da programação. Porque se tu conseguir apresentar ele (conteúdo) com uma forma boa, já leva vantagem. Porque o conteúdo, devido ao mediatismo, é mais complicado de conseguir de uma forma boa. Então você apresentado ele com uma forma melhor, já é vantagem. 
Apêndice S - Editor-Geral Diário do Nordeste

Entrevistador: Qual a função do editor no Diário do Nordeste?

A minha função é acompanhar todo fluxo de noticia. E participar da elaboração, discussão e edição. O seja, eu sou responsável pelo conteúdo editorial do jornal. Devida a gama de informações que temos hoje, o nosso objetivo é filtrar esse volume de informação.

Entrevistador: A edição do conteúdo altera a pauta?

Altera. A pauta é o começo de tudo e isso cabe a redação promover uma discussão do que se deve fazer. Para que quando o repórter vá para apuração, ela já tenha em mente o que se deve fazer.

Entrevistador: Qual a função da reunião de pauta?

A reunião é importante porque é nela que as pautas serão discutidas e melhor elaboradas. Ela precisa de certo modo ser avaliada entre as áreas. O que vai ser extramente positivo para o trabalho final. Porque ali você vai fazer uma discussão com uma visão de fora da editoria. A reunião é grande momento onde você pode discutir cada pauta.

Entrevistador: A integração da redação alterou de certa forma o processo de produção?

Drasticamente. Porque nós viemos de uma geração onde a internet era uma coisa e redação era outra. Então quem trabalhava em uma redação de jornal, presenciou uma transformação em seu ambiente de trabalho. Antes nós pensávamos primeiro no impresso e depois na internet. Alterou toda a nossa lógica de trabalho. E não tem como ser de outra forma, a internet é assim. Mais rápida mais "hardnews". Os leitores de internet estão sempre atrás de conteúdo da maneira mais rápida possível sempre. Chamamos de geração "F5". E o jornal tem uma credibilidade muito forte, e isso foi levado para internet. É uma maneira de trabalhar que está mudando muito a característica de se fazer jornal. Uma maneira mais complexa, muito mais ágil. As plataformas nos permite muito mais recurso para se contar uma historia. É uma maneira de se pensar o jornalismo em outras formas.

Entrevistador: Métricas têm influenciado na produção e na edição do conteúdo?

Com certeza até porque a gente sabe que audiência e os números mostram alguma coisa. Tem que saber deificá-los. Mas não devemos trabalhar só em função deles, mas eles são extremante importante dentro de uma redação.Por se tratar de uma percepção instantânea.

Entrevistador: A chegada de novos atores no processo de produção da noticia, tendem a alterar a tramitação do processo ou criar tensões?

Eu acho que já alterou. É uma realidade. Esses colaboradores tem sido fundamental para o jornalismo hoje em dia. Levando o próprio jornalista a pensar a maneira que se faz o 
jornalismo. E isso está se tornando algo interativo, que vai e vem. É difícil você trabalhar dentro de uma redação sem o conhecimento do designer. Já que a imagem é muito importante. Ajuda a compor a noticia. Quanto melhor você organiza o conteúdo, mais leitores você atrai e o mantém concentrado no conteúdo que está sendo apresentado.

Entrevistador: Você acredita que existe alguma tensão nesse dialogo?

Eu acredito que sim. Porque muito dos profissionais que estão dentro de uma redação, vem de uma cultura em que a escrita era muito forte. É difícil romper isso. Hoje o campo do jornalismo é muito amplo, e só a técnica, já não é tão importante. A profissão mostra muito mais que isso. 
Apêndice T - Editora Executiva Digital Diário do Nordeste

Entrevistador: O que faz uma diretora executiva de jornal?

Editora executiva digital do DN: Eu coordeno todo fluxo de conteúdo que são distribuídos entre as plataformas. Sempre dentro da seara do editorial. Tenho contato com o conteúdo do dia-a-dia através das reuniões (diárias e as terças) e tenho a função de perceber se esses conteúdos apresentam um potencial para se elaborar um editorial. O caso mais recente: a decisão do STF com relação às vaquejadas. É um assunto que gerou uma comoção em rede nacional, aqui no Ceará e que pode gerar um editorial. Penso sempre em uma forma de tornar uma pauta um assunto em discussão; e uma maneira de tornar o assunto em vídeo e mostra os ângulos do assunto.

Entrevistador: Isso é uma demanda da pauta? Potencial para se tornar um editorial.

EEDDN: Tem mais haver com a minha condução. Cada um têm seus devidos papeis. Suas devidas preocupações. Algumas vezes os próprios editores chegam a mim e fala: Olha tal assunto tem potencial para um editorial.

Entrevistador: O repórter tem autonomia para opinar nesse processo?

EEDDN: Tem. Mas você vai ver que depende do repórter. Vai ter o profissional que é mais passivo, o que questiona a pauta no momento da reunião e o repórter que é de outra editoria mais quando ver um assunto já fala- Olha, vocês poderiam falar disso aqui- depende muito profissional.

Entrevistador: o repórter sempre esteve á frente do processo de criação do conteúdo. Hoje, há outras figuras incluídas nesse processo. Você acha que existe um embate nessa nova relação?

EEDDN: Mais ou menos há uns dois atrás, tinha mais presença de profissionais que não eram jornalistas, e acontecia que alguns conteúdos aparentavam umas características que não faziam parte da editoria do jornal. Então notamos essas falhas, e tentamos corrigir. Hoje, é difícil pensar em qual profissional aqui da redação não é jornalista. Todos falam a mesma linguagem.

Entrevistador: O designer consegui alterar uma pauta ou sugerir?

EEDDN: Como é uma formação que é mais sensível a percepção visual e o que é possível fazer com essa é informação, e possível alterar a pauta através de uma conversa clara e objetiva.

Entrevistador: E com a TI?

EEDDN: Com a TI é uma dificuldade muito grande. E com elementos primários. 
Tipo a urgência. É muito difícil se fazer entender o peso quem tem de uma noticia ser corrigida, postada o mais urgente possível. Eu trabalho diretamente com a TI á mais de sete anos e esse é o maior problema que eu enfrento.

Entrevistador: Qual é o impacto das métricas no processo de criação?

EEDDN: Hoje nós temos duas ferramentas de métrica que pontuam a dinâmica da produção. A gente tem a koscaro (não entende muito bem) é uma ferramenta utilizada pela África, por exemplo. É a única métrica que você consegue enxergar os seus números e do seu concorrente, apesar de ter um deadline terrível. E outra é o Google analytics. A gente considera os números para sabermos qual o nosso posicionamento no mercado, mas não é levado tanto em conta para o direcionamento da nossa linha editorial. Nós ajuda dá uma direção para as áreas, tais como; crescer determinado conteúdo. O que influência diretamente para web. O que nos chama mais a atenção é as visitas quantitativas. A nossa média é de cada usuário ler em média 7,5 matérias. É meu papel ficar ligada nessa marcação, até porque eu apresento um determinado relatório para produção ao final do dia.

Entrevistador: Vocês trabalham com alguma métrica de crescimento?

EEDDN: Sim. A gente trabalha com um ciclo de seis meses. Por conta da sazonalidade dos fatos. Essas informações são dadas por dia e por semana..

Entrevistador: O que levou a transformação do antigo modelo para o Plus?

EEDDN: O principal motivo foi o usuário. Caiu o numero de usuários de tablet, a gente viu que o cenário que tínhamos no móvel era muito promissor. 
Apêndice U - Editor Executivo Diário do Nordeste

Entrevistador: Qual a sua função dentro da redação?

Editor executivo do DN: Coordenação e planejamento da edição. Tanto semanal quanto diária.

Entrevistador: Qual a função da pauta dentro do diário do nordeste?

Editor executivo do DN: Com a integração que fizemos a mais ou menos dois anos, a função da pauta é direcionar o que cada um vai fazer. De acordo com as reuniões a gente define qua pauta vai focar para cada plataforma: impresso ou digital.

Repórter- Quantas reuniões acontecem?

Editor executivo do DN: Tem um ás $10 \mathrm{~h}$ e às $16 \mathrm{~h}$. E acontece uma semanalmente todas as terças que a planejamento semanal.

Entrevistador: O digital tem preferência nesse processo de pauta?

Editor executivo do DN: Logo no começo era mais difícil as matérias irem para o digital. Quando as outras áreas começaram escrever para a plataforma digital, houve uma resistência, ainda existe, mais já é menor. Quase todas as matérias vão para o digital.

Entrevistador: Quem propõe as pautas?

Editor executivo do DN: Os editore dessa áreas e os chefes de editorias.

Repórter- O chefe de produção executa um papel próximo ao pauteiro?

Editor executivo do DN: Sim.

Entrevistador: Pauta restringe o trabalho do repórter?

Editor executivo do DN: Com a falta de questionamento e participação do repórter, a pauta pode funcionar como uma chefia para o repórter.

Entrevistador: O que seria a angulação de uma meteria?

Editor executivo do DN: É identificar o que é a pauta de um determinado assunto.

Entrevistador: De onde surgem as pautas?

Editor executivo do DN: Editores de área e chefias de produção. Do nosso contato com os leitores através do canal: Você é repórter. Pelo whatsaap

Entrevistador: Vocês utilizam alguma métrica?

Editor executivo do DN: A gente tem as métricas mais não utiliza muito. Mais para a web.

Repórter- O fato de vocês estarem dentro se uma redação convergente, implica de alguma forma no processo de produção?

Muitas vezes, principalmente a parte $\mathrm{d}$ arte e TI, muitas vezes a redação deixa de 
produzir um conteúdo por esbarrar no fluxo de arte ou programação.

Repórter- $\mathrm{O}$ editor acompanha o desenvolvimento da pauta junto ao repórter?

Isso é o padrão.

Repórter- As mídias sociais interferem de alguma forma no processo de construção do conteúdo?

Não. Só no digital. 
Apêndice V - Editor do Diário do Nordeste Plus

Repórter- Qual a nova proposta do diário nordestino?

Editor do Diário do Nordeste Plus: Desde de 2015, nos mudamos para web. Primeiro as vendas de tablet estavam caindo e essa mudança de mercado nos motivou a mudar o rumo das coisas. E a chegada do móbile foi altamente positiva e isso aumentou a nossa participação no mercado.

O que mudou, foi que ante, nos tínhamos uma participação diária, de segunda a sexta, que foi alterada para semanal com publicações somente nas segundas. As pautas continuaram mais ou menos iguais. Só que nos dependemos bastante da TI. Ainda não é possível trabalharmos na nossa velocidade. Algumas vezes dar certo outras não.

Repórter- Existe aquele compreensão do "laidbecker" (não entende muito bem a palavra) no final do dia? Isso tende interferir em alguma coisa?

Editor do Diário do Nordeste Plus: O plus é semanal como o jornal. Quando usávamos o plus antigo, você tinha esse negocio de avaliar no final do dia. Até pra ideia do que dava pra subir ou não, porém, isso não existe mas.

Repórer- Lembro que existia problema com o tamanho e formato?

EDNP: Nos tínhamos que ter uma imagem mais reduzida o vídeo também. Como a gente pensa no uso do smartfone com conectividade móvel, temos que ter cuidado com o tamanho das imagens e vídeos. Mas percebemos que mais da metade dos usuários do Plus acessa com conexões fixas. Mas temos o cuidado de mandar pacotes pequenos pensando em pessoa que acessam a partir de redes moveis.

Repórter- Quem propõe as pautas?

EDNP: Temos uma reunião semanal em que eu, os repórteres, o pessoal da arte ou estagiários podem apresentar ideia. Eu estimulo a participação de todos. O que acaba resultando em um conteúdo diversificado.

Repórter- Qual a função da pauta?

EDNP: Na minha visão, e pensar em materiais que você vá publicar. Nós estamos trabalhando de uma forma que ao final do mês, nós termos falado dos mais diversificados assuntos.

Repórter- O que é levado em consideração para uma pauta ser aprovada?

EDNP: Primeira coisa: é ser um assunto relevante. Tem que ter uma historia interessante para ser contada. Tentamos colocar temas que sejam legais para discussão. A questão é pensar em uma matéria que dure por muito mais tempo. Ela vai para o ar hoje, 
porém, é um assunto que vai ter uma repercussão de mais ou menos 1 um mês.

Aqui tivemos o exemplo da tatuagem: Uma matéria que falava sobre o mercado da tatuagem aqui em Fortaleza, e sempre que alguém procurava um lugar apara fazer a sua, acabava caindo em nossa matéria.

Pensar em como nós podemos enriquecer aquele conteúdo, como é para internet, é bacana você ter uma coisa além do texto. São coisas que são discutidas na reunião de pauta.

Repórter- A pauta restringe o trabalho do repórter?

EDNP: Não e sim. É como em monografia: tem que traçar um objetivo para não se perder. Um assunto é amplo, mas não dar pra falar de tudo.

Eu acho que essa e a função da pauta: delimitar a abrangência do assunto.

Repórter- Existe a possibilidade de a pauta cair?

EDNP: Existe. Às vezes você pensa uma realidade e na pratica é outra. Ou quando você sai para pré apuração você ver que aquele assunto não vai render foto nem vídeo. Daí já cai a pauta. Não dá pra ser só o texto.

Uma possibilidade é quando nós levamos para o editor e ele fala que não é um bom momento para tocar no assunto, as vezes por questões políticas ou então ele não acha relevante.

Repórter- O que seria uma angulação da pauta?

EDNP: Eu acho que é escolher o melhor ângulo daquele assunto. É delimitar o assunto.

Repórter- O que leva essa busca de tantas angulações? Existe temas mais importantes?

EDNP: O que existe são temas que são mais abrangentes. Se você escolher três aspectos distintos ainda não vai falar de tudo que o tema engloba.

Podemos falar de vários temas, mas temos que ter um objetivo definido. Ter a preocupação de não se estender demais e criar um conteúdo chato ou pesado.

Repórter- De onde sujem as pautas?

EDNP: Elas costumam surgir da cabeça da gente. Da nossa experiência, vivencia do mundo, algum assunto que surgiu nas redes socias, conversas.

Repórter- Outros atores que não sejam jornalistas interferem na produção da pauta?

EDNP: Não. Nós temos uma participação de todos, todos contribuem da melhor forma possível, as vezes alertando para as possíveis falhas que possam ter na pauta ou com novas ideias pra deixar o trabalho mais rico.

Repórter- Existe alguma tensão na relação com esses profissionais?

EDNP: Não. Costuma ser uma relação tranquila. Aqui eu trabalho diretamente com a 
Vanessa, apesar de ela ser da área da criação, ela já estar incluída a muito tempo no ambiente da redação. Ela da uma visão de conteúdo para aquela produção.

Repórter- O Editor acompanha o processo de desenvolvimento da pauta?

EDNP: Sim, o tempo todo. Com o pessoal da TI principalmente, que não gosta muito de fazer algum tipo de alteração após ter iniciado o processo de montagem.

Repórter- O repórter altera a pauta. Ele comunica ao editor?

EDNP: Ele só pode alterar durante reunião ao na hora da apuração.

Repórter- Como a comunicação é feita?

EDNP: Pessoalmente, por celular ou email.

Repórter- Existe algum software para controlar essa produção?

EDNP: Não.

Repórter- Processo de edição altera a pauta?

EDNP: As vezes quando o texto está finalizado e você vai editar, você enxerga melhor a localização de cada peça. Ela não altera a pauta, mas a forma que o conteúdo vai ser vista pelo leitor.

Repórter- As mídias socias influenciam de alguma forma a produção?

EDNP: Elas servem para compartilha as pautas com os leitores. Elas também servem para recebemos um feedback dos leitores, uma critica para o seu conteúdo.

Repórter- A audiência interfere de alguma forma no processo de produção?

EDNP: Nosso conteúdo já é meio que direcionado para um determinado publico o que acontece é que, depois do material distribuído, nós fazemos uma medição com relação a aceitação daquele conteúdo.

Repórter- O fato de a redação ser convergente, que produz para varias suportes, tem algum impacto no processo de produção?

EDNP: No início do projeto, o pessoal do impresso escrevia para o digital, acabava ficando um conteúdo repetitivo, hoje, o que está no online não vai para impresso. Não tem muita essa conversa. 
Apêndice W - Repórter do Diário do Nordeste Plus

Entrevistador: Você sugere pauta?

Repórter do DN: Sim, meus editores sempre foram muito abertos. A gente costuma sugerir pauta que tem mais afinidade. Mas às vezes, não

Entrevistador: De onde surgem as pautas?

Repórter do DN: Eu gosto muito de acompanhar a rede social principalmente a questão de comportamento.

Entrevistador: Como é feita a pauta?

Repórter do DN: Temos reunião todas às segundas-feiras, com toda equipe e vai surgindo um bate-papo.

Entrevistador: Existem elementos que devem conter na pauta?

Repórter do DN: Não, mas é sempre bom ter opção de vídeo, algum tipo de arte ou interação.

Entrevistador: Existe possibilidade de pauta cair?

Repórter do DN: Sim, às vezes bate com assuntos de outro caderno. Como o diário Plus abrange vários assuntos, é muito comum isso acontecer.

Entrevistador: Qual importância da angulação da pauta?

Repórter do DN: Eu acredito que é a partir do enfoque que você vai conseguir conquistar o leitor. Eu prefiro focar na parte que eu considero mais interessante, que eu acho que vá chamar a atenção do leitor.

Entrevistador: O repórter é obrigado a comunicar qualquer processo de alteração na pauta?

Repórter do DN: Eu gosto de comunicar. Acho interessante..

Entrevistador: Por se tratar de um suporte móvel, a pauta precisa ter algum elemento diferenciado?

Repórter do DN: A gente tenta sempre ter vídeo e galeria de imagem.

Entrevistador: a chegada de novos profissionais tende a alterar o processo de criação da noticia?

Repórter do DN: Eu acho que contribui para uma matéria mais rica e detalhada.

Entrevistador: Você acha que existe alguma tensão nesse processo?

Repórter do DN: Não, para eles é só alguma coisa que você tem que fazer no seu diadia.

Entrevistador: As mídias socias interferem na produção? 
Repórter do DN: No meu caso, influencia na elaboração de pautas. Eu costumo observa os assuntos que estão sendo discutidos e a partir dali, extrair algum conteúdo.

Entrevistador: Além de texto, você produz algum outro formato?

Repórter do DN: Vídeo, quando precisa, e foto.

Entrevistador: Você utiliza algum critério para escolher um formato?

Repórter do DN: Isso já meio que instituído. A eu acho que imagem é indispensável.

Entrevistador: Existem fontes que se adéquam melhor pra esse formato?

Repórter do DN: Não, é mesma coisa.

Entrevistador: Você utiliza alguma base de dados?

Repórter do DN: Temos um arquivo.

Entrevistador: Você utiliza alguma métrica?

Repórter do DN: O editor tem acesso ao Google analític e ele costuma monitorar esses números.

Entrevistador: Existe algum tamanho pra construção do texto?

Repórter do DN: Não. Não há um padrão

Entrevistador: $\mathrm{O}$ fato de vocês estarem dentro se uma redação convergente, implica de alguma forma no processo de produção?

Repórter do DN: Na verdade eu acho que facilita. O pessoal do impresso, por estarem aqui dentro há muito mais tempo, ajuda na hora de tirar alguma duvida. 
Apêndice X - Editor do Diário do Nordeste Plus - entrevista feita em 23-03-2015 - antes das mudanças do aplicativo.

Entrevistador: Como são sugeridos e quais são os critérios que são utilizados para escolha dos temas que estarão presentes nas pautas do Plus?

Editor: As pautas são o seguinte: eu dou algumas sugestões, a equipe toda tem liberdade para sugerir pautas, sugerir nomes, porque a gente tem algumas edições especiais que tem um conteúdo, como "Novos Sons", que são bandas que estão se destacando no Ceará, personalidades do estado, não necessariamente são personalidades conhecidas, mas são pessoas, a Leor da pimenta, dona Leor, que é uma mulher que faz uma pimenta muito boa lá no Mercado Central, então ela não é uma pessoa que sai nas colunas sociais, mas é uma pessoa que é conhecida na cidade, então vamos falar um pouco da história dela. Tem pautas que eu sugiro e tem pautas que o resto da equipe sugere, ou então uma pauta que alguém na reunião de pauta geral sugere, "olha isso aqui é interessante pro Plus", e aí a gente vai lá e faz. Então, assim, dessa forma que são as pautas.

Entrevistador: Como é que são feitas as reuniões, a periodicidade?

E: Toda segunda-feira a gente tenta manter, às vezes tem semana que não dá porque tem gente viajando, ou está doente, então a gente tenta fazer a reunião com todos presentes para que todos possam opinar, comentar, falar e dizer se acham que a pauta cabe, ou se não cabe.

Entrevistador:E existe um modelo pra essa pauta? Elas são apresentadas oralmente, escritas?

E: Não, a pessoa falar, a gente anota ali, discute, vê o que pode ser feito em termos de interação, de conteúdos mais interativos, e verifica se aquele tema que a gente pensou é realmente viável pro Plus, se vai ter interação, porque às vezes é um tema muito legal, só que não tem interação, não tem vídeo, não tem foto, é um assunto que não tem como a gente discutir aqui em Fortolaze, porque só está lá em São Paulo, aí vai ter que morrer.

Entrevistador: Então você quer dizer que as características do tablet são levadas em conta para escolher um tema.

E: Sim. O tablet, pra nossa realidade aqui, nós temos que produzir assuntos que nós possamos ter recurso na interação, vídeo, foto, texto, tudo tem que estar com possibilidade da gente conseguir, porque, por exemplo, essa pauta do menino, do cearense que está em São Paulo do Lo (3:15 - Conferir se é 'do Lo' mesmo), ela teve um dificultador que foi a foto, ela ainda não mandou a foto, o rapaz, e a gente vai acabar usando a foto do Facebook, não vai 
ficar perfeito como se fosse dele aqui, se a gente pudesse ir na casa dele fazer, então isso é um dificultador, isso pode atrapalhar um pouco a resolução da pauta. A gente acabou de fazer, apostando que ia ter as fotos, vai ter um pouco atrasado, mas vai ter, então isso é um dificultador. Às vezes a pauta tem que ser derrubada porque ela vai causar um transtorno na edição, a gente vai perder muito tempo, e não vai sair um conteúdo interessante.

Entrevistador: Por ser um dispositivo que tem alta resolução então isso acaba de alguma forma...

E: É, ainda tem esse detalhe também, se as fotos e vídeos, que a gente passou por um processo de reformulação gráfica, para privilegiar a questão da imagem, então isso tem que ser analisado na hora da pauta, ter imagens de qualidade.

Entrevistador: Vocês acompanham algum tipo de métrica pra escolher pauta, ou pra alguma temática ser abordada?

E: Não, a gente não é, nosso conteúdo não é, como eu posso dizer, ele não é temporal, ele é atemporal, então a gente não tem a preocupação de estar focado numa data, lógico que às vezes tem eventos que pedem que a gente participe com algum material, como foi a Copa do Mundo, a Copa das Confederações, as eleições, então tem assuntos que a gente acaba usando aquela semana, usando aquela data pra fazer o material, mas a gente não fica muito ligado à esses assuntos temporais não, nosso conteúdo é um conteúdo mais planejado com antecedência. Pode até ser assim, vai ter uma semana, assim, dezembro a gente vai ter o sétimo Star Wars, a gente pode nessa semana trazer alguma coisa, alguma matéria especial sobre a saga, mas a gente não se prende a isso não.

Entrevistador: E as mídias sociais exercem alguma influencia nesse processo de produção?

E: As mídias sociais, quando tem algum tema interessante, por exemplo, teve um, acho que no Facebook de um rapaz, um jornalista, ele criou, acho que foi num Blog, ele falava sobre as ruas de Fortaleza, e ele começou a colocar no Facebook, fez um Facebook só pra colocar sobre as ruas de Fortaleza, falando as histórias, a gente achou interessante aquilo e resolver fazer uma matéria. Mas não necessariamente tudo que está nas redes sociais vai para o Plus, mas algumas coisas podem ser interessantes a ponto de entrar aí, tinha muitas fotos histórias, então foi um material que deu pra fazer, mas não é todo material que vai, exatamente pela questão das imagens, às vezes é legal o assunto, mas não tem foto.

Entrevistador: Os repórteres vão à campo apurar?

E: Vão, aqui o pessoal sai bastante, a Ingrid, a Bruna e a Luísa vão muito pra rua, elas também fazer material por telefone, mas vão bastante pra rua. 
Entrevistador: Quais são as ferramentas que são utilizadas nesse processo de produção? E aí eu estou falando de uma coisa bem ampla, do Windesign ao computador.

E: É, a gente usa os iPhones, quando é um material como o do "Novos Sons", aí a gente chama o pessoal da TVDN pra fazer tipo um mini documentário, às vezes a gente consegue fazer um mini documentário, com a handcam HD, e eles editam lá, às vezes por telefone, às vezes por e-mail, às vezes vai só o fotógrafo fazer a foto e a pessoa já fala por telefone ou por e-mail com o entrevistado, já teve pauta que a gente viajou pra outro lugar e trouxe material. E aqui as meninas trabalham com o Windesign e com RDP, né, pra poder editar o material.

Entrevistador: Os repórteres usam também o Windesign?

E: Não, assim, basicamente só pra editar um material como panorama, que é um material mais curto, ou pra mudar alguma coisinha no texto, já está quase tudo pronto, entra lá e faz uma modificação.

Entrevistador: Vocês utilizam alguma base de dados pra produzir informação?

E: Nós usamos pra escrever, geralmente, o docs do Google, porque aí todo mundo pode acessar, você pode compartilhar, pode mexer lá e tudo mais, e fica um material guardado lá. Nós temos aqui no jornal um sistema de banco de imagens, que é esse $(8: 24 s-$ Nome do sistema), que pega as fotos aqui, procura as fotos aqui. E tem esse outro que é mais antigo que é o CIA, Controle Informativo de Arquivos, ele é até 2011, então as fotos nem todas estão em alta resolução.

Entrevistador: Por serem consumidas em um aparelho móvel, isso impacta de alguma forma nessa informação que é produzida, nesse conteúdo?

E: Na qualidade você fala?

Entrevistador: Não, eu digo, olha, você está produzindo um conteúdo para um dispositivo móvel, isso vai impactar de alguma forma pra você repórter, pra você editor na hora da produção?

E: Não, acho que...

Entrevistador: O repórter tem alguma orientação nesse sentido?

D: Você fala os nossos ou outros?

Entrevistador: Os que vão produzir no Plus.

E: Não, quando ele vai produzir pro Plus, a orientação no caso é estar com um iPhone ou um iPad pra fazer o material, é tentar ter um pouco mais de paciência pra pode produzir uma foto boa, o iPhone não tem uma resolução de imagem tão boa quanto uma câmera profissional, né, dá pra fazer uma foto e tudo mais, mas não aquela foto, principalmente em 
movimento, então a gente tem que ter um pouco mais de cuidado. Tem os vídeos que quando é um vídeo como uma entrevista, dá pra fazer no iPhone, se for um vídeo como eu falei do "Novos Sons", que é como se fosse mini doc, é importante ter o pessoal da TVDN pra fazer com a handcam, fazer um contraponto, que a imagem fica melhor, até pra fazer um videozinho, um vídeo clip, no mais não tem nenhum problema.

Entrevistador: No conteúdo publicado no Plus, há aproveitamento de outro conteúdo dos outros suportes do jornal?

E: Olha, no panorama, o panorama é um resumo das notícias que saíram no dia no nosso portal, então é um resumo bem resumido mesmo do material que está no online, o restante não. A gente fez uma reformulação inclusive, porque as colunas eram antecipadas no Plus, a gente chegou a conclusão de que não era interessante, a pessoa ia ver o jornal impresso, não ia ter atrativo nenhum, então o que a gente fez foi transformar a maioria das colunas, e tinha um caráter opinativo, em vídeo, que é mais ou menos dois minutos, dois minutos e meio, em que o colunista trata de um assunto, um assunto mais quente do dia, e ele faz aquele discurso no vídeo, e aí a gente não tem a coluna repetida, então você ganha um conteúdo a mais, não perde um conteúdo, então a gente acabou fazendo isso. Matérias, nossas matérias vão pro impresso e pro online, a gente não tem mais matéria deles com a gente, muito raro, a não ser que tenha um material muito especial lá, mas muito especial mesmo, que digamos não tenha como ir todo lá e eles negociam pra gente aproveitar esse resto de conteúdo.

(Entrevista é interrompida para o editor responder à alguém)

A gente estava falando do?

Entrevistador: Do aproveitamento, mas foi ótimo.

E: Do aproveitamento, mas a gente praticamente não aproveita nada.

Entrevistador: Existe algum planejamento prévio da arquitetura da informação? Você estava me falando, mas acho que você vai desenvolver.

E: Não, pode deixar, já encerramos aquela. Não, existe um planejamento, a gente meio que, a Marina e a Vanessa, quando a gente está conversando aqui, elas já meio que pensam como é que vão fazer essa página, só que às vezes, como deu agora, há um problema de foto, às vezes as fotos a gente tinha certeza que estavam ótimas, quando a gente vai colocar pro tablet elas não estão ótimas, e aí as meninas fazem uma mágica aí, no departamento de imagem, pra salvar aquela foto, salvar o que a gente tinha pré-planejado e aí se não tiver jeito vai ter que refazer todo o planejamento anterior.

Entrevistador : Eu vi as meninas falando de blocos, de box, e aí eu fiquei imaginando 
se não seriam camadas em hipertexto pra navegação, box seria algo que você clicasse pra ver.

Entrevistador: Certo. Quais são os critérios que são utilizados para a construção desse hipertexto?

E: Aí a gente vai fazer da seguinte forma, a gente pensa o texto principal, depois de pensar o texto principal a gente pensa partículas de informações que são importantes, mas que a gente pode não colocar corrido no texto, mas a gente pode saltar, por exemplo, está vendo aquela imagem do menino ali?

De repente quando clica nele abre um textinho, uma frasesinha que era interessante, que a gente achou marcante, então ela vai ali. Ou então você clica num link de vídeo que está no meio da matéria e abre um vídeo dele, falando da vida dele, como é que ele chegou a ir pra São Paulo, se sente falta da família e tudo mais. Então, assim, depende também de que tipo de matéria, às vezes a matéria fala sobre culinária, e aí a gente faz um desenho de um prato com alguns tipos de comida, e nessas comidas a pessoa clica, tem um íconezinho que ela vai saber que tem que clicar, e aí ao clicar abre um pop up com texto, com vídeo, então vai depender também da matéria. A gente pode trabalhar com referências daquela matéria, comida, como eu falei, esporte, a bola de futebol, a bola de vôlei, você clica lá e abre alguma coisa sobre futebol, alguma coisa sobre vôlei, então a gente trabalha bastante em cima da imagem também, transforma ícones em algo clicável.

Entrevistador: Então existe uma preocupação com a interatividade, que o usuário tenha uma experiência interativa?

E: Sim, com certeza, a gente procura no Plus se preocupar não só com o texto, mas em fazer ele usar o máximo de recursos que o iPad, no caso, possa oferecer. Então a gente tenta pensar que tipo de ícones, que tipo de formatos, pede pra ele deitar, pede pra ele rolar, pede pra ele clicar, então a gente tenta usar o máximo de recursos que é possível de se fazer no iPad.

Entrevistador: Existe alguma previsão pra uso de customização de conteúdo? Customização tem vários níveis, né, mas customizar, reconhecer o usuário e oferecer algum conteúdo pra ele.

E: Essa questão de reconhecer o usuário, ou de reconhecer onde ele está, a gente tem uma idéia de como usar isso, já foi até demonstrado, por exemplo, num anúncio, se a pessoa abrir o anúncio de manhã, digamos da faculdade, "Que tal se matricular, no turno da manhã nós temos essas vagas", mas foi pensado mais na questão comercial, por enquanto, né, você está abrindo o jornal ou o Plus no tablet a noite, apareceu um anúncio de um restaurante, "vamos jantar no restaurante tal, desconto pra você", por enquanto foi pensado alguma coisa 
desse tipo comercialmente, não se chegou a pensa na questão editorial.

Entrevistador: A memória é utilizada em algum momento na construção da informação?

\section{E: A memória?}

Entrevistador: É, a memória do que foi produzido.

E: Olha, todo o conteúdo nós temos guardado, e muitas vezes a gente tenta com aquelas informações que ficaram pra trás, melhorar o conteúdo atual, e não repetir. Acho que tem uma proporção muito forte de não repetir não só o conteúdo, mas não repetir os desenhos das páginas, quando as meninas tem ali, elas tem vários modelos pra elas pensarem, então elas tem a capacidade de ver os modelos mais recentes, por exemplo, e não repetir formatos, não repetir diagramações, e isso é importante pra pessoa não ficar achando que é o mesmo conteúdo, né.

Entrevistador: Existe alguma orientação, existe um tamanho aconselhado para o texto?

E: A gente procura que seja uma lauda e meia, espaçamento 1,5, mas tem gente que consegue, tem gente que não consegue.

Entrevistador: Mas existe uma orientação pro tamanho, número de textos publicados por dia?

E: Não, é uma matéria principal todo dia e os outros são colunas, então é só a matéria principal, essa matéria principal o ideal é que fosse uma lauda e meia, espaçamento duplo e uma coordenada e uns box. É, e aí quando é personagem os repórteres até gostam porque dá pra aumentar o texto, a gente vira, faz umas brincadeiras lá que corta menos o texto deles.

entrevistador: E como é que são escolhidos os formatos midiáticos? Por que usa o vídeo e por que não o áudio?

E: O áudio acho que é raríssimo a gente usar, acho que só quando é música e a banda não tem um vídeo legal, mas é bem mais usado o vídeo. Acho que porque o vídeo é mais interessante, a pessoa vê, tem o visual da coisa, além de ouvir. É, depende do que você tem de conteúdo. Às vezes a entrevista dele é só ele sentado aqui, aí você pode usar dentro do texto, às vezes não, você está lá o cara está demonstrando como abrir o computador e trocar aquela peça, é muita mais interessante você ver como que faz isso do que você ler como que faz isso. Essa orientação vale pra quase tudo, por exemplo, foto, a não ser que a pessoa seja extremamente famosa, um rosto conhecido, ou que ela seja modelo e dependa do rosto dela pra aquilo, não vale muito a pena você caracterizar a pessoa, né, aí a pessoa foi fonte da matéria só pra colocar o rosto dela lá, então a gente procura direcionar, pessoa mexendo no computador, sei lá, sendo informação e não... 
Não sendo só uma foto $3 \times 4$, sendo uma foto de alguma coisa.

Entrevistador: E esse arquivos, vamos dizer que eu escolhi fazer um vídeo, onde é feita a sessão?

E: Bom, você produz o vídeo, o repórter produz o vídeo, leva lá na TVDN com a Fernanda, que veio aqui, e ela e a equipe dela vão fazer essa edição.

Entrevistador: Certo, os repórteres não tratam esse conteúdo aqui.

E: Não, eles no máximo vão fazer uma decupagem, não vão editar.

Entrevistador: Existe algum manual que oriente a edição deste conteúdo?

E: Do vídeo?

Entrevistador: Conteúdo jornalístico.

E: Não, a gente tem um manual pra diagramação...

Entrevistador: Certo, que é o projeto gráfico.

E: Isso, que é o projeto gráfico, então a gente tem o nosso projeto gráfico aqui também, mas a gente não tem um manual de como, aliás, tem um manual de como escrever pra web, que pode ser adaptável pra cá, mas a gente não tem um manual de como escrever no Plus.

Entrevistador: Mas vocês seguem algum modelo de produção textual, vamos dizer assim: ah eu uso a pirâmide invertida.

E: Não, a gente usa um modelo que foi desenvolvido pra redação, pra redação que eu falo do online, tentando incentivar as pessoas do impresso, então a gente segue um pouco essa orientação.

Entrevistador: Certo. Vocês tem alguma previsão, alguma preocupação de uso de geolocalização na produção do conteúdo?

E: A gente tinha nos aplicativos de smartphone, mas no iPad não, aí vai entrar mais uma vez aquela questão do comercial, ta se pensando em fazer isso, os anúncios, mas até agora não tem quando vai ser feito isso.

Só fazer uma observação, no caso da geolocalização, até mesmo da questão de horário, a gente tem um pouco de limitação de tempo, porque a gente tem uma edição diária, ou seja, a gente não consegue parar pra fazer algo que requeira isso...

E: Até já teve alguns mapas, né, mas não é um negócio que... E também com a ferramenta, a gente tem uma ferramenta que também é limitante da gente, então a gente precisaria de programação pra fazer a geolocalização, então tem esses dois recursos que a gente tem que pesar pra fazer, mas é possível.

Entrevistador: Qual é o horário do fechamento de vocês? 
E: Geralmente a gente fecha às $19 \mathrm{~h}$, mas como a Vanessa falou, às vezes a gente tem alguns contratempos aí com o nosso RDP.

Entrevistador: Só uma dúvida, qual é a função do editor aqui no Plus?

E: A função do editor, bom, o editor aqui ele tem que pautar, tem que participar da edição, tem que corrigir os textos, tem que conversar com os repórteres, conversar com a diagramação, acho que faz um bocado de coisa, assim como todos nós fazemos, porque assim, a gente não tem, as meninas, repórteres, também participam conversando com a Vanessa e a Marina, então tem bastante essa troca, tem também a sugestão de pauta delas, elas podem sugerir, e no mais, talvez o que elas ainda não façam $100 \%$ das vezes, é a correção, a orientação, ficar atrás de fotógrafo, tentar resolver problemas administrativos que a gente também tem que fazer, que é ir atrás de carro, atrás de fotógrafo, atrás do Berlamindo, que entrou, pra fazer algum infográfico. Então tem uma função administrativa além da função jornalística de pautar, de resolver, de corrigir.

Entrevistador: E quais são as competências básicas para ser um repórter do Plus?

E: Bom, repórter no Plus primeiro não pode ter preguiça, se não ele está meio complicado, porque ele vai pra rua, ele vai desenvolver a pauta dele, ele tem que pensar na foto, tem que pensar no vídeo, tem que ter uma idéia de como vai ser desenhado o texto dele pra conversar com as meninas, conversar comigo, ele tem que ter capacidade para pensar em assuntos relevantes pra trazer pra edição. Ele tem que ser uma pessoa que não tem preconceito com todos os assuntos, porque às vezes você está fazendo uma coisa que você gosta muito, por exemplo, esporte, às vezes a pessoa do esporte não gosta de matéria de cultural e aí vai ter que fazer matéria de cultural, porque a nossa equipe é muito pequena pra ter uma pessoa só pra fazer um assunto, então ela precisa não ter preconceito e também querer entender os assuntos, ler e ir atrás de se informas pra escrever a pauta.

Entrevistador: Tem que ter alguma competência técnica?

E: Ter um bom texto, entender minimamente de diagramação, não falo nem de diagramar em si, mas de localizar como é que vai dividir o texto, acho que isso é importante. 
Apêndice Y - Repórter do Diário do Nordeste Plus - entrevista feita em 23/03/2015 - antes das mudanças do aplicativo.

Entrevistador: qual é a função do repórter no Plus?

Repórter: A função do repórter? A função do repórter é, nu e crua, desenvolver o conteúdo, né? Além disso, aqui, especificamente no Plus, a gente tem que pensar... Por que assim, na redação normalmente você é pautado, algumas vezes você pode dar sugestão, mas o que acontece é que você é mais pautado. Aqui não, a gente vai dar sugestão e a gente tem que dar umas sugestões. E não pensar só no texto, até porque as pautas aqui não são tão factuais. Então a gente tem que pensar em como fazer a pauta, o que essa pauta pode ter, pode ter uma arte, como vai ser feita essa arte? Porque às vezes eu penso numa coisa, aí eu chego aqui na reunião das pautas e falo pras meninas "eu quero fazer isso", aí elas falam "não dá pra fazer isso por causa disso e daquilo", como elas falaram, diversos fatores, questão de tempo, nossa produção é diária, questão das ferramentas que a gente tem disponível. Então além de você pensar essa questão, você tem que pensar em como você vai colocar aqui ali, o que você pode colocar, um vídeo, uma arte, vídeo do que, enfim.

E: Quais são as competências que você considera necessárias para atuar aqui?

$\mathrm{R}$ : Eu acho que é ter esse olhar, entendeu? Eu acho que é ter esse olhar e de não, assim, eu até tento praticar um pouco disso, é de você não ter aquele olhar do mesmo, porque assim se você pegar um jornal, pegar o caderno de economia, as matérias praticamente se repetem, cidade, se repetem. Então aqui você tem que ter um olhar diferenciado, tanto de conteúdo, de produção, de interatividade, é exatamente esse olhar que eu acho, tem que manjar um pouco dessas ferramentas também.

E: E quais são as ferramentas que você utiliza para produção?

R: Ferramentas que utilizem o que, programas?

E: Programas.

R: A gente utiliza o que, vamos lá, material: a gente usa câmeras, celulares, quando a gente estava fazendo vídeos, aí no caso a gente só usa o drive, que é o que a gente escreve, e bloco de notas. O que a gente usa mais mesmo, como ferramenta principal, é a nossa cabecinha pra gente pensar em como que a gente tem que desenvolver.

E: E como é que você propõe suas pautas? Como é que elas chegam?

R: Por exemplo, uma curiosidade, um assunto que você não vê que é muito discutido e que você tem vontade de discutir. E um assunto que aqui que pode render, que pode ter uma abordagem diferente, porque aqui no Plus um assunto pode ser muito rico, justamente devido 
à essa interatividade que o projeto permite, entendeu?

E: E você tem preocupação com as características do tablet?

R: Tenho, nem sempre eu consigo, é por isso que eu peço muita ajuda das meninas, “gente, vem cá, como é que eu posso fazer isso aqui?", porque o olhar delas é um olhar diferente do meu olhar, por formação e por experiência, né, de vida, enfim, elas são diferentes. Então eu sempre penso em como eu posso fazer isso aqui, como vai ficar melhor, entendeu?

E: E as mídias sociais exercem alguma influência nessa sua procura, nessa sua escolha quando você vai sugerir algo?

R: Sinceramente eu acho mais em questão de pauta. Só assim, uma sugestão de pauta que eu acho interessante, mas assim, pra cá não muito, raro. Usamos algumas vezes para contactar fontes.

E: Eu vi todo mundo usando.

R: Foi.

E: É normal.

R: É normal, porque como eu venho de lá, isso ali já era normal, aqui eu não digo pra mim que isso é uma coisa muito do Plus, porque lá a gente era assim. É porque assim, a veiculação aqui por rede social não, mas é muito mais instrumento de pesquisa, de fonte.

R: Justamente, é instrumento de trabalho

E: Muda alguma coisa no processo de apuração? Quando você está no Plus você percebe que tem alguma alteração?

R: Não, acho que só assim, na hora que a gente está fazendo, muitas fontes não conhecem, não sabem como que é, então a gente tem que explicar que a gente vai ter um viés diferente daquele tradicional que eles estão acostumados a ver, então a gente tem que explicar esse novo formato.

E: Certo. Além do texto você produz em algum outro formato?

R: Vídeo, a gente faz vídeo, é comum a gente fazer vídeo, vídeo, texto...

E: E qual o critério que você utiliza em detrimento de um do outro?

R: Pois é, a gente, como as meninas até falaram, a gente procura não repetir, tipo assim, a gente olha "isso aqui vai ficar melhor em vídeo ou em texto?", como até o Daniel estava falando, aquela questão de você demonstrar um vídeo ou você escrever. Esse mesmo critério se aplica às artes, né, que linguagem ficaria melhor, então, assim, é basicamente ver qual discurso eu estou falando pra ver o que eu vou escolher.

E: repórter produz gráfico ou infográfico? 
R: Produz, acredito que produza.

E: Vocês fazem?

R: Não, a gente pensa, né, as meninas que botam a mão na massa mesmo, mas a gente procura pensar. Quando tem uma matéria com muitos números, ou algo do tipo, alguma informação que seja melhor, a gente usa até pouco aqui, usa mais ou menos.

E: O suporte, na hora em que você vai escolher uma fonte o suporte é levado em consideração? Você pensa "ah, eu estou escrevendo pro Plus"?

$\mathrm{R}$ : Sim, sim porque eu acho que é um produto novo

E: Aham, e a fonte...

R: Às vezes não conhece, não sabe muito bem, então eu acho que tem que...

Entrevistador: Mas existe uma fonte melhor do que a outra?

R: Pro Plus?

E: É, eu digo isso, eu estou fazendo uma matéria pro Plus, então eu tenho uma fonte que é melhor pra esse suporte?

R: Não, não, muito raro. A não ser assim, por exemplo, se for fazer de um assunto específico e ela já tiver tido vivência, tecnologia, alguma coisa assim.

E: Você utiliza alguma base de dados pra produção de seu conteúdo?

R: Pesquisas, pesquisas.

E: Tem alguma disponível?

R: De que?

E:: Base de dados.

R: Não, só pesquisas mesmo.

E: Você costuma pensar na arquitetura da informação, como é que seu texto vai estar montado?

R: Penso, é porque isso aí vai de acordo muito com a minha pauta, vai de acordo com o estilo que eu estou escrevendo, eu faço de acordo com o assunto, como é que o assunto vai me puxar pra aquilo ali, então eu vou colocando as informações de acordo com o tipo de matéria que eu estou escrevendo. Que até porque vai variar, né, dependendo do assunto vai variar.

E: Você utilizando link?

R: Sim, sim.

E: Então qual o critério que você utiliza pra inserir um link na matéria?

R: Se a gente está falando de alguma coisa que tem link, as meninas linkam.

Entrevistador: Mas você que escolhe o local, você diz, você pensa o que vai seguir? 
$\mathrm{R}$ : Na hora que edito o texto as meninas...

E: Certo, certo. Você tem preocupação com interatividade da matéria?

R: Sim, já tinha dito, a gente sempre discute aqui. Tem que ter, né, é necessário, para o que a gente faz é totalmente necessário.

E: Por você estar dentro de uma redação, não sei se eu chamaria de convergente, mas em contato com outros colegas, de outras áreas, isso passa a impactar de alguma forma no seu trabalho? Por que tem pessoas do impresso, tem pessoas da TV, isso influencia na forma que vocês estão produzindo?

$\mathrm{R}:$ Eu acho que mais o inverso, acredito que seja muito o inverso, mas...

E: Você tem noção de que, de como?

$\mathrm{R}$ : Eu acho que muito de como que a gente trabalha, entendeu? Eu acho que é muito assim de como que a gente trabalha.

E: Certo, e no processo de produção da notícia, você percebe alguma alteração?

R: Não, muito pouco.

E: Você acha que continua fazendo a mesma coisa? Eu estou falando de coleta, de edição, de toda a produção.

R: Assim, eu acho que o que muda é na hora de pensar o que a gente vai fazer, mas assim, a gente vai coletar as informações da mesma forma, a base do jornalismo não se perde, agora como a gente está fazendo, como a gente vai montar, como a gente vai fazer aquilo ali, estruturar, aí vai mudar com certeza, sem dúvidas, né. 
Apêndice Z - Editora Assistente do Diário do Nordeste Plus - entrevista feita em 23/03/2015 - antes das mudanças do aplicativo.

Entrevistador: Você produz matérias?

EA: Também, produzo.

E: Então eu vou fazer mais ou menos as perguntas como se você fosse repórter. Qual é a função do repórter no Plus?

EA: Bom, repórter do Plus ele... Quer que eu compare com o impresso?

$\mathrm{E}: \mathrm{O}$ que você quiser.

EA: Tá, eu acho que aqui a gente tem o desafio de trazer conteúdo valendo texto, pensar em temas que a gente possa trabalhar interação, pensar também em fotos que sejam atrativas ao olhar de quem for acessar o conteúdo, trabalhar a questão do texto, como as meninas estavam falando, que eu acho que é o desafio para o repórter não escrever demais. É ter um olhar sobre o geral, texto, foto, vídeo, não é limitar o tema, mas transformar o tema para que ele seja atrativo na interatividade, então é um desafio sempre constante.

E: Certo. Quais são as competências que você considera necessárias para ser repórter do Plus?

EA: Acho que qualquer pessoa pode desenvolver essas competências se ela se propor a isso. Então tem que abrir a mente pra poder olhar o mundo com outros olhos, esse olhar aguçado, de curiosidade, de tentar ver o que seria interessante de desenvolver nessas plataformas, de texto, de vídeos, de foto, e procurar não se bloquear, não colocar limites nessas questões, né, e ir atrás mesmo do material, das fontes, e dali desenvolver as temáticas.

E: E como é feita a pauta? Qual é o assunto que se transforma em pauta? É diferente?

EA: A gente tem um perfil mais revista, né, então o que a gente procura, se você for ver ali na relação de pautas que a gente, são temas mais curiosos, culturais, da cultura local, temas que agucem a curiosidade das pessoas. Então, a questão da curiosidade, a gente tem essa seção de religiosidade, espiritualidade, que é uma que tem muita leitura, então a gente procura trabalhar temas como já foram trabalhados como maçonaria, candomblé, dissecar esses temas até tirar um pouco do tabu de certos assuntos, procurar a gente entrar nesses conteúdos mesmo. Outros que são bem regionais mesmo, como o Daniel estava falando da dona Oleor lá do mercado central de São Sebastião, quem é essa mulher por trás das pimentas, um pouco da humanidade das pessoas. E também a parte da tecnologia que também tem a ver com a temática. Aí também coisas factuais, por exemplo, a gente fez uma matéria um tempo desses que foi a questão dos "paus-de-selfie". Aí a gente faz um pouco de serviço, o que está 
em evidência, o que não está, questão de preço. A gente procura sempre essa parte cultural e comportamental o que a gente acha que pode ser interessante pro nosso leitor, trabalhando a questão da interatividade e a questão de imagem, apelo visual.

E: Certo. As mídias sociais exercem alguma influencia no processo de produção?

EA: Sim, eu sempre brinco com as meninas dizendo que eu não sei o que seria da gente sem o Facebook, porque auxilia muito a conseguir personagens, até porque a gente vive uma correria, é tudo muito louco, então as vezes você conhece uma pessoa e a pessoa me ajuda aqui com um personagem $X$, lógico que a gente não fica jogando pra todo mundo, porque a gente não vai ficar entregando a pauta da gente, às vezes por inbox uma pessoa te ajuda. E a gente também tem o Diarinho, que é pra criança, e a gente tem a fan page que a gente divulga muito o que a gente publica nessa fan page, até pra saber o feedback dos pais. Então, assim, as próprias matérias da gente a gente publica só um pedacinho no site, um pedacinho e quem quiser ver mais tem que baixar o aplicativo, aí a gente já vê a resposta do pessoal compartilhando esse pedacinho pelo Facebook, então é uma forma da gente ter um feedback do que a gente está fazendo, então ajuda bastante sim.

E: Você acha que teve alguma mudança no processo de apuração?

EA: Como assim?

E: Por estar produzindo para o Plus, no processo de apuração.

EA: Não, eu acho que é a mesma coisa, é a questão de você ir atrás da realidade, a gente só vai publicar aquilo que a gente ver que é aquilo mesmo, a gente não vai sair publicando uma coisa que a gente viu num site sem saber se é aquilo mesmo, a gente vai atrás de uma fonte oficial, e a base do jornalismo, que eu acho que não muda não.

E: O fato de ser uma interface tátil, isso influencia no modo em que você vai produzir a informação?

EA: Sim, porque, como a gente estava falando, a Marina falou até, que às vezes a gente tem uma certa dificuldade de escrever e de pensar peças, então a gente já tem que escrever pensando "ah, não, isso aqui fica melhor, talvez vamos transformar isso aqui pra pessoa tocar e aparecer uma outra aba, que fica mais didático, fica mais interativo", então você ter concepção de todas essas fases, do fazer, o Plus torna o resultado final mais produtivo do que você escrever linearmente. Então eu acredito que desenvolve-se aos poucos, ninguém chegou aqui já sabendo tudo, né, e a questão da gente conversar, ter essa facilidade de trocar figurinha, faz com que cada edição que passe se torne melhor que a anterior.

E: Existe uma orientação pra produção de arquivos multimidiáticos, em formatos diferentes? E quais são os critérios que você utiliza pra escolher? 
EA: Eu acho que vai muito do feeling mesmo, porque nenhum de nós aqui fez uma faculdade que já tinha altas cadeiras ensinando o que que combinava nessa parte de fazer jornalístico pra esse tipo de mídia, o meu curso era pra impresso. Então a gente pensa muito na gente, no que a gente gostaria de ver, assim, "eu prefiro isso aqui no vídeo, fica mais interessante do que num áudio", nem sempre a gente acerta, a gente também erra, aprende com os próprios erros, né. E aí, por isso também que é importante a questão da organização, porque dá mais tempo de você produzir, "isso aqui não ficou legal desse jeito, vamos refazer", como a Marina falou, o que vem no vídeo fica interessante não vim no escrito, o que tiver no vídeo não ficar repetindo na parte escrita, esta questão da organização das matérias pra gente pode ver direitinho uma parte do conteúdo via impressa, outra parte é mais interessante ser áudio, outra parte ser visualmente, acho que é na tentativa mesmo.

E: Existe alguma fonte que é mais apropriada ou não para o suporte?

EA: Acaba que sim, porque assim, tem gente que tem dificuldade de falar, tem gente que a gente vai entrevistar pro vídeo e a pessoa trava, mas é mais por conta disso, não porque a pessoa não é uma boa fonte, sabe, mas mais por isso mesmo.

E: Você utiliza alguma base de dados para a produção da matéria?

T: Não, assim, a gente vai pesquisando dependendo do tema da matéria.

E: Vocês acabam utilizando as outras edições de alguma forma para produzir conteúdos?

EA: A gente evita fazer tema que já saiu, a gente olha as edições anteriores pra não repetir tema, e algo que já saiu a gente pode dar uma renovada, uma revigorada.

E: Você tem algum planejamento pra pensar na arquitetura da informação quando você vai organizar o seu conteúdo? "Ah meu vídeo vai na frente”, ou não, "vou colocar um áudio".

EA: A gente troca muita informação com as meninas porque eu acho que elas tem mais propriedade pra entender esse tipo de coisa.

E: Você utiliza algum critério para escolha do local de link? Aí eu queria que você dissesse como que você escolhe isso.

EA: Acho que mais também como vai ser formada a página, essa primeira página tem muito texto, ficaria bacana um link puxando aqui, às vezes pra não ficar muito link na primeira página a gente puxa pra segunda, às vezes a gente tem muito scrow aí a gente deixa pra segunda página, tudo a gente discute.

E: Você tem alguma preocupação com a interatividade no conteúdo que você vai produzir? 
EA: Sim, às vezes acontece de algumas matérias não terem tanta interação e isso incomoda um pouco, né, até porque o conteúdo da gente é diária, então a gente procura, faz uma linha do tempo, nem toda matéria tem vídeo, a gente procura correr atrás disso por conta do veículo ter esse apelo.

E: E você está dentro de uma redação que está próxima de outros veículos, né, você acha que isso acaba impactando de alguma forma no seu trabalho? E se sim, de que jeito?

EA: Eu acho assim, por a gente trabalhar com essa questão de integração a gente acaba sendo mais aberto a essa realidade, mas não que as outras pessoas sejam fechadas porque elas querem, mas assim, agora, a partir da próxima semana a gente vai sair daqui e vai ficar lá dentro, então eu acho que isso vai colaborar pra eles entenderem mais o que acontece aqui dentro, entendeu? E seria interessante que pessoas de fora, que não são do Plus, fizessem, colaborassem esporadicamente com a gente pra entender que isso aqui é o futuro, sabe.

E: Na sua experiência profissional você acredita que tem alguma transformação na rotina de produção que vai, não sei se você já viu em algum outro suporte isso, mas que há uma alteração no processo de produção?

EA: Sim, às vezes eu também escrevo pro impresso, tenho coluna no impresso, a gente se sente limitado no impresso, porque você tem uma forma $\mathrm{X}$ e um tamanho e não pode passar daquilo, e aqui, lógico, como as meninas falaram a gente tenta fazer com que o texto seja uma página e meia e tal, mas mesmo assim a gente pode dar asas à imaginação, pode criar uma linha do tempo, pode colocar o resto do conteúdo em vídeo, você pode dar asas à sua imaginação. É mais desafiador porque você tem mais pra onde ir do que lá, e eu acho que é legal isso. 